UNIVERSIDADE DE SÃO PAULO

FACULDADE DE FILOSOFIA, LETRAS E CIÊNCIAS HUMANAS

DEPARTAMENTO DE ANTROPOLOGIA

PROGRAMA DE PÓS-GRADUAÇÃO EM ANTROPOLOGIA SOCIAL

VALÉRIA ALVES DE SOUZA

\title{
Para o Público ou para o Privado? \\ Relações raciais, educacionais e institucionais (in)audíveis no município de Laranjeiras (SE). Um estudo de caso
}

VERSÃO CORRIGIDA 
UNIVERSIDADE DE SÃO PAULO

FACULDADE DE FILOSOFIA, LETRAS E CIÊNCIAS HUMANAS

DEPARTAMENTO DE ANTROPOLOGIA

PROGRAMA DE PÓS-GRADUAÇÃO EM ANTROPOLOGIA SOCIAL

\title{
Para o Público ou para o Privado? Relações raciais, educacionais e institucionais (in)audíveis no município de Laranjeiras (SE). Um estudo de caso
}

\begin{abstract}
Valéria Alves de Souza
Tese apresentada ao Programa de PósGraduação em Antropologia Social do Departamento de Antropologia da Faculdade de Filosofia, Letras e Ciências Humanas da Universidade de São Paulo para a obtenção do título de Doutora em Antropologia, sob orientação da Prof. ${ }^{a}$ Livre Docente Laura Moutinho
\end{abstract}

VERSÃO CORRIGIDA 
Autorizo a reprodução e divulgação total ou parcial deste trabalho, por qualquer meio convencional ou eletrônico, para fins de estudo e pesquisa, desde que citada a fonte.

Catalogação na publicação

Serviço de Biblioteca e documentação

Faculdade de Filosofia, Letras e Ciências Humanas da Universidade de São Paulo

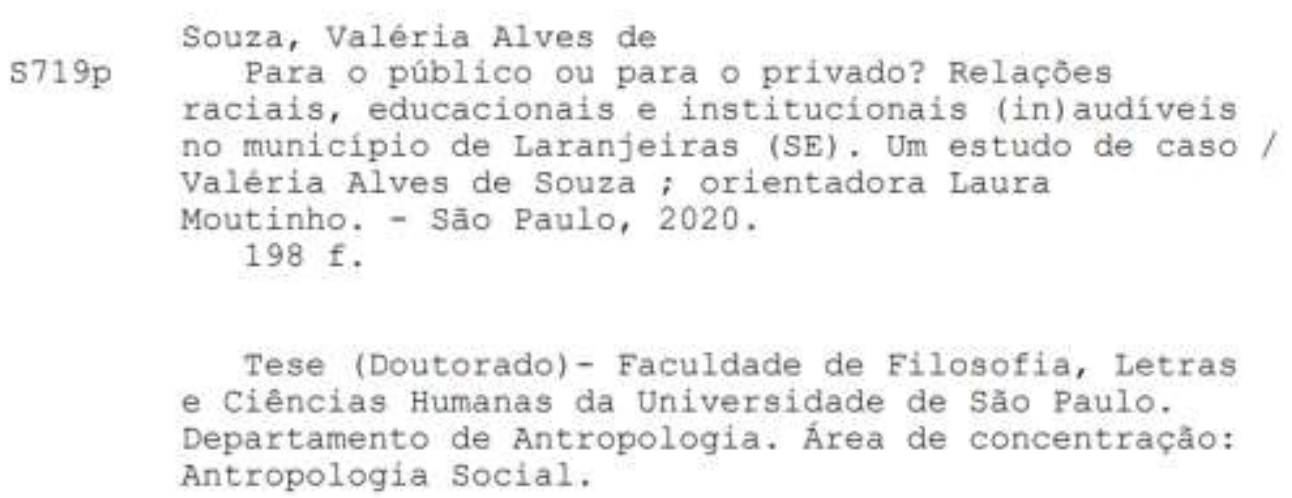

1. ANTROPOLOGIA POLITICA. 2. EDUCAÇÃO. 3. PARCERIA PÚBLICO-PRIVADA. 4. RELAÇÖSS ETNICAS E RACIAIS. 5. ANTROPOLOGIA EDUCACIONAL. I. Moutinho, Laura, orient. II. Titulo. 


\title{
ENTREGA DO EXEMPLAR CORRIGIDO DA DISSERTAÇÃO/TESE
}

\section{Termo de Ciência e Concordância do (a) orientador (a)}

\author{
Nome do (a) aluno (a): Valéria Alves de Souza \\ Data da defesa: 27/03/2020 \\ Nome do Prof. (a) orientador (a): Laura Moutinho
}

Nos termos da legislação vigente, declaro ESTAR CIENTE do conteúdo deste EXEMPLAR CORRIGIDO elaborado em atenção às sugestões dos membros da comissão Julgadora na sessão de defesa do trabalho, manifestando-me plenamente favorável ao seu encaminhamento e publicação no Portal Digital de Teses da USP.

São Paulo, 20/06/2020

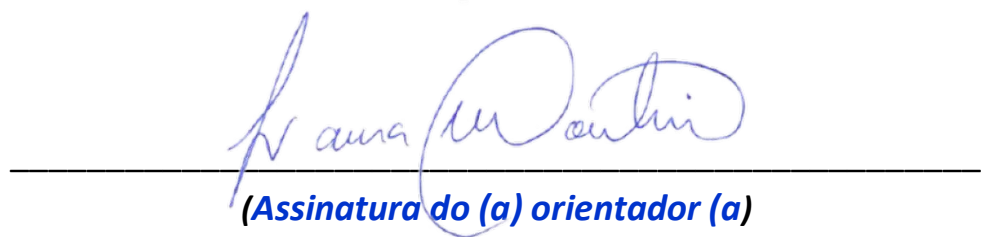


SOUZA, Valéria Alves. Para o Público ou para o Privado? Relações raciais, educacionais e institucionais (in)audíveis no município de Laranjeiras (SE). Um estudo de caso. Tese apresentada à Faculdade de Filosofia, Letras e Ciências Humanas da Universidade de São Paulo para obtenção do título de Doutora em Antropologia.

Aprovada em: 27/03/2020

\section{Banca Examinadora}

$\operatorname{Prof}(\mathrm{a}) . \operatorname{Dr}(\mathrm{a})$.

Instituição:

Julgamento: Assinatura:

$\operatorname{Prof}(\mathrm{a}) . \operatorname{Dr}(\mathrm{a})$.

Instituição:

Julgamento: Assinatura:

Prof(a). Dr(a).

Instituição:

Julgamento: Assinatura: 
De todo o amor que eu tenho

Metade foi tu que me deu Salvando minh'alma da vida Sorrindo e fazendo o meu eu

Se queres partir ir embora

Me olha da onde estiver Que eu vou te mostrar que eu tô pronta

Me colha madura do pé

Salve, salve essa nega Que axé ela tem

Te carrego no colo e te dou minha mão Minha vida depende só do teu encanto

Cida pode ir tranquila

Teu rebanho tá pronto

Teu olho que brilha e não para

Tuas mãos de fazer tudo e até

A vida que chamo de minha

Neguinha, te encontro na fé

Me mostre um caminho agora

Um jeito de estar sem você

$O$ apego não quer ir embora

Diaxo, ele tem que querer

Salve, salve essa nega

Que axé ela tem

Te carrego no colo e te dou minha mão

Minha vida depende só do teu encanto

Cida pode ir tranquila

Teu rebanho tá pronto

- Maria Gadú

Dedico esta tese a minha Amada e Guerreira Mãe

Maria Aparecida Alves de Souza

in memorian - 1951-2019 
C. 


\section{Agradecimentos}

Agradeço e sempre vou agradecer minha mãe Maria Aparecida Alves de Souza, que foi morar com os nossos ancestrais em 2019. Antes de partir, criou e encaminhou sete filhas, cuidou de todas nós e do seu marido, meu pai. Ela era linda, poderosa, altiva e mandona. Todes adoravam a sua companhia. Mãe, eu te amo e vou te amar por toda minha existência! Agradeço, também, meu pai Justino Alves de Souza, homem trabalhador que, por muitas vezes deixou de se alimentar, para que não faltasse comida nos nossos pratos. Obrigada paizinho!

Minhas irmãs, amadas, terríveis, divertidas brigonas e lindas. Meu muito obrigado por estarem comigo nessa caminhada que não foi fácil e por ter me dado sobrinhes lindes!

Agradeço os dez anos que convivi com a Laura, minha orientadora que esteve ao meu lado nos momentos das alegrias e das crises durante este processo de produção. Ela é ótima, inteligente, divertida, carinhosa e preocupa. Parte da minha trajetória de pesquisa devo à sua dedicação.

Agradeço meus colegas de orientação, que juntos vivemos muitas coisas interessante e intensas. Laís, Denise, Pedro, Milena, Thaís, Bruna, Alessandra, Márcio e todes que me auxiliaram lendo e comentando meus textos. Agradeço todo o meu grupo de orientação pelas leituras, risadas, e pelo partilhamento das angústias.

Agradeço minhas amigas do coração que me acompanharam nesta jornada. Pelos afetos, companheirismo e por todas as trocas.

Agradeço o meu Departamento pelo trabalho de todes. Esta tese foi possível graças aos recursos de bolsa de doutorado Capes; Coordenação de Aperfeiçoamento de Pessoal de Nível Superior- Brasil (CAPES) - Código de Financiamento 001.

Agradeço as e os professores que aceitaram avaliar este trabalho: Flávia Rios, Heloísa Almeida, Paulo Neves, Silvana Nascimento, Léa Tosold e Uvanderson Silva.

Agradeço os Movimentos Sociais e Coletivos Negros que me formaram na militância e que se empenham cotidianamente em denunciar as desigualdades, o racismo, sexismo, a transfobia. Movimentos que se dedicam a anunciar o respeito às diferenças. 
SOUZA, Valéria Alves. Para o Público ou para o Privado? Relações raciais, educacionais e institucionais (in)audíveis no município de Laranjeiras (SE). Um estudo de caso. Tese (Doutorado) - Faculdade de Filosofia, Letras e Ciências Humanas, Universidade de São Paulo, 2020.

RESUMO: O objetivo desta tese foi o de perscrutar as implicações que a parceria público-privada proporciona ao implementar uma política pública para a educação no município de Laranjeiras (SE). A tese de foi escrita em um contexto de expansão das determinações de grandes empresas privadas pautando projetos para a educação básica e pública no Brasil. As parcerias público-privadas vêm se anunciando, como uma forma de colonização nas formas de gestar a educação básica na ponta, imprimindo programas e projetos com viesses da lógica empresarial. Nesta tese a perspectiva da gestão escolar do município, as tensões e ambiguidades foram eleitas para conduzir as análises.

Esta pesquisa percorreu três abordagens ou campos distintos de análise: o da educação, visto que o foco é a implementação de um projeto pedagógico no sistema educacional de Laranjeiras e, como foi já foi dito, o alicerce dessa etnografia será a gestão escolar do município. O campo das políticas públicas também será acionado, pois são instituições públicas e privadas que estão articulando e promovendo este processo, e por fim, a arena das relações raciais já que a proposta é considerar as especificidades, históricas, raciais e sócio/culturais do município, mencionadas anteriormente.

Para tanto, perspectiva da interseccionalidade, foi privilegiada. Outra proposta foi fazer uma articulação ou a intersecção dos campos das relações raciais, da antropologia política e fortalecer o campo da antropologia da educação.

Na contemporaneidade o grande desafio da educação é a construção de um sistema educacional que rompa com os modelos homogeneizantes posto no passado, que negam a diversidade humana propiciando à exclusão de diversos segmentos sociais que não se encaixam num modelo único de educação. Na antropologia da educação, o debate contemporâneo está centrado nas questões que envolvem as noções de diversidade e diferença nas políticas públicas. Este debate é importante, pois nos possibilita analisar o quanto essas noções foram utilizadas ou não, pensadas ou não nessa política pública implementada na Secretaria Municipal de Laranjeiras sob título de parceria e o que isso pode afetar positiva e/ou negativamente, ou mesmo não afetar no cotidiano escolar do município.

PALAVRAS-CHAVE: Marcadores sociais da diferença; raça; gênero; região; parceria público-privada; educação, Laranjeiras. 
SOUZA, Valéria Alves. For the public or the private? (In)audible Institutional and Colonial Racial Relations in the municipality of Laranjeiras (SE) A case study. Thesis (PhD in Social Anthropology) - Faculdade de Filosofia, Letras e Ciências Humanas, Universidade de São Paulo, 2020.

ABSTRACT: The goal of this thesis is to examine the implications that the public-private partnership has in the implementing process of a public policy for education in the municipality of Laranjeiras (SE). The thesis was written in a context of expansion of the determinations of large private companies guiding projects for basic and public education in Brazil. Public-private partnerships have been announcing themselves as a form of colonization in the forms of managing basic education at the top, printing programs and projects based on business logic. In this thesis the perspective of school management of the municipality, the tensions and ambiguities were elected to conduct the analysis.

This research covered three different approaches or fields of analysis: education, since the focus is the implementation of a pedagogical project in the Laranjeiras educational system and, as has been said, the foundation of this ethnography will be the school management of the municipality. The field of public policies will also be triggered, as it is public and private institutions that are articulating and promoting this process, and finally, the arena of race relations since the proposal is to consider the historical, racial and socio/cultural specificities of the municipality, mentioned earlier.

Therefore, the perspective of intersectionality was privileged. The proposal was to articulate or intersect the fields of race relations, political anthropology and strengthen the field of anthropology of education.

In contemporary times the great challenge of education is the construction of an educational system that breaks with the homogenizing models put in the past, which deny human diversity, leading to the exclusion of various social segments that do not fit into a single model of education. In the anthropology of education, the contemporary debate is centered on issues involving the notions of diversity and difference in public policy. This debate is important because it allows us to analyze how much these notions were used or not, thought or not in this public policy implemented in the Municipal Secretariat of Laranjeiras under the title of partnership and what this can positively and/or negatively affect, or even not affect in the daily school life of the municipality.

KEYWORDS: Documental markers of difference; race; gender; region; public-private partnerships; education; Laranjeiras. 


\section{Lista de Siglas}

AVA

BID

BNCC

CAFOD

CEO

CUT

DAC

DFP

EAD

FHC

FNDE

IC

IDEB

IDH

INEP

IPHAN

ISER

LDB

LRF

NUMAS

ONG

ONU

OP

PDE

PNE

PPP

SE

SP

TICS

TPE

UNIT

USP
Ambiente Virtual de Aprendizagem

Banco Interamericano de Desenvolvimento

Base Nacional Comum Curricular

Catholic Agency for Overseas Development

Chief Executive Officer

Central Única dos Trabalhadores

Grupo de Assistência ao Desenvolvimento

Departamento para a Cooperação Técnica

Educação à Distância

Fernando Henrique Cardoso

Fundo Nacional para o Desenvolvimento da Educação

Instituto Camaleão

Índice de Desenvolvimento da Educação Básica

Índice de Desenvolvimento Humano

Instituto Nacional de Estudos e Pesquisas

Instituto do Patrimônio Histórico e Artístico Nacional

Instituto de Estudos da Religião

Lei de Diretrizes e Bases da Educação Nacional

Lei de Responsabilidade Fiscal

Núcleo dos Marcadores Sociais das Diferenças

Organização Não-governamental

Organização das Nações Unidas

Orçamento Participativo

Plano de Desenvolvimento da Educação

Plano Nacional de Educação

Parceria Público-Privada

Sergipe

São Paulo

Tecnologias da Informação e Comunicação

Todos Pela Educação

Universidade Tiradentes

Universidade de São Paulo 


\section{Sumário}

APRESENTAÇÃO

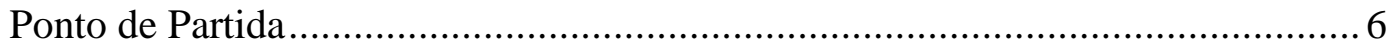

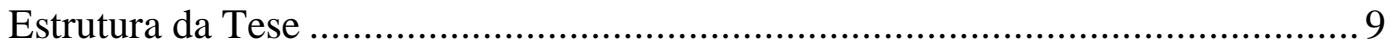

PRELÚDIO. TEMPOS E TEMPORALIDADES: UM AVANÇO, UM RECUO .............................. 11

CAPÍTUlO 1. PRETA E CABOCLA: LARANJEIRAS, TERRA DE LARANJAIS, QUILOMBOS E DAS

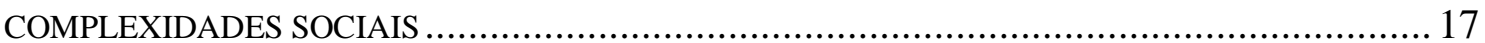

1.1. Daqui Pra Lá, De Lá Praqui: olhares etnográficos, histórias consideráveis... 21

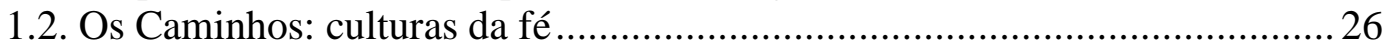

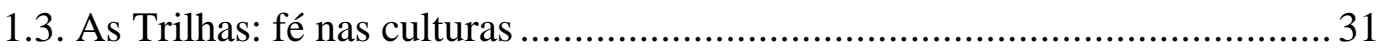

1.4. Laranjeira: "uma prisão a céu aberto"? O que ouvir e como contar ...............6 60

CAPÍTUlo 2. MEDIANDO CONVENIÊNCIAS, PAUTANDO INCONSISTÊNCIAS: RAÇA, CULTURA E EDUCAÇÃO NA GESTÃO ESCOLAR EM LARANJEIRAS

2.1. Mulher, Raça, Classe e Carreira: o que se faz, o que se sonha, o que se tem! 88

2.2. A Rota dos Povoados: pessoas, tempos, caminhos e paisagens .................... 97

2.3. O Cotidiano: embates, cores e identidade ............................................... 103

2.4. Coordenadas e Estratégias de Fora para Dentro: a educação no olho da

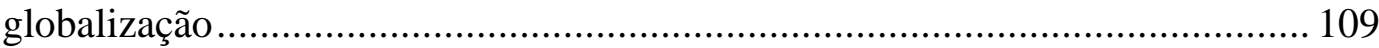

CAPÍtUlo 3. PARA O PÚBlico OU PARA O PRIVAdO? ARRANJOS E DESCOMPASSOS NA

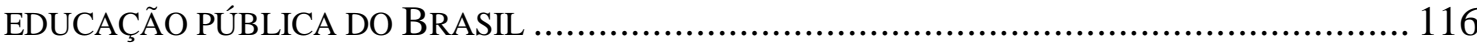

3.1. Juntos pela Educação - pelos Pobres e Desvalidos: um projeto de nação

determinado pela classe empresarial......................................................... 118

3.2. Saberes Técnico-Burocráticos: o avanço e as contradições das ONGs no

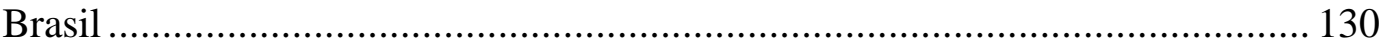

3.3. O Campo: burocratas de rua? O que dizem e o que pensam ....................... 138

3.4. A Parceria e suas Múltiplas Dimensões ................................................... 142

3.5. O Público e o Privado: interesses e politicagem na toada dos privilégios ... 147

CAPÍTUlO 4. UM PROJETO DE NAÇÃO: PERSPECTIVAS NEOCOLONIAIS E AS PARCERIAS

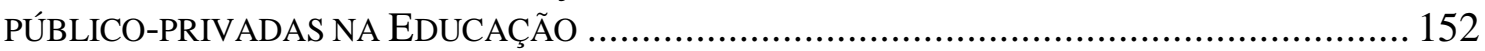

4.1. A Interseccionalidade como Tecnologia de Linguagem e Enfrentamento: um

chão firme e forte...................................................................................... 154

4.2. Identidade e Desigualdade, entre Sociologia, Antropologia e os Debates sobre

Colonialidade e Pós-Colonialismo: um percurso entre autores......................... 160

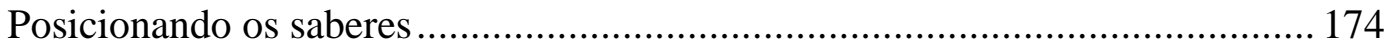

4.3. Neocolonização: esquemas de interferências e as possibilidades de efetivação

4.4. Neocolonialismo e Educação: nomear é preciso, mas nem sempre é visível. O

cotidiano escolar em Laranjeiras ...................................................................... 184

PONTO DE CHEGADA. CONSIDERAÇÕES FINAIS ..................................................... 188

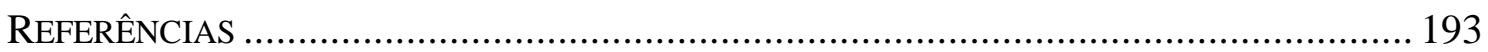




\section{Apresentação}

A palavra Encruzilhada diz muito sobre os processos de pesquisa e escrita desta tese. Ela se apresentou em diversos momentos interseccionando minha vida pessoal, acadêmica e profissional. É possível projetar várias imagens de uma Encruzilhada, a que trago tem essa: um ponto central, que nas suas laterais tem três ou quatro caminhos e se faz necessário escolher um para seguir. Entretanto, é possível voltar atrás, escolher outro e mais outros. A boa sorte está na oportunidade de juntar as experiências adquiridas em cada um deles e construir um novo caminho, uma nova estrada, uma nova trilha e seguir.

Foi assim desde 2015, quando da minha entrada no doutorado. A proposta inicial de minha pesquisa de doutorado era analisar o Programa Cultura Viva com foco nos Pontos de Cultura, uma análise já iniciada em minha dissertação de mestrado: Os Tambores das "Yabás": raça, gênero, sexualidade e cultura no Bloco Afro Ilú Obá De Min (Souza, 2014). No último capítulo da dissertação, "Cultura e Políticas: articulações intermitentes", analisei como o Ilú Obá De Min acionava o resgate da cultura e do sentimento de pertença racial como recursos para afirmar sua identidade no momento de pleitear, negociar, políticas culturais e financiamentos. A identidade racial/cultural passou a ser assumida como argumento político. A partir do mestrado, escolhi um caminho, o de pesquisar as políticas públicas para cultura, dando sequência aos temas da dissertação. Um caminho bom, potente, bem articulado com o campo, com as interlocutoras e interlocutores e com as bibliografias essenciais. Minha pesquisa com o Bloco Afro Ilú Oba De Min teve início em 2008 durante a minha primeira iniciação científica sob orientação da Professora Laura Moutinho, junto ao Departamento de Antropologia/USP. A pesquisa de Iniciação Cientifica contou com bolsa PIBIC/CNPq.

Foram oito anos estudando movimentos culturais negros, políticas de inclusão da arte negra, carnaval e blocos afros. Nessa trilha, o caminho parecia não ser tão árduo e mais seguro. No entanto, forças externas à pesquisa, me levaram-me a uma nova Encruzilhada.

Assim, os objetivos da pesquisa de doutorado eram analisar, por meio da implementação e difusão dos Pontos de Cultura, como estavam sendo construídos os diálogos, interações e articulações entre os Ponteiros; de que forma os Ponteiros ${ }^{1}$ e o poder público articulavam e operacionalizavam a cultura como artefato das políticas

\footnotetext{
${ }^{1}$ São chamados de Ponteiros as lideranças dos grupos culturais que recebem financiamento do Programa Pontos de Cultura.
} 
públicas, com demarcações próprias e operativas; como a identidade cultural, a diversidade e a etnicidade estavam sendo construídas e reelaboradas; como os grupos culturais estavam reelaborando suas origens históricas; e como a identidade racial e cultural estava sendo construída/reconstruída.

Em meados de 2016, quando eu começaria a realizar as atividades de pesquisa de campo, houve uma reviravolta no cenário político nacional: é de conhecimento público que a presidenta em exercício Dilma Rousseff sofreu um processo de impeachment e todo o sistema político do Brasil ficou paralisado e na expectativa do que iria acontecer.

Com isso, as Redes e Comissões Nacionais de Pontos de Cultura entraram em um processo de suspensão, pois ninguém sabia quais seriam os próximos passos e que tratamento o novo presidente daria para essas Redes e Comissões.

Uma das primeiras ações do novo presidente foi propor uma reforma ministerial e, entre as alterações, o Ministério da Cultura (MinC) foi transformado em uma Secretaria e agregado ao Ministério da Educação, passando a se chamar Ministério da Educação e Cultura. Assim, a pasta da Cultura perderia a sua exclusividade. Este decreto presidencial foi publicado no Diário Oficial da União já em 12 de maio de 2016.

A publicação deste decreto causou indignação geral dos grupos, coletivos, redes, comissões e artistas autônomos de diferentes seguimentos da cultura. A possibilidade real da extinção de diversos programas e a diminuição de incentivos à cultura, fez com que, nas semanas seguintes à publicação, houvesse diversos protestos por todo o país e ocupações a órgãos públicos ligados à cultura, como, os prédios da Fundação Nacional da Arte (FUNARTE).

O acontecido foi noticiado em diversas mídias, produzindo forte pressão política contra o então presidente em exercício. Alguns parlamentares, diante dessa miríade de reações e também por pressão popular, argumentaram com o novo presidente sobre a necessidade de recriação do MinC. Tratou-se de uma negociação difícil e demorada, pois, para o presidente, recuar nas suas decisões representava um enfraquecimento político.

Os atos e protestos se intensificaram por todo o país e, finalmente, em outubro de 2016, foi recriado o Ministério da Cultura por meio da Medida Provisória-728/2016, mais tarde transformada em lei.

Com todos esses processos e com a incerteza se eu conseguiria manter a mesma pesquisa, diante dessa Encruzilhada, eu e minha orientadora, após longas conversas e reflexões, decidimos escolher outro caminho para a pesquisa e nos arriscar por novas trilhas. 
Nos últimos dez anos da minha vida profissional, na formação do meu curriculum vitae, somei experiências na área educacional. Antes e durante o meu mestrado (que realizei sem acesso a bolsa) trabalhei em algumas instituições que tinham a educação pública como seu principal aporte. Fui me tornando, ao longo do tempo, uma "especialista", observadora e questionadora sobre as formas que as instituições sem fins lucrativos operacionalizavam a educação: de um lado, como algo essencial para provocar o pensamento crítico na população, a fim de transformar suas realidades; de outro, as inspirações, formulações e projetos dessas instituições estavam muito distantes das realidades das escolas públicas brasileiras. Entretanto, nessas instituições, que alguns chamam de "instituições de esquerda", havia uma preocupação com os Direitos Humanos e Fundamentais, um respeito pelas diversidades e a busca pela equidade.

Em 2017, fui convidada a acompanhar a implementação de um projeto de formação e desenvolvimento das competências profissionais da gestão educacional e escolar da cidade de Laranjeiras em Sergipe. Esse projeto foi formulado por uma instituição financiada por um dos maiores grupos empresariais do Brasil e da América Latina, e constituía-se numa das chamadas PPP, as parcerias público-privadas.

O acompanhamento da implementação desse projeto suscitou-me muitas indagações sobre os processos e procedimentos que as instituições públicas e privadas se acoplam num sistema de parceria público-privada e manejam pautas para políticas públicas sem nenhuma consulta ou interação com os possíveis beneficiários destas, e sem levar em consideração as especificidades históricas e culturais das localidades de implementação.

A partir de então, começamos a pensar nesse novo caminho de pesquisa, consideramos minhas vivências no acompanhamento da implementação do projeto, dos relatos e impressões em meu relatório de trabalho, das conversas informais que tive ao longo de um ano com profissionais da educação de Laranjeiras.

Diante disso, decidi pesquisar as intervenções de projetos das parcerias públicoprivadas na educação, especificamente, aquele que acompanhei no município de Laranjeiras. Minha intenção inicial era saber a quem as parcerias, de fato, atendiam: se o público, ou seja, os setores públicos e a população, ou se somente os propósitos da iniciativa privada.

No momento do meu exame de qualificação, em 2017, apresentei para a banca um relatório que anunciava os propósitos do novo projeto. A banca acolheu a proposta e me 
solicitou um projeto detalhado sobre os procedimentos que envolveriam a nova pesquisa. Assim o fiz e iniciei formalmente minha pesquisa de campo em janeiro de 2018.

Outras Encruzilhadas se fizeram presentes neste percurso. A primeira e mais delicada delas, que percorreu toda a escrita da tese, foi o anonimato, pois minha inserção inicial no campo, minhas anotações e registros foram realizados, como assinalei, durante meu acompanhamento nas atividades propostas pelo projeto. Encontrei a segunda Encruzilhada na escolha da a metodologia de perscrutar esse campo por meio da gestão escolar de Laranjeiras. A empresa que financiou o projeto não foi incluída nesse desenho, visto que seria preciso enfrentar um longo processo burocrático para conseguir entrevistas ou algum posicionamento, e com poucas chances de conseguir.

Minhas inclinações metodológicas e também analíticas e políticas, desde o início, buscaram afirmar a perspectiva das gestoras, que são elas, como veremos, as principais agentes desse projeto, como receptoras e como responsáveis pela sua implementação.

Laranjeiras, então, passou a ser o locus central da pesquisa. Trata-se de um município com duas grandes comunidades quilombolas e a população preta e parda é de 62,8\%. Em 2016, a população total era de 29.418 habitantes. Segundo o Censo de 2010, o índice de pobreza do município era de $61,56 \%$, o Índice de Desenvolvimento Humano (IDH) de 0,646 e o Índice de Desenvolvimento da Educação Básica (IDEB) é de 2,5\%. Esses são valores muito baixos se comparados com as médias do Estado de Sergipe e com a média nacional. Marcada por esses índices, Laranjeiras abriga em seu território, há mais de 30 anos, uma grande indústria de cimentos, que impacta diretamente as relações ambientais do município, bem como as relações de trabalho e emprego e as relações raciais.

Neste sentido, esta tese passou a se ancorar na seguinte hipótese e objetivos: na atualidade estão cada vez mais frequentes as parcerias entre as instituições públicas e privadas em diversos setores, inclusive no educacional, nomeadas de parcerias públicoprivadas (PPP) (SANTANA, 2006). Em Laranjeiras, município do estado de Sergipe, apesar do processo de escravidão ser reconhecido e rememorado pelos agentes públicos (LIMA, 2010), as relações entre os habitantes e as parcerias público-privadas são conflituosas, e de certa forma, inaudíveis, assim como as relações raciais, políticas e de poder. A intervenção de um projeto construído e implementado por uma instituição vinculada a grandes grupos empresariais na educação do município, sem consulta pública e prévia e sem planejamento coletivo, pode contribuir para o apagamento de questões essenciais que atravessam a educação e vida dos laranjeirenses, silenciando os conflitos 
e ocasionando prejuízos para a população negra, branca e não negra, tornando mais difícil o diálogo na busca de soluções para uma vivência equânime e saudável.

O objetivo desta tese foi analisar se a intervenção de projetos da parceria públicoprivada na educação pública e básica de Laranjeiras está edificando um novo modelo de colonização pela educação. Analisar, por meio do trabalho de campo, se existe a possibilidade de realização deste empreendimento. 


\section{Ponto de Partida}

Meu ponto de partida para a construção desta tese foi reler e sistematizar os relatórios e anotações que eu havia feito durante o ano de 2017, quando conheci o município de Laranjeiras e lá acompanhei a implementação de um projeto de formação para a gestão educacional (secretário e técnicas da Secretaria de Educação) e gestão escolar (diretoras e coordenadoras pedagógicas).

Além dos relatórios de acompanhamento, minha vivência com as gestoras do município se tornou parte desta pesquisa. Me tornei próxima de algumas delas, frequentei suas casas, conheci as famílias, fui informada sobre as questões políticas e sociais que ocorriam naquele momento no município, e tive a grata oportunidade de conhecer mais profundamente a realidade local.

Minha experiência de trabalho com as gestoras escolares e essa vivência no âmbito mais íntimo com elas, minha circulação no meio político e institucional, as conversas, as saídas e, mais tarde, as entrevistas e todo o trabalho de campo, trouxeram-me uma questão preciosa e antiga para a antropologia: tempo e temporalidade, usadas por mim no plural, ou seja, tempos e temporalidades.

As tecnologias que nos conferem, como participantes do presente, competentes, dinâmicas, antenadas, construtoras do futuro, inserção no sistema global, não encontram solo consistente em Laranjeiras. A internet é precária nos órgãos públicos, $80 \%$ da população não tem internet em casa. Não há um investimento concreto e potente dos sistemas de telefonia. O uso de e-mails não era uma prática regular, até mesmo para as administradoras das 17 escolas do município, entretanto, as redes sociais WhatsApp e Facebook eram usadas como forma de comunicação, e estes configuravam-se como os principais sistemas que fazem com que essa população se veja participante da esfera global.

Não quero, de maneira nenhuma, tratar esse fato como um atraso do município perante às outras regiões do Brasil e do mundo. A intenção aqui, e em toda a escrita, é, justamente, apontar um desafio que está posto desde o Brasil colônia: um Brasil que se coloca como participante do sistema capitalista, da globalização, do avanço das tecnologias, mas que não cria condições reais para que toda a população participe.

O progresso que a as elites intelectuais, econômicas e culturais, impõem para o país, não confere com a realidade. Existe aí uma inadequação. O princípio burguês: as cópias estrangeiras, imposições culturais, gastronômicas, da moda, de estilo de vida, 
padrões tecnológicos, não refletem a realidade do país. Repito, essa relação é antiga, ser/estar "nacional por subtração" faz muito sentido ainda, principalmente no meu campo de pesquisa.

Este foi meu ponto de partida e, a partir de então, fui buscar bibliografias que me ajudassem a compreender melhor essas questões e verificar se, de fato, o que eu pensava estava condizente. Conversei com algumas pessoas que pensam e estudam o Brasil e toda a lógica de constituição da nação brasileira, revi estudos que tratam da formação do Brasil e da constituição de uma identidade nacional.

Nessa trajetória, foi essencial pensar nas relações raciais de maneira interseccional no contexto de Laranjeiras.É uma cidade histórica negra, tombada como patrimônio nacional. Lá está o primeiro museu afro-brasileiro e se trata de um dos poucos municípios históricos que, durante o sistema escravista, construiu três igrejas: a dos brancos, dos pretos e dos pardos.

Na educação, Laranjeiras tem como marco e símbolo a primeira professora negra que funda a primeira escola em funcionamento até hoje. Suas duas maiores manifestações culturais, celebradas todos os anos, têm como base a arte, a música, a literatura, a dança, advindas do período colonial. A maioria delas dá conta de recordar e teatralizar os conflitos entre pretos e indígenas à época. As construções, o rio que corta a cidade, as manifestações religiosas, as pessoas, as relações de poder, as desigualdades, as precariedades, o desemprego em Laranjeiras, todos esses elementos têm cor, como veremos no decorrer dos capítulos.

As pesquisas mostram que a população negra em todo o Brasil vive numa situação de desigualdade gritante. Quem lê esta tese pode perguntar: então, o que te chamou atenção? Respondo: além do fato de ser um município que não tem um apartheid regional, ou seja, as pessoas circulam nos mesmos espaços e, com isso, as desigualdades e conflitos ficam mais visíveis, quem administra 16 das 17 as escolas do município são gestoras, mulheres negras, diretoras e coordenadoras pedagógicas. Esta tese é alinhavada a partir do ponto de vista e das experiências dessas mulheres.

Entretanto, embora sejam elas que administram as escolas, a educação do município é gerida por uma equipe majoritariamente branca e munícipe da capital, Aracaju. Além disso, essas gestoras estão submetidas a projetos educacionais nos quais elas não são chamadas para planejar e ajustar de acordo com a realidade local. São apenas executoras e/ou participantes compulsórias. 
Desse modo, a linha de pesquisa sobre ou dos "Marcadores Sociais da Diferença" tem aqui lugar privilegiado. Raça, gênero, região e classe circundam este trabalho, que investiga suas articulações no campo da educação.

Se este é um estudo de caso, no entanto, vamos ver ao longo dos capítulos como esse caso não é isolado, e está cada vez mais recorrente. Portanto, acredito ser necessário olhar com atenção e traçar linhas de interpretação, visto que a interferência e o tipo de intencionalidade de alguns projetos no sistema educacional do país prevê a mudança de relações, comportamentos e sistemas de pensamento, além de contribuir para que as desigualdades permaneçam, e que o presente mantenha-se no passado.

Os procedimentos metodológicos foram escolhidos em face ao exposto. Para garantir o sigilo das entrevistadas, usei o recurso do codinome, atribuindo-lhes os pseudônimos daquelas consideradas pelos movimentos sociais e pelo feminismo negro heroínas negras do Brasil. Para garantir o anonimato das empresas e instituições, principalmente no capítulo três, fiz uso de recursos narrativos que unem ficção e realidade. Em alguns momentos, os nomes de algumas das instituições desse campo tornam-se expressos, conforme eles estão presentes em bibliografias publicadas - nos demais casos, não. Sigamos. 


\section{Estrutura da Tese}

Esta tese divide-se em quatro capítulos, que percorrem o conjunto de questões que sinalizei nesta Apresentação. Descrevo cada um deles.

\section{Capítulo 1. Preta e Cabocla: Laranjeiras, terra de laranjais, quilombos e das complexidades sociais}

A intenção desse capítulo foi apresentar para a leitora e para o leitor o município de Laranjeiras. Embora eu tenha encontrado muitos trabalhos sobre o município na antropologia, na história e nas artes, observei que o Laranjeiras é desconhecida por muitas pesquisadoras destas áreas e pela militância negra sudestina. Adianto que não se trata apenas de uma apresentação histórica, tem uma intencionalidade, qual seja: conduzir a escrita de modo a exaltar as questões deste trabalho. Além disso, minha entrada no campo como pesquisadora e como profissional da educação, as relações que eu estabeleci com as minhas interlocutoras, e todo o trabalho de campo também fizeram parte deste capítulo.

\section{Capítulo 2. Mediando Conveniências, Pautando Inconsistências: raça, cultura e educação na gestão escolar em Laranjeiras}

Este capítulo se foca no tema da gestão escolar e procura perscrutar as implicações das parcerias público-privadas na educação, tendo como campo etnográfico o município de Laranjeiras. Sigo as experiências, relatos e reflexões das gestoras, diretoras e coordenadoras pedagógicas, compondo um olhar etnográfico a partir do meu acompanhamento nas atividades educacionais do município.

\section{Capítulo 3. Para o Público ou para o Privado? Arranjos e descompassos na educação pública do Brasil}

O capítulo analisa as formas e os propósitos das parcerias público-privadas na educação básica e pública no Brasil e a recepção dessas parcerias para o público, especificamente para a rede municipal de ensino do município de Laranjeiras. Sugiro que durante esse trajeto tenhamos algumas perguntas em mente: qual o intuito dos grandes grupos empresarias que, por meio de seus institutos, oferecem projetos e cursos gratuitamente para centenas de município em todo o Brasil? Quem de fato se favorece com esses cursos, o público ou as iniciativas privadas? Como essas pautas ressoam no cotidiano da educação básica? Qual o papel do Estado? 
Capítulo 4. Um Projeto de Nação: perspectivas neocoloniais e as parcerias públicoprivadas na Educação

O objetivo deste capítulo foi apontar as diferentes atualizações e interpretações do colonialismo e como estas perspectivas se intersectam com o projeto de uma "nova" nação preconizada pelos grupos empresariais, por meio de instituições que trabalham com a educação pública e básica brasileira. Veremos, também, como a perspectiva interseccional oferece para esse campo um chão sólido, tensionando esse projeto, provocando desafios para sua implementação e permanência. A voz das gestoras escolares de Laranjeiras, continuará a ecoar nessa trilha.

\section{Ponto de Chegada. Considerações Finais}

Nas últimas páginas da tese, retomo e percorro meus argumentos centrais, finalmente pousando no Ponto de Chegada. Trata-se da última Encruzilhada que encontro na reflexão sobre a pergunta que motivou minha pesquisa: para o público ou para o privado? 


\title{
Prelúdio. Tempos e Temporalidades: um avanço, um recuo
}

\author{
Pode Ligar o Chuveiro? \\ O padrão de poste exigido pela prefeitura agora tem que ter 1 metro e \\ 60. Caixa de frente para rua, com 15 centímetros de teto. Se tiver 10, \\ não lê a sua luz. Multa e corta. \\ Antes era até relógio grudado com fita isolante, chiclete emendando o \\ vidro, palito de fósforo escorando. Tudo de madeira, chumascada tinha \\ uma porção, como as gravuras do curto-circuito esparramadas na \\ taubinha. Mas sem roubalheira. Honestidade e boa vontade pro serviço \\ do rapaz, que, cortando chuva ou comendo sol, todo mês marcava o \\ consumo do quintal. Agora, qualquer frescura, o patrício não confere \\ sua luz. \\ A caixa de energia ali, no banheiro de tomar banho, que o de urinar é \\ na outra banda do quintal. Assim, quando caia a luz, é só esticar bem o \\ braço que dá pra levantar a chave de novo na pontinha do dedo. Mete \\ uma sandália de borracha e volta pra tirar o sabão. É, respinga. Choque? \\ Não, ainda não. Eu não. \\ Aqui, antes de tomar banho, tem que gritar se alguém noutra casa lá \\ embaixo tá no chuveiro. Senão é queda. Sem novela, sem jogo, sem \\ lâmpada. Banho gelado de cano. Penumbra, silêncio e vulto. Comprou \\ vela? \\ - Alan da Rosa, Reza de Mãe
}

As questões que atravessam esse conto/poema/história, apresentam-se como um complexo dilema sobre as realidades sobre as quais tenho me debruçado nos últimos tempos. Aliás, é sobre esses tempos e temporalidades que se assenta esta reflexão.

O conto/poema/história apresenta um passado atravessado por uma reorganização da "contemporaneidade". Um tempo de reformulação das coisas vividas, que segue povoado por coisas que aparentemente não cabem mais na atualidade. Certas experiências continuam sendo vivenciadas por uma parcela da população, que permanece da mesma maneira, vivendo num "passado", contido num presente tecnológico, imperativo e ainda desigual.

$\mathrm{Na}$ antropologia há um extenso estudo sobre as concepções de tempo $e$ temporalidade: no campo nas artes, nos estudos sobre os emaranhados familiares, nos rearranjos políticos, nos estudos regionais. Acrescentei um "s" na concepção de tempo e temporalidade porque acredito que exista mais de um tempo e de temporalidade dentro de um mesmo processo. Minhas ponderações estão firmadas nos contextos e percursos da minha pesquisa.

As concepções de tempos e temporalidades que insistem em me abarcar surgem de várias fontes: das entrevistas com as interlocutoras do meu campo, dos estudos sobre 
as políticas públicas educacionais, dos arranjos das parcerias público-privadas na educação, das relações raciais em contextos específicos, mas não só.

No contexto em que realizei pesquisa, existem muitos tempos distintos e ao mesmo tempo semelhantes em sua forma. Quero dizer com isso que, embora o tempo cronológico linear não pare e variadas temporalidades continuem a atravessá-lo, para um grupo social, a população preta e pobre, os tempos e as temporalidades insistem em mantê-los no tempo das desigualdades.

A atualidade digital, o avanço das tecnologias, as novas formas de produção de vida, a globalização, as conquistas políticas de acesso e identitárias, enfim, todas essas temporalidades que atravessam os tempos, não permitiram o avanço real dessa população, não consentiram que ela alcançasse o mesmo patamar social que a maioria dos outros grupos sociais.

Há, eu sei, muitas explicações para isso: o racismo estrutural, o racismo vivido na prática, o "capitalismo selvagem", por exemplo. O certo é que existe um atraso da população preta e pobre, que, mesmo com tantos avanços ao longo dos tempos, esse anacronismo se mantém, só muda de forma, um anacronismo forjado e destilado pelas concepções imperialistas e que experenciamos até os dias de hoje. Parece-me que temos um Brasil que corre para o futuro, mas não saiu do passado.

Os cenários que vos apresento a partir de agora e que atravessa este trabalho, parte de um eixo fundamental: trata-se de pensar como os tempos e as temporalidades, de maneiras diferentes, contribuem para as reflexões, análises de situações e argumentações sobre contextos atuais que se mostram deslocados no tempo e no espaço, reagindo e contribuindo com os processos de desigualdades em diferentes esferas da vida social. Também, como termos e conceitos vividos por nós, principalmente, no que tange a educação pública e básica do Brasil, se apresentam como "ciladas" colonizadoras e imperialistas.

Para tanto, retomo algumas das elaborações teóricas de Anne McClintock. Vejamos com atenção.

Anne McClintock (2010), em Couro Imperial: Raça, Gênero e Sexualidade no Embate Colonial, analisa as formas de atuação de uma miríade de forças imperiais e antiimperialistas. Seu interesse não é somente por questões teóricas e filosóficas, mas pelo conjunto de desejos e ações das pessoas, que são permeados pelas instituições de poder. Embora os escritos da autora estejam ancorados no cenário sul-africano, há dois pontos 
de sua argumentação teórica que transcende este contexto, e que tomo como uma linha de pensamento para as questões apresentadas ao longo deste trabalho.

As duas linhas teóricas ou pontos que me interessam particularmente são as noções de "tempo panóptico" e "espaço anacrônico" e as críticas sobre os chamados "estudos pós-coloniais". Tempos e temporalidades, juntamente com os argumentos do pós-colonialismo, dão o tom, o eixo, a gradação desta tese.

Meu objetivo não é traçar uma crítica aos estudos pós-coloniais - pelos quais tenho um imenso apreço -, a intenção é olhar para a continuidade do tempo da colonização e trazer para este trabalho uma perspectiva, embora triste, de que a colonização se mantém em diferentes formas ao longo dos tempos; que o passado está tão presente quanto este mesmo presente. A crítica está centrada na ideia de progresso e do tempo linear, visto que, nesta pesquisa, tempos e temporalidades, passado, presente e as ideias de futuro se fundem e a imagens de progresso movimentam diferentes eixos das desigualdades.

McClintock (2010) argumenta que tanto o imperialismo europeu como a invenção da raça não aconteceram em um lugar distante, não são exteriores à identidade moderna. Pelo contrário, para a modernidade industrial ocidental, o imperialismo e a invenção da raça foram aspectos fundamentais. Nas metrópoles, estas foram questões centrais para a definição da classe média e o controle das "classes perigosas": criminosos, militantes, homossexuais, judeus, irlandeses, negros e a classe trabalhadora.

A autora abarca a ideia de raça pensando não somente nos povos colonizados, mas nas prostitutas, judeus e outros grupos. McClintock argumenta que isso não significa cair na indecidibilidade e que interpelar a noção de raça como algo fixo e imutável não denota cessar as discussões sobre raça, também não significa ignorar que a invenção da diferença racial tenha trazido graves implicações. As invenções de hierarquias históricas, assim, são descritas pela autora como ficções que têm efeitos, portanto, é imprescindível que haja atenção a esses tipos de violência e poder.

Anne McClintock faz uma crítica ao conceito de pós-colonialismo trazendo para esta arena uma reflexão sobre o tempo linear e as ideias de desenvolvimento e progresso. O objetivo é repensar os traços de desenvolvimento e progresso na representação de história. A autora questiona que os estudos pós-coloniais vão contra a ideia de tempo linear alçada pelo imperialismo, entretanto, ao usar o termo pós-colonial, esses estudos situam a história em uma série de estágios que vão desde o pré-colonial até o pós-colonial. 
Com isso, mesmo sem intenção, o tempo linear e a ideia de desenvolvimento continuam sendo marcadores da história.

As teorias pós-coloniais, ao utilizarem este termo, novamente reorientam a história global à oposição binária: colonial/pós-colonial. Dessa forma, esses estudos se deslocam do eixo binário do poder entre colonizador e colonizado para o eixo binário do tempo, que é mais nocivo porque não distingue os beneficiários e as vítimas do colonialismo.

A teoria que prometia um descentramento da história, ao lidar com a singularidade do termo faz justamente o contrário, recolocando a história em torno do tempo europeu, do colonialismo. O termo "pós" restringe a cultura dos povos e atribui ao colonialismo o prestígio da história tornando-se o seu marcador definitivo. Este termo, segundo a autora, raramente é usado para denotar pluralidades. Essa categoria tende a ver o globo como abstrações genéricas, correndo o risco de proporcionar uma invisibilidade de questões geopolíticas decisivas.

Outra questão problemática é que o pós-colonialismo, ou o pós-modernismo, tiveram desenvolvimentos desiguais a depender de cada país. Não é possível pensar que diferentes países como a África do Sul, o Zimbábue e o Brasil, por exemplo, compartilham um único passado comum ou uma mesma condição chamada pós-colonial. A autora questiona: "Podem esses países ser entendidos agora como se tivesse sido formado exclusivamente em torno da experiência 'comum' da colonização europeia?" (McCLINTOCK, 2010, p.32).

A celebração que vem com o termo "pós-colonial", portanto, é prematura, ofuscante e instável. Apesar de alguns países serem pós-coloniais, podem hoje não ser em relação aos seus vizinhos. A instabilidade do termo está também em relação às mulheres visto que o Estado pós-colonial não assegurou igualdade de direitos e recursos para homens e mulheres. Quem "calçou os sapatos" do pós-colonialismo e da modernização foram os homens.

A autora apresenta dois tropos fundamentais que sustentaram a ciência imperial, e que também contribuem para o ordenamento teórico e metodológico deste trabalho. São eles: a invenção do tempo panóptico e do espaço anacrônico.

McClintock aponta que, a partir de escritos de cientistas naturais como Darwin e Lineu, os evolucionistas sociais tentaram produzir uma única genealogia do progresso da história do mundo. Com isso, tanto o espaço natural como o tempo histórico passaram a ser captados, reunidos e mapeados numa "ciência global da superfície". A concepção de 
tempo foi secularizada e naturalizada fornecendo ao mundo uma única história e a história passou a ser vista como um espetáculo. O tempo bíblico foi substituído pelo tempo cronológico.

O tempo panóptico, portanto, é aquele que pode ser visto, capturado com um único olhar: "num único espetáculo a partir de um ponto de invisibilidade privilegiada" (McCLINTOCK, 2010, p. 67). Para exibir o progresso era preciso um paradigma visual. Para isso, os evolucionistas sociais criaram a Árvore da Família do Homem.

A árvore traz uma imagem de progresso linear em que as culturas descontínuas são ordenadas dentro da narrativa europeia. As culturas e as descontinuidades históricas são passíveis de serem ordenadas e subjugadas por essa narrativa, além de enunciar o progresso diferencial das raças. Progresso e espetáculo assumem a mesma forma, o desenvolvimento histórico é naturalizado como uma família que evolui.

O conceito de tempo natural foi um tempo secularizado e domesticado. A mescla de família e árvore na Árvore da Família do Homem, que representa a evolução negando a participação de mulheres, deu ao racismo científico a abertura para difundir a imagem de progresso racial. A autora comenta: "Desde o início, a ideia de progresso racial tinha gênero, mas de tal maneira que tornava as mulheres invisíveis enquanto agentes históricos" (idem, p.69).

Uma das marcas do progresso industrial e da classe média vitoriana era a compulsão fetichista de colecionar aquilo que era tido como arcaico, ou seja, tudo que não era da cultura europeia. Neste sentido, o museu "como moderna casa fetiche do arcaico" tornou-se uma das principais instituições que dava corpo para as narrativas vitorianas.

Entretanto no tempo panóptico as imagens aparecem fixas sem mudanças. Contraditoriamente, ao tornar o tempo mercadoria, o trabalho de promover transformação histórica tende a desaparecer. Surge então, no final da era vitoriana, outro tropo com autoridade plena e alta tecnologia administrativa: a invenção do espaço anacrônico.

Nesse tropo, foram colocadas as mulheres, os colonizados e a classe trabalhadora. O espaço anacrônico é o espaço do arcaico, primitivo, atávico, distante da modernidade. Este espaço foi evocado pelos cientistas raciais e eugenistas. A fim de comprovarem o atavismo e retificarem o controle sobre essa população foram inventados estigmas visíveis que representassem o anacronismo histórico das classes concebidas como degeneradas. 
Por exemplo, o corpo da mulher africana tornou-se o arquétipo do atavismo. A mulher negra foi concebida como aquela que condensa um extremado apetite sexual, externado pelos seus órgãos sexuais primitivos. A exibição da africana Sartjie Baartman tornou-se o protótipo da invenção do corpo feminino negro como um espaço anacrônico.

O espaço doméstico vitoriano também foi configurado como espaço anacrônico. "As mulheres que transgrediam as fronteiras do trabalho, do lazer, entre o público e o privado, eram tachadas de 'degeneradas', 'primitivas', 'raças negras', 'escravas'” (McCLINTOCK, 2010, p.75).

Na metade do século XIX, com a concepção de família do homem, a raça foi inventada para configurar a degeneração, a degradação moral e intelectual. As prostitutas, a classe trabalhadora, os pobres, criminosos, alcoólatras eram tidos como desviantes raciais e atávicos, portanto, deveriam ser policiados, pois coletivamente representavam perigo para a metrópole imperial industrial.

A ideia de progresso padecia do medo da degeneração. A relação entre as degenerações de classe, raça e gênero foram instituídas, assim como a sexualidade e o dinheiro desviante eram vistos como interligados pela analogia negativa da raça.

A raça desviante, a sexualidade desviante, o dinheiro desviante, a classe desviante eram tidos como ameaçadoras da economia e do progresso do Estado imperial e deveriam ser vigiados. Entretanto, a autora elucida que:

As classes degeneradas, definidas como desvio do tipo humano normal eram tão necessárias para a autodefinição da classe média quanto a ideia de degeneração era para o progresso, pois a distância percorrida por algumas partes da humanidade ao longo do caminho para o progresso só podia ser medida pela distância em que outras estavam atrasadas. (McCLINTOCK, 2010, p.80).

No final de 1870, as crises sociais aumentavam nas metrópoles e nas colônias. Protestos feministas, o ressurgimento do socialismo, a falta de moradia e emprego, a crescente pobreza, originaram o medo na classe média que, por sua vez, deu origem à "poética da degeneração como via de legitimação".

Isto posto, pretendo seguir essa "linha de raciocínio", ou "inspirações teóricas e metodológicas", no intuito de contribuir e tornar compreensivas as argumentações que compõem esta tese. 


\title{
Capítulo 1. Preta e Cabocla: Laranjeiras, terra de laranjais, quilombos e das complexidades sociais
}

\author{
Cântico/Poesia aos Laranjeirenses \\ Minha terra Laranjeiras. Terra de lindas palmeiras \\ Adoro tudo que é teu. Admiro os belos prados \\ $\mathrm{E}$ adoro os lindos trinados. Das aves que Deus te deu \\ Admiro o candomblé. E o Zabumba do José \\ Torrentes de poesia! Amo a face angustiada \\ Da imagem cobiçada. Do Senhor da Pedra Fria \\ Admiro os Caboclinhos. E os Negros do Rei Raminho \\ Lamentando o cativeiro! E a cantoria bonita \\ Da turma do João de Pita. No dia seis de janeiro \\ - João Sapateiro, Poeta Laranjeirense
}

Este poema João Sapateiro fez em homenagem aos moradores de Laranjeiras. O poeta, que passou a vida neste município, é reconhecido como um dos maiores artistas nascidos em Sergipe. João Silva Franco, homem negro sergipano, torna-se João Sapateiro por conta do seu ofício e até hoje é lido e venerado no município. Suas poesias contam histórias da sua vida como um homem negro trabalhador e relatam a paisagem, as belezas, a cultura e a população de Laranjeiras.

O objetivo deste capítulo, como enunciado na Introdução é apresentar para a leitora e para o leitor o município de Laranjeiras. As paisagens, o modo de vida, as sociabilidades dos citadinos, as vivências culturais e as peculiaridades que movimentam os munícipes. Adianto que esses tópicos não se encerram por aqui, eles estarão presentes nos demais capítulos. Esta apresentação, que também é histórica, tem uma intencionalidade, qual seja: dirigir a leitura dando luz, foco e tinta para os assuntos que tratamos nesta tese.

Laranjeiras faz parte dos 75 municípios que compõem o estado de Sergipe, e com nove deles, faz parte do chamado Vale do Contiguiba. O Vale é entrecortado por rios. A produção do sal, da pesca, do coco e do feijão, além da produção açucareira estavam espalhados em toda a região e eram cultivadas por mão de obra escrava. Laranjeiras também se localiza na região metropolitana estendida de Aracaju.

Sergipe no século XIX foi um grande produtor de açúcar da região nordeste. Detinha parte da economia açucareira, implicando em um número grande de mão de obra escrava na região. Aracaju, serviu como porta de entrada de escravizados para a região e consequentemente para Laranjeiras. 
Wellington de Jesus Bonfim (2006) discorre sobre uma bibliografia que indica a chegada na região de escravizados de dois diferentes grupos étnicos no final do século XVIII e início do XIX: os Nebaia e os Samba. Quem abastecia a região com mão de obra escrava era a Costa dos Escravos e Daomé, por meio de acordos com Francisco Felix de Souza. Ele foi um dos maiores comerciantes de escravizados da região, brasileiro mestiço que passou a usar o codinome de Mongo Chacha, e estreitou relações com comerciantes importantes do reino de Daomé (BONFIM, apud BARRETO, 2005, p.24).

No entanto, o autor assinala uma inconsistência na literatura que trata do comécio de escravizados em Sergipe. Maria Tetis Nunes (1999) aponta que a chegada dos escravos em Sergipe se iniciou em 1590, quando a economia açucareira ainda não era intensa em Laranjeiras. Já Felte Bezerra (1984) indica uma variante e situa a chegada de africanas e africanos em 1575 e que esses - ao contrário da hipótese de Barreto (2005), que dizia que eram Nebais e Samba - eram sudanezes e bantos. Inclusive, esta é a tese defendida por uma das maiores estudiosas da região, Beatriz Goes Dantas (1988).

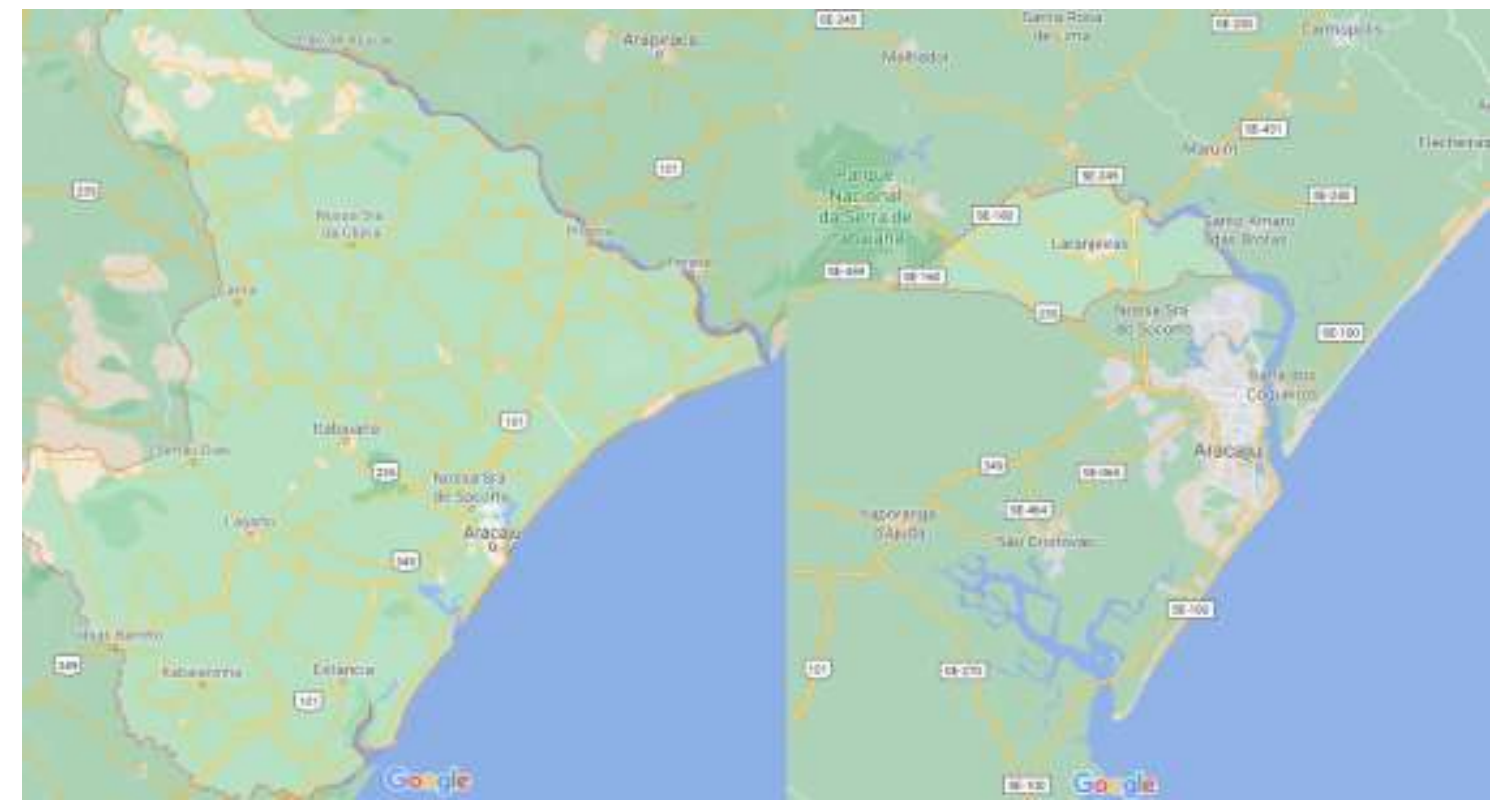

Mapas do estado de Sergipe (esquerda) e da localização do município de Laranjeiras (direita). Fonte: Google Maps

Os estudos sobre Laranjeiras e a região do Vale do Contiguiba têm um viés no processo escravista. Esses estudos buscam acompanhar a trajetória deste processo, a fim de traçar um perfil racial, antropológico, histórico e cultural dessa populção. Dentre os estudiosos dessa abordagem, destacam-se José Modesto Subrinho (2000); José Maurício 
Arruti (2006) e Luis Mott (1986). A formação de quilombos, os processos de produção dos engenhos, as expressões culturais negras, o processo escravista, são alguns destaques dessa bibliografia, que reporta a existência de uma quantidade grande de quilombos na região do Contiguiba e especialmente na chamada Vila de Laranjeiras

Bonfim (2006) aponta que existe alguns desencontros na literatura sobre o processo escravista em Sergipe. Sabe-se, por exemplo, que em Laranjeiras, durante o período escravocrata, por volta de 1854 a população livre era maior que a cativa. Segundo algumas bibliografias que analisam dados estatísticos oficiais da época, isso aconteceu pela existência da prática de alforrias na região, mesmo antes da abolição da escravatura, e que parte da populção livre era composta por ex-escravizados trabalhando nas lavouras como empregados dos engenhos.

Os dados estatísticos e as contradições núméricas foram pontos pesquisados por estes autores. Incoerências nos dados históricos dificultam traçar exatamente o perfil racial da região no período escravocrata, mas abrem a possibilidade de analisar como os proprietários das fazendas agiam para bular as leis, inclusive sonegando informações que poderiam atrapalhar o seu comércio. Há um descompasso percentual nos dados oficiais instigados pelos proprietários.

Bonfim (2006) aponta que, na contemporaneidade, Laranjeiras foi alçada a um lugar de efervescência cultural negra de Sergipe. Alerta que há uma invisibilidade, ou não reconhecimento da população indígena nos processos sociais, históricos, culturais e pouca representação sobre essa população nos estudos da região. $\mathrm{O}$ autor sugere que há um domínio da história laranjeirense por parte de alguns setores públicos e privados do município interessados apenas em atender interesses específicos:

Algumas chamadas publicitárias que procuram demarcar a cidade de Laranjeiras pelos órgãos públicos locais demonstram a ênfase no discurso sobre a importância de sua cultura na caracterização de suas potencialidades: "museu a céu aberto", "berço da cultura negra em Sergipe", ou ainda, "capital da cultura sergipana". Cognomes justificados pela importância cultural e econômica obtida no século anterior (Bonfim, 2006, p.44).

Laranjeira teve alguns dos seus patrimônios históricos recuperados, na tentativa de transformar o município em um polo turístico da região. Certos prédios, ruas e praças foram selecionadas por grupos de interesse dos setores públicos e privados para o restauro e conservação. $\mathrm{O}$ foco dessas ações voltou-se para as pretensões turísticas, destacando a 
presença histórica de africanos e portugueses como parte desse cenário, sem nenhuma relação com a população local atual.

Na década de 1970, Laranjeiras passa por uma decadência política e econômica. Esses grupos de interesse, prevendo verbas públicas para o turismo, promovem o município como "Patrimônio Arquitetônico Barroco do Nordeste". Bonfim (2006) relata que o processo de alçar Laranjeiras a maior centro histórico e cultural de Sergipe foi marcado por intercorrências e suspeitas: "porém, algumas conquistas podem ser evidenciadas, ainda nesta perspectiva do turismo cultural. Trata-se da formação do Museu de Arte Sacra (1973), a Casa João Ribeiro (1973) e o Museu Afro Brasileiro de Sergipe (1976)" (BONFIM, 2006, p.48). Neste meandro cultural, a presença histórica acentuada do contingente de escravizados na região foi decisiva para pensar em uma elaboração de uma representação local de identidade e cultura negra.

A dança de São Gonçalo do Amarante, festejada no povoado de Mussuca, e a festa do Lambe Sujo versus Caboclinhos são os principais objetos de estudos contemporâneos sobre manifestações culturais negras em Laranjeiras. Os festejos focalizam o período escravocrata como seu ponto de partida. Os autores que se dedicam a esses temas apontam para um processo social de afirmação étnica por meio das manifestações culturais negras e reconhecimento da identidade negra e laranjeirense por meio da ligação histórica com os negros africanos escravizados no Brasil.

Munanga (2009) assinala que a cultura não passa pela cor da pele, mas, quando uma determinada cultura é entendida no seu processo histórico e social, ela ganha aderência aos grupos que a reivindicam comportando ideias de resistência cultural. Já a identidade negra passa pela cor da pele, passa pela raça, em assumir o seu corpo, em aceitar a sua história e a sua cultura. A história da população negra foi negada e renegada, então, as manifestações culturais são uma forma de constantemente reconstruí-la. A constituição dessa identidade negra não é fixa, está em constante construção a depender dos contextos políticos, de gênero, de classe e, principalmente, de geração.

Veremos agora um pouco do olhar etnográfico desta pesquisadora, as vivências e sociabilidades estabelecidas no encontro com Laranjeiras, que se tornou, mais adiante, seu campo de pesquisa. 


\subsection{Daqui Pra Lá, De Lá Praqui: olhares etnográficos, histórias consideráveis}

Como já indiquei, minha inserção em Laranjeiras se deu por meio de um convite para acompanhar o trabalho das escolas e da Secretaria de Educação que, naquele momento, estavam colocando em prática um projeto advindo de uma parceria públicoprivada de uma instituição ligada a um grande grupo empresarial. Com essa atividade, visitei Laranjeiras durante um ano, entre idas e vindas em 2017 e passei a frequentar o município formalmente como antropóloga pesquisadora no ano 2018. Aqui, registro algumas experiências cruzadas entre Aracaju, Laranjeiras e mesmo minhas experiências pregressas desde São Paulo, de modo a situar o olhar etnográfico que fui compondo conforme passei a me deslocar entre esses espaços variados.

Foi de Coroa do Meio que saí para conhecer pessoalmente Laranjeiras pela primeira vez. Este é um bairro que fica numa região considerada nobre de Aracaju, capital do Sergipe. Coroa do Meio é banhado, de um lado, pelo Rio Sergipe e, de outro, pelo oceano Atlântico. O bairro é dotado de uma paisagem linda, com um manguezal incrível e uma pista de passeio para caminhada e corrida recortando toda essa paisagem. Do quarto do hotel, onde eu me hospedei durante um ano em todas as vezes que ia para Laranjeiras, era possível não só ver o nascer e o pôr do sol, mas também sentir o calor dos raios alaranjados.

Durante esse tempo, eu tive uma companhia gentil e apaixonada pelo Sergipe, principalmente por aquelas regiões por onde passávamos até chegar ao nosso destino. Nininho, um taxista de 55 anos, era um verdadeiro historiador da região, simpático e conservador. Todas as vezes que ele me pegava no hotel, repetia: "dona Valéria, a senhora está bem hospedada, os artistas que vêm fazer show em Aracaju só ficam neste hotel. A senhora já viu algum?”. No início, minha resposta era sempre negativa e ele ficava me olhando desconfiado. Depois, comecei a perceber que os artistas, em sua maioria músicos com suas bandas, de fato, ficavam hospedados lá. Acontece que eu não os conhecia, não faziam parte do meu repertório, porém, no decorrer do tempo, comecei a reconhecê-los, principalmente por conta da quantidade de fãs que se alvoravam na portaria do hotel, enquanto os seguranças tentavam mandá-las embora.

Os shows geralmente aconteciam às margens do Rio Sergipe, ao lado do manguezal. Da janela do meu quarto, eu via todo o movimento, as milhares de luzes de led coloridas dos palcos, a circulação de pessoas dentro e fora do hotel. Nininho me disse 
que nunca tinha ido num show naquele espaço, pois era muito caro, "só pros ricos", dizia ele. Eu, para me distrair, ficava na área de lazer do hotel, que funcionava como um mirante, sendo possível ver toda movimentação. Ficava contando quantas pessoas negras entrariam para ver - essa é uma mania que tenho, olhar quantas pessoas negras frequentam determinados espaços. Em geral, eram bem poucas, grande parte do público eram mulheres brancas, com os cabelos alisados, bem maquiadas e com cílios postiços. Muitas usavam cílios, acho que estava na moda. Presenciei alguns grupos de amigas jantando no restaurante do hotel antes dos shows, todas com "cara de ricas", conversavam parte das vezes sobre relacionamentos afetivos que não deram certo e de como elas eram lindas e estavam ali para se divertirem com as "migas" e que, com sorte, encontrariam um "boy magia" para beijar a noite toda.

Esse é um dos cenários que vivenciei em quatro das seis vezes que me hospedei neste hotel. Uma realidade muito diferente daquela que presenciaria em Laranjeiras. $\mathrm{O}$ que, para as "migas" era uma realidade comum, talvez habitual, para as mulheres de Laranjeiras que conheci isso era, por vezes, um sonho talvez não realizável, só um sonho. Descobri isso bem depois, em conversa com algumas delas.

Certa vez, durante um café da tarde na Secretaria de Educação após uma reunião, começamos a conversar sobre os lugares interessantes para se divertir em Aracaju. O Museu da Gente Sergipana começou a ser citado por algumas gestoras. Foi aí que uma delas exclamou: “Gente! O museu é lindo, mas não é divertido, vamos falar sério...” foi numa gargalhada só e todas concordaram. Uma funcionária da Secretaria de Educação, do administrativo, começou a falar sobre lugares para dançar, casa de show etc. Todas foram complementando. Certa hora, eu comentei sobre o espaço de Shows em Coroa do Meio, aí, o assunto rendeu.

Não consegui reproduzir as falas na íntegra, pois, naquele momento de descontração, eu não estava gravando ou tomando notar. A conversa surgiu e, logo depois, fiz anotações em meu caderno de campo. Pensei que, em algum momento, eu poderia utilizá-las em minhas elucubrações.

Parte das mulheres que estavam ali, heteroclassificadas por mim como mulheres negras e afro-indígenas, queixavam-se de não poderem ir aos shows em Coroa do Meio por conta do valor dos ingressos e de toda tecnologia de estética, transporte, hospedagem que compunham a cena dos shows naquele espaço. Além dos ingressos, que custam cerca de 150 reais, era preciso uma boa produção estética que incluía manicure, cabelereira, roupa nova, além do taxi e de uma possível hospedagem, a depender do horário de término 
do evento. Um custo, que segundo elas, era quase de 300 reais. Relataram-me que já tinham ido uma, algumas delas duas vezes neste espaço por diferentes motivos: uma era muito fã do artista, outra ganhara um ingresso de presente de aniversário, ainda outra havia acompanhado a filha em um show de uma artista que gostava muito. Disseram que as moças de Laranjeiras nutriam esse sonho de ir a um show lá em Coroa do Meio, que algumas até faziam loucuras, como gastar todo o dinheiro do estágio para ir. Contudo, muitas delas nem isso tinham, e também diziam que não era possível ir a este lugar sem uma "super produção", enfim, era um sonho, eventualmente possível de ser realizado.

Enquanto a conversa rolava, eu me lembrava das mulheres que eu via lá no hotel, das conversas e do perfil delas. Gênero, raça e classe, essa tríade, que alguns a chamam de maldita, apresentavam-se de forma explícita aos meus olhos. Lembrei-me das escritas da Anne McClintock, ao dizer que, no embate colonial, as mulheres colonizadas enfrentavam duas estruturas de desigualdade diferentes: na relação com os homens colonizados e com os homens e mulheres brancas do império.

As mulheres brancas (coloniais) do império habitariam uma situação ambígua e também experimentavam as vantagens e as contradições sociais de maneiras diferentes da dos homens brancos (coloniais). Embora estando longe das arenas políticas e do poder formal, exerciam grande poder sobre as mulheres e homens colonizados. Fossem essas mulheres locadas para a servidão doméstica, sexual ou primorosas esposas de oficiais, aqui é o privilégio da raça e não do gênero que sustenta a situação de poder.

A autora observa que "as mulheres brancas não eram as infelizes passantes do império, mas cúmplices ambíguas, tanto como colonizadoras quanto como colonizadas, privilegiadas e restringidas, fossem passivas ou ativas" (McCLINTOCK, 2010, p.22). Expandindo esse argumento da autora, é possível apontar que raça e gênero são articuladores, tanto de um lado como de outro. E no caso em questão, promovem um notável desequilíbrio de poder.

Se essas foram algumas das experiências que marcaram meu olhar para Laranjeiras, elas não foram as primeiras aproximações que tive com a cidade e suas histórias. Ainda na graduação, em São Paulo, eu fiz uma disciplina sobre antropologia e arte. Era a história do Brasil contada através dos artistas e de suas obras. A disciplina tinha um recorte de época, o século XIX, período de grande efervescência das artes e academias de Belas Artes no Brasil. Para minha surpresa, nesta disciplina, não estudamos nenhum artista negro. A avaliação da disciplina contava com uma prova e um trabalho final. A recomendação foi que escolhêssemos um artista e uma obra para analisarmos de 
acordo com a bibliografia da disciplina. Escolhi, então, escrever sobre Horácio Hora, pintor negro dos 1800 nascido em Laranjeira. Foi aí, através dos livros e da pesquisa que conheci o município. Não fui muito feliz nesse trabalho, mas naquele momento de descoberta, desejei um dia ir a Laranjeiras, e fui, anos depois. Aproveito o ensejo para apresentar este pintor, que faz parte do cenário histórico de Laranjeiras com o intuito de levá-los a conhecer um pouco mais das cenas do município.

Horácio Hora (1853-1890) foi um pintor e escultor autodidata reconhecido e estimado no meio artístico brasileiro principalmente pela elite política sergipana ${ }^{2}$. Sem instrução formal, e vindo de uma família de baixa renda, começou, ainda em Laranjeiras, durante a sua juventude, a esculpir imagens de santo no seguimento barroco popular. Sua arte, considerada excepcional, rendeu-lhe uma bolsa de estudos na Escola Municipal de Desenho e Escultura em Paris no ano de 1875. Foi tutoreado pelo pintor francês Alexandre Cabanel (1823-1889)

A historiadora e escritora Maria Thetis Nunes (1925-2009) ocupava a cadeira 39 da Academia Sergipana de Letras. Considerada uma das principais intelectuais sergipanas (Oliveira, 2017), historiógrafa, produziu a síntese da História da Educação Sergipana: da colônia à república. Em seu artigo "Horácio Hora, o esquecido pintor romântico", fez a seguinte consideração:

\begin{abstract}
Sua tendência artística se formou espontaneamente, em contato com a vestuda cidade onde nasceu e passou infância e juventude, Laranjeiras hoje enquadrada entre as cidades históricas. Foram os velhos sobrados patriarcais, as antigas igrejas onde artistas rústicos haviam deixado a exteriorização do sentimento e da fé, os imensos canaviais, os engenhos fumegantes e os saveiros carregados de açúcar cortando o rio Cotinguiba, que marcam a sensibilidade da criança pobre que ele foi. Vagando por essas paragens, ia rabiscando os primeiros desenhos que substituíram o pouco interesse pelos deveres escolares. Ali, em tenra idade já pintava com maestria expressivas figuras, na cal das paredes da cidade, zombando dos burgueses apatacados. Mais tarde, quando retornou à Paris com conhecimentos técnicos aprimorados em estudos com mestres renomados, fixou as impressões da terra natal em diversos quadros como Vista Geral de Laranjeiras, Praça da Matriz, Ponte Nova, Gruta da Matriana e Cascata D'Ouro (NUNES, 1999, p.223).
\end{abstract}

A autora aponta que Horácio Hora pouco circulava pelos centros de efervescência artística do momento no Brasil, que se concentravam na capital, Rio de Janeiro. Sua

\footnotetext{
2 NEGROS Pintores (2008: São Paulo, SP). In: ENCICLOPÉDIA Itaú Cultural de Arte e Cultura Brasileiras. São Paulo: Itaú Cultural, 2019. Disponível em: <http://enciclopedia.itaucultural.org.br/evento558273/negros-pintores-2008-sao-paulo-sp>. Acesso em 19 de agosto de 2019.
} 
vivência e exposições ficaram circunscritas a Paris, Sergipe e Salvador, onde lhe foi concedido, pela Escola de Belas Artes da Bahia, o título de Acadêmico de Mérito e Membro Correspondente, após a exposição de uma das suas maiores obras: Pery e Cecy. Sem ter conseguido grandes êxitos no Brasil, por conta da sua descendência racial, pois era considerado um "mulato", Hora voltou à Paris e lá, "vítima" de um amor não correspondido, e na tentativa de sê-lo, vendeu todas as suas coisas e, por último, seu cavalete: 'Romanticamente, morreu em 'esmagadora miséria', em Paris, ao escravizar-se a uma paixão que o levou até às últimas consequências fazendo-o abandonar compromissos artísticos e desprezar oportunidades promissoras" (NUNES, 1999, p.225). Após ter produzido 200 obras em toda sua vida, o pintor perdeu-se a vagar pelas ruas parisienses e morreu aos 37 anos de idade, vítima de pneumonia. Algumas de suas obras estão no Museu Histórico de Sergipe, no município de São Cristóvão.

Estes apontamentos iniciais dão um pouco de tons e cores ao cenário de Laranjeiras, suas histórias oficiais e cotidianas, a partir das aproximações que fui estabelecendo com o local. Seguimos a partir daqui com percursos pela cidade, seus patrimônios e os eventos que a animam, a partir de documentos oficiais e de minha vivência e análises.

Os documentos oficiais que citaremos ao longo desse percurso tratam-se de poucos materiais disponibilizados pela biblioteca municipal de Laranjeiras. Quase todos dedicam-se a mostrar as rotas turísticas da região e dos Encontros Culturais de Laranjeiras que acontecem há dezoito anos. 


\subsection{Os Caminhos: culturas da fé}

Ao entrar em Laranjeiras, avistei do alto de uma colina uma igreja centenária. Nininho logo me deixou a par que o município era cercado e cortado por muitas igrejas históricas. Aquela imponente, no alto do morro, era a Igreja do Bom Jesus dos Navegantes, com uma arquitetura de estilo colonial. Como ela, existem mais nove espalhadas por todo o território. Um dos slogans do município é "Laranjeiras: terra da cultura e da fé". Realmente, penso, fé é cultura e cultura é fé. Os muitos movimentos culturais da cidade têm ligações ou tons religiosos e foram quase todos nascidos no período escravocrata. Percorro aqui alguns caminhos por esses espaços de fé da cidade de Laranjeiras.

Dentre as igrejas de ordenação católica destaco a Igreja Nossa Senhora da Conceição dos Pardos, erguida por volta de 1843. Conta a história local falada e impressa em documentos que a iniciativa de construir essa igreja veio da necessidade dos habitantes "pardos" à época não se sentirem à vontade professando sua fé nem nas igrejas dos brancos, que eram e ainda são a maioria, e nem na igreja dos pretos - Igreja de São Benedito e Nossa Senhora do Rosário, construída no século XIX pela população preta local e frequentada por ex-escravizados que, por conta da segregação racial, eram proibidos de entrar nas igrejas dos brancos.

Diferente dos negros, que eram proibidos de participar dessas celebrações, esses homens tinham a permissão de frequentar os templos católicos. No entanto, eram extremamente discriminados - por isso, ergueram um templo em honra à Nossa Senhora da Conceição (...). Possuindo uma arquitetura muito peculiar na região, apresentando, por exemplo, um frontão decorado por azulejos portugueses, a Igreja Nossa Senhora da Conceição dos Pardos representa muito mais do que a fé de um grupo de pessoas que lutava por sua liberdade sociorreligiosa e cultural (Projeto Identidades Laranjeiras, 2003, p. 9-17).

Além dessas igrejas históricas de ordenação católica, entre os espaços da fé há também a primeira igreja presbiteriana do município e casas de religiões de matriz africana, como o Terreiro de Candomblé Filhos de Obá. Documentos oficiais datam a fundação desse terreiro ainda no período escravocrata, construído por africanas e africanos descendentes do antigo culto nagô. Esse terreiro, assim como as igrejas, é tombado pelo Patrimônio Histórico e Cultural do Estado de Sergipe. Sigo um percurso por esses espaços tombados, a partir dos documentos Projeto Identidade Laranjeiras (2005) e Mapa Turístico de Laranjeiras (2018). 


\section{Igreja Matriz do Sagrado Coração de Jesus}

Construída em 1869 em estilo barroco, foi erguida com o auxílio financeiro do Coronel Felisberto de Oliveira Freire, que se tornou o Barão de Laranjeiras.

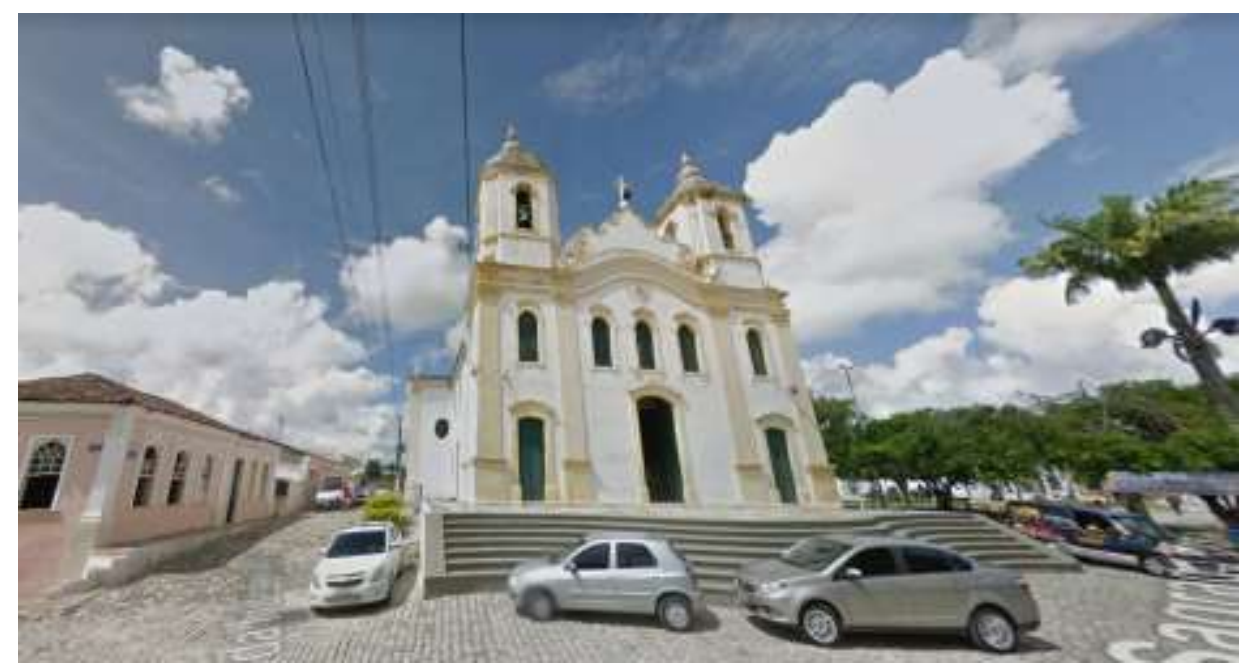

Igreja Matriz do Sagrado Coração de Jesus. Fonte: infonet.com.

No mesmo ano em que a igreja começou a ser erguida, 1860, o então imperador D. Pedro II, ao visitar Laranjeiras, foi conhecer a obra levado pelos integrantes da Irmandade dos Homens Pardos. Ele ajudou a finalizar a obra com uma doação em dinheiro.

\section{Igreja de Santo Antônio}

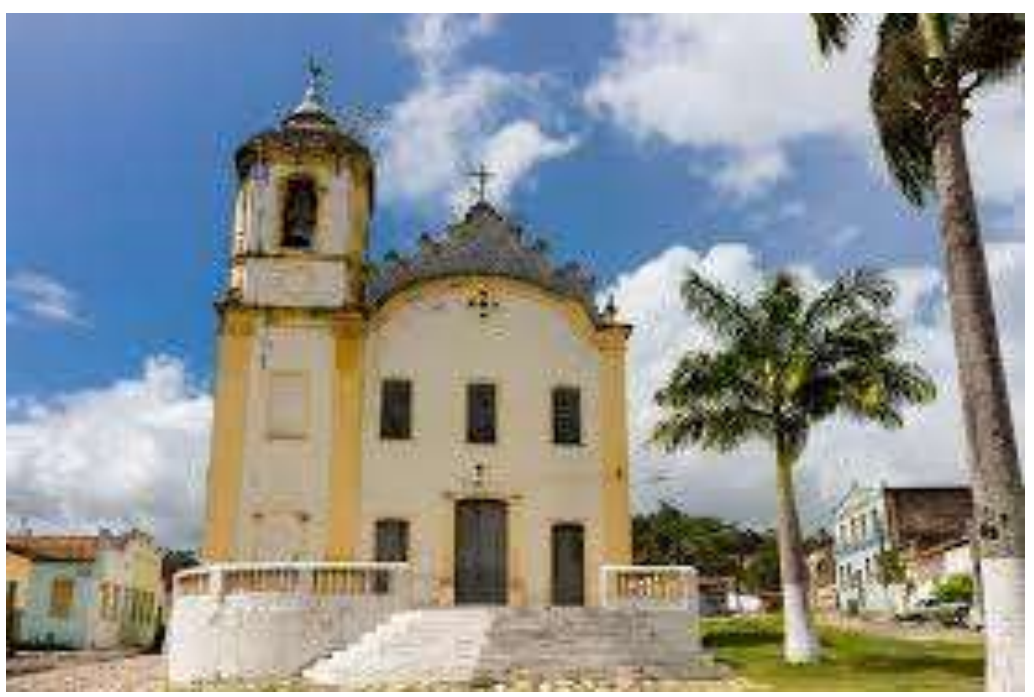

Igreja de Santo Antônio. Fonte: infonet.com. 
A chegada dos jesuítas no Vale do Contiguiba aconteceu já no século XVII. Eles fundaram em Laranjeiras sua primeira residência, em um local que denominaram "Retiro". Além da casa, construíram uma capela e uma senzala para os negros, não existindo desta nenhuma evidência arquitetônica atualmente. Foi a partir dessa localidade que os padres iniciaram o processo de evangelização por toda a região, interrompido apenas em meados do século XVIII, por conta da expulsão da Companhia de Jesus de todas as colônias portuguesas.

\section{Igreja de São Benedito e Nossa Senhora do Rosário}

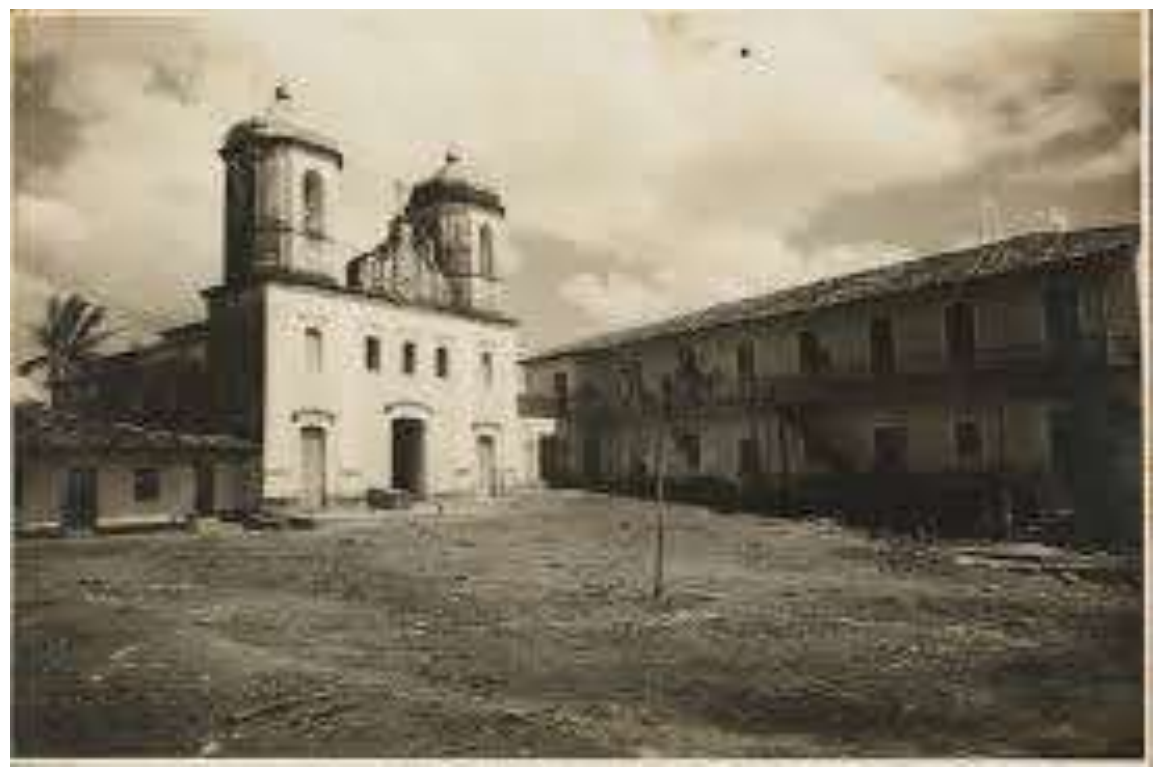

Igreja de São Benedito e Nossa Senhora do Rosário. Fonte: infopratrimonio.org.

São Benedito e Nossa Senhora do Rosário eram os santos dos devotos negros à época. Além das missas tradicionais, outros rituais e manifestações de origem africana eram celebradas nesse local diferenciando-se das práticas da elite branca católica laranjeirense. 


\section{Igreja Senhor do Bonfim}

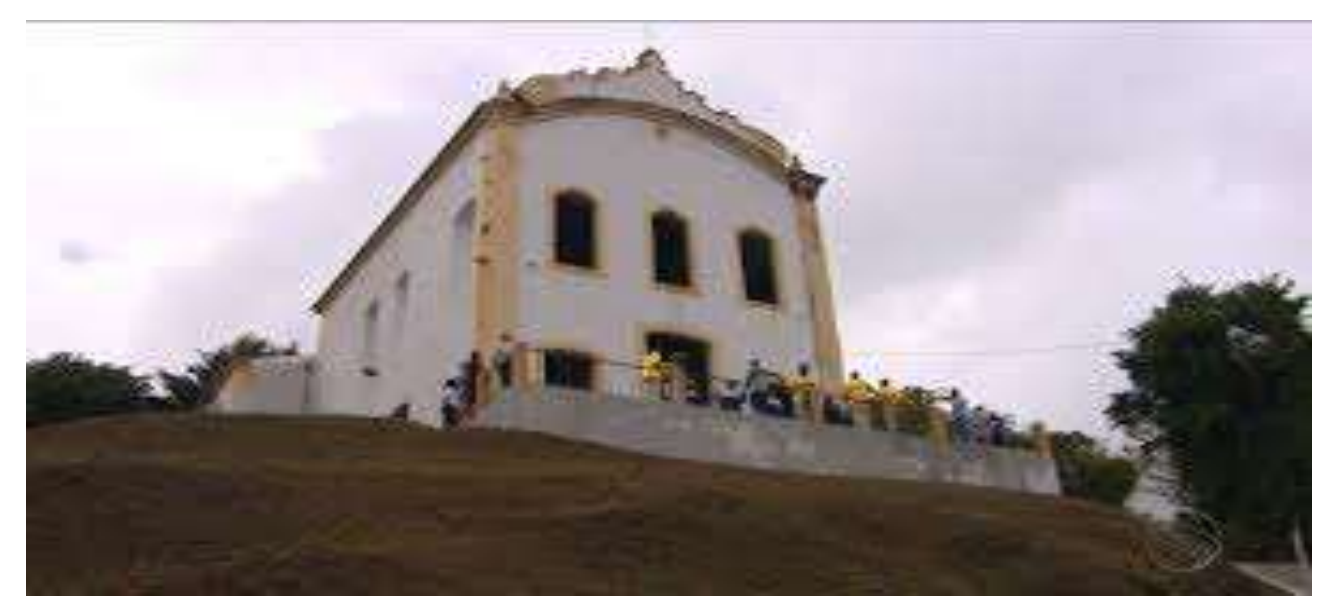

Igreja Senhor do Bonfim. Fonte: infopratrimonio.org.

Essa igreja foi construída, em 1835, em um dos pontos mais altos do município chamado Colina Azulada ou Morro do Bonfim. Dela, vê-se uma vista panorâmica de Laranjeiras e de todo o Vale do Continguiba.

\section{Igreja do Bom Jesus dos Navegantes}

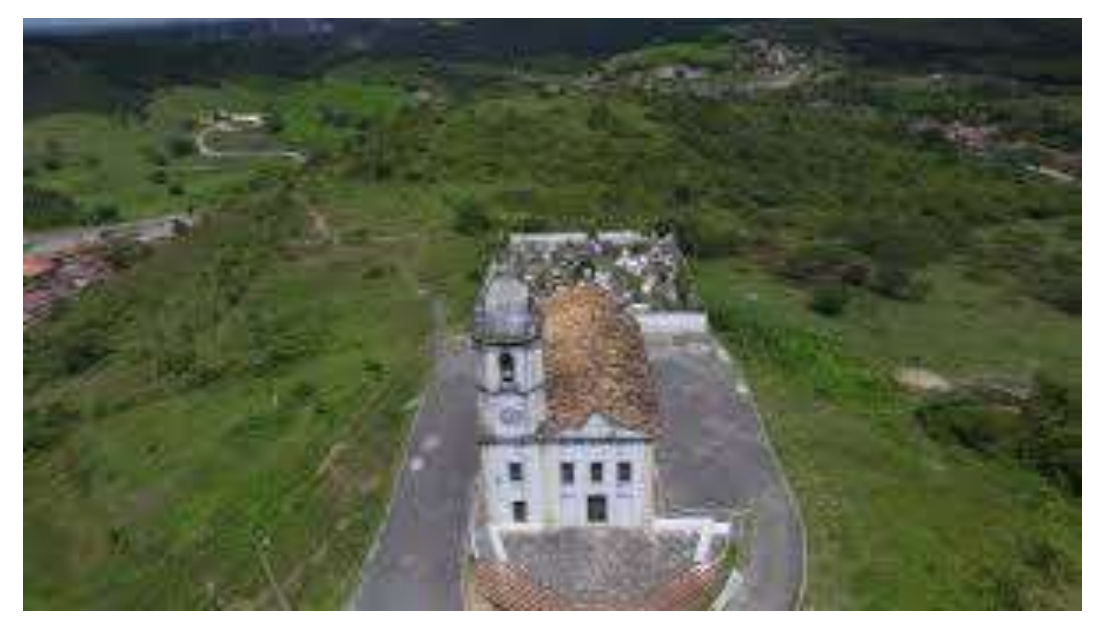

Igreja do Bom Jesus dos Navegantes. Fonte: infopratrimonio.org.

Com arquitetura no estilo colonial, a Igreja Bom Jesus dos Navegantes foi construída em 1905, também em uma parte elevada donde se avista toda cidade. A festa de Bom Jesus é uma das mais frequentadas pelos munícipes e turistas que acompanham a procissão fluvial por todo Rio Continguiba. 


\section{Igreja Presbiteriana}

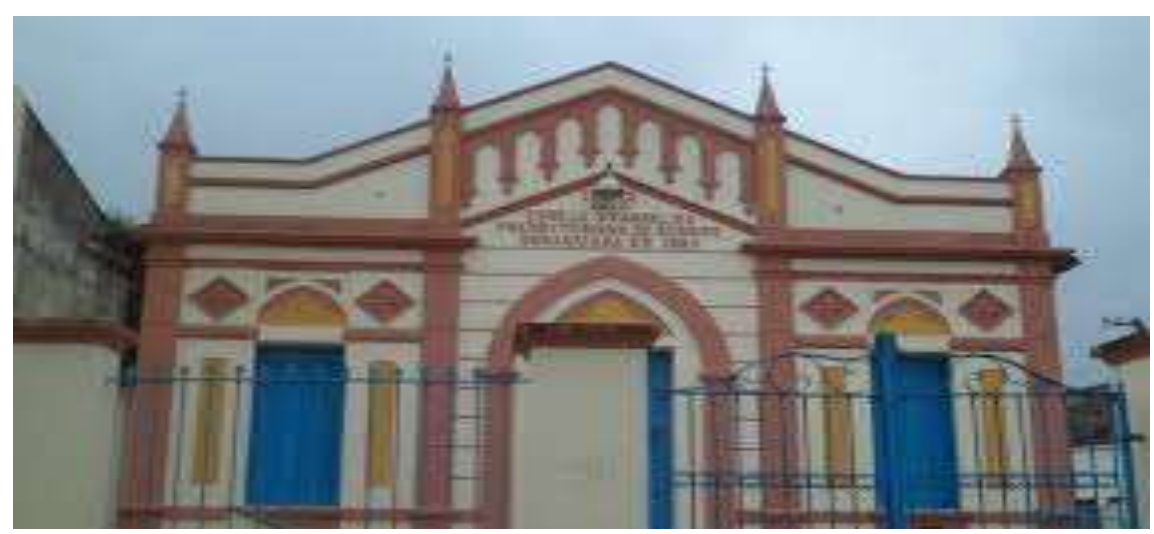

Igreja Presbiteriana. Fonte: infopratrimonio.org.

Fundada em 28 de dezembro de 1884, foi o primeiro templo protestante de Sergipe. Erguida em meio aos conflitos políticos e ideológicos com os católicos conservadores locais, o reverendo Kolb, com seus ideais liberais, conseguiu o apoio da elite, expandindo suas ideias religiosas por todo o estado de Sergipe.

\section{Terreiro Filhos de Obá}

Regido pelo Orixá Obaluayê, além do barracão, o terreiro possui quartos para os orixás, chamados também de assentamentos, e a roça, que é um espaço amplo externo dedicado aos rituais e oferendas.

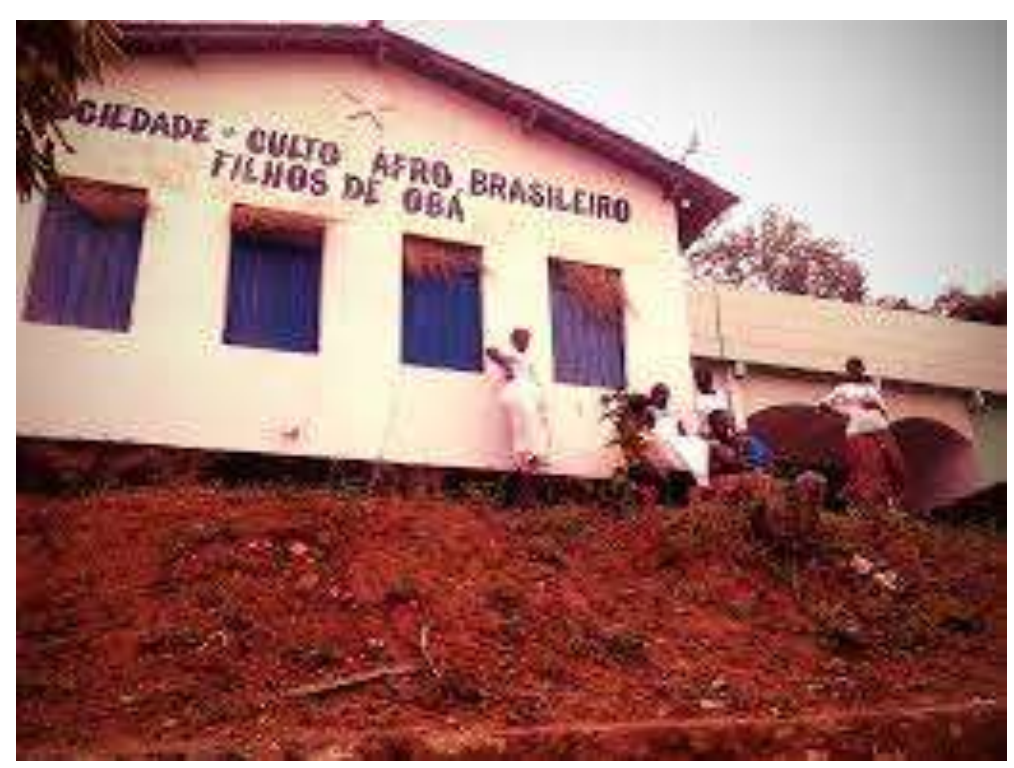

Terreiro Filhos de Obá. Fonte: flickr.com. 


\subsection{As Trilhas: fé nas culturas}

No mês de janeiro 2018, realizei minha primeira imersão no meu campo etnográfico. Embora eu tenha convivido com as interlocutoras durante o ano de 2017 e colhido muitas informações necessárias a esta pesquisa, foi a primeira vez que fui a Laranjeiras somente com o objetivo de participar de algumas manifestações culturais.

Cheguei ao município no dia 04 de janeiro. A cidade estava em festa por conta do Encontro Cultural de Laranjeiras, que acontece há dezoito anos. O tema daquele ano foi: "Nosso Palco é a Rua", e aconteceu entre 03 e 07 de janeiro. Com uma programação cultural extensa, a população nativa e turistas puderam participar de seminários sobre arte e cultura, exposições, oficinas de dança e música e muitos shows divididos em seis palcos, além das atividades que aconteceram nas ruas, como os cortejos dos grupos de cultura popular tradicional e as peças teatrais de rua.

A cidade estava repleta de turistas e quase todos os prédios tombados pelo patrimônio estavam abertos e receptivos: igrejas, museus, casas de cultura, centro de tradição. Uma equipe organizada formada por muitos jovens acompanhava os turistas na visitação destes lugares.

Participar deste momento foi uma experiência muito interessante para esta pesquisa, pois apreciei uma Laranjeiras que, embora eu já tivesse ouvido falar sobre a agitada produção cultural, ainda não havia conhecido. Em conversas anteriores com jovens estudantes, o que eu mais ouvira fora um desgosto e uma chateação em viver em Laranjeiras. A falta de oportunidades de trabalho e estudo, a escassez de lazer, a situação precária dos edifícios da cidade tombada pelo patrimônio e sem conservação faziam de Laranjeiras um lugar inóspito para viver, segundo eles.

O Encontro Cultural contou com apresentações de grupos de cultura tradicional do município e, também, com shows de bandas e cantores de diferentes seguimentos: forró, brega, samba, pop-rock, sertanejo. Apresento aqui, algumas imagens que registrei durante esse percurso, costuradas à descrição de algumas das manifestações da cultura popular religiosa tradicional que compõem a agenda de festividades local. 


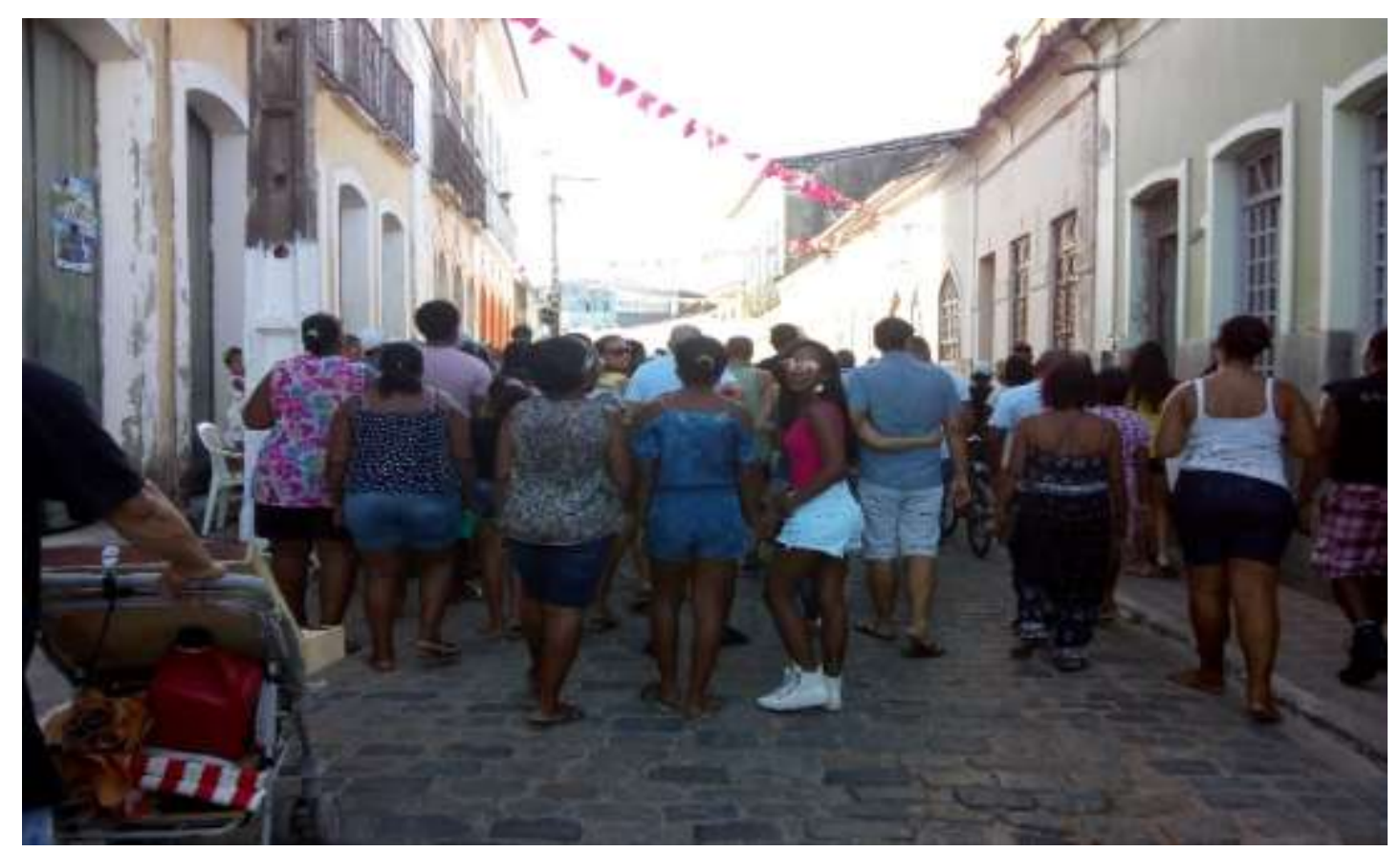

Procissão de Nossa Senhora da Conceição dos Pardos. Fonte: Valéria Alves, 2018.

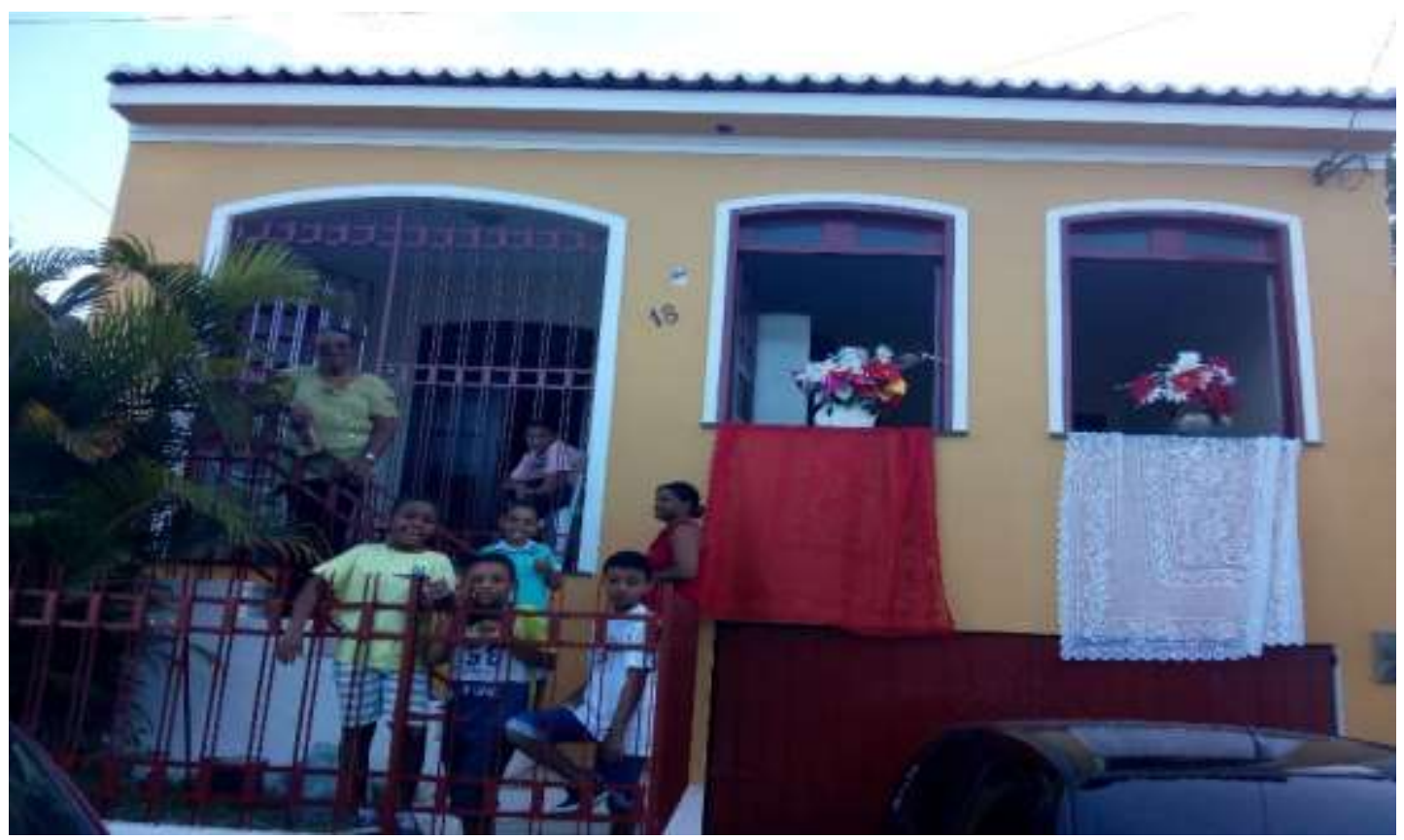

Procissão de Nossa Senhora da Conceição dos Pardos. Fonte: Valéria Alves, 2018. 


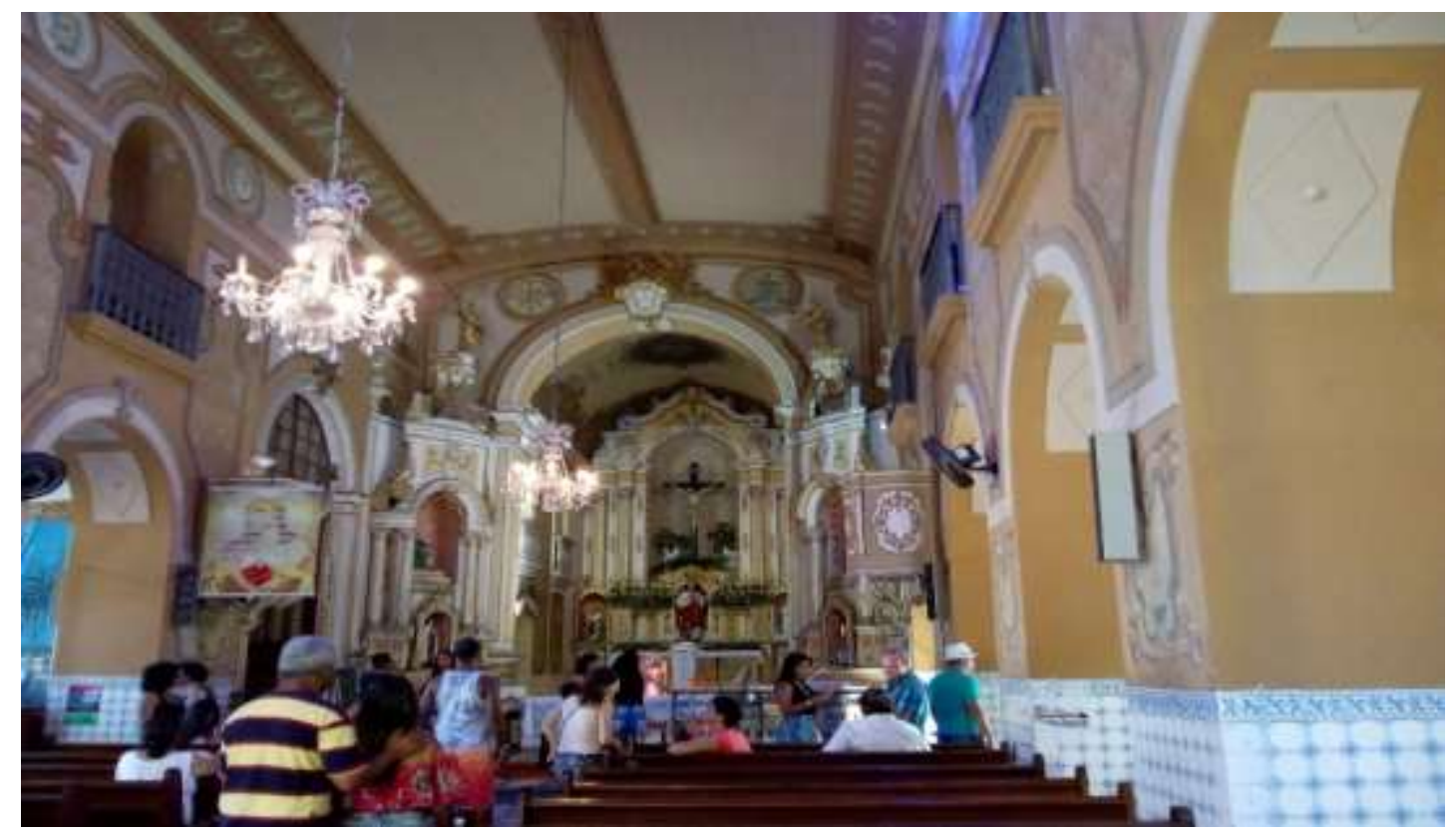

Procissão de Nossa Senhora da Conceição dos Pardos. Fonte: Valéria Alves, 2018.

\section{Taieiras}

Taieiras são grupos formados em sua maioria por mulheres (geralmente de características afrodescendentes), que dançam e cantam predominantemente em homenagem a São Benedito e Nossa Senhora do Rosário. A primeira referência às Taieiras é feita por Francisco Calmon, ao descrever a festa realizada na vila de Nossa Senhora da Purificação e Santo Amaro, na Bahia, em 1760.

\section{Guerreiros}

Guerreiro é um grupo de dançarinos e cantores semelhante ao reisado (uma tradição relacionada ao Natal), mas com maior número de pessoas, maior riqueza nos trajes e enfeites e mais beleza nas músicas. Surgido em Alagoas entre os anos de 1927 e 1929. 


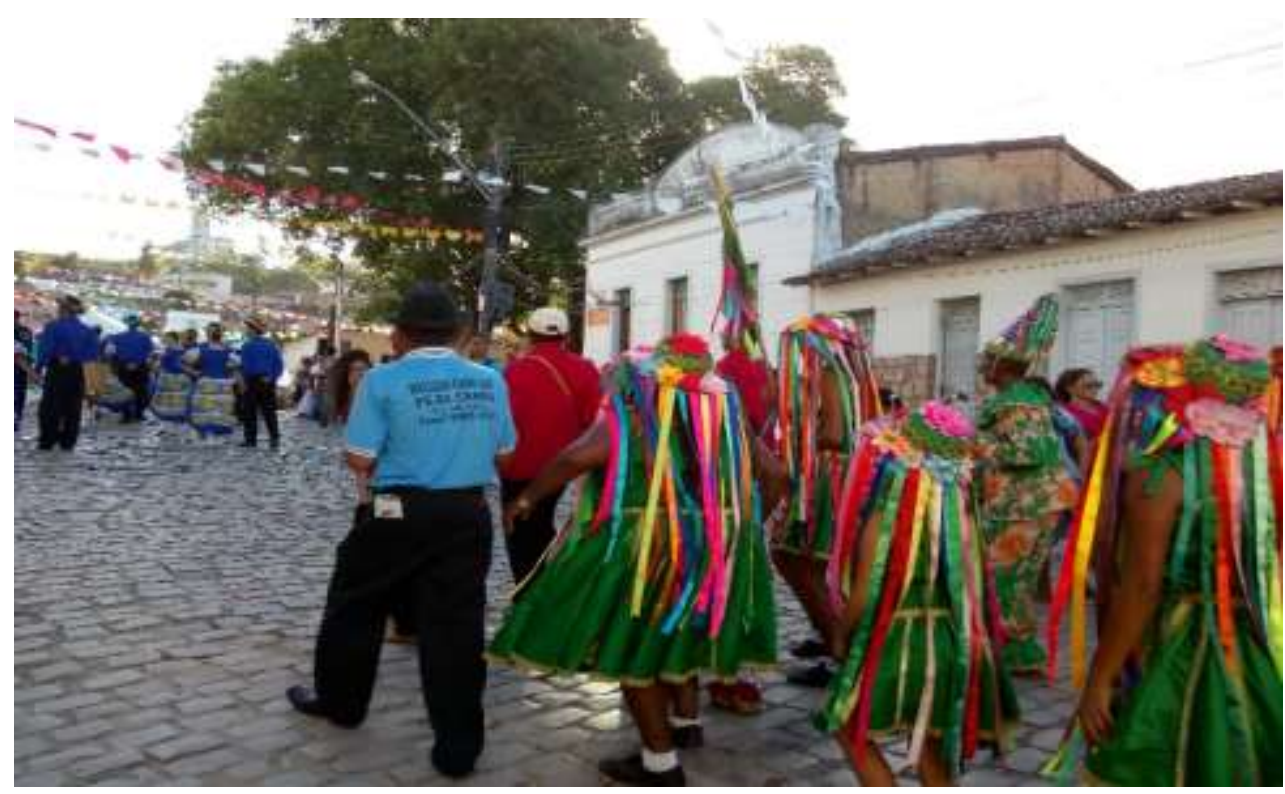

Cortejos de grupos das culturas populares tradicionais. Fonte: Valéria Alves, 2018.

\section{Reisado}

O Reisado se instalou em Sergipe no período colonial. É uma dança do período natalino em comemoração ao nascimento do menino Jesus e em homenagem aos Reis Magos. Antigamente, era dançado às vésperas do Dia de Reis, se estendendo até fevereiro para o ritual do "enterro do boi". Atualmente, o Reisado é dançado também em outros eventos e em qualquer época do ano.

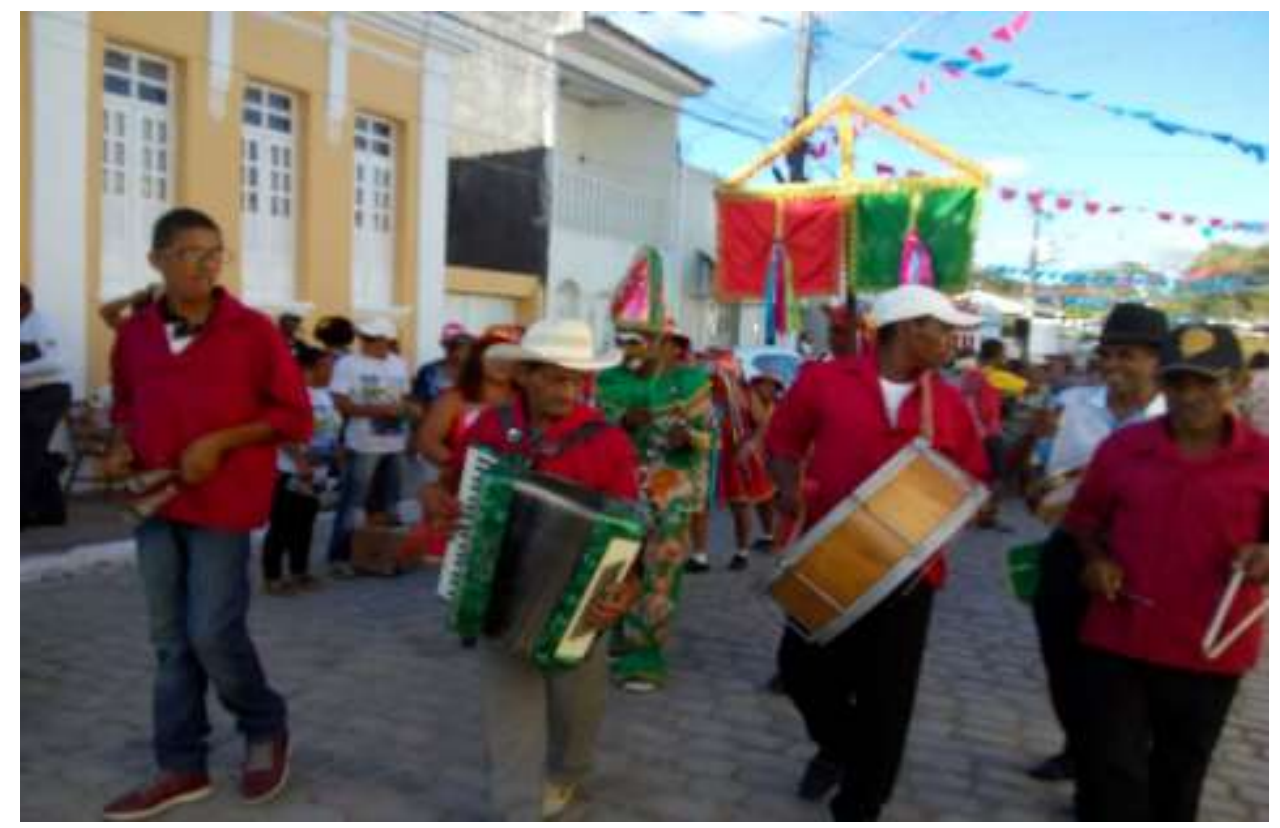

Cortejos de grupos das culturas populares tradicionais. Fonte: Valéria Alves, 2018. 


\section{Cacumbi}

O grupo se apresenta na Procissão de Bom Jesus dos Navegantes e no Dia de Reis, quando a dança é realizada em homenagem a São Benedito e Nossa Senhora do Rosário. Pela manhã, os integrantes do grupo assistem à missa na igreja, onde cantam e dançam em homenagem aos santos padroeiros. Depois das louvações, o grupo sai às ruas cantando músicas profanas e, à tarde, acompanham a procissão pelas ruas da cidade.

Seus personagens são o Mestre, o Contramestre e os dançadores e cantadores; o grupo é composto exclusivamente por homens.

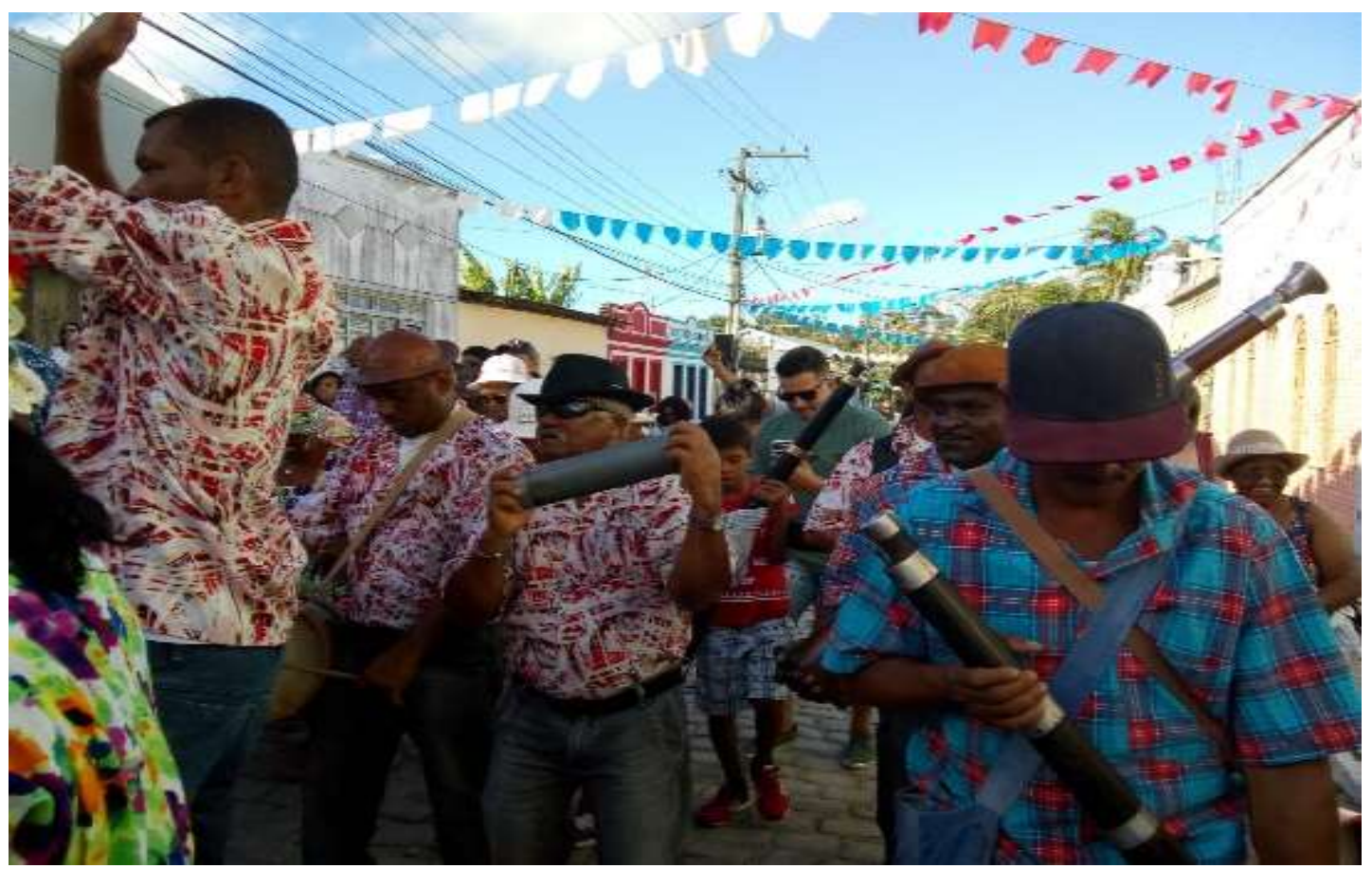

Cortejos de grupos das culturas populares tradicionais. Fonte: Valéria Alves, 2018.

\section{Samba de Pareia}

Em Mussuca, uma das comunidades locais, diz-se que ninguém é "ruim da cabeça", tampouco "doente do pé". Todos ali nasceram e se criaram no samba. A comunidade mantém vive uma das raízes do samba, com tradições que começaram nos canaviais, entre os escravizados da lavoura, e não se perderam com tempo. O Samba de Pareia é uma das ricas manifestações afro-brasileiras, de identidade nacional e sergipana. 


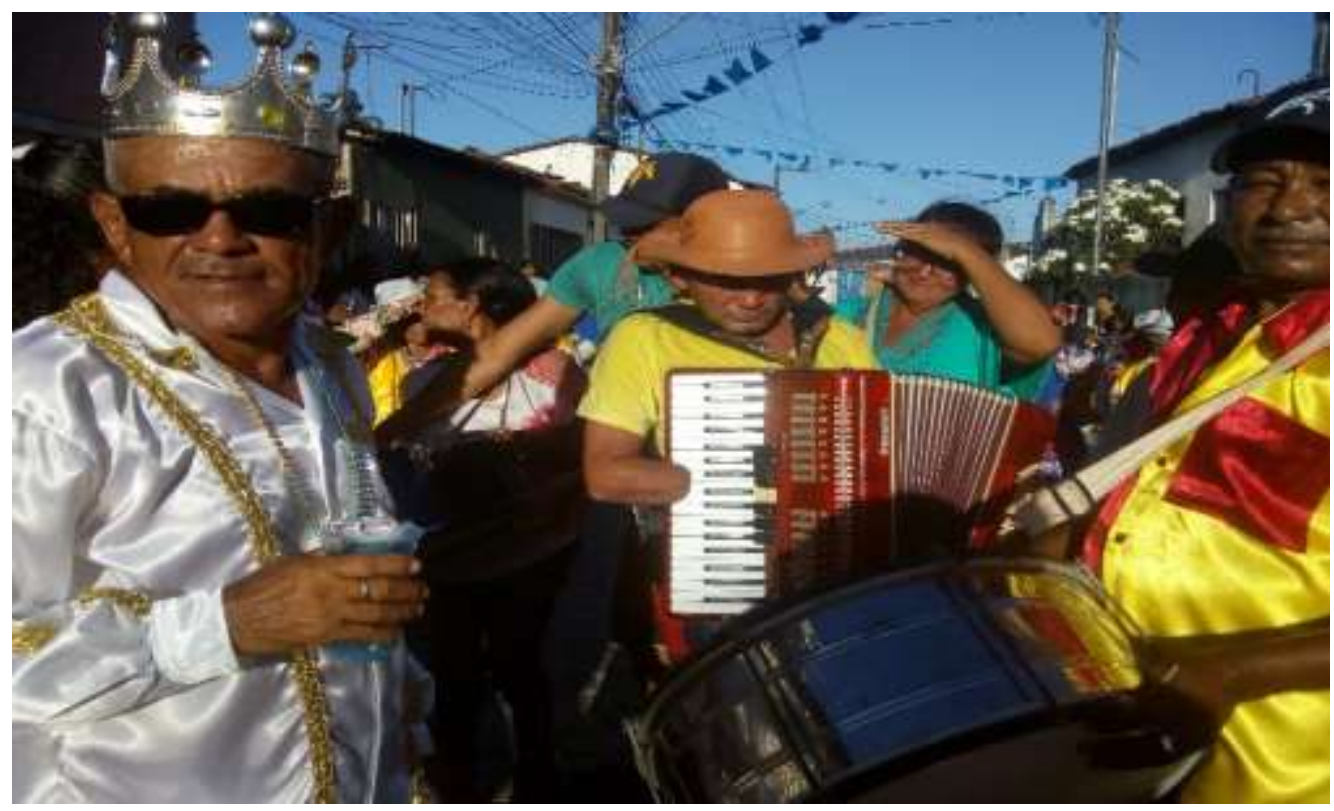

Cortejos de grupos das culturas populares tradicionais. Fonte: Valéria Alves, 2018.

\section{Chegança Almirante Tamandaré}

Datada do século XVII, dança que representa em sua evolução a luta dos cristãos pelo batismo dos Mouros. A apresentação sempre acontece na porta de igrejas, onde uma embarcação de madeira é montada para o desenvolvimento das jornadas. predominância é das cores azul e do branco nas vestes. O padre, o rei e os Mouros (personagens da Chegança), utilizam outras tonalidades.

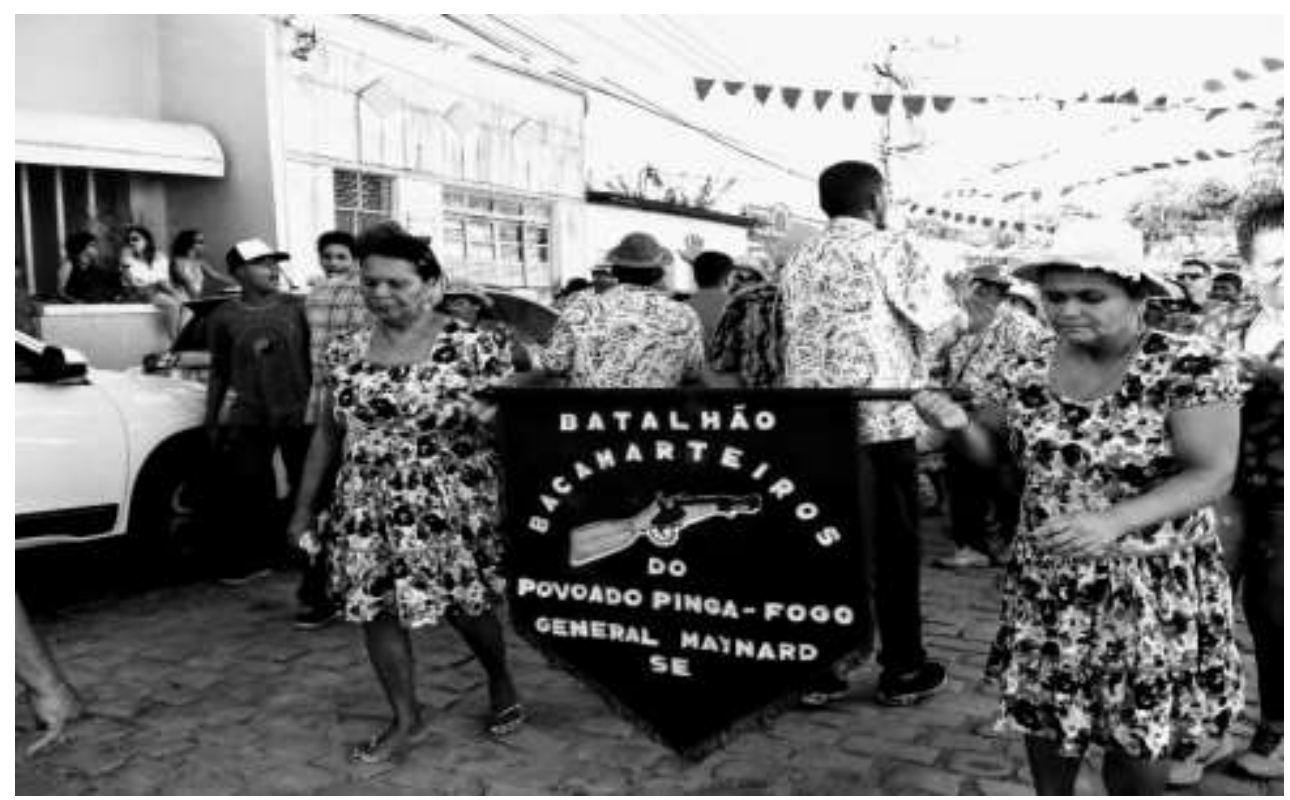

Cortejos de grupos das culturas populares tradicionais. Fonte: Valéria Alves, 2018. 


\section{Samba de Coco}

O samba de coco surgiu na região do nordeste e o ritmo possui traços indígenas, com nítida influência africana. Os negros cantavam durante o ritual da quebra do coco para a extração das coconhas.

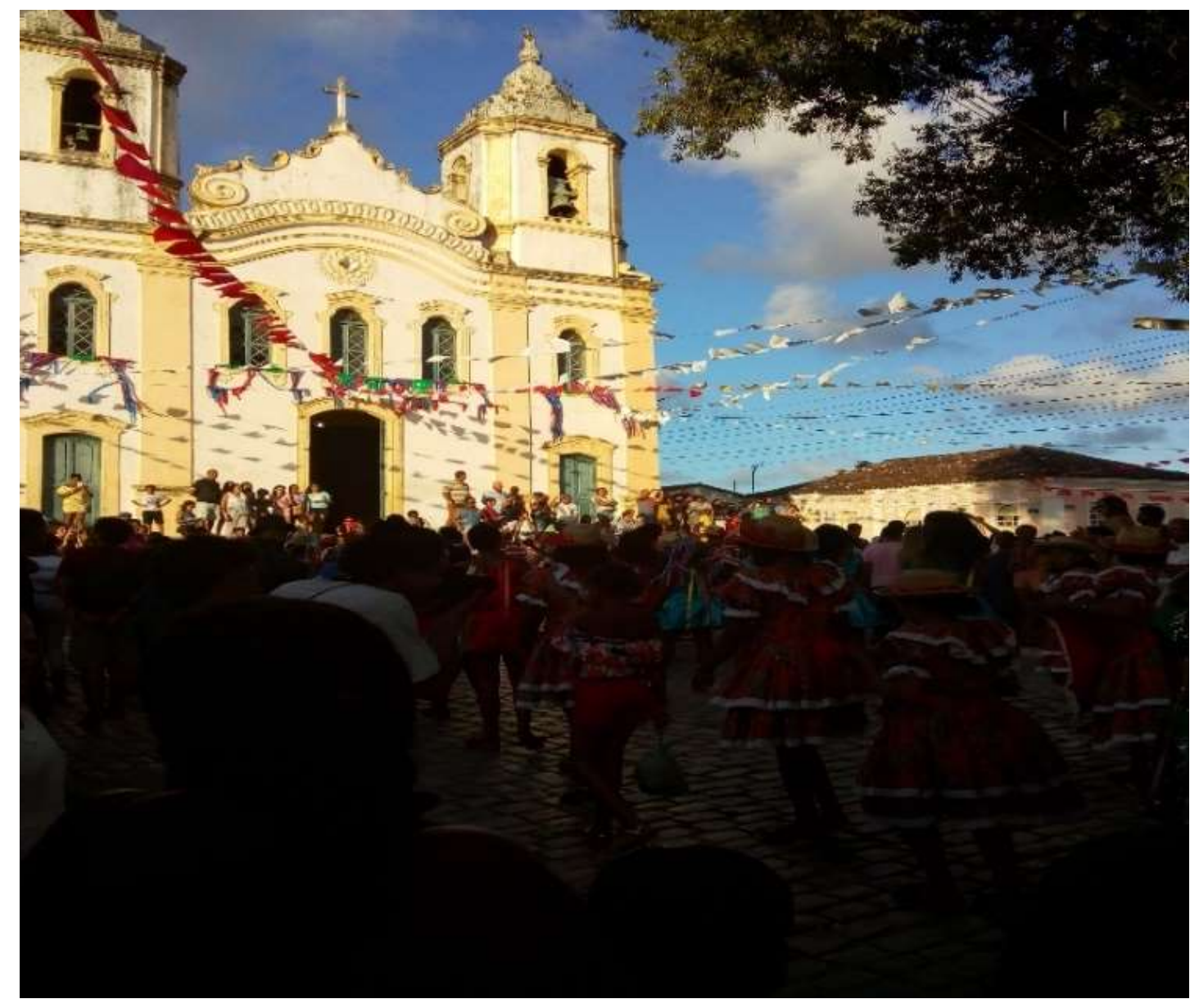

Cortejos de grupos das culturas populares tradicionais. Fonte: Valéria Alves, 2018. 


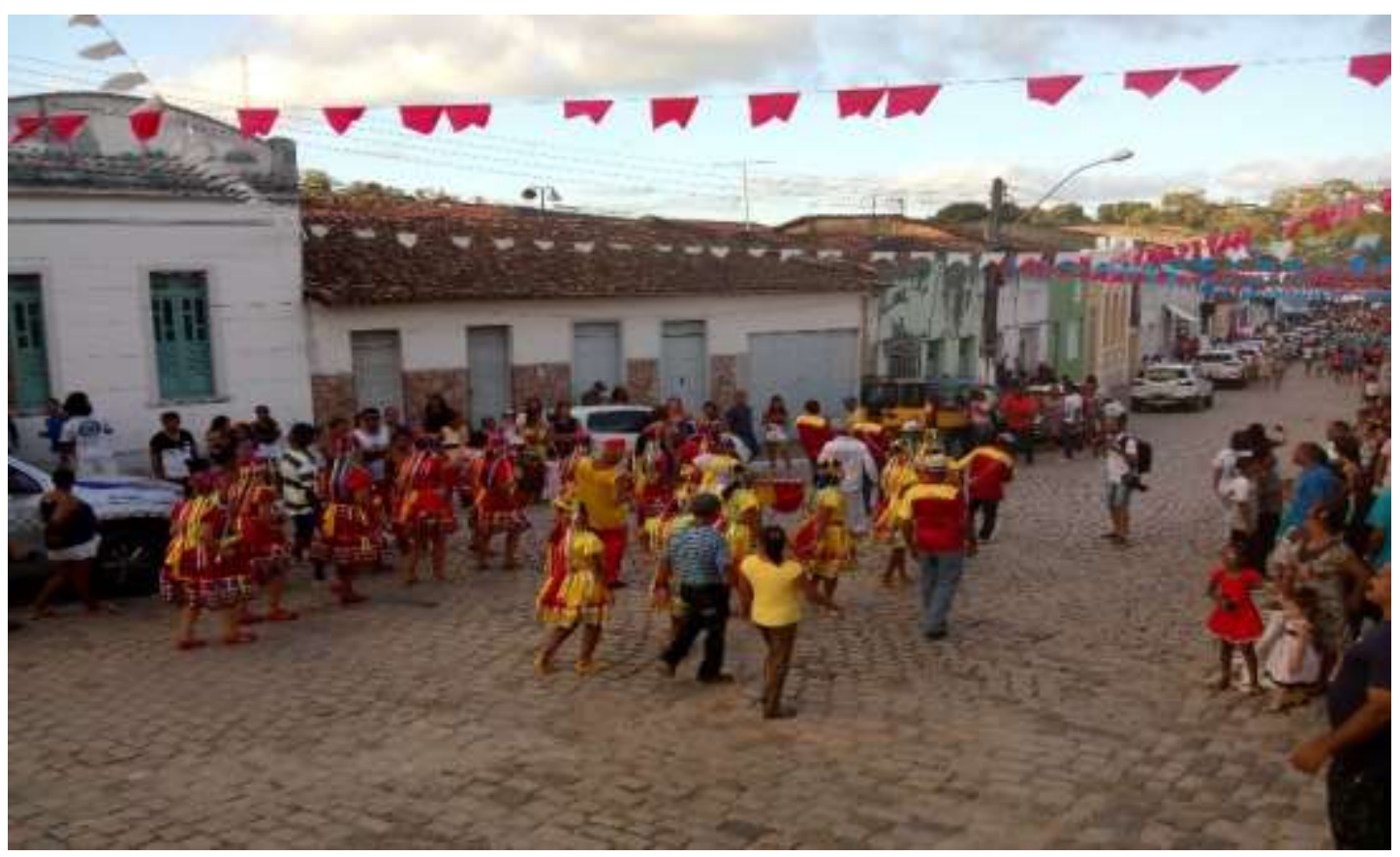

Cortejos de grupos das culturas populares tradicionais. Fonte: Valéria Alves, 2018.

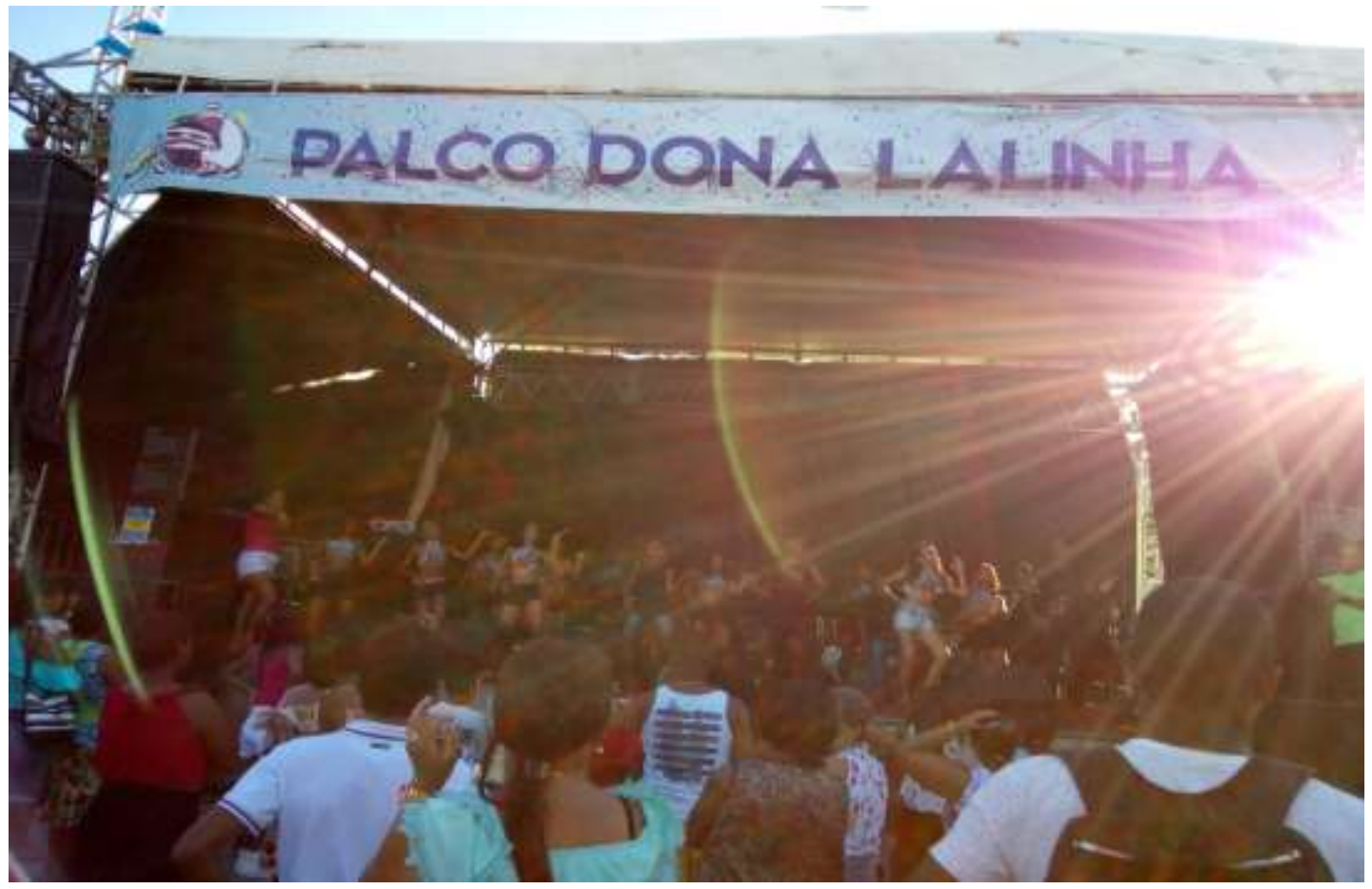

Circulação de citadinos e turistas no festival. Fonte: Valéria Alves, 2018. 


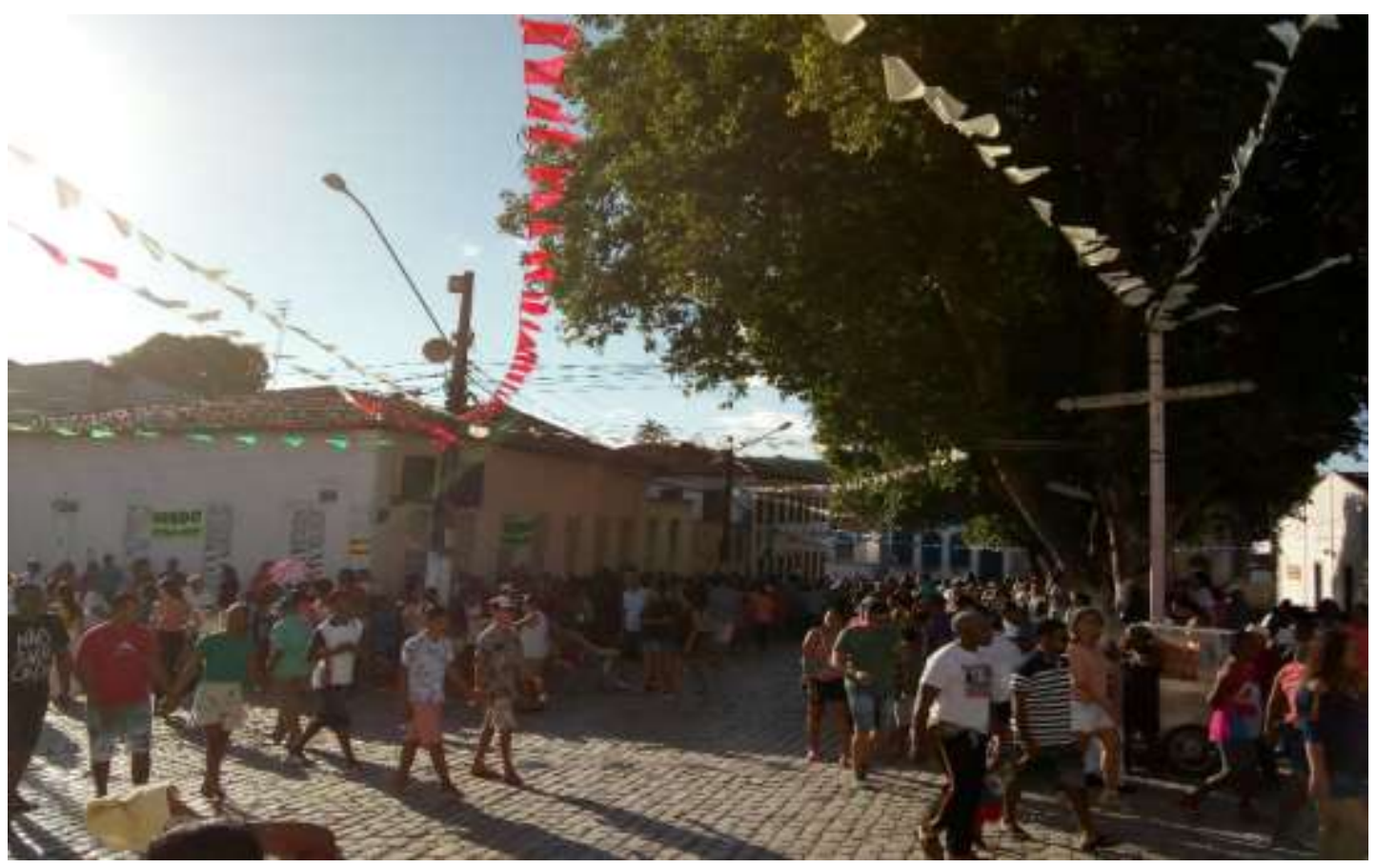

Circulação de citadinos e turistas durante o festival. Fonte: Valéria Alves, 2018.

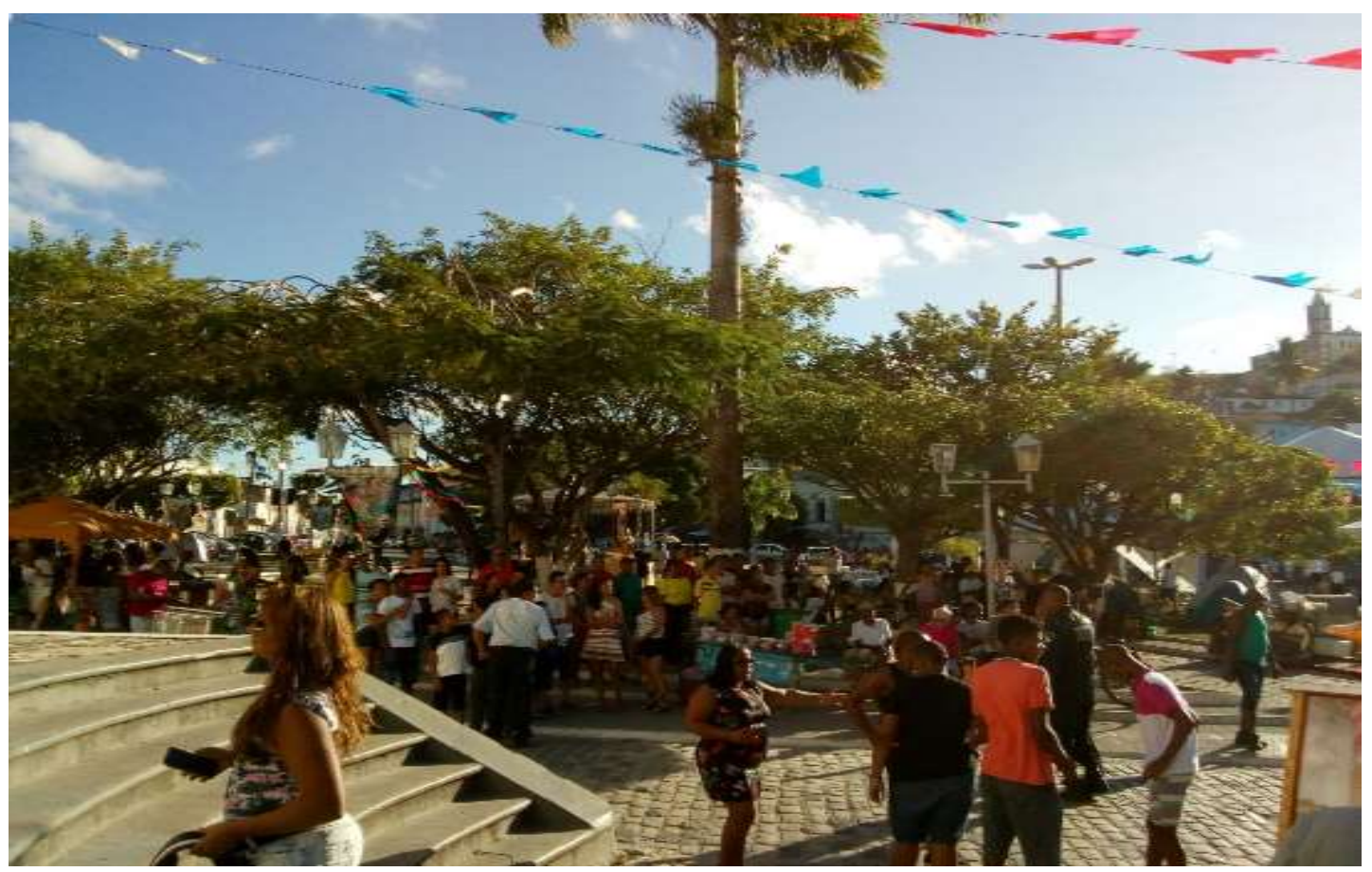

Circulação de citadinos e turistas no festival Fonte: Valéria Alves, 2018. 


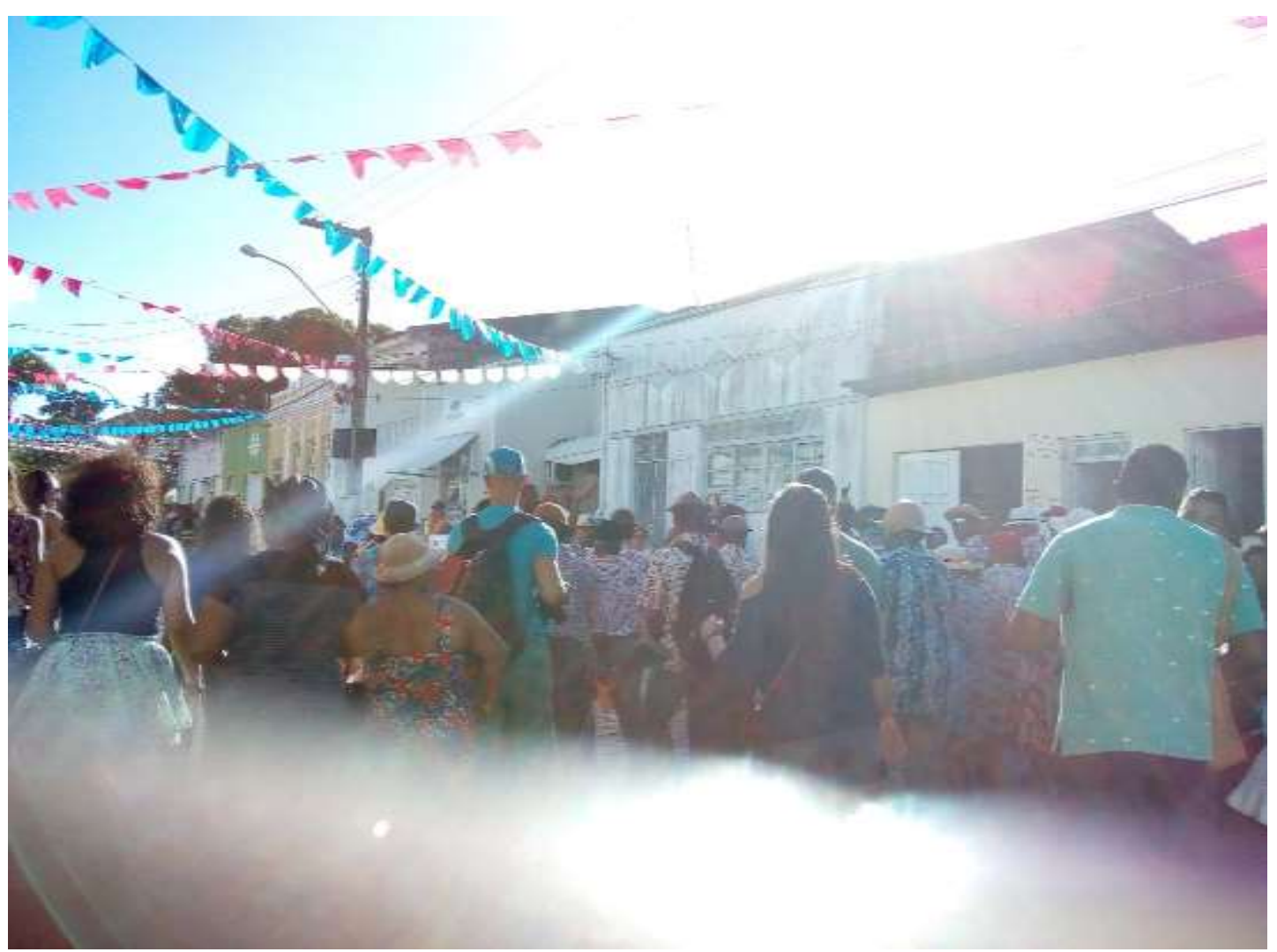

Circulação de citadinos e turistas no festival. Fonte: Valéria Alves, 2018.

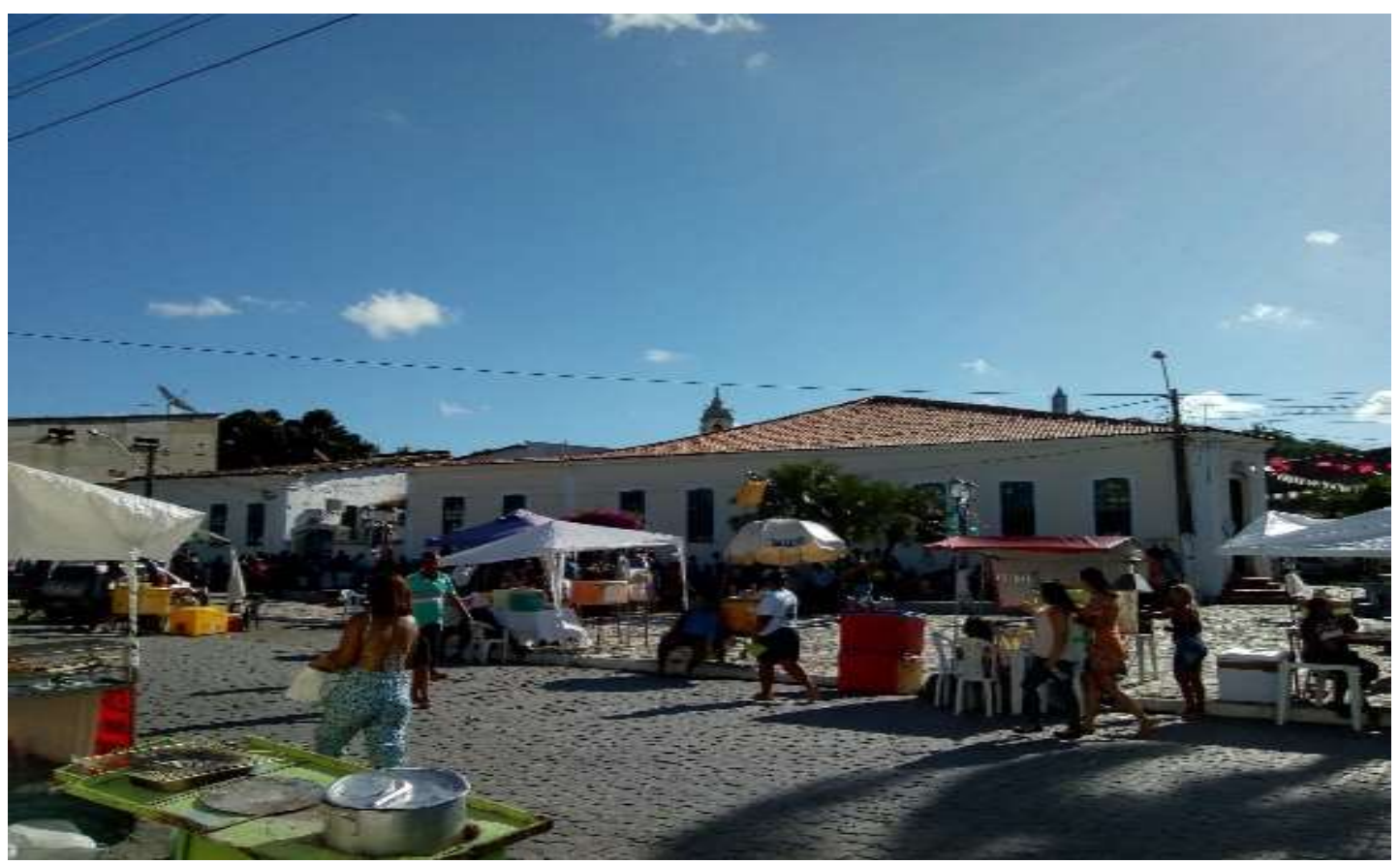

Circulação de citadinos e turistas no festival. Fonte: Valéria Alves, 2018. 


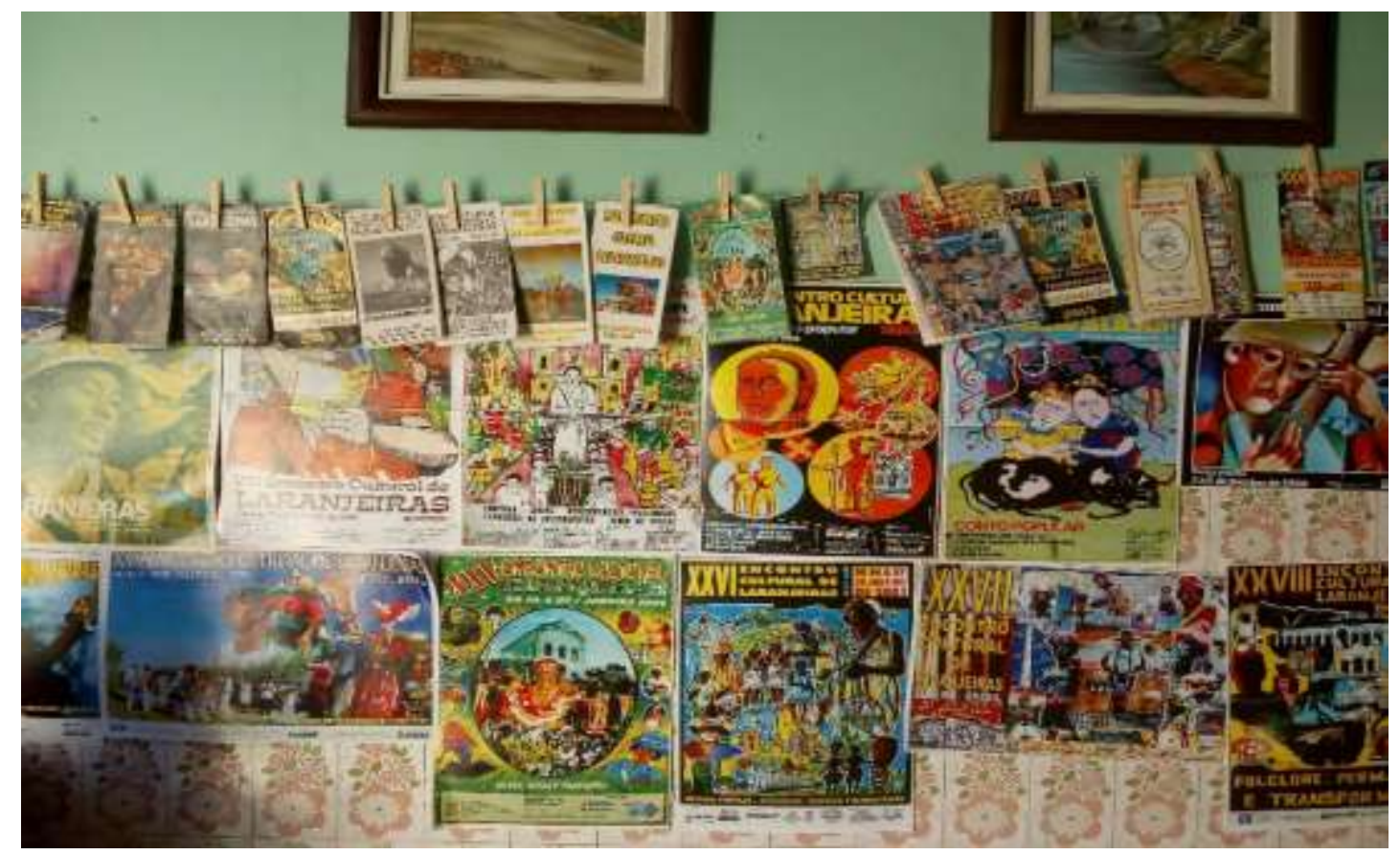

Casa de Cultura Oscar Ribeiro e Exposição dos cartazes dos últimos 17 festivais. Fonte: Valéria Alves, 2018.

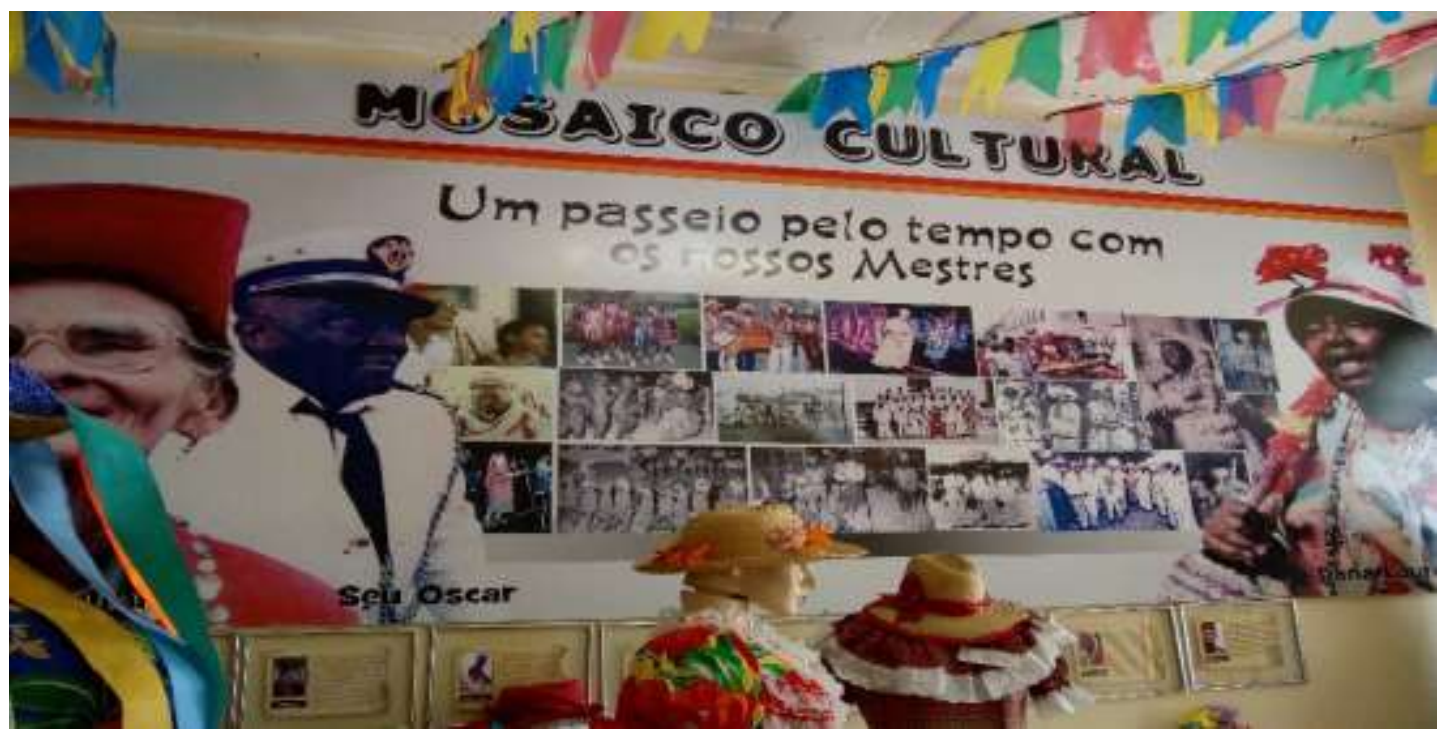

Casa de Cultura Oscar Ribeiro e Exposição dos cartazes dos últimos 17 festivais. Fonte: Valéria Alves, 2018. 


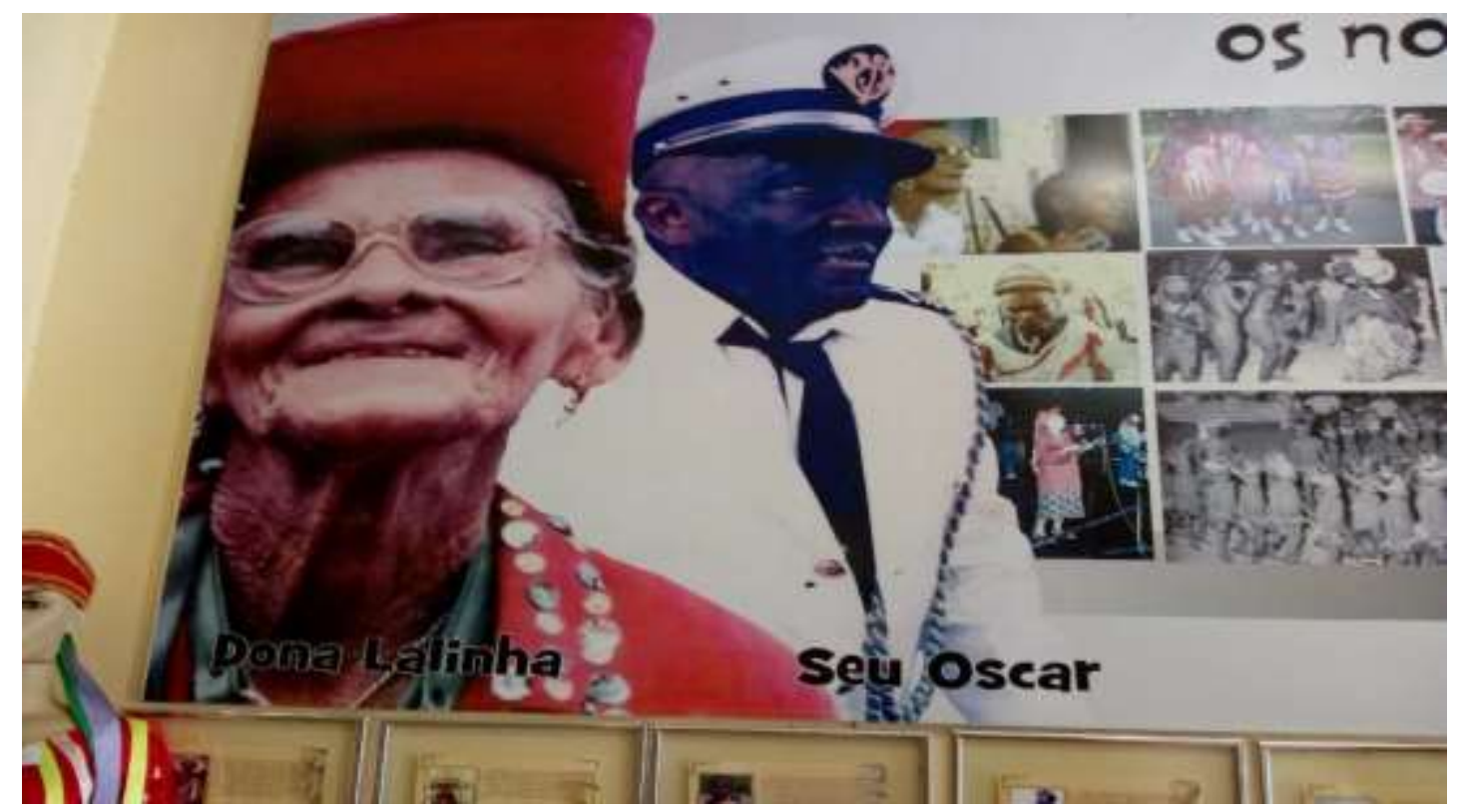

Casa de Cultura Oscar Ribeiro e Exposição dos cartazes dos últimos 17 festivais. Fonte: Valéria Alves, 2018.

\section{Museu Afro Brasileiro}

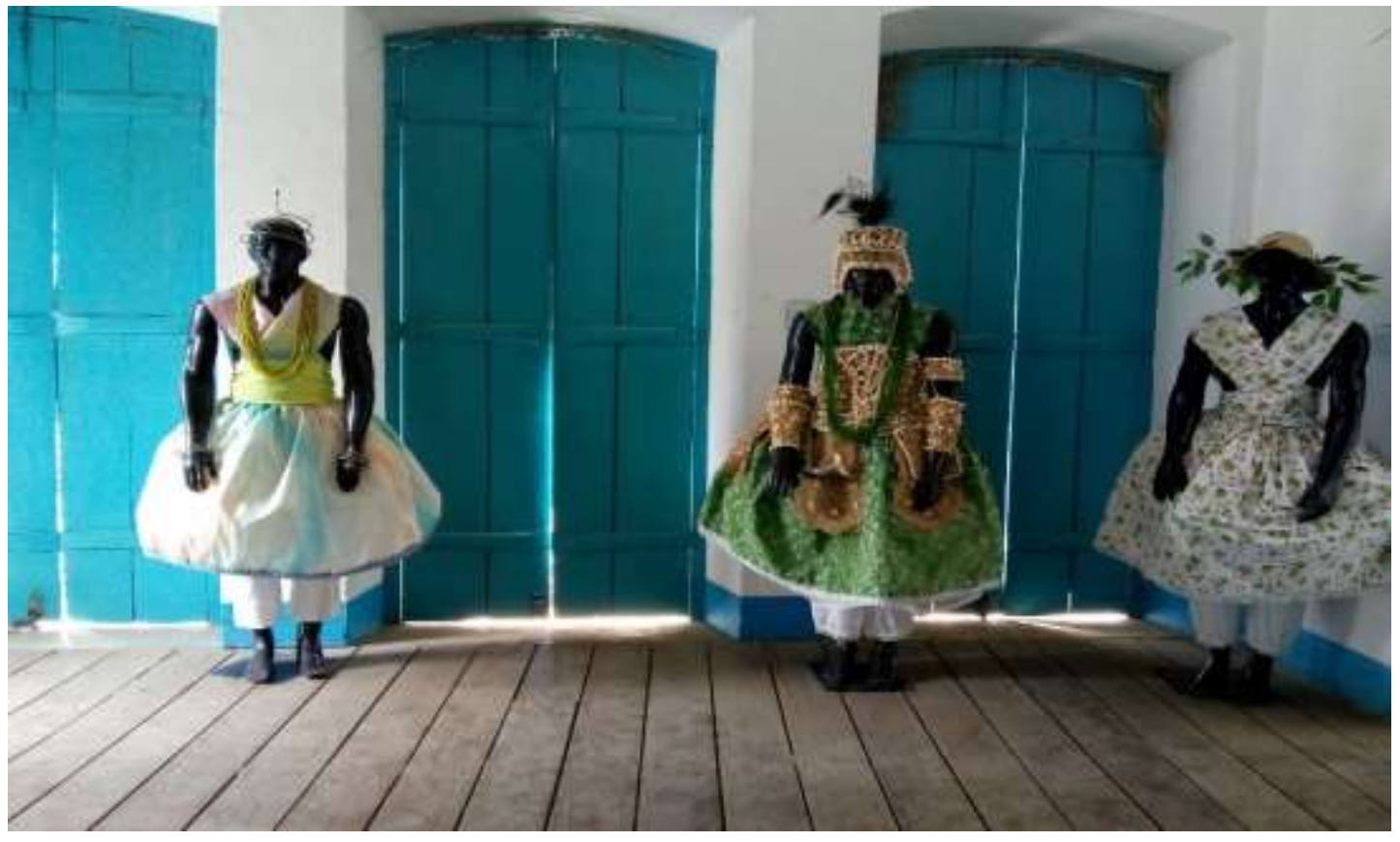

Museu Afro Brasileiro. Fonte: Valéria Alves, 2018. 


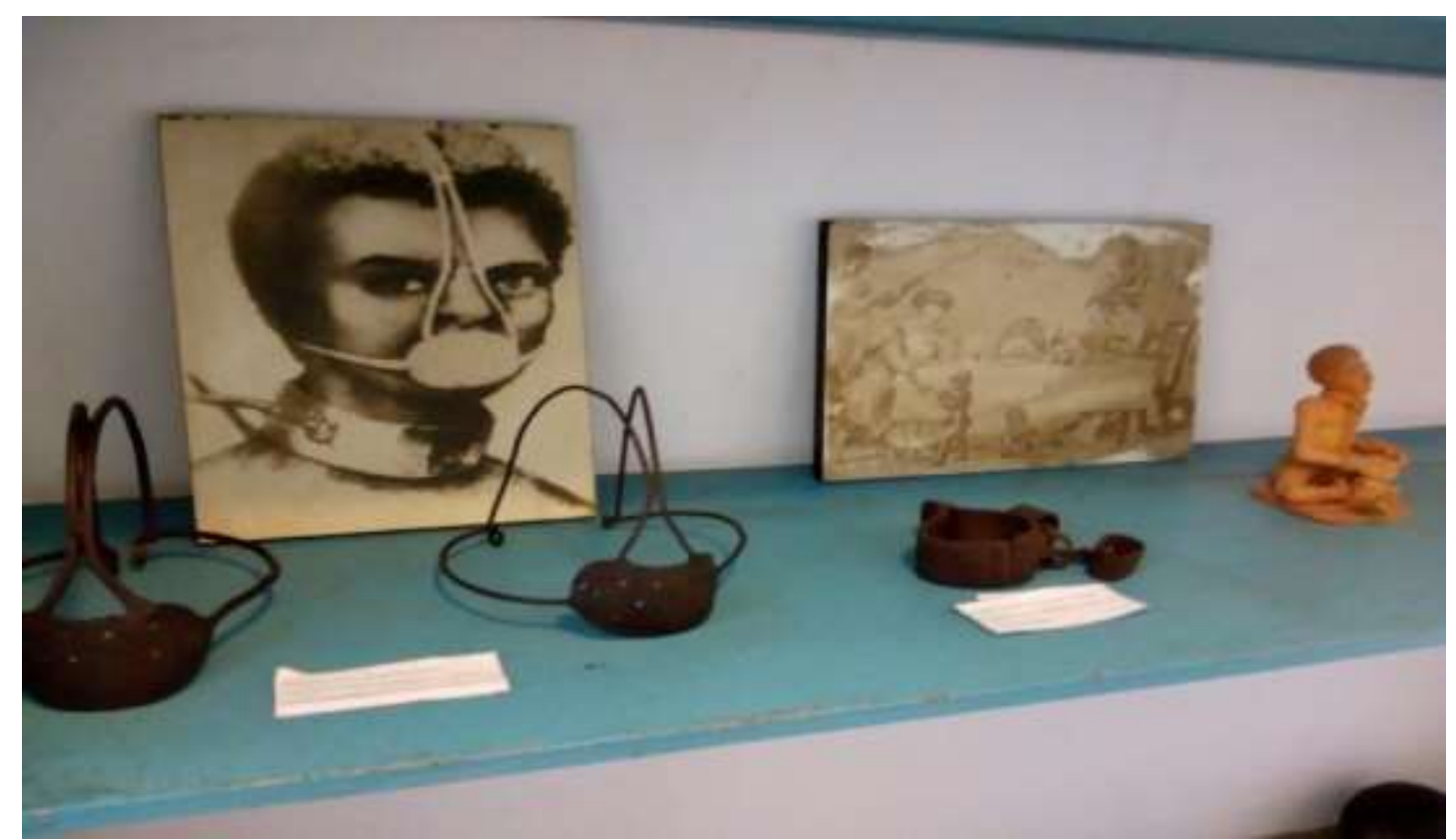

Museu Afro Brasileiro. Fonte: Valéria Alves, 2018.

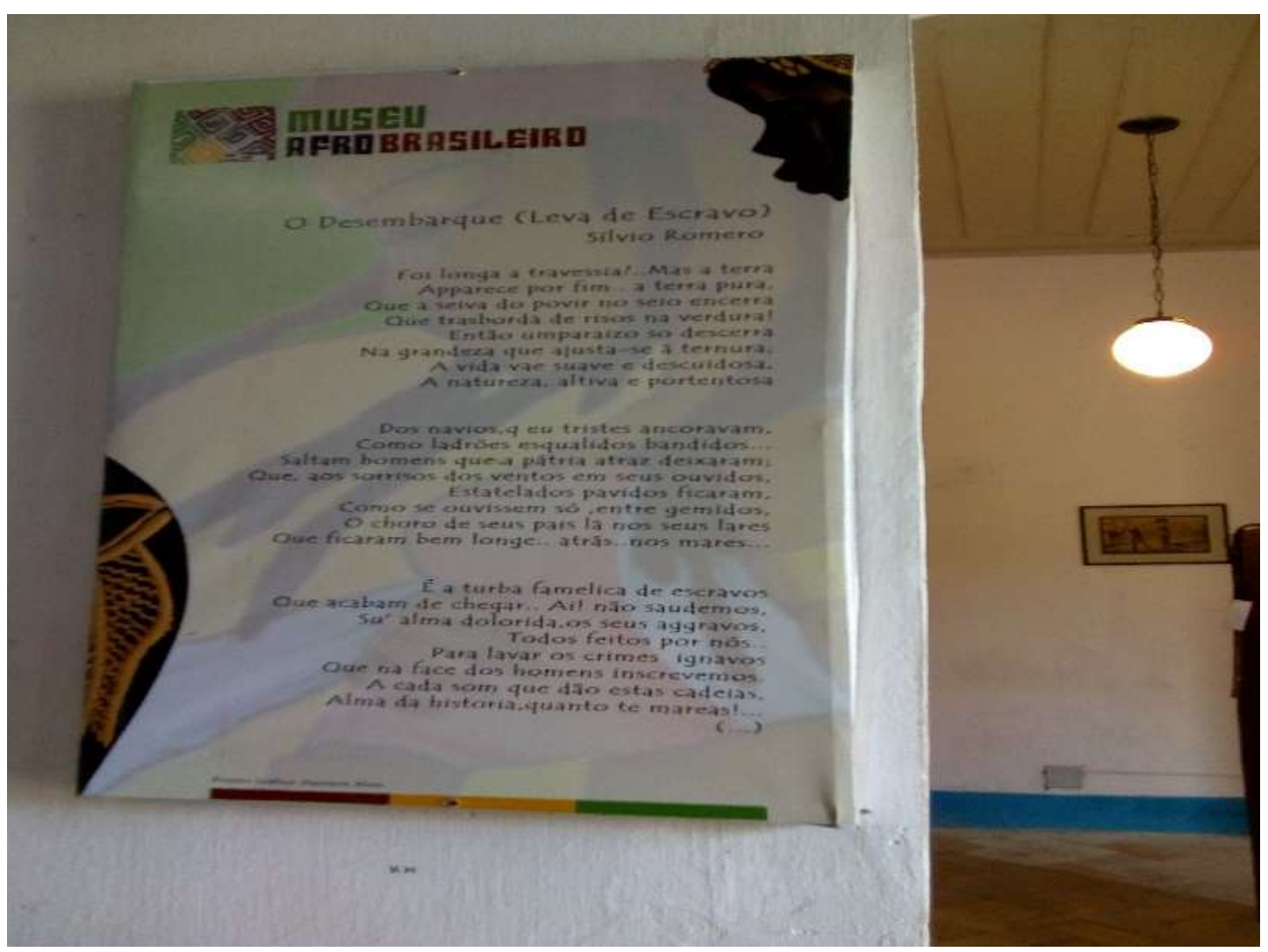

Museu Afro Brasileiro. Fonte: Valéria Alves, 2018. 


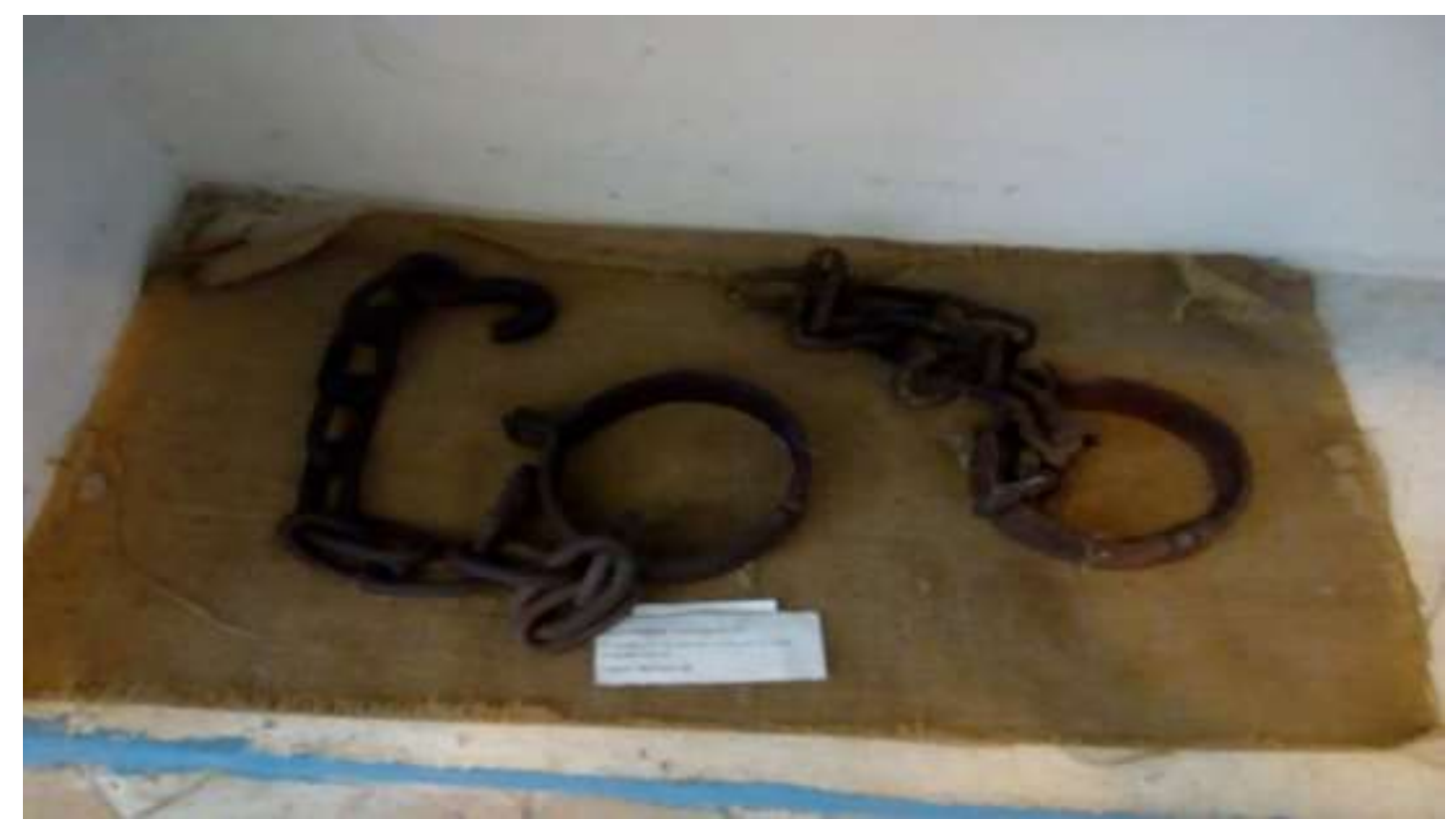

Museu Afro Brasileiro. Fonte: Valéria Alves, 2018.

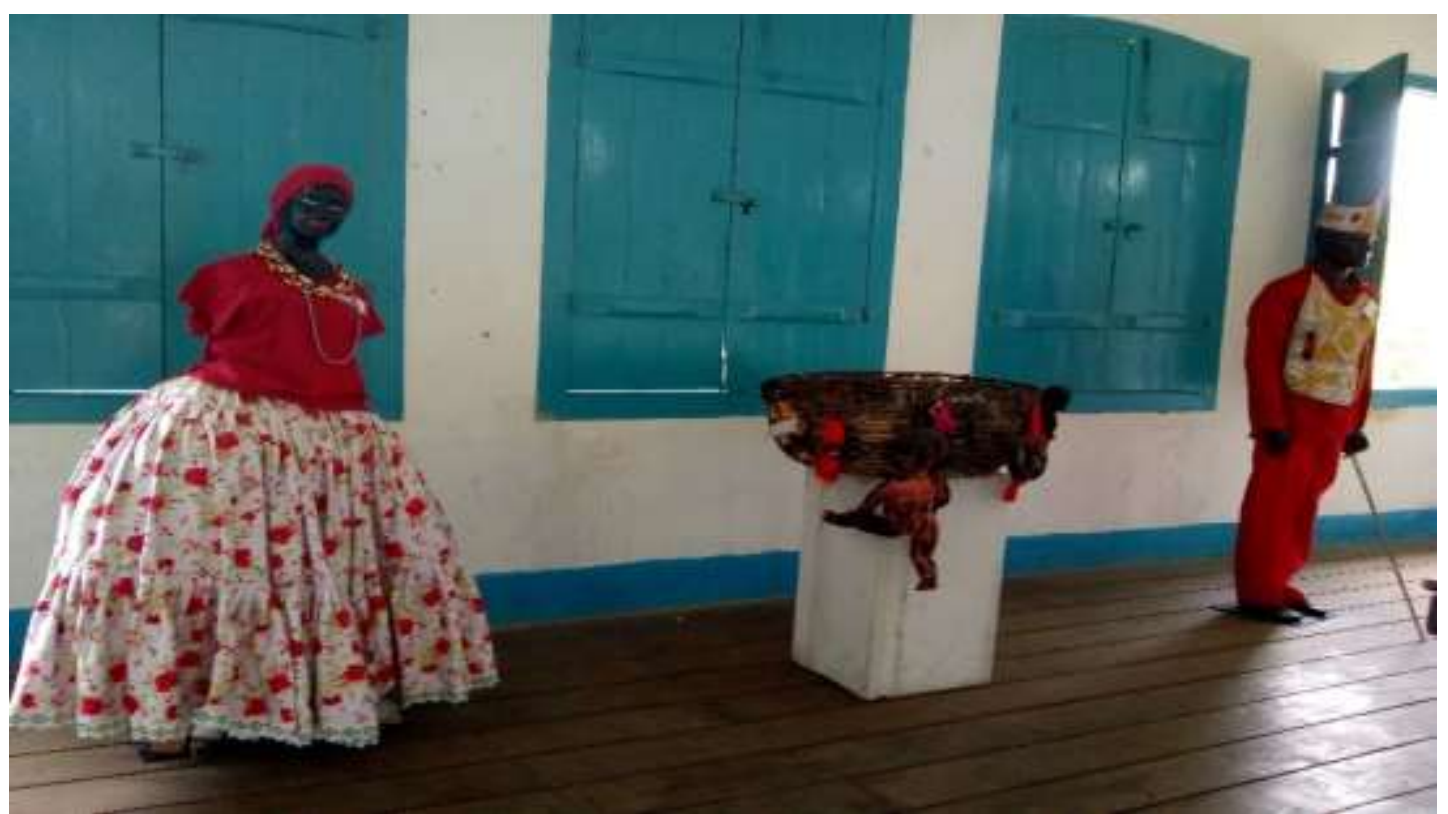

Museu Afro Brasileiro. Fonte: Valéria Alves, 2018. 


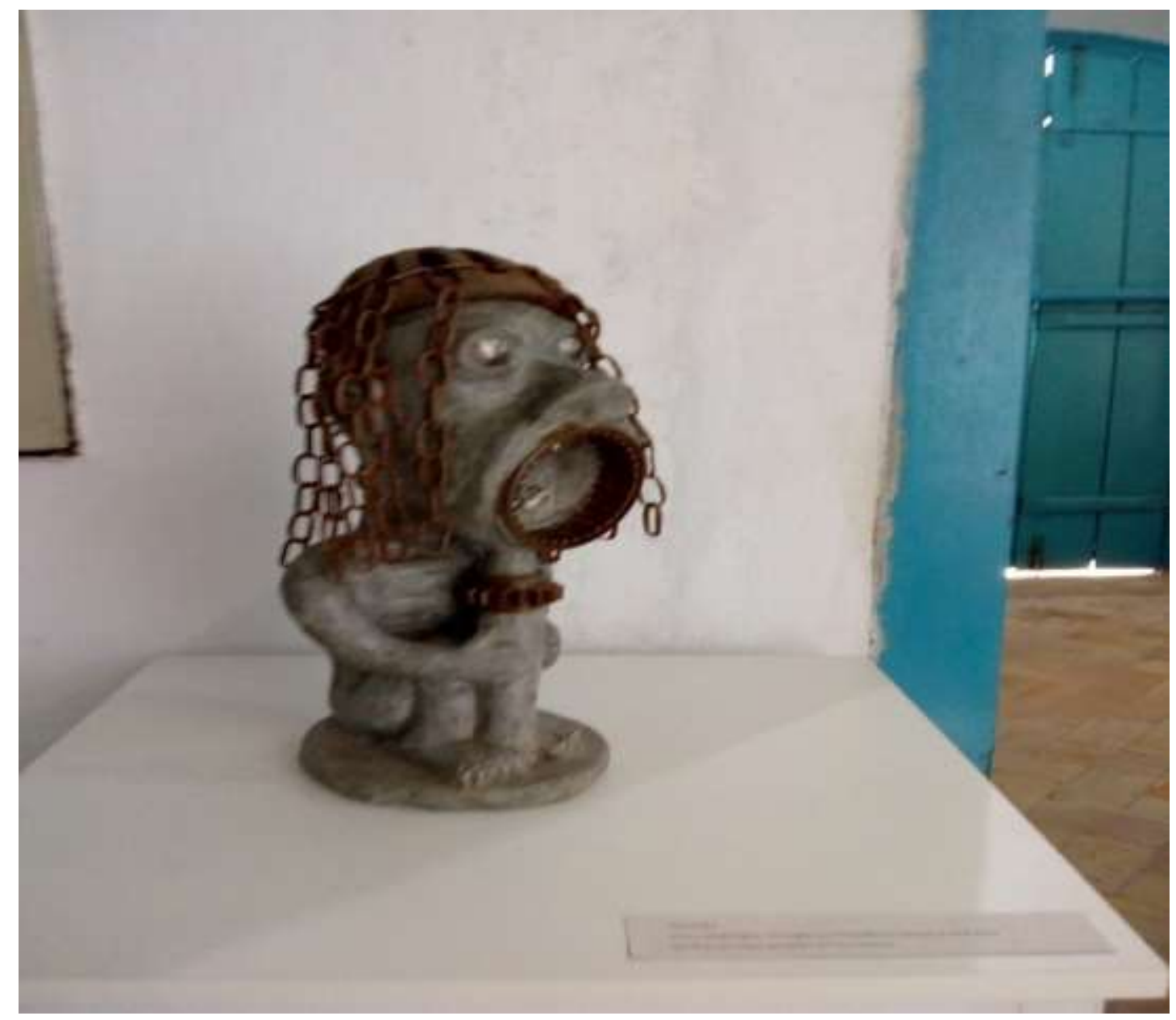

Museu Afro Brasileiro. Fonte: Valéria Alves, 2018.

O Encontro Cultural de Laranjeiras é o maior evento em investimentos e apresentações culturais e é muito frequentado por turistas. Existem outras duas manifestações culturais em Laranjeiras que são preparadas, esperadas e apreciadas durante o ano todo pela população de todos os credos: a Festa do Lambe Sujo versus Caboclinhos e a Dança de São Gonçalo do Amarante.

\section{Festa do Lambe Sujo versus Caboclinhos}

A Festa do Lambe Sujo versus Caboclinhos é uma das mais antigas de Laranjeiras. Encena a história do município, construída pelos conflitos entre negros, indígenas e brancos. 


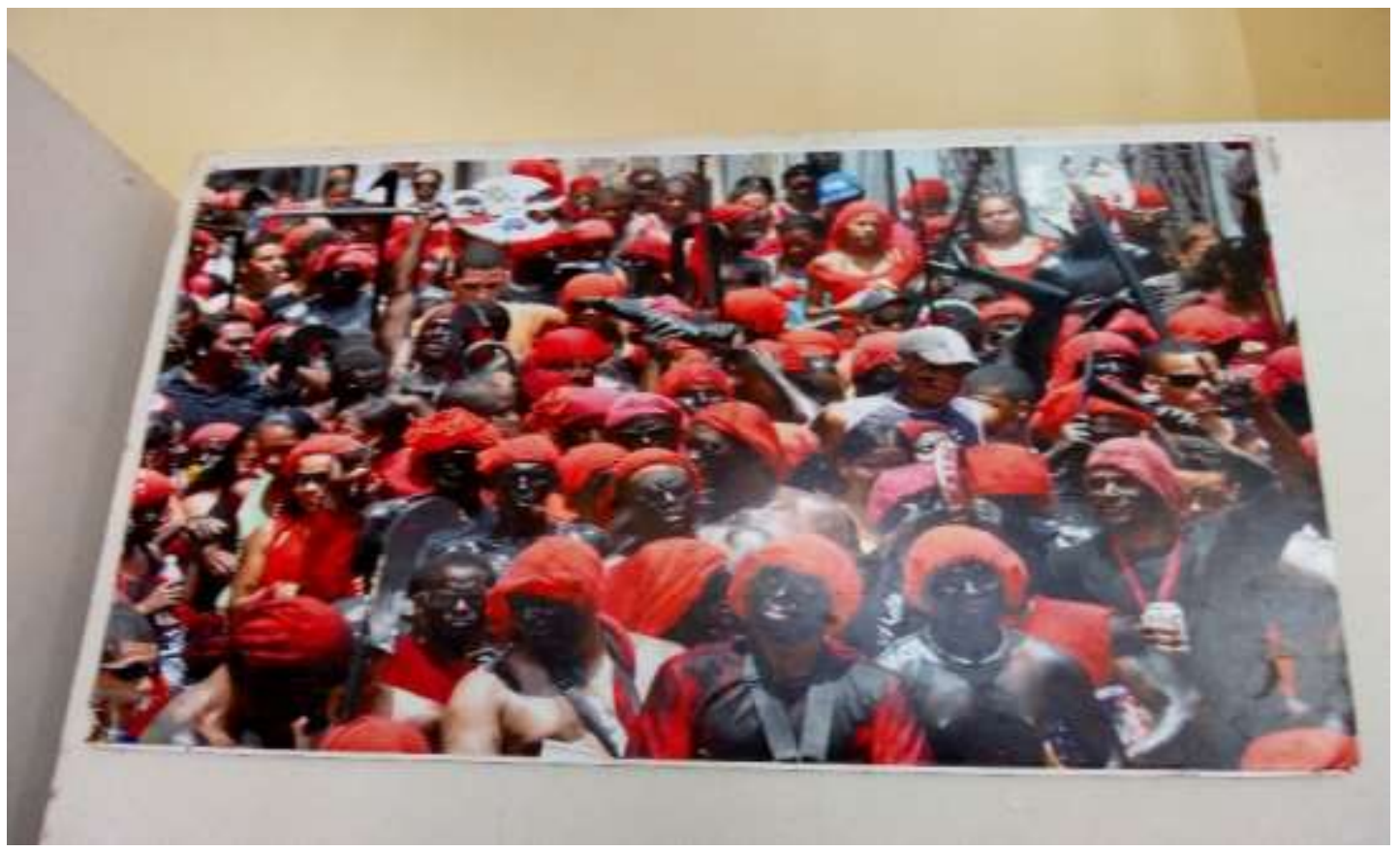

Museu Afro Brasileiro. Fonte: Valéria Alves, 2018.

A festa é uma encenação da luta dos escravizados que, ao fugirem das fazendas, eram caçados e capturados pelos indígenas locais. Uma festa que celebra a derrota dos lambe sujos, os negros, diante da vitória dos indígenas, os caboclinhos (SANTOS, 2009).

Os negros escravizados se refugiavam nas matas e lá construíam suas moradias. Os indígenas, que conheciam bem as matas da região, capturavam os negros em troca de bugigangas e acessórios para enfeitar o corpo.

A festa acontece em outubro, em meio às comemorações cívicas da cidade, como forma de enaltecer e resgatar a memória social, cultural e política: "Considerada como teatro a céu aberto, ocorre há mais de nove décadas, e no decorrer das apresentações durante os dois dias, internalizam e externalizam através de gestos, roupas, falas, indumentárias a luta entre as três raças: o negro, o índio e o branco" (SANTOS, 2009, p.03). O teatro dramatiza a luta dos negros contra os capitães do mato e contra os indígenas, que a mando dos brancos, trabalham para capturá-los. 


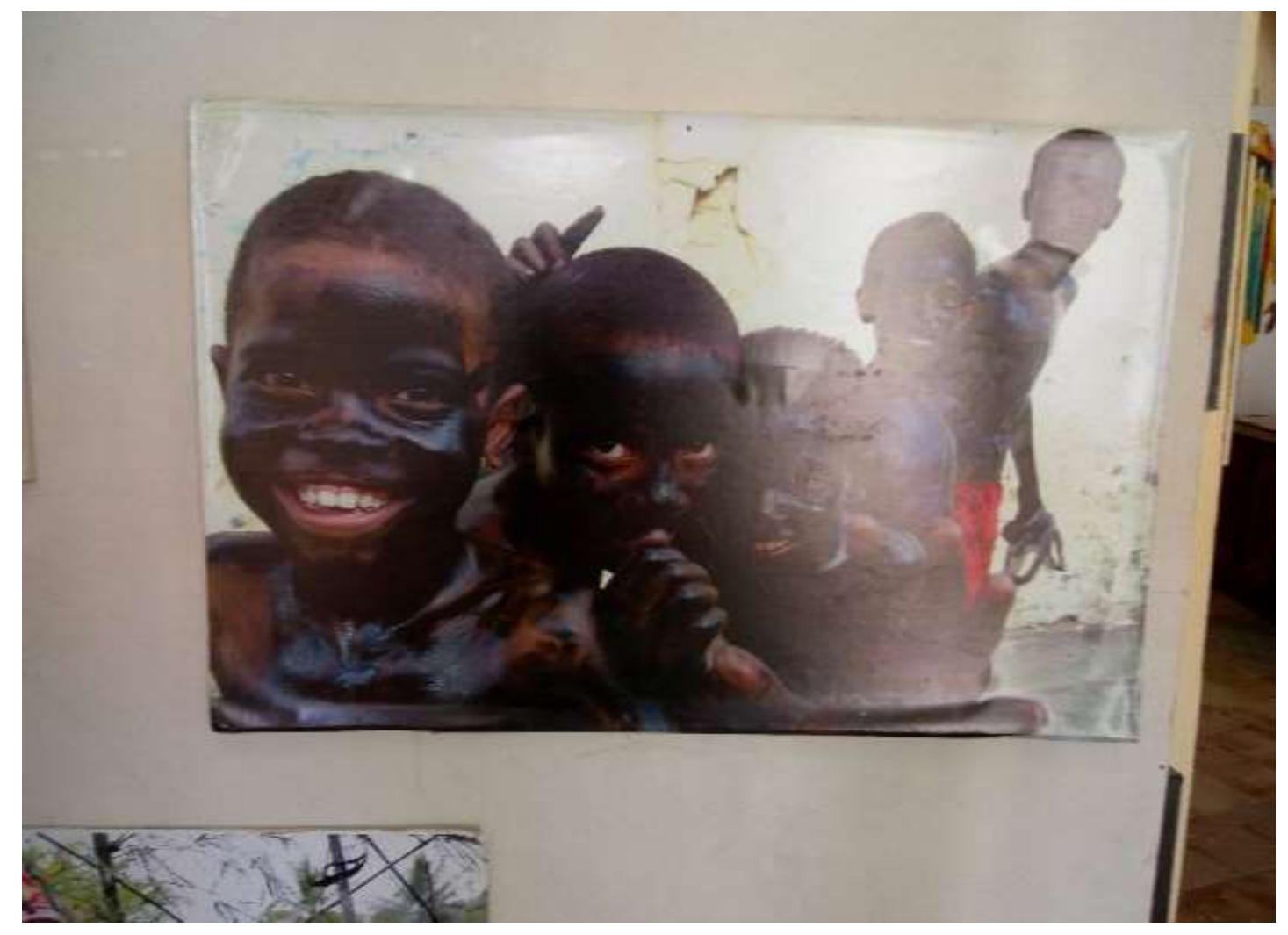

Museu Afro Brasileiro. Fonte: Valéria Alves, 2018.

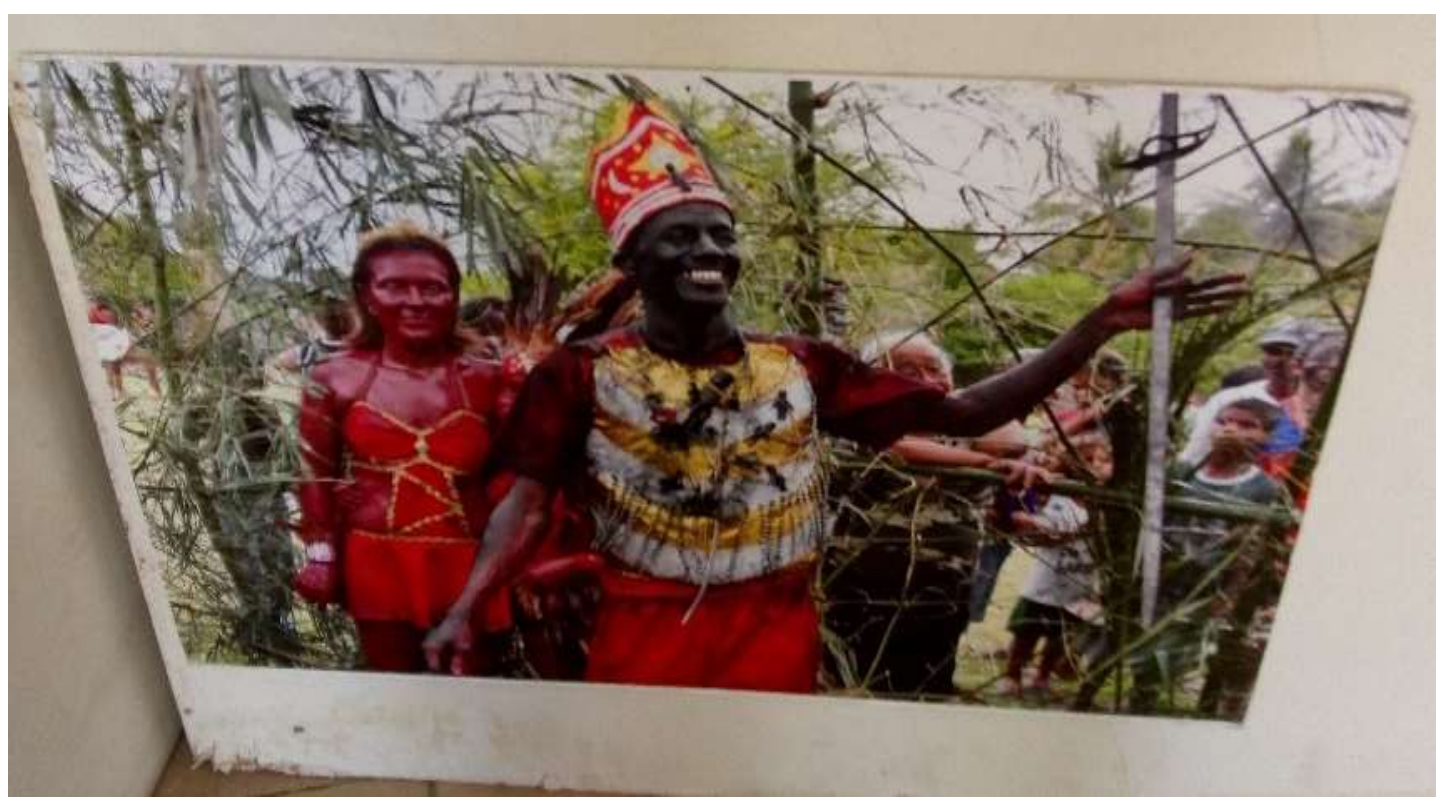

Museu Afro Brasileiro. Fonte: Valéria Alves, 2018. 


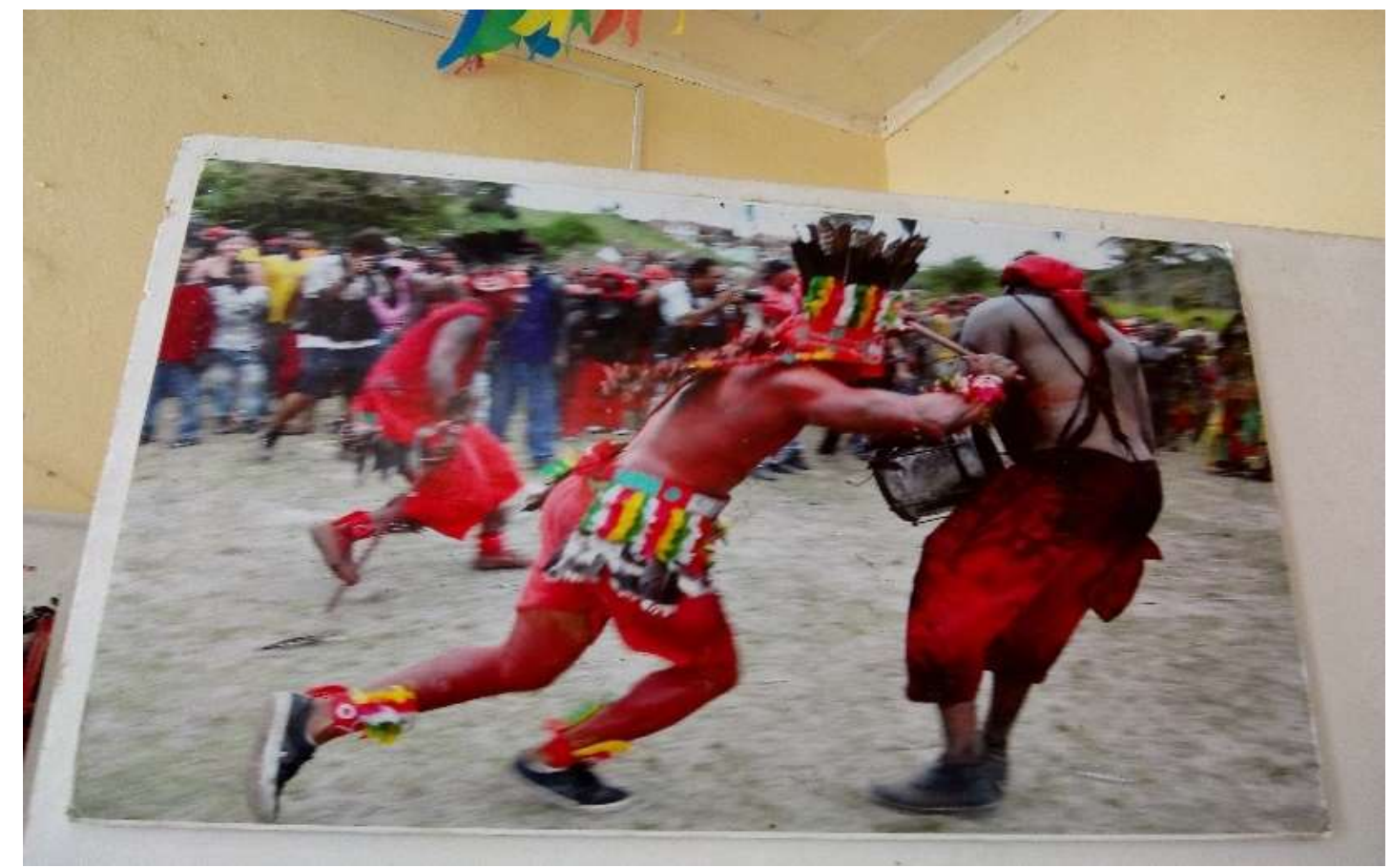

Museu Afro Brasileiro. Fonte: Valéria Alves, 2018.

A narrativa desta festa se estrutura, em alguma medida, numa restauração de conflitos por meio da dramatização, da memória e da reafirmação das identidades locais. Trata-se de um drama social.

\section{Dança de São Gonçalo}

A Dança de São Gonçalo acontece em alguns municípios de Sergipe, no entanto, os estudos sobre esta dança estão concentrados no povoado de Mussuca, também chamado Quilombo do Mussuca. 


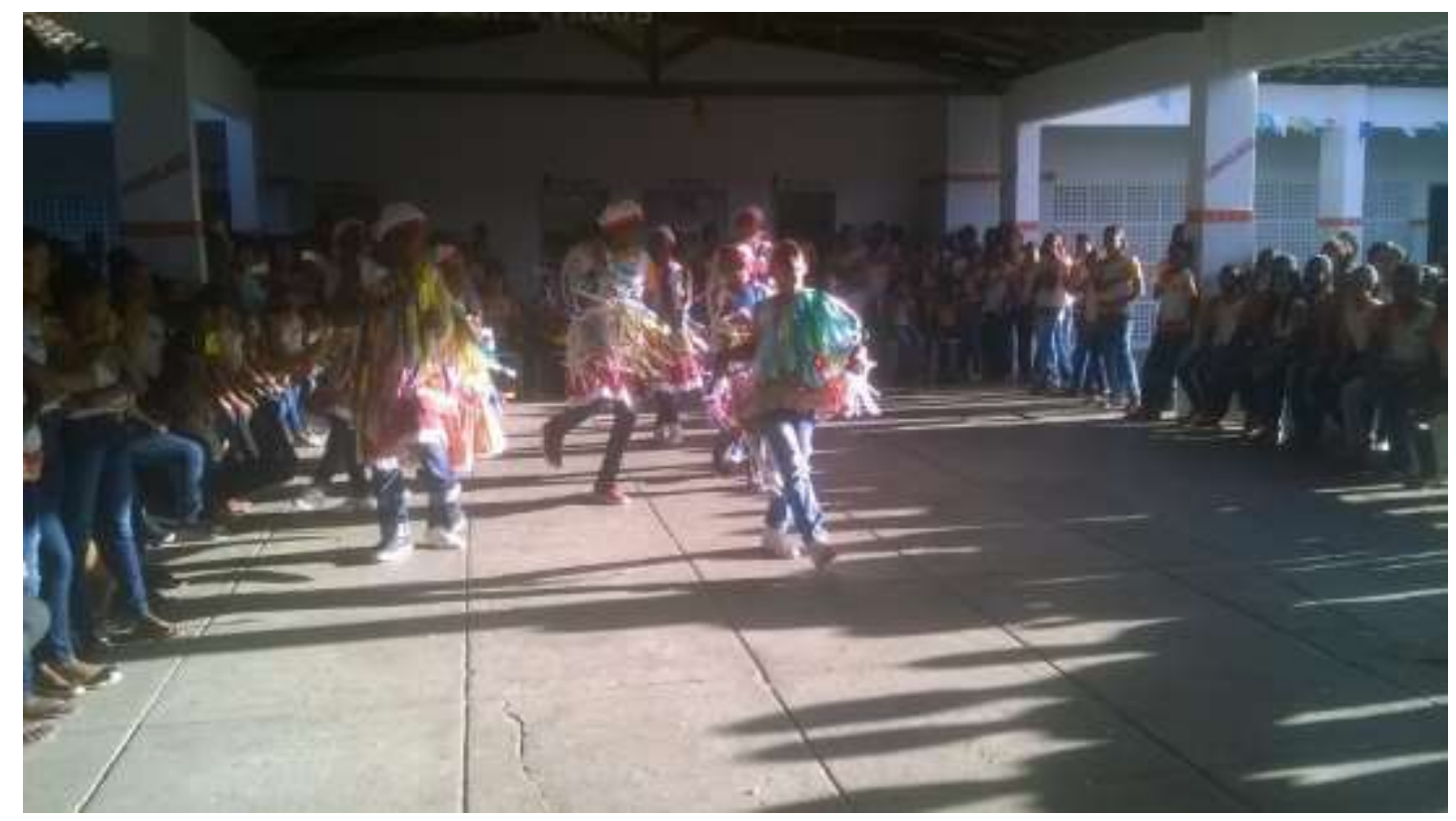

Apresentação da Dança de São Gonçalo pelos estudantes da EM José Manteiro Sobral no Quilombo do Mussuca. Fonte: Valéria Alves, 2017.

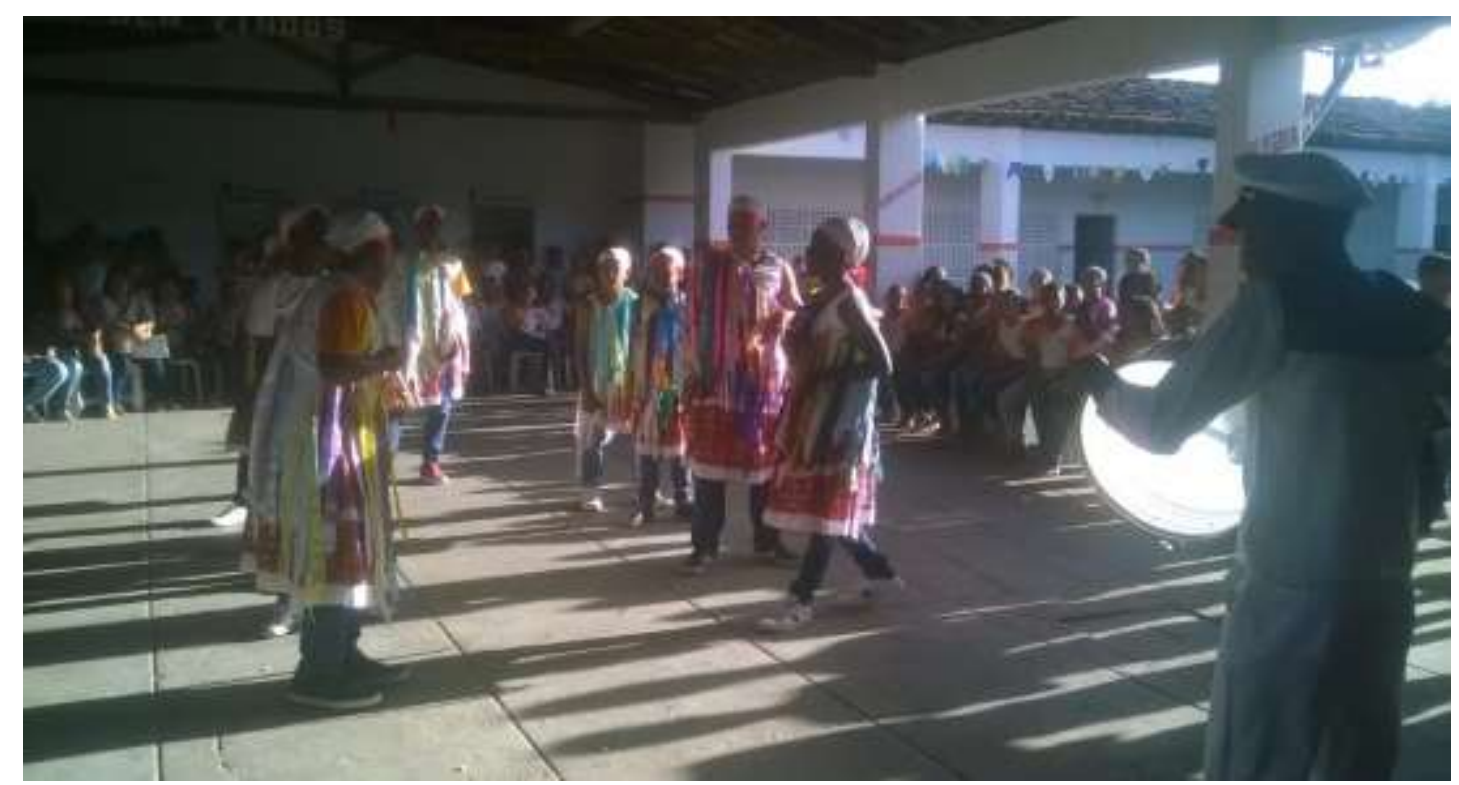

Dança de São Gonçalo no Quilombo do Mussuca. Fonte: Valéria Alves, 2017. 


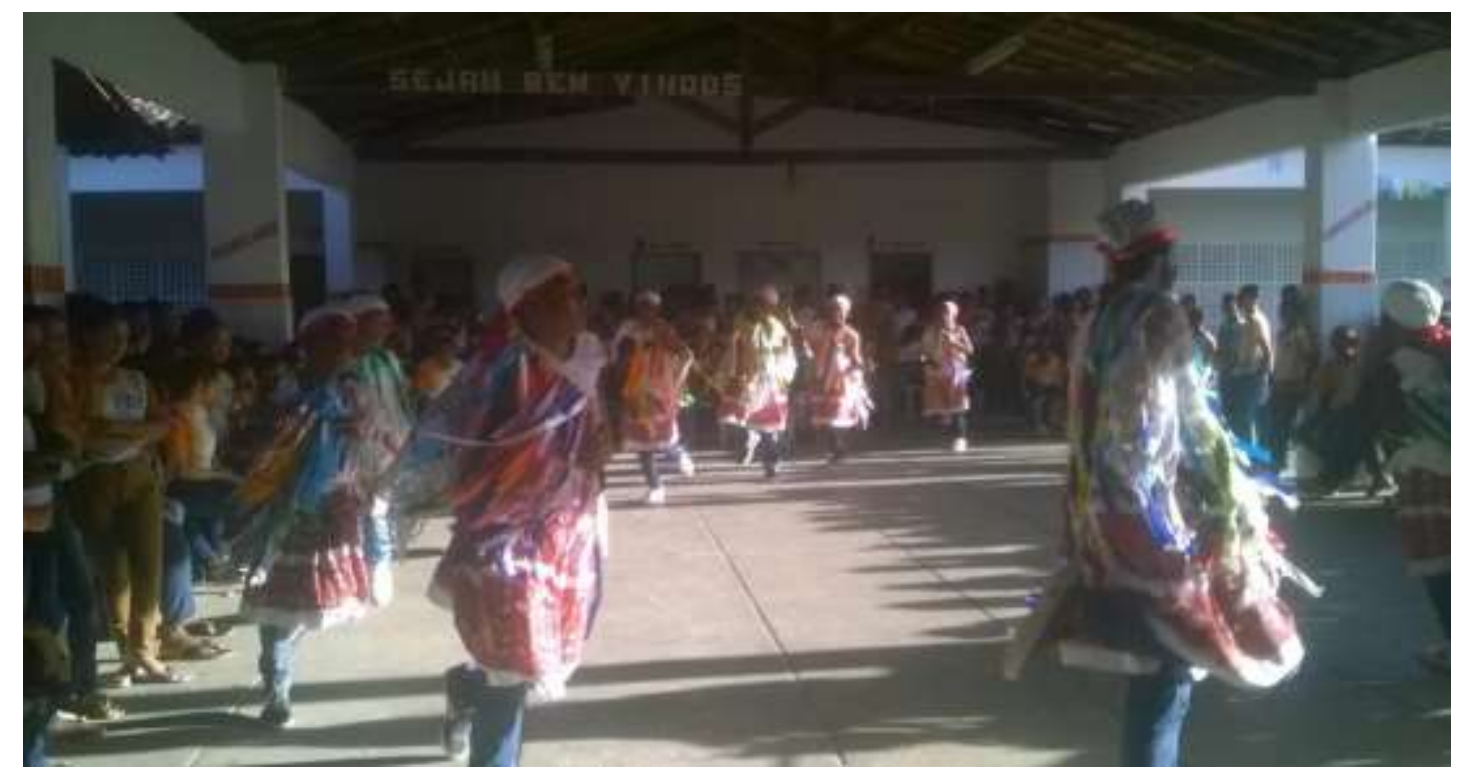

Dança de São Gonçalo no Quilombo da Mussuca. Fonte: Valéria Alves, 2017.

O Povoado de Mussuca, ou o quilombo de Mussuca, em Laranjeiras, celebra essa festa rigorosamente todos os anos há mais de um século:

Estima-se que o santo português nasceu em 1187 e morreu em 1259 (Otávio, 2002; Dantas 1976), participou da Ordem dos Dominicanos, e quando da sua morte foi beatificado pelo Papa Júlio III. O Rei de Portugal, D. João, logo de sua canonização, teria se tornado devoto do santo, espalhando o culto ao santo por todo o país principalmente na região norte de Portugal (Volpatto). Alguns jesuítas vieram para o Brasil, como colonizadores, trazendo a crença em São Gonçalo para diferentes partes do país. Em Portugal, a festa em louvor ao santo possui duas datas festivas; 10 de janeiro e em junho (FALCÃO, 2006, p.4).

Contam os moradores mais antigos de Laranjeiras que São Gonçalo era um sacerdote católico farrista. Ele abandou o ofício e se tornou marinheiro. Construiu alguns instrumentos musicais e ficava na beira do cais dos portos portugueses pregando o Evangelho para as profissionais do sexo que ali ficavam. Ele chamava as mulheres para danças e as convertia. 


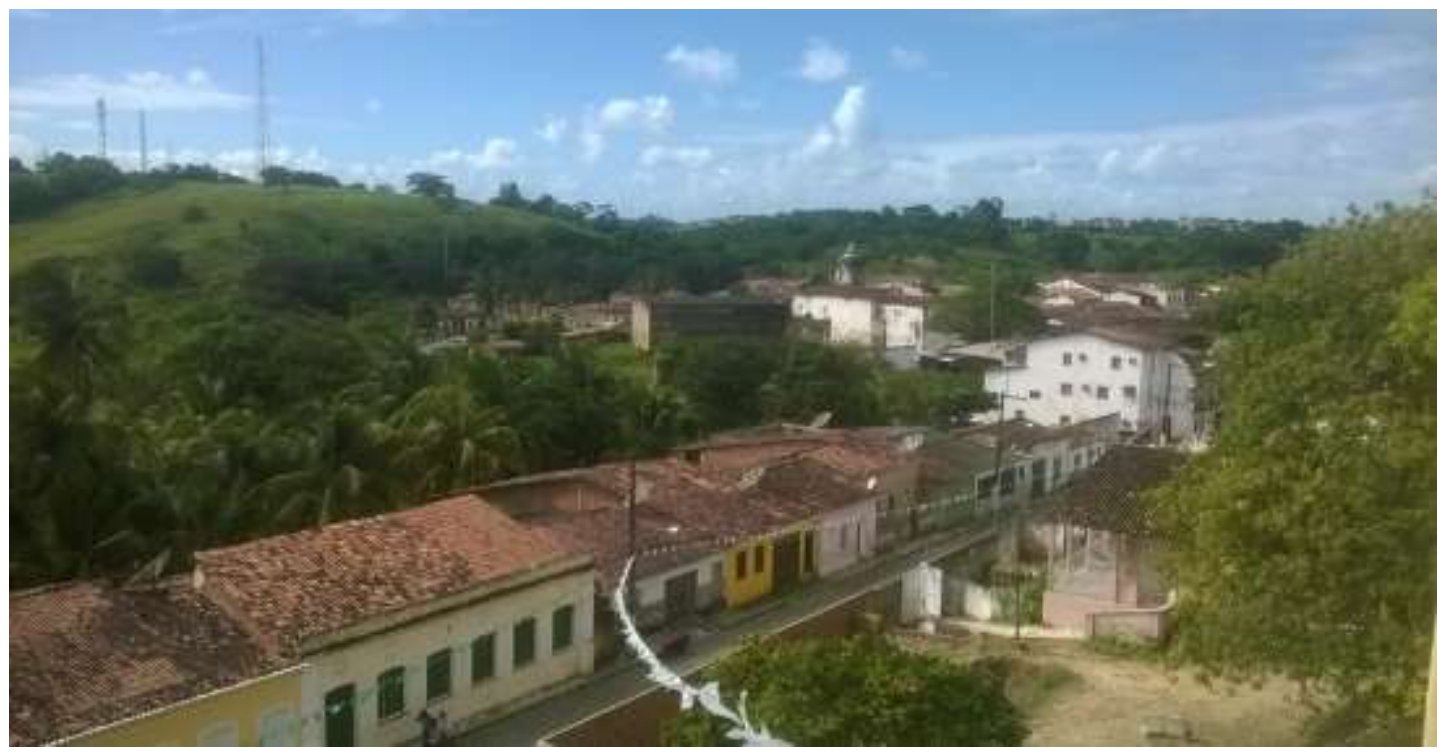

Quilombo da Mussuca. Fonte: Valéria Alves, 2018.

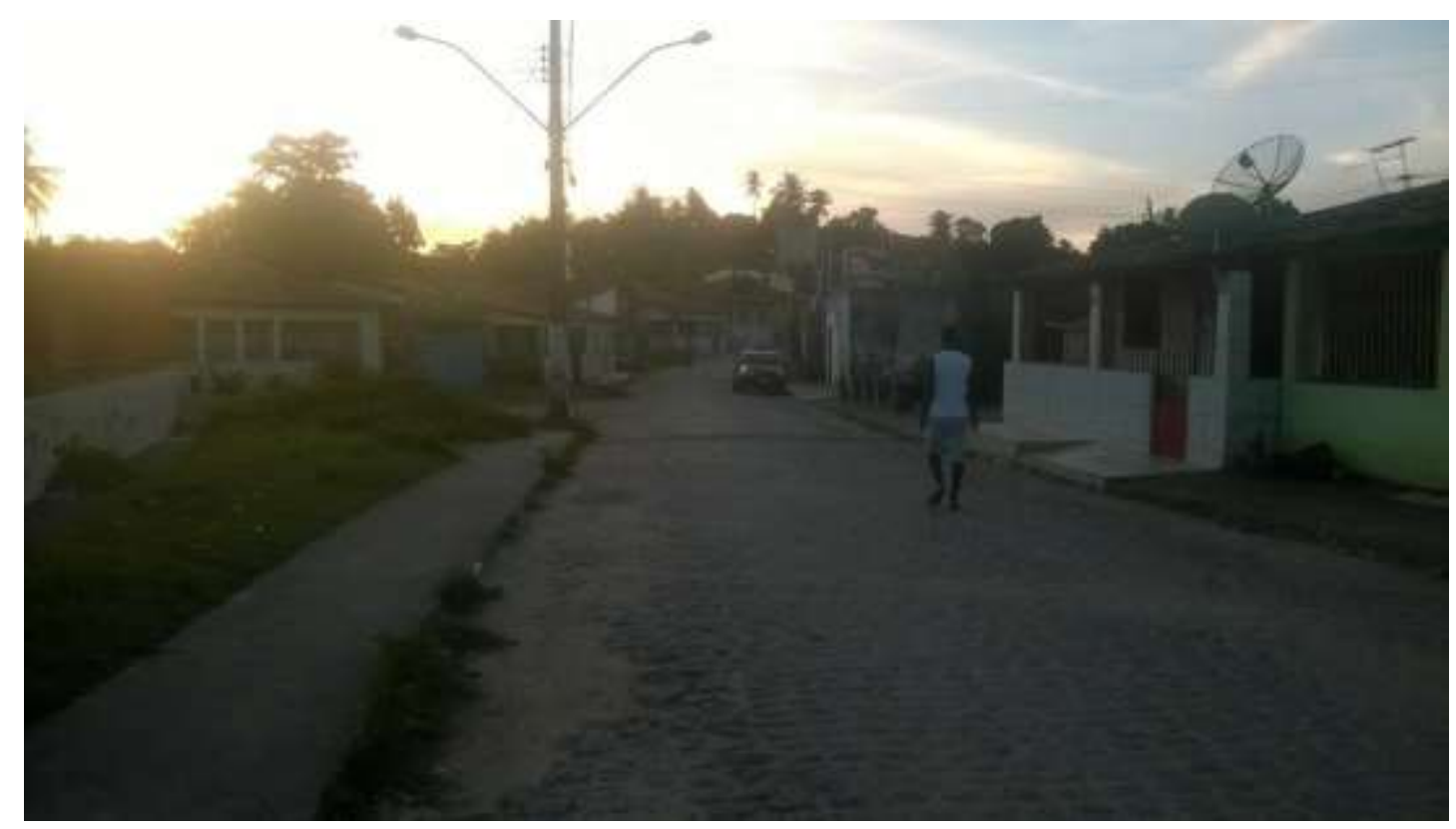

Quilombo da Mussuca. Fonte: Valéria Alves, 2018.

Beatriz Góes Dantas (1988) aponta que, em um dos ensaios organizados por São Gonçalo, uma mulher grávida teria entrado em trabalho de parto e São Gonçalo, ao se deparar com tal situação, teria sido o parteiro. Por isso, o culto ao santo envolve, além da evangelização, os pedidos de casamentos e para ter filhos.

Há duas igrejas em homenagem a São Gonçalo do Amarante em Sergipe, uma construída no povoado de Mussuca e outra em São Cristóvão, antiga capital da província. 
Mussuca mantém a dança de São Gonçalo da sua forma originária: os homens se vestem de mulher, tocam instrumentos musicais como ganzá, caixa, violas. As mulheres não podem participar da dança, apenas uma, a mais velha, que fica encarregada de segurar a imagem do santo.

Essa é uma festa que tem cunho religioso. Quando as pessoas conseguem uma "graça", "milagre" de São Gonçalo, elas vão a Mussuca e participam da festa em agradecimento ao santo (DANTAS, 1988).

Falcão (2006) assinala que esta festa foi elaborada inicialmente pelos jesuítas da região. Eles condenavam veementemente as práticas das culturas negras africanas, por exemplo, o maculelê, a capoeira, o maracatu. Com isso, é possível apontar que a introdução da Dança de São Gonçalo inicialmente teve o propósito de reprimir as práticas culturais negras.

\section{Quilombo da Mussuca}

Aqui, ao final dessas trilhas, abro um espaço para contar sobre o Quilombo da Mussuca. Nas minhas entrevistas com as gestoras escolares, a Comunidade/Quilombo da Mussuca aparece nas falas de maneira contraditória, ora assumindo uma positividade em relação às manifestações culturais e a seus habitantes, ora de maneira pejorativa assumindo um discurso do senso comum e, arrisco dizer, um discurso racializado. Vejamos alguns trechos do meu caderno de campo:

Na fala das gestoras, existe uma valorização da cultura e da história negra do município, porém, existe uma recusa, um afastamento, e uma não percepção dos contextos raciais e de racismo nas escolas e no município. Elas tratam o quilombo da Mussuca como “comunidade” (sugerindo ser uma favela), dizem que de lá saem os melhores alunos, porém falam que "o povo de lá "é preguiçoso", "querem ficar vivendo às custas do governo", "se fazem de coitados porque são quilombolas", "são violentos”, "mas são os mais inteligentes e bonitos da região”. Na entrevista com a Secretária de Relações Raciais e Pesca, que se autodeclarou como afro-indígena - e o tempo todo, durante sua fala, se reafirmava como tal-, apesar da sua crítica, talvez a única mais contundente sobre projetos e parcerias de empresas privadas no município, seu relato sobre a Mussuca, foi: "um povo preguiçoso que não quer evoluir, quer ficar se fazendo de 
coitados por conta da escravidão do passado e querem ficar recebendo dinheiro do governo federal”.

Setenta por cento dos moradores da Mussuca são pescadores, que vivem da pesca de mariscos e peixes. Parte do rio que corta a cidade está assoreado por conta da poluição da Petrobras e da fábrica de cimentos residentes no território. Por conta de uma legislação federal, as pescadoreas e os pescadores recebem cestas básicas e um salário mínimo quando a maré não está boa para peixe.

Confesso que a fala da secretária me chocou! Eu estive na Mussuca algumas vezes, o que existe lá é uma pobreza sistemática. A prefeitura de Laranjeiras retirou o transporte público da região, mesmo sob protestos das moradoras, que agora não têm mais acesso à cidade, a não ser de taxi (quando aparece um) ou de carro particular. Tudo que as moradoras e os moradores da Mussuca precisam fazer (compras, hospitais, Ensino Médio), são obrigados a ir para a cidade mais próxima, para a capital, Aracaju. Eles pouco frequentam Laranjeiras e sentem que a cidade não os quer, embora sejam reverenciados pelos movimentos culturais do município e fora dele.

Em 2017 foi a primeira vez que pisei no quilombo do Mussuca. Fiz seis visitas no decorrer do ano e uma em 2018. Tive a oportunidade de conversar com os habitantes e conhecer um pouco mais sobre a organização local, além de conhecer e conversar com algumas moradoras.

A principal escola da Mussuca foi o meu porto. Nela fui acolhida como profissional e depois como pesquisadora. $\mathrm{Nandi}^{3}$, coordenadora pedagógica de uma das escola,foi a minha principal interlocutora e guia na jornada pelo quilombo. Confesso que não me demorei muito por lá, no sentido de me aprofundar nas relações sociais e no cotidiano das moradoras e moradores. Apesar de circular pelo quilombo, como disse, meu porto foi em uma das escolas.

Surpreendentemente, essa é a única escola de Laranjeiras que é dirigida e coordenada por dois homens, sendo um autodeclarado branco e outro autodeclarado afroindígena. Entretanto, é Nandi quem figura como referência para os estudantes.

Nascida e criada na Mussuca, Nandi relata que lá é um lugar bom para viver, apesar das dificuldades. Conta, que seu bisavô foi um dos primeiros moradores do Quilombo e que

\footnotetext{
${ }^{3}$ Nandi, rainha do Clã Zulu e mãe de Shaka Zulu. Em homenagem/feminagem.
} 
é reconhecido com um guerreiro pelas pessoas. Ela, com 40 anos de idade, só de afastou na Mussuca para estudar em Aracaju, fez faculdade de pedagogia e mesmo assim, ia e voltava todos os dias:

"Minha vida é aqui, na Mussuca. Cresci aqui e sei que é um lugar bom de viver...não sou provinciana e sei que temos muitas dificuldades, mas olha, tem alguma coisa aqui, uma força, uma energia que nos prende, no bom sentido, neste lugar... Você já reparou, professora, como as pessoas da Mussuca são bonitas? Além de serem as mais inteligentes da região. Quem sai daqui para estudar e quer ganhar dinheiro, ganha! Somos bons em matemática, física... É só você comparar o IDEB aqui da escola com o das outras de Laranjeiras. Quando as professoras são enviadas para trabalhar aqui na escola, no começo, elas ficam reclamando porque é afastado do centro, mas, depois que elas veem a turma... nossa! Não querem mais ir embora. Todos os alunos que nasceram e se criaram na Mussuca são inteligentes demais”.

Essa forma de ver e pensar a inteligência das estudantes da Mussuca e a beleza das habitantes foi recorrente, durante meu percurso pelo município, junto às gestoras escolares e funcionárias da Secretaria de Educação. Entretanto, a fala da Secretária de que a Mussuca é um lugar perigoso e de pessoas acomodadas pelo processo escravista, também é recorrente. Parece-me que foi criado um imaginário sobre essas pessoas, talvez por não entenderem os processos das políticas públicas para a população quilombola. A dicotomia parecia recorrente: bonitos e inteligentes versus perigosos e acomodados.

Outra questão que me chamou atenção foi a discriminação que as moradoras da Mussuca sofrem por parte das outras moradoras de Laranjeiras e a decisão da Mussuca em não participar, sempre que possível, da vida cotidiana do município. Em um diálogo com Nandi, ela relata:

Nenhum prefeito dá importância para a Mussuca. Eles não querem a gente por lá. Sempre tem piadas sobre nós porque somos bem negros, escuros... eles são pretos, mas muitos têm cabelos lisos, acham que são morenos, indígenas, sei lá... acham que são melhores. Por mim, eu não ia mais para o centro. Aqui a gente tem tudo! Para você ver, professora, o prefeito tirou o transporte daqui. Não temos como ir pro centro, só de carro, então vamos para Aracaju fazer nossas coisas. Eles não vêm aqui e a gente não vai lá, mas foi escolha deles. Sabe quem vem aqui? Você, os estudantes da UFS e os turistas. Agora, quando tem que apresentar o São Gonçalo, tudo quanto é Secretaria do município 
vem chamar a gente. Mandam vans, lanches e tudo mais, parece que nossa existência se resume à nossa cultura, mas só essa cultura.

Tem muita contradição, professora. Não vou falar que é racismo, porque eu não sei se é, mesmo porque quase todo mundo de Laranjeiras é preto ou descendentes de índio e, sabe, são as mulheres que mais sofrem com tudo isso, daqui e da lá. Por isso acho que a gente deveria se juntar, se organizar, sabe? Mas eles acham que ficamos no passado vivendo só a cultura de escravidão e não tem nada a ver. Aqui temos internet, vários grupos de WhatsApp dos moradores, nossos meninos sempre conseguem emprego na fábrica e com cargo bom! Mesmo assim, eles veem a gente como se ainda estivéssemos no passado da escravidão. Nem sei quem começou com essa história, mas é assim desde que sou criança.

Ao olhar para estes processos, é possível indagar sobre a constituição das noções sobre cultura, identidade negra e sobre as relações raciais estabelecidas no Brasil. Isso requer fazer um movimento de retorno a ações sociais e raciais e, ao mesmo tempo, observar as maneiras pelas quais os processos colonizatórios ainda estão presentes na atualidade, com uma nova roupagem, provocando uma ressignificação destes conceitos no plano da teoria, mas, principalmente, incidindo na vida cotidiana. A intelectual Lélia Gonzalez (1984) faz uma análise interessante que nos possibilita avançar nas percepções desses processos.

A luta das mulheres negras na América Latina inicia-se com a travessia forçada pelo Atlântico, a partir do contato com o colonizador é marcado pela violência física, simbólica e moral, ao mesmo tempo que pela resistência e criação de alternativas de sobrevivência pelas mesmas no "Novo Mundo" (GONZALEZ, 1984)

A América Latina, colonizada majoritariamente pela Espanha e Portugal, foi marcada pela construção de relações hierárquicas que privilegiaram o homem, o branco, o europeu e seus descendentes. Esses dois países, antes da colonização do Novo Mundo, tiveram experiências baseadas em guerras raciais, onde ideologias de classificação social, seja sexual ou racial, foram utilizadas para pensar as estruturas hierárquicas de suas sociedades, e que foram importadas para suas colônias nas Américas (GONZALEZ, 1984).

A posição de mulheres negras e indígenas nesse continente foi construída a partir de operadores ideológicos comuns, raça e gênero. Devido a essa posição social, essas foram as pessoas que mais sofreram com a discriminação e as desigualdades. 
A experiência da colonização deixou como desafio para mulheres negras na América Latina, além da luta pelas condições básicas de vida, a necessidade de reconstruírem suas identidades, que foram marcadas pelo estereótipo da inferiorização diante do colonizador branco europeu.

\begin{abstract}
O racismo latino-americano é suficientemente sofisticado para manter negros e indígenas na condição de segmentos subordinados no interior das classes mais exploradas, graças a sua forma ideológica mais eficaz: a ideologia do branqueamento, tão bem analisada por cientistas brasileiros. Transmitida pelos meios de comunicação de massa e pelos sistemas ideológicos tradicionais, ela reproduz e perpetua a crença de que as classificações e os valores da cultura ocidental branca são os únicos verdadeiros e universais. Uma vez estabelecido, o mito da superioridade branca comprova a sua eficácia e os efeitos de desintegração violenta, de fragmentação da identidade étnica por ele produzidos, o desejo de embranquecer (de "limpar o sangue" como se diz no Brasil), é internalizado com a consequente negação da própria raça e da própria cultura (GONZALEZ, 1988).
\end{abstract}

Antes de organizar-se enquanto mulher negra, existe o movimento de reconhecerse enquanto mulher negra e, assim, possibilitar refletir sobre sua condição diante das relações sociais. Esse movimento de reconhecimento é marcado, antes, por uma experiência de violência simbólica, o não reconhecimento do que se é; existe reação diante dessa violência que perpassa pelo reconhecimento da negritude como um movimento político de afirmação da identidade. Segundo Gonzalez, o estereótipo produz sobre a mulher negra um movimento de abolição da "sua humanidade, elas são vistas como corpos animalizados: por um lado são os 'burros de carga' (do qual as mulatas brasileiras são um modelo). Desse modo, se constata como a relação socioeconômica se faz aliada a superexploração sexual das mulheres 'amefricanas"”.

O movimento feminista da América Latina, até os anos 80, teve grande dificuldade de trabalhar as especificidades das mulheres ameríndias e amefricanas (GONZALEZ, 1988) no interior de seu debate político. Pois tinha como base o feminismo europeu, movimento que compreendia a categoria mulher como homogênea e universal. A inserção das mulheres negras e indígenas no movimento feminista dessa região foi um desafio enfrentado por esses segmentos para fazer valer a sua pauta entre as mulheres brancas. Muitas vezes eram acusadas de racistas às avessas, sectárias e antifeministas, as mulheres que se articulavam dentro do movimento de mulheres e apontavam para suas especificidades levando em consideração sua identidade racial. 
(...) nossas experiências com o Movimento de Mulheres, caracterizavam-se como bastante contraditórias: em nossas participações em seus encontros ou congressos, muitas vezes éramos consideradas "agressivas" ou "não-feministas" porque sempre insistimos que o racismo e suas práticas devem ser levados em conta nas lutas feministas, exatamente porque, como o sexismo, constituem formas estruturais de opressão e exploração em sociedades como a nossa. Quando, por exemplo, denunciávamos a opressão da exploração das empregadas domésticas por suas patroas, causávamos grande malestar; afinal, dizíamos, a exploração do trabalho doméstico assalariado, permitiu a "liberação" de muitas mulheres para se engajarem nas lutas "da mulher". Se denunciávamos a violência policial contra os homens negros, ouvíamos como resposta que violência era aquela da repressão contra os heróis da luta contra a ditadura (como se a repressão, tanto num quanto noutro caso, não fizesse parte da estrutura do mesmo estado policial-militar) (GONZALEZ, 1982).

As mulheres negras não ficaram inertes diante das formas de opressão social e desconhecimento de sua pauta política, como vítimas do homem branco, negro ou da mulher branca. Como se segue, a história nos mostra que elas se tornaram sujeitos de agência social, também manipularam essas categorias que foram construídas a partir de seus corpos a seu favor. Construíram, assim, uma imagem positiva de ser mulher e negra, além de manipulá-las defendendo a implementação de políticas específicas que levassem em conta suas particularidades. Elas não são, diante dessas categorias de diferenciação, "coisa", mas sim "ser", e estabeleceram diante delas ações que visavam a transformação social.

Foucault (1977) aponta que poder não significa somente a sujeição de um determinado grupo, e nem sujeição como forma de regra ou dominação de um grupo sobre o outro, estas são, segundo ele, "suas formas terminais". O poder vem de todas as partes e as lutas e enfrentamentos transformam o mesmo, através de relações dinâmicas que desestabilizam os modos de dominação. As relações de poder não são estáticas, não existindo, segundo o autor, dualidade opressor/oprimido. Os discursos são produtores de relações de poder, o discurso cria a imagem da mulher como "inferior", da negra como "exótica". Porém, não há discurso do excluído e do dominante, há uma multiplicidade de discursos, e as mulheres negras, diante da imagem criada sobre si e que as colocam em situação desfavoráveis, criam diversos discursos, se movimentam e lutam, nesse caso, pelo reconhecimento de seus direitos e de suas especificidades.

A dificuldade de se integrar ao movimento feminista fez com que esses grupos de mulheres violentadas racialmente tivessem sua militância organizada primeiro em outros movimentos. No caso do Brasil, a luta das mulheres negras começava dentro de casa, o 
que as levava para o movimento de moradia e movimento negro. A partir de suas experiências no movimento negro, essas mulheres ajudam a desmantelar categorias que se articulam para promover a exclusão:

(...) o Movimento Negro (MN) - e falemos do caso brasileiro ao explicitar a articulação entre as categorias de raça, classe, sexo e poder, desmascara as estruturas de dominação de uma sociedade e de um estado que vêem como natural o fato de que quatro quintos da força de trabalho negra sejam mantidas aprisionadas em uma espécie de cinturão socioeconômico que lhes "oferece a oportunidade" de trabalho manual e não qualificado (GONZALEZ, 1982).

A participação das mulheres negras no movimento negro junta uma nova categoria para se pensarem as formas de exclusão na sociedade: o gênero. E, diferente do movimento de mulheres, onde a categoria raça foi desconsiderada, a categoria gênero passa a ser vista como mais um dos operantes que se soma às estruturas de exclusão da sociedade brasileira. Vale lembrar que, mesmo assim, as mulheres negras sofriam com o machismo dos homens negros dentro do próprio movimento. Se no movimento feminista suas questões eram desconsideradas, no movimento negro eram consideradas, mas talvez não compreendidas nas práticas dos homens negros, que oprimiam essas mulheres.

A organização das mulheres negras se dava com mais facilidade dentro do movimento negro do que dentro do movimento de mulheres porque segundo Lélia Gonzalez:

Cabe aqui um dado importante da nossa realidade histórica: para nós, amefricanas do Brasil e de outros países da região - assim como para as ameríndias - a conscientização da opressão ocorre, antes de qualquer coisa, pelo racial. Exploração de classe e discriminação racial constituem os elementos básicos da luta comum de homens e mulheres pertencentes a uma etnia subordinada. A experiência histórica da escravização negra, por exemplo, foi terrível e sofridamente vivida por homens e mulheres, fossem crianças, adultos ou velhos. E foi dentro da comunidade escravizada que se desenvolveram formas políticoculturais de resistência que hoje nos permitem continuar uma luta plurissecular de liberação. A mesma reflexão é válida para as comunidades indígenas. Por isso, nossa presença nos ME (movimentos étnicos) é bastante visível; aí nós amefricanas e ameríndias temos participação ativa e em muitos casos somos protagonistas. Mas é exatamente essa participação que nos leva a consciência da discriminação sexual. Nossos companheiros de movimentos reproduzem as práticas sexistas do patriarcado dominante e tratam de excluir-nos dos espaços de decisão do movimento. E é justamente por essa razão que buscamos o MM, a teoria e a prática feministas, acreditando aí encontrar uma solidariedade tão importante como a racial: a irmandade. Mas o que efetivamente encontramos são as práticas de exclusão e dominação racista que tratamos na primeira 
sessão deste trabalho. Somos invisíveis nas três vertentes do MM; inclusive naquela em que a nossa presença é maior, somos descoloridas ou desracializadas, e colocadas na categoria popular (os poucos textos que incluem a dimensão racial só confirmam a regra geral) (GONZALEZ, 1988). 


\subsection{Laranjeira: "uma prisão a céu aberto"? O que ouvir e como contar}

Encerro estes percursos iniciais por Laranjeiras, seus caminhos, trilhas e arredores, com uma história paradigmática para minha percepção etnográfica. Retomo mais um trecho de caderno de campo:

Era sexta-feira, meu último dia em campo. Comentei com algumas gestoras que me acompanhavam durante o almoço que eu aproveitaria o período da tarde para ir aos mercados públicos de Aracaju a fim de comprar badulaques para a minha casa. Uma jovem professora que acabara de assumir o cargo de coordenadora pedagógica de uma escola em um bairro próximo à área central da cidade, ofereceu-se para ir comigo. A princípio pensei que esse oferecimento se tratava apenas de uma gentileza. Agradeci prontamente e disse que não era preciso. Para o meu espanto, ela insistiu e disse que estava com a tarde livre e queria "respirar outros ares". Disse-me, ainda, que conhecia as melhores lojas do mercado, aquelas "que vendem as coisas mais bonitas e mais baratas". Aceitei o oferecimento da sua companhia, pois, desde que a conheci, nossas conversas tinham sido, de maneira geral, agradáveis, e temas como alimentação saudável, qualidade de vida e ascendência familiar eram os nossos favoritos.

Logo, Nininho, o motorista que me acompanhava no trajeto diário de Aracaju para Laranjeiras e vice-versa, nos pegou e partimos, para o mercado central. No início do percurso, eu ainda estava um tanto tímida na companhia dessa jovem, que chamarei de Inhambita ${ }^{4}$ fiz a seguinte pergunta:

Valéria - Como é viver em Laranjeiras?

Inhambita - É bom, mas é ruim.

Valéria - Não entendi. Explica pra mim.

Inhambita - É bom porque praticamente todo mundo se conhece a gente se ajuda. É como uma grande família, a cidade é bonita, cheia de histórias bonitas. Laranjeiras, no tempo dos escravos, foi quem construiu todo o Sergipe.

Valéria - E o que tem de ruim?

\footnotetext{
${ }^{4}$ Esse nome é em homenagem à uma tia avó que tinha esse apelido, por conta da semelhança física das duas.
} 
Inhambita -Ah, professora! Laranjeiras é uma prisão a céu aberto, a gente tá presa aqui, não tem muita saída. Você pode estudar, formar, trabalhar, mas mesmo quem tem dinheiro fica preso aqui.

Valéria - Me conta como é isso?

Inhambita - Conto sim! Se prepara... risos.

Neste momento, Inhambita ajeita-se no banco do carro, afrouxa o cinto de segurança, vira-se para mim e, num tom de fofoca, começa a narrar fatos do cotidiano dos habitantes do município. Eu peço permissão a ela para gravar a nossa conversa em meu celular, explico que é para a minha pesquisa de doutorado e que nada tem a ver com o trabalho. Ela, um tanto receosa, aceita, mas pede para não mostrar a ninguém. A jovem gestora faz um percurso narrativo que contempla desde pequenos episódios que foram marcantes em sua vida a fatos que envolvem a política, a economia, o desemprego, a corrupção $e$ outras múltiplas violências às quais os e as moradoras de Laranjeiras são submetidos frequentemente.

Valéria -E por que você acha que é uma prisão a céu aberto?

Inhambita - Vou te contar. Vou te dar um exemplo... Aqui em Laranjeiras temos três famílias que dominam tudo. Desde que eu me entendo por gente, são eles que mandam e desmandam. Tudo tem que pedir permissão pra eles, mas depende de quem tá no poder no momento, de quem tá lá na prefeitura. Nenhum deles mora aqui, os antigos da família moravam, mas eles não, mas... Vou te falar... Tudo passa pela mão deles.

Valéria - Sério, e o que é que passa pelas mãos deles?

Inhambita - Tudo, tudo. Por exemplo... As escolas dos povoados ficam dentro das fazendas deles. Você sabe né, aqui o que dá dinheiro ainda é a plantação de cana de açúcar. Então, para ter reunião de pais nessas escolas, a gestão tem que combinar a data com os gerentes das fazendas e dizer o que vai ser tratado. As escolas não têm autonomia e nenhum Secretário de Educação até hoje tomou alguma providência. Eles não têm força. São tudo indicados. A gente não tem a quem recorrer.

Nininho - Ah! Isso é normal. Laranjeiras sempre foi assim.

Inhambita - E tem mais, professora... Se a família, o pai do aluno reclamar ou for contestar alguma coisa, é mandado embora do trabalho, tem que tirar o filho da escola, e fica malvisto. O pior é que ele não tem pra onde correr. Vai falar com quem? Com o prefeito? Com o promotor? Dinheiro para ir embora, também não tem.

Valéria - Mas a gente sabe que não pode tirar uma criança da escola e deixá-la sem estudar, não é? 
Inhambita - Sim, mas a criança não fica sem escola. A família vai atrás de um dos grupos rivais e pede ajuda. Consegue escola, às vezes consegue trabalho, mas depois tem que trabalhar de graça nas eleições. Votar neles. Aqui é coronelismo e não tem jeito.

Valéria - E o que a população fala sobre isso? O pessoal protesta? Tem algum movimento?

Inhambita - Só os sindicatos, mas esses daí, também tão tudo vendidos... Estou falando professora, Laranjeiras é uma prisão a céu aberto! Vivemos ainda como no tempo de nossas avós, parece que estamos no século XIX, ainda. O tempo passa e não passa ao mesmo tempo.

Esse breve diálogo é apenas um fragmento de uma conversa extensa sobre fatos que ocorrem no cotidiano das e dos laranjeirenses. Inhambita apresentou-me uma face do município, embora essa já fosse eminente e, de certa forma, por meio da minha convivência no município, apreendida por mim há algum tempo.

Justamente por isso, a narrativa de Inhambita não me causou espanto. No entanto, as angústias dela ao relatar esse e outros acontecimentos, e o receio da nossa conversa ser exposta para as gentes do município, fez-me refletir, naquele momento, sobre quais narrativas seriam possíveis e acessíveis para compor a tese. A pesquisa certamente trará demandas e desafios de variadas dimensões.

Buscando entender o porquê grandes mobilizações sociais promovidas por sindicatos e outras organizações não coincidiam com o voto político em candidatos indicados por eles, Palmeira (2002) deparou-se, entre populações camponesas do Nordeste brasileiro, com uma concepção de política que associa política a eleições. O período eleitoral era referido como o tempo da política, a época da política ou, simplesmente, a política.

A referência constante que as pessoas faziam ao período eleitoral quando respondiam a suas perguntas sobre a política do município ou do estado, levou Palmeira (2002) a pensar, inicialmente, de que se tratava de um regionalismo para referir-se a algo meramente circunstancial.

Contudo, a descoberta desse mesmo tipo de associação no Rio Grande do Sul (Palmeira e Heredia 1995, apud Palmeira 2002), bem como suas idas a campo em período de eleições e fora do calendário eleitoral, fizeram Palmeira (2002) afastar tanto a ideia de que se tratava de uma maneira de falar regional das pessoas em Pernambuco, quanto da suposição da circunstancialidade. 
Logo, o tempo da política não é a tradução perfeita para eleições, embora as englobe. O tempo da política envolve candidatos e eleitores, mas também toda a população. No tempo da política, o cotidiano dessas populações é subjugado, o conflito é autorizado, as facções políticas são explicitadas plenamente e as divisões da sociedade são exibidas. No tempo da política, "período marcado por rituais e interdições", "mais do que a escolha de representantes e governantes, parece estar em jogo um rearranjo de posições sociais" (Palmeira, 2002, p 1-2).

Em artigos anteriores, embora tenha explorado as diferentes definições de tempo dessas populações, Palmeira (2002) reconhece que, na expressão tempo da política, suas explorações se aprofundaram apenas nas acepções do termo política. Não por acaso, a palavra política e tempo da política são empregados como sinônimos.

Palmeira (2002), contudo, nota que a palavra tempo, combinada com outros termos, é usada com a mesma equivalência por essas populações ao se referir ao "tempo de festas, tempo de safra, tempo do plantio, tempo da Quaresma, tempo da greve substituíveis por festas, safra, plantio, Quaresma, greve -, mas também tempo de Arraes, tempo do sindicato, tempo das greves, quando as coisas não são intercambiáveis", indicando para o leitor que, em tais usos,

parece estar em jogo menos uma concepção qualquer de tempo como o representamos habitualmente, linear ou cíclico, cumulativo ou nãocumulativo, e mais uma certa maneira de a população recortar/representar a estrutura social. Trata-se menos de estabelecer um desenho qualquer de temporalidade e mais de descrever ou de postular um conjunto de atividades adequadas e um ritmo próprio à sua consecução em um determinado momento (Palmeira 2002, p. 2).

$\mathrm{O}$ autor aponta incompatibilidades tópicas entre os diferentes tempos, devido a algumas discrepâncias entre as finalidades de cada tempo. Por exemplo, a incompatibilidade entre o tempo da política e o tempo de festas. O tempo de festas é adequado para a congregação e o tempo da política é apropriado para a explicitação de conflitos e divisões. Comportamentos adequados a determinadas finalidades exigidas por certo momento podem ser incompatíveis com as finalidades exigidas por outro momento 5 .

Então, a ordem social é percebida em termos comportamentos adequados para finalidades de cada momento (tempo) e não em termos orgânicos ou mecânicos como foi

\footnotetext{
${ }^{5}$ Esta oposição entre os tempos, todavia, não é absoluta. Maria Isaura Pereira de Queiroz (1969, apud Palmeira, 2002), por exemplo, demonstra que se trata de uma oposição relativa, pois, nas vilas do Brasil colônia, as eleições eram realizadas preferencialmente no tempo das festas natalinas.
} 
naturalizado no senso comum intelectual. O tempo de greve, na visão do patrão, é um período de "subversão". Na visão dos camponeses da zona canavieira de Pernambuco "é de Lei parar de trabalhar" no tempo de greve.

Por sua vez, todos esses tempos, cada um ao seu modo, são incompatíveis em relação ao curso do tempo cotidiano. Haveria um certo tipo de relação de oposição eternidade-tempo. O curso do tempo cotidiano assume o lugar de eternidade, de permanência, oposto ao tempo, que ocupa a posição do transitório, do contingente. Transitório, mas, paradoxalmente, excepcional, pois este tempo foi criado para o desempenho de atividades importantes para a sociedade.

Como lembra a teologia política medieval de Kantorowicz (1957, apud Palmeira, 2002), este tempo "perecível” é criação divina; foi criado junto com o mundo transitório, desde a primeira hora até o último dia. Esta excepcionalidade dos tempos também é indicada por Otávio Velho (1995, apud Palmeira, 2002), que menciona a tradição que considera que "o tempo é de Deus e não dos homens", cuja concepção enfatiza o caráter sagrado de certos dias (dias santos e domingos) em oposição aos dias de trabalho (cotidiano), a qual os camponeses recorriam para exigir autonomia na utilização do tempo (a ser usufruído para si).

Palmeira (2002, p. 4), sugere que há indícios dessa mesma lógica de excepcionalidade operando no tempo da política e em outros tempos, "marcados por rituais e relações de evitação", aos quais se refere. Após descrever uma representação gráfica desenhada na areia por um poeta popular nordestino e de analisar um poema que este poeta analfabeto recita para Shepard Forman (1979), que o transcreve sobre o local apontado no desenho pelo poeta, Palmeira (2002) chama atenção para a contraposição, no poema, entre "saber e fé" e "estudo e ciência", indicando que "saber e fé" são pensados como uma "ordem divina" e "estudo e ciência" como uma "ordem humana".

Esse pensamento recorrente na região poderia ser lido como um sintoma da "importância crucial" do tempo assim concebido para os camponeses brasileiros. A referência de Forman (1979, apud Palmeira, 2002) à "suspensão do tempo" pelos movimentos messiânicos na sua "condenação do presente" e busca por uma "sociedade mais justa e perfeita", é interpretada por Palmeira (2002) como "o confronto entre comportamentos e tempo". O tempo cotidiano, para aquela coletividade, deveria ser posto em suspensão "para que pudesse ser reordenado ou recriado", conforme os critérios de “criação do mundo e do tempo na versão bíblica" (Palmeira 2002, p. 174).

Esta “concepção agostiniana de sociedade política" (Palmeira 2002, p.174), que, 
segundo Quentin Skinner (1978: 50, apud Palmeira 2002, p. 174), seria "uma ordem divinamente decretada e imposta aos homens decaídos como um remédio para seus pecados", é vista por Palmeira (2002, p. 174) como "uma espécie de 'teologia política' contemporânea na concepção de poder político dos camponeses". Como descreve Afrânio Garcia Jr (1983, p. 93-94, apud Palmeira 2002, p. 174), na “Terra”, o poder está encarnado em três personagens que regulam o comportamento social: “o Presidente, o Governo e o Papa", concebidos como pessoas de força, dotadas de atributos (divinos?) e não como ocupantes de cargos elegíveis periodicamente, isto é, "um mandatário seu”.

Nesta sociedade dividida em tempos (não em esferas e espaços), a princípio tudo é “temporalizável”, mas somente é "temporalizado" (tempo da política, por exemplo) “o que é considerado socialmente relevante pela coletividade em um determinado momento. Nela, o rol de tempos não é fixo nem permanentes suas incompatibilidades" (Palmeira, 2002, p. 175).

Há algumas regularidades sociais na vida camponesa que as pessoas se referem metaforicamente como sendo tempo. A feira é referida por um informante ao justificar porque mulheres não vão a feira como um "ambiente", um "clima de tempo" adequado para homens e inapropriado para mulheres, como a missa o é para elas. Mesmo circunscritas espacialmente, a feira e a missa mexem com a coletividade. Mas estas "situações sociais" não têm a capacidade do tempo da política, por exemplo, de transformar, de "contaminar" e de "dominar" todo tecido social: "Converter as demais atividades [socialmente reconhecidas] na atividade definidora do tempo, é uma das características diferenciais dos tempos no sentido restrito" (Palmeira, 2002, p. 175).

Do ponto de vista político, tal concepção dificulta a "“acumulação' para os que estão "embaixo"”. Pois a visão não-orgânica da estrutura social (tempos "estanques") representa obstáculo maior aos que não têm ou têm pouca força em certos momentos (tempo da greve) para transpor sua força para outros tempos (tempo da política). Entre dois tempos da política, os perdedores não acumulam experiência e tendem a se aliar aos vencedores, os que têm força, os de cima. Já estes (homens de força, homens do tempo, homens da política), estendem suas redes pessoais e "acumulam" homens.

Essa configuração das relações envolvendo a política local incidindo nos modos de vida. ocasionando uma sensação de aprisionamento relatada por Inhambita, esteve presente em outros momentos, em outras conversas com minhas interlocutoras. Tempos e temporalidades percorrem as falas e estão no cotidiano dessas habitantes de Laranjeiras. 
No decorrer deste trabalho os aprisionamentos retornam com novas roupagens. Veremos que o tempo presente está com um pé, ou dois, no passado. 


\title{
Capítulo 2. Mediando Conveniências, Pautando Inconsistências: raça, cultura e educação na gestão escolar em Laranjeiras
}

\begin{abstract}
No nosso tempo, as professoras eram respeitadas, a diretora da escola era mais importante que o prefeito. Ai da gente se falássemos alguma coisa sobre elas, minha mãe me colocava no castigo. Hoje em dia... hum... ninguém respeita as diretoras, quanto mais as professoras. As famílias só vêm para a escola para exigir e criticar, a escola virou um depósito de estudantes e todo mundo quer se meter na educação, todo mundo tem um projeto que dizem ser inovador, que vai melhorar os índices e tudo mais. Mas na verdade, hoje em dia, eles só querem formar bois pro trabalho pesado.

- Maria Pera, gestora
\end{abstract}

Este capítulo comporta dois objetivos, são eles: apresentar a gestão escolar de Laranjeiras que, a partir das suas perspectivas, tensões e ambiguidades, conduziram algumas análises deste trabalho, dando luz aos objetivos principais desta tese, quais sejam: perscrutar as implicações das parcerias público-privadas na educação, tendo como campo etnográfico o município de Laranjeiras. Ademais, apresentar o recente cenário e discussões sobre gestão escolar no Brasil.

Neste capítulo, continuo percorrendo minhas experiências em Laranjeiras sob a condução das gestoras escolares, diretoras e coordenadoras pedagógicas do município. Para tanto, apresento um olhar etnográfico a partir do meu acompanhamento das atividades educacionais do município, uma vez que, como dito anteriormente, tenho um interesse especial por essa temática. Nesse percurso, apresento, além de conversas, entrevistas formais com as gestoras, que marcam o momento em que meu acompanhamento nas atividades se transformou na minha pesquisa de doutorado. Reafirmo que minha inserção em Laranjeiras se deu por um convite para acompanhar as escolas e a Secretaria de Educação na implementação de um projeto elaborado por uma parceria público-privada a uma instituição vinculada a um grande grupo empresarial.

A gestão escolar e as novas perspectivas educacionais estão em análise neste capítulo, que igualmente apresenta alguns enquadramentos acerca de políticas públicas e da organização do Estado brasileiro - questões que referenciam também o que é apresentado no Capítulo 3. Discutimos, por exemplo, as transformações ocorridas em algumas políticas educacionais no que tange, principalmente, a gestão das escolas. Além disso, trago as experiências de estudo e trabalho de gestoras lotadas na Secretaria de 
Educação do município, atentando para como o território se organiza em termos educacionais e para as relações de poder, gênero, classe e raça.

Maio de 2017, no município de Laranjeiras, Sergipe, era início da manhã e o calor já se anunciava forte. Deparei-me com um grupo de trinta e quatro gestoras escolares. Refiro-me a gestoras, no feminino, porque dessas pessoas que compõem e direcionam o ensino, trinta delas são mulheres. Ao me verem percebi em seus rostos um tímido sorriso, apresentando um misto de alegria, satisfação, reconhecimento, espanto, medo, protesto e dúvidas, muitas dúvidas.

Após um breve buchicho entre elas, uma se achegou a mim e disse: "bem-vinda, professora! Nós nunca imaginávamos que quem viria acompanhar nosso trabalho era uma moça assim, como você. Nós não sabemos direito como esse projeto funciona e o que temos que fazer, mas, mesmo assim, seja bem-vinda". Eu sorri e respondi: "sou eu mesma, muito prazer, vamos aprender juntas".

Naquele instante eu não questionei a fala da gestora, mesmo porque eu não havia entendido nitidamente o que ela (e todas elas e eles) estavam ponderando. Os olhares agudos e curiosos e os comentários em tom de voz baixa me produziram a seguinte percepção, que foi certificada ao longo do meu convívio com elas: as relações de raça, gênero, região e geração são compostas de especificidades que só quem as vivencia em determinados momentos tem a exata percepção das suas dimensões.

Percebo que existem nessas relações dois pontos ou direções que nos comportam dentro de uma sociedade fraturada pelo racismo, sexismo, uma variedade de preconceitos e pelas desigualdades sociais. O primeiro ponto ou direção diz respeito a uma afetividade que liga pessoas que, mesmo vivendo em diferentes contextos, sentem na própria "pele" cotidianamente o peso desagradável de experienciar uma sociedade com um passado escravocrata marcada pela subjugação de um grupo complexo que compõe mais da metade da população. O segundo ponto diz respeito à resistência, ou não, de se deparar com o que podemos chamar de "racismo da surpresa", ou seja, "uma moça assim como eu", como disse a gestora: mulher, negra, sudestina, autoafirmada e reafirmada, estudada e com reconhecimento e permissão para acompanhar atividades complexas, como as que aconteceriam ali. Causa surpresa porque, numa sociedade como esta citada acima, o 
comum e "normal" é ver e ter pessoas opostas a este perfil organizando e planejando tais tarefas.

A antropóloga Heloísa Buarque de Almeida (2002), ao refletir sobre o percurso das mulheres em campo, aponta que existe, em alguma medida, uma situação conflituosa sobre o lugar e sobre o comportamento esperado, o qual uma mulher deve ter nos variados registros culturais que percorremos realizando pesquisas de campo. Ela indica que, logo de saída, espera-se que a pesquisadora antropóloga adeque-se às convenções de gênero locais. Dialogando com a análise da autora, acrescento que era evidente em meu campo, articulada à performatividade de gênero, dinâmicas relacionais de afirmação racial.

A atividade que menciono é uma ação direcionada para a educação, com foco na gestão educacional e escolar de Laranjeiras, arquitetada, organizada e ministrada por uma instituição privada que tem ligações diretas com o município. Com um formato de consultoria/formação, a ação recebeu o nome de parceria na qual agentes públicos lotados na Secretaria de Educação do município se encarregam de operá-la e operar a si a partir das propostas conjecturadas pela instituição privada.

Acima retratei o meu primeiro encontro com o grupo que compunha a gestão escolar do município. Apresentei as feições e suas falas ao me conhecerem e compreendo que se faz necessário refletir e discorrer sobre elas. A alegria, satisfação e reconhecimento remetem a um lugar de pertencimento que, a meu ver, está diretamente ligado à ascendência racial que nos é comum. Diz respeito a um conforto por saber que as trocas e as atividades possivelmente seriam mais fáceis de acontecer com alguém que, vista como semelhante, provavelmente entenderia as posturas, aflições e contendas que essas novas atividades sinuosamente trariam. Sobre o espanto, já elucubramos acima. O medo, protestos e dúvidas têm a ver com os direcionamentos que essas novas atividades, apontadas, segundas elas, de maneira imperativa e sem uma consulta prévia, provocariam. Essas elucubrações foram confirmadas nas entrevistas e conversas que tivemos no momento, posterior, quando regressei ao município para realizar trabalho de campo.

Ao longo de um ano, frequentei a vida dessas mulheres gestoras e elas a minha. Meu contato com os homens gestores ficou circunscrito às atividades do trabalho que fui realizar. Com elas, a relação foi diferente. Não demorou muito para me acionarem e permitirem que eu conhecesse as suas rotinas, tanto no trabalho, como na vida cotidiana e as relações que elas estabeleciam na cidade. Relações de proximidades e afastamentos, de críticas e revoltas, de afinidades e afetos. A relação que elas me proporcionaram vivenciar não comportou a vida íntima, familiar, e sim, a vida social citadina. 
Nossas conversas giravam em torno das condições do trabalho, sobre como viver em um município que elas consideravam esquecido pelo poder público e que era, por vezes, rejeitado por elas. Giravam também em torno das influências internas e externas das políticas educacionais e sobre os desafios e enfrentamentos que travam em relação às mesmas, incluindo a atividades que fui realizar. Tivemos, também, longos diálogos sobre o tempo. Tempo clima: o calor sufocante e a escassa chuva. Tempo do município: no qual as paisagens, as pessoas e as políticas são de outro tempo que não o presente. Tempo do trabalho: a educação do passado e do presente.

Em relação ao projeto que fui acompanhar, "nada" em seu formato institucional propiciava tal aproximação. As discussões sobre as temáticas citadas, entretanto, emergiam nos intervalos, nas finalizações de cada atividade, nos períodos noturnos. Esses eram nossos enredos. Uma teia de conversação não prevista nos meus planos e que foi acontecendo.

Foi pelo olhar dessas mulheres gestoras que conheci Laranjeiras e as problemáticas que a cercam, o modo de vida das e dos moradores e frequentadores, ou seja, funcionários dos órgãos públicos moradores da capital e estudantes da universidade federal. Os sistemas políticos, alguns códigos e contendas e as diferentes nuances e contradições do trabalho exercido por elas.

Quem eram essas gestoras escolares? Eram professoras concursadas na rede municipal de ensino e que, em 2017, assumiram a gestão das escolas como diretoras e coordenadoras pedagógicas. Muitas entraram na docência somente com o magistério e depois de alguns anos, por exigência da carreira, cursaram Ensino Superior. Elas tinham muito a dizer sobre a vida cotidiana das escolas e se empenhavam verdadeiramente nas suas atividades, porém havia algumas limitações por conta de exigências práticas e teóricas que o cargo exige, requisitos que elas não haviam tido acesso até aquele momento.

Esses desafios eram de diversas naturezas, das mais simples às mais sofisticadas. Entretanto, cito os atributos concernentes à gestão escolar que mais me chamaram a atenção e que era preciso, à época, que elas já tivessem desenvolvido. Por exemplo, ter noções básicas de informática: manipular os processadores de texto, organizar tabelas simples, elaborar um Power Point, saber acessar e-mails. Conhecer algumas diretrizes básicas da educação: o Plano Municipal de Educação do Município, as discussões sobre a Nova Base Comum Curricular, as orientações previstas em lei para promover uma gestão escolar democrática. Podemos considerar esses como requisitos mínimos para se 
começar a efetivar uma gestão considerada adequada no que tange ao sistema educacional brasileiro. As habilidades que aqui nomeio de sofisticadas são: manusear ferramentas digitais como plataformas de Ambientes Virtuais de Aprendizagem (AVA), participar de encontros, conferências e congressos sobre educação.

Assim como em muitos municípios do Brasil, a equipe gestora das escolas é composta por indicação política. Em 2017, os municípios tiveram os postos de executivo e legislativo renovados, ou não. O certo é que, com a entrada de novas e novos prefeitos e vereadoras, a gestão dos órgãos públicos passam por mudanças. De modo geral, quem assume cargos de gestão nas secretarias são profissionais indicados pelo executivo com a influência direta ou não, do legislativo.

Não foi diferente em Laranjeiras. Essa troca propiciou que as professoras assumissem a gestão escolar das escolas. Friso que essa é uma prática comum no Brasil. São poucos os municípios em que a gestão é concedida por meio de concurso público. Mas o que é gestão escolar? Quais as funções que ela abarca? Em que momento diretoras de escolas e coordenadoras pedagógicas passaram a ser chamadas de gestoras escolares? Quais são as discussões referentes a esse campo de atuação? Vejamos.

A temática da gestão escolar começou a ser debatida mais densamente com o surgimento do Curso de Especialização em Gestão Escolar em 2007 na Universidade Federal de Rondônia a partir de um acordo com o Fundo Nacional da Educação Básica (FNDE). Este curso visou a formação continuada de dirigentes da educação básica pública, com o objetivo de formar especialistas em gestão escolar na perspectiva da gestão democrática e efetivação da melhoria da qualidade da educação, focalizando as resoluções de problemas cotidianos do ambiente escolar (COLARES et al., 2009). A construção do projeto político pedagógico, a importância da participação das famílias e da comunidade na escola, a necessidade da construção de uma equipe colaborativa, as sinuosidades e problemáticas que abarcam a diversidade de gênero, étnico-racial, de sexualidade e as questões que envolvem autonomia escolar e gestão democrática foram os principais pontos.

Paro (2012) enuncia que, a partir dos anos 1990, o modelo de gestão da educação passou a ter uma razão mercantil. A educação passou a ser enquadrada como algo singular para se alcançar o sucesso, sendo necessário dar a ela um tratamento cuidadoso. O autor argumenta que há aí uma contradição: a razão mercantil nega a educação.

As nossas escolas, e/ou sistema educacional, estão atrasadas, fora do tempo em termos de metodologia. Ainda se procura formar pessoas que "passem de ano" e que 
tenham boas performances nas avaliações externas. Todas baseiam-se no conceito tradicional de educação, ou seja, um estudante atrás do outro, olhando a professora. Segundo o autor, existe um amadorismo pedagógico quando se repetem na escola os mesmos critérios de uma empresa.

O termo gestão escolar vem justamente desses arranjos. Mas como é concebida a gestão escolar no Brasil? Primeiramente, é importante ressaltar aqui o que e quem forma a gestão de uma escola. Neste sentido, dois papeis ou profissionais são destacados: a diretora, vista como tendo um papel mais administrativo, e a coordenadora pedagógica.

De forma geral e ideal, a diretora de uma escola exerce funções administrativas, sem perder de vista as atribuições pedagógicas, o que geralmente não acontece em muitos municípios, incluindo Laranjeiras. A diretora também exerce uma função intermediária entre a Secretaria de Educação e as autoridades ligadas ao sistema educacional, como a inspetoria de ensino do Estado. Libâneo aponta que:

As escolas estão vinculadas a um sistema de normas e diretrizes regidas pelas autoridades do Estado, as quais tem incumbência de indicar objetivos mais amplos de qualidade de ensino a ser atingida, fornecer os meios concretos para alcança-los, acompanhar a aplicação de normas ou ações e efetuar as avaliações das escolas (LIBÂNEO, OLIVEIRA e TOSCHI, 2012, p.128).

Apesar dessa subordinação ao sistema de educação, a tarefa de uma diretora é, também, adequar essas regras ao contexto escolar, ou seja, à sua localidade de trabalho. Nesse processo, é função da direção dialogar constantemente com a comunidade escolar: conselho de escola, associação de pais e mestres, as associações civis, sindicatos e partidos políticos. Espera-se dessas profissionais uma atitude democrática junto à comunidade. Esse seria um sistema ideal, porém, foi possível observar algumas incongruências entre o que se espera e o que é realizado. Vejamos alguns depoimentos das gestoras de Laranjeiras:

Eu tento fazer uma gestão democrática. Tento mesmo! Mas aqui no município não tem condições, não tem! As famílias não participam de nada, só das festas, exigem, exigem e nada. Só vem pra escola quando são chamados para tratar dos filhos. O conselho escolar aqui é supernovo, tomara que dê certo. Nós não somos ouvidas, tudo é goela abaixo, vem lá de cima sem consulta, sem nada, e a gente tem que obedecer (Adelina). 
Quando era só professora, reclamava da desorganização das diretoras das escolas que trabalhei, agora que sou diretora, vejo que fui muito injusta. A direção da escola está praticamente sozinha. Tem muitas coisas que não sabemos fazer e temos que fazer. Tinha que ter um curso, um curso prático. Tem muita burocracia nas nossas mãos. Um monte de lei, é difícil (Anastácia).

Estudiosos em gestão escolar preveem que é de suma importância que as diretoras das escolas estejam abertas e aptas a inovações e que desenvolvam uma capacidade plena de liderança, que envolva as famílias, as professoras e os estudantes. No entanto, pelos relatos acima e pela atividade que acompanhei junto às diretoras, a realidade não condiz com as orientações destinadas a essa função.

A diretora de escola, de forma geral, ocupa a maior parte do seu tempo aprendendo e resolvendo questões burocráticas, documentos, papeis, prestações de conta e outras questões estruturais, como garantir a merenda, o papel higiênico nos banheiros, a quantidade de livros didáticos que chegam e que sobram, as diversas manutenções do prédio. E para tudo isso é necessário um aprendizado que só acontece na prática, no cotidiano. Assim, o tempo para fazer essa integração com a comunidade escolar interna e externa é escasso, mas isso não quer dizer que é impossível ou que não é feito, pelo menos parcialmente.

A coordenação pedagógica, também tem suas especificidades. Ela responde pelo desempenho das atividades didático-pedagógicas. Faz uma articulação e ministra formação junto às professoras das escolas. Constrói com elas as concepções e formas de aprendizagem das estudantes. Esse é seu principal papel. Além disso, faz o acompanhamento das aprendizagens, a elaboração de estratégias didáticas, diagnósticos, instrumentos e insumos que favorecem as inclinações didáticas daquele contexto:

De acordo com os estudos recentes sobre formação continuada de professores, o papel do coordenador pedagógico é o de monitoração sistemática da prática pedagógica docente, sobretudo mediante procedimentos de reflexão e investigação...cabe-lhes, entre outras, a atribuição de coordenação das reuniões pedagógicas e entrevistas com os professores, para promover relação horizontal e vertical entre as disciplinas, estimular projetos conjuntos com os professores, diagnosticar problemas com ensino-aprendizagem, adotando medidas preventivas, e adequar conteúdos, metodologias e práticas avaliatórias (LIBÂNEO, OLIVEIRA \& TOSCHI, 2012, p. 502-503). 
Segundo a e os autores, foi difundida a ideia de que a função de diretora e de coordenadora são modos bem diferenciados da mesma função, porém, defendem a ideia de que cada um tem suas especificidades e precisam de formação específica para exercerem seus cargos. No entanto, ressaltam que o trabalho nas unidades escolares precisa ser exercido em sintonia. A parceria e o trabalho entre a diretora e a coordenadora forma o que chamamos de gestão escolar.

A escolha da direção escolar é tema de alguns debates por especialistas em educação. Fala-se muito na escolha da direção e pouco da coordenação, mas é possível inferir que as formas de escolha podem ser válidas para as duas atividades.

Vitor Henrique Paro (2007) apresenta três modalidades de escolha de gestoras escolares, são elas: nomeação, concurso público e eleição. A escolha por nomeação, que geralmente acontece por critério político partidário, é considerada uma alternativa ruim em virtude do clientelismo político e pela falta de base técnica da gestão. Esse critério não visa o interesse público, mas sim o privado, tanto da parte das gestoras, quanto da secretária de educação e/ou outros políticos. É considerada uma escolha autoritária e sem a participação da população. Essa é uma alternativa vista como antidemocrática.

A segunda modalidade é o concurso público por meio de provas. $\mathrm{O}$ argumento utilizado para esta modalidade é o pretenso conhecimento das pessoas que prestam os concursos e pretensa imparcialidade. Segundo o autor, a diretora é uma líder política e, por vezes, as pessoas que assumem o concurso de direção não tem ligação nenhuma com a realidade local. O que a gestão precisa é da adesão de todas da escola e essa adesão precisa ser política. Concurso é um critério técnico, mas tem suas limitações, por isso é preciso de competência política e legitimidade para administrar. Isso somente pode acontecer com a manifestação livre dos que são dirigidos.

A terceira modalidade é a eleição, considerada a melhor forma de escolha, uma decisão democrática apoiada pela comunidade escolar. Entretanto, isso não significa que a escola se tornará democrática, há ainda outras relações internas que precisam ser democráticas também.

Neste meandro, o autor aponta outras questões: além da nomeação ser ruim para a escola e para a democracia, o concurso também é, embora não pareça. De forma geral, o concurso veste uma capa da imparcialidade, com seu caráter impessoal.

A Meta 19 do Plano Nacional de Educação, que trata sobre Gestão Democrática, propõe um processo de nomeação híbrida que conjugue desempenho, mérito, 
competência técnica para desempenhar a função e, principalmente, que a comunidade seja consultada.

Em 2011 uma pesquisa realizada pela Fundação Vitor Civita apurou que 67\% das Secretaria Estaduais do país utilizam da eleição direta para o cargo e $42 \%$ usam a indicação (Revista Nova Escola, 2012).

No livro Administração Escolar: introdução crítica, Paro (2012) apresenta uma outra forma de nomear a gestão escolar, ele usa o conceito de administração como sinônimo de mediação. Para ele, gestão significa mediação para alcançar um fim, enquanto administração é a preocupação com todos os recursos, inclusive o humano, e é preciso ter coerência entre os meios e os fins, sendo a escolha da diretora apenas um detalhe. Esse autor explica que administração supõe o esforço de muitas pessoas e tem que ser feita de modo coordenado, uma espécie de coordenação do esforço humano coletivo. Paro expõe que o que queremos produzir na escola é um ser humano histórico, formar personalidades, e a escola precisa propiciar condições para os sujeitos aprenderem, o ensino tem que ser intrinsicamente desejável e bem feito.

Em Laranjeiras, a escolha das gestoras, das diretoras e coordenadoras se deu por nomeação. É preciso salientar que a gestão escolar muda a cada eleição municipal. Trocam-se o prefeito, os vereadores, os secretários e as gestoras das escolas.

As gestoras de Laranjeiras haviam tomado posse do cargo em 2017, quando da entrada do novo prefeito eleito. Eu as conheci no primeiro ano de gestão. Algumas já haviam sido diretoras e coordenadoras antes dessa nova gestão. Muitas trabalharam ativamente na campanha eleitoral e garantiram seu ingresso ou manutenção em seus cargos. Havia, e creio que ainda há, um conflito entre as gestoras escolares e algumas professoras que, destituídas do cargo, voltaram para a sala de aula. Além disso, ser de um partido oposto não lhes oferecia nenhum benefício no que se trata da carreira profissional. Tais questões políticas e os respectivos conflitos serão tratados no próximo capítulo.

Pela ótica das gestoras, voltar para a sala de aula freia a ascensão profissional. Elas também já haviam passado por isso, e tinham um risco iminente de passar de novo. Apesar dessas circunstâncias e do futuro incerto no cargo, as gestoras entrevistadas concordavam que a indicação política era uma forma justa de estar no cargo, afinal, argumentavam:

Maria Aranha - Temos experiência e conhecemos bem cada escola e os estudantes. Temos ligação com a comunidade e somos respeitadas. Já pensou se vem uma 
coordenadora que não sabe nada sobre educação ou de Aracaju por concurso público? Não ia dar certo. Acho que se fizermos um bom trabalho, ficaremos no cargo, mesmo se o prefeito não se reeleger nas próximas eleições.

Valéria -E se tivesse eleição? Se a comunidade pudesse escolher quem será a diretora e a coordenadora da escola? Não seria mais democrático e garantiria a permanência no cargo?

Maria Aranha - Não ia dar certo! As famílias não sabem o que acontece com os seus filhos, que dirá vir escolher quem vai administrar a escola. Foi-se o tempo... essa história de comunidade escolar só existe na teoria.

Não deixo de dar razão a Maria Aranha. Pela minha experiência profissional, eu nunca vi um município que tivesse a escolha das gestoras escolares por meio de eleição direta, muito menos utilizando o método conjugado que propõe Paro (2007), ou seja, nomeação, concurso e eleição. Maria Aranha continua:

Tem que ter competência, tem que ficar bem com as professoras, fazer o trabalho direito. Isso a gente aprende na prática, ninguém fala para nós o que temos que desenvolver, nem a faculdade fala, fazemos isso sozinhas, no dia a dia. Criamos e recriamos. Acho que essa é a maior das competências. Na teoria tudo é bonito, mas da prática, só a gente entende. Aqui é outro tempo, professora, outra história.

Não desconfio da fala de Maria Aranha e, mais uma vez, os tempos vividos e os enunciados se fizeram presentes. No acompanhamento que realizei do projeto de intervenção via parceria público-privada, um dos principais objetivos ali delineados era o desenvolvimento das competências profissionais estabelecidas para esta classe. Esperava-se que elas fossem apreendidas e colocadas em práticas. O curioso e intrigante era que essa ideia de competência profissional não era uma exigência, até aquele momento, do poder público e tampouco do Ministério da Educação. Elas faziam parte da celeuma formativa das instituições privadas que mantêm parcerias e projetos na educação pública.

Ainda é abstrata e confusa a discussão sobre competências profissionais na educação. As gestoras escolares e educacionais passaram por um processo de mapeamento das suas competências profissionais promovido pela instituição que firmou parceria com a município. 
As competências profissionais mobilizadas versavam sobre as capacidades das gestoras em mobilizar conhecimentos e recursos variados com o objetivo de enfrentar diferentes situações de forma criativa e inovadora no ambiente de trabalho. Esses recursos não eram vistos como talentos e sim apreendidos e desenvolvidas na ação, com estudo, por meio de uma prática reflexiva, também com pesquisa, empenho e interesse. A premissa apresentada pela parceria ressaltava que desenvolver ininterruptamente as competências profissionais estabelece um desafio que precisaria ser assumido e integrado ao cotidiano profissional, pelas escolas e pelas redes de ensino de todo o país, sendo essa uma condição fundamental para garantir a qualidade do ensino.

As competências elaboradas por especialistas que, por meio destas, buscavam desenvolver os profissionais e garantir a aprendizagem com qualidade eram: processos de gestão; registro e documentação; acompanhamento das aprendizagens; constituição de equipe colaborativa; parcerias e mobilização social; articulação entre ações da escola e políticas da rede; formação continuada e gestão de recursos. Segundo Costa,

Uma abordagem por competência enaltece o que o discente aprende por si, o aprender a aprender, a construção pessoal do saber através da interação. Enaltece o conhecimento enquanto instrumento de aquisição de competências, elogia os conteúdos enquanto meios possibilitadores de desenvolvimento de competências. Valoriza o método pedagógico e a aprendizagem, superando a dicotomia teórico-prática e enraizando os valores educativos da escola do século XXI (COSTA, 2004, p. 101).

Dias (2010) aponta que o termo competência surgiu pela primeira vez na França no século XV. À época o seu significado basicamente era de aptidão de uma pessoa para resolver problemas. Na primeira metade do século XX, a psicologia adota o termo e o interpreta como uma capacidade de entender, falar e compreender uma língua. Já nos anos 70, o termo competência foi associado à qualificação profissional e entra totalmente numa perspectiva empresarial.

Na educação, o termo se estabelece como uma alternativa à palavra capacidade, aptidão ou habilidade. Ele passa a ser uma construção que visa o desempenho individual. Uma capacidade de mobilizar conhecimentos e atitudes adequadas para resolver questões do cotidiano profissional (DIAS, 2010, p.74).

Nota-se que a educação e todo seu sistema está cada vez mais incorporando processos e termos do segmento empresarial. As gestoras de Laranjeiras, por ocasião da formação continuada a qual frequentavam naquele momento, pela primeira vez, segundo elas, ouviram falar sobre essas competências direcionadas para as profissionais da 
educação. Tivemos dois tipos de reação. (1) No caso de muitas dessas competências que foram apresentadas, ou das práticas que as compunham, e que elas precisariam aprimorar, as gestoras já as desenvolviam no cotidiano do trabalho. Não eram nada novo, a única novidade foi nomear as práticas do cotidiano como "competências profissionais".

Alguns pontos importantes que aquelas competências previam para o desenvolvimento das profissionais eram motivo de constrangimentos, pois elas não haviam conseguido, ainda, condições objetivas para as desenvolverem. O uso das tecnologias de informação e comunicação, chamadas de TICs, foi a principal delas.

A correria aqui na escola é grande, tem muitas coisas que acontecem ao mesmo tempo, tudo eu tenho que resolver, é mãe, é avó, passo dia resolvendo problemas e nem chego perto do computador, e por quê? Não preciso dele para resolver essas questões. As professoras também não, temos uma prática de escrever, mandar informes nos cadernos dos alunos e quando é uma coisa mais burocrática, a Simone faz, ela é a nossa secretária, é jovem e tem prática (Maria Aranha).

O uso, ou o não uso da tecnologia que podemos dizer que é básica, era o maior constrangimento. Alguns fatores são responsáveis por essa situação, por exemplo, boa parte das gestoras é de uma geração anterior à expansão das tecnologias digitais e durante sua vida profissional isso não havia sido uma demanda. Ter computadores em casa ou mesmo nas escolas era muito recente e, geralmente, quem o utilizava era a funcionária da secretaria das escolas. Existe uma ideia construída de que "mexer" com essas tecnologias é muito difícil, causando um afastamento do processo de aprendizagem. Sobre esse ponto, eu presenciei a Secretaria de Educação do município oferecer cursos básicos e rápidos de informática por duas vezes e, das 35 gestoras, apenas 7 se inscreveram. Outros pontos importantes são a precariedade do sinal da internet nas escolas e nas casas e, por último, o uso de celulares e das redes sociais.

Maria Aranha é uma coordenadora pedagógica de uma escola de Ensino Fundamental I. Durante as formações promovidas pela parceria, nossa aproximação teve como principal motivo as atividades que ela precisava entregar, ou melhor, postar na plataforma digital do curso. Ela me acionava frequentemente, dizia não ter vergonha de falar que não sabia "mexer" e de pedir ajuda. Lembro-me que todas as vezes que precisávamos acessar seu e-mail, ela ligava para a filha porque havia esquecido a senha. E isso não acontecia somente com ela. No final do processo, deparei-me com uma página 
do meu caderno de anotações repleto de e-mails e senhas das gestoras. O sistema digital que elas usavam com frequência era o das redes sociais e a senha já estava ali, gravada. Utilizar e-mail não era uma prática comum, inclusive o e-mail do trabalho. Cada escola tinha seu endereço de e-mail e, no geral, quem o acessava eram as secretárias das unidades.

Para mim, havia algo que não se encaixava, pois elas haviam feito uma especialização, em parte via Educação a Distância (EaD), pelo ambiente virtual de aprendizagem. Já no momento do trabalho de campo, preguntei a Maria Aranha:

Valéria - Como você conseguiu fazer o curso à distância se você tem esse afastamento com computadores e com os sistemas digitais? Como que você usava a plataforma do curso?

Maria Aranha - Eu fazia no papel e minha filha digitava e postava para mim.

Valéria - Você não acha importante saber manusear essas tecnologias, afinal, sua profissão exige isso?

Maria Aranha - Exige nada! Esses projetos que falam que a gente tem que saber isso ou aquilo de informática, eles não sabem sobre nosso trabalho e das nossas condições, não temos tempo, professora, para ficar na frente do computador. E, outra, não temos tempo nem pra sentar e, se a gente senta, sempre tem alguém que vai falar: "olha lá, a escola pegando fogo e a coordenadora sentada”.

Trago esse diálogo com Maria Aranha como um exemplo de falas recorrentes sobre o uso das tecnologias digitais na educação básica: uma competência que, segundo os projetos das iniciativas privadas para a educação, seria primordial.

Nas pesquisas e artigos que abordam o uso das TICs na educação, Rezende (2008), Leite (2018) e Silva (2018) focam suas análises nas estudantes e professoras. Por um lado, esses artigos mostram que é necessário cada vez mais o uso das tecnologias nas escolas e que é providencial que se proporcione o uso adequado entre as alunas, que a escola possa conhecer e aplicar essas tecnologias em prol da qualidade do ensino. Enunciam que é preciso que a escola tenha domínio sobre elas e se atualize de acordo com os avanços que essas tecnologias trazem. Os impedimentos encontrados para que isso acontecesse de forma correta são centrados nas professoras, pois são apontadas como resistentes a esse processo ou desconhecedoras dele. 
Essa dificuldade está relacionada principalmente com os professores, que não estavam preparados para usufruir dessas novas tecnologias e não se adaptaram as novas modalidades de ensino. Muitos educadores não se desenvolvem, justamente por não saberem usar de forma adequada esses recursos tecnológicos. (...) a rapidez das inovações tecnológicas nem sempre correspondem à capacitação dos professores para a sua utilização e aplicação, o que muitas vezes, resulta no uso inadequado ou na falta de criação diante dos recursos tecnológicos disponíveis (...) (SILVA, 2018, p. 50).

Todas essas questões têm ligações diretas com as parcerias público-privadas que o município de Laranjeira adotou. Em uma conversa informal com o secretário de educação do município, perguntei qual era o propósito de firmar parcerias com uma instituição privada. Ele respondeu que nem a secretaria e nem a prefeitura teriam recursos financeiros para fazer qualquer tipo de formação, e aquela que fora oferecida não traria nenhum tipo de gasto, não precisaria de recursos públicos. Ressaltou que confiava nos propósitos daquela parceria, pois o grupo empresarial que sustentava a instituição que proporcionou a parceria atuava no território há muito tempo.

Não temos uma produção extensa sobre as PPP e, na educação, este tema ainda é incipiente. Entretanto, quando falamos em políticas públicas e parcerias, as reflexões já construídas em torno da temática podem nos ajudar a entender o funcionamento dessa engrenagem.

Ana Elisa Périco e Daisy Aparecida do Nascimento Rebelatto (2005) apontam que, no princípio dos anos 1990, inicia-se no Brasil uma abertura comercial, a qual exigiu grandes transformações das empresas brasileiras para que estas se adequassem às exigências do mercado mundial. Para assegurar a permanência de indústrias brasileiras neste amplo mercado, fez-se fundamental a sustentação econômica, a qual envolve preciso controle de gastos e investimentos em infraestrutura, visando uma participação mais produtiva e competitiva das empresas brasileiras. Para que uma empresa brasileira elevasse seu potencial de competição e produção seria fundamental o investimento em infraestrutura. Contudo, tal investimento tem sido comprometido, uma vez que é crescente o controle dos gastos públicos.

Tal cenário de limitações por parte do Estado propiciou espaço para a participação da iniciativa privada. Surgiram, assim, inúmeras parcerias de contrato entre os agentes privados e a administração pública. Périco e Rebelatto (2005) apresentam a parceria público-privada como sendo a parceria mais recente, quando escrito seu artigo "Desafios das parcerias público-privadas (PPPs)", o qual apresenta o real potencial desse arranjo no financiamento de obras e serviços públicos no Brasil. 
As autoras indicam que, nos últimos anos, têm-se pautado a importância de uma administração pública equivalente com as necessidades da sociedade contemporânea estando aí presentes duas ideais opostas. Uma defende um Estado forte, burocrático e centralizador; a outra defende a descentralização do Estado e o mercado livre, sendo que a prevalência de uma ou de outra ocorre de forma alternada. Um modelo entra em vigor quando o outro entra em crise.

A fim de estabilizar o papel do Estado frente à globalização, fez-se necessária a elaboração de um modelo de administração pública que atendesse às novas necessidades do mercado. No Brasil, assim como em outros países, algumas reformas no aparato estatal propiciaram a implementação de uma nova gestão pública.

A reforma administrativa foi estruturante para a reforma do Estado. As reformas administrativas visaram estabelecer a separação entre formulação e implementação de políticas públicas, a maior qualidade de performance, a aproximação da gestão pública às estratégias de mercado e a descentralização dos controles gerenciais.

De acordo com Kamarck (2000, apud PÉRICO \& REBELATTO, 2005), uma pesquisa realizada com 123 países que passaram por reformas administrativas indica que a privatização e a descentralização foram as estratégias mais utilizadas pelos países envolvidos:

Em $60 \%$ dos casos as reformas envolveram transferência de funções tradicionais do Estado para os mercados, e em $40 \%$ das reformas se verificou a descentralização de funções e poderes dos governos centrais para níveis locais ou para instituições do terceiro setor (PÉRICO \& REBELATTO, 2005, p. 1034).

Para Jucá (2000, apud PÉRICO \& REBELATTO, 2005), a partir de tais reformas, o Estado passa a regular e mobilizar os agentes econômicos e sociais. Sua principal finalidade é viabilizar a integração ao mercado internacional, a integração regional, assim como a gestão estratégica do desenvolvimento. Já para Pina e Torres (2000, apud PÉRICO \& REBELATTO, 2005), os principais elementos da nova gestão pública são: descentralização do setor público, profisssionalização da gestão no setor público e a introdução de competição neste setor.

Apesar dos fatores apresentados não estarem presentes em todas as regiões nas quais ocorreram as reformas, em quase todos os países as ideias da descentralização e externalização já estão sendo praticadas, quando não, estudadas.

Assim, o objetivo da administração pública passa a ser a garantia do predomínio 
do interesse público e que os serviços sejam prestados com qualidade e menor custo.

Nesse cenário parceria público-privada seria uma alternativa à privatização. Esse tipo de arranjo, envolvendo a iniciativa privada com empreendimentos de natureza pública, não é algo recente, sendo suas primeiras práticas ocorridas no final do século XIX. Tal prática intensificou-se a partir de um contexto mundial de crise financeira do setor público. É na Inglaterra, por volta de 1992, que se dá início a esse novo modelo de negócios entre a iniciativa privada e o setor público, a parceria público-privada. Já no Brasil, a PPP é uma categoria em desenvolvimento. É considerada devido à carência de recursos públicos para investimentos em áreas fundamentais para o desenvolvimento do país, como infraestrutura, e ainda, considerando-se resultados anunciados como positivos apresentados por outros países que adotaram essa prática.

Há ainda inúmeras outras justificativas para adoção do uso das PPPs, tais como:

Compartilhamento de riscos com o setor privado, redução do prazo para implantação dos empreendimentos, estímulo à introdução de inovações, modernizações e melhorias por parte do setor privado, possibilidade de realização de um número maior de projetos, a liberação de recursos públicos para outros projetos prioritários sem condições de retorno financeiro e sem capacidade de serem realizados por meio das PPPs e a garantia da qualidade da operação e da manutenção dos serviços concedidos por longo prazo (BORGES, 2003 apud PERICO \& REBELATTO, 2005, p. 1036-1037).

O Programa de Parceria Público-Privada, no Brasil, tem por objetivo gerenciar, desenvolver, nortear e acompanhar o desenvolvimento das ações propostas e da equipe envolvida na implementação das políticas públicas direcionadas ao desenvolvimento do Estado e ao bem-estar coletivo.

De acordo com o projeto de lei que o enquadra, analisado pelas autoras, ${ }^{6}$

considera-se contrato de parceria público-privada o acordo firmado entre a administração pública e entes privados, que estabeleça vínculo jurídico para a implantação ou gestão, no todo ou em parte, de serviços empreendimentos e atividades de interesse público, em que o financiamento e a responsabilidade pelo investimento e pela exploração incumbem ao parceiro privado (PÉRICO \& REBELATTO, 2005, p. 1037).

No artigo "Desafios das parcerias público-privadas (PPPs)", elaborado por Périco e Rebelatto (2005), são inúmeras as definições de parcerias público-privadas apresentadas por diferentes organizações. Assim, as autoras, agregando as diversas definições e

\footnotetext{
${ }^{6}$ Desde então, o PL 2546/2003 transformou-se na Lei No 11.079.
} 
informações coletadas, elaboram uma nova definição, sendo ela:

parcerias público-privadas são contratos entre a administração pública e a iniciativa privada, de longo prazo (entre 15 e 35 anos), que estabelecem vínculos jurídico para implantação ou gestão, no todo ou em parte, de serviços, obras, empreendimentos e atividades de interesse público, em que o financiamento e a responsabilidade pelo investimento cabem ao parceiro privado, e o governo paga como se fosse um contrato de prestação de serviços. Nesse contrato devem ser observados os princípios de eficiência, respeito aos usuários, indelegabilidade de regulação e poder de polícia, responsabilidade fiscal, transparência, repartição de riscos e sustentabilidade econômica do projeto de parceria (PERICO \& REBELATTO, 2005, p. 1038-1039).

Périco e Rebelatto (2005) indicam que, para os meios políticos e científicos, a existência das PPPs tem sido compreendida como positiva, uma vez que existe no Brasil a necessidade de investimentos os quais o Estado não teria recursos para arcar. Entendese que as PPPs apresentam por finalidade a concretização de empreendimentos sociais de modo a poupar as despesas públicas e ainda propiciar algum crescimento sustentável à economia do país.

As autoras identificam alguns pontos de atenção referentes às parcerias públicoprivadas no Brasil. Segundo elas, a forma como foi redigido o projeto de lei permite que decisões importantes referentes ao investimento governamental sejam tomadas por iniciativas privadas. Outro ponto levantado refere-se à ausência de especificações e detalhamentos referentes à definição do projeto de empreendedorismo, o que daria margens para as diversas empresas apresentarem projetos muito diversificados entre si, dificultando a comparação destes projetos para a seleção da empresa mais adequada.

Outro ponto de atenção a ser considerado é a não especificação referente a quem será designado o investimento que não for feito pelo Estado, uma vez que, no projeto de lei, a captação de recursos para o financiamento de PPPs, não é limitado à iniciativa privada. Quando divulgados os contratos de PPPs, anunciados pelo Ministério do Planejamento, notou-se que muitos deles seriam financiados pelo Banco de Desenvolvimento Econômico e Social (BNDES), ou ainda por fundos regionais, ou seja, seriam, de qualquer forma, financiados com dinheiro público. Passa-se a questionar o quanto esse tipo de transação envolvendo dinheiro público e iniciativa privada em obras públicas seria satisfatório, tanto para a sociedade quanto para o Estado.

Uma vez que a Lei de Responsabilidade Fiscal não permite o endividamento do agente público a longo prazo, há o impedimento do financiamento de obras públicas diretamente com agências públicas. Para a iniciativa privada, o projeto de lei que 
determina as PPPs assegura a garantia de pagamento por parte de Estado, pagamento este que poderá ser realizado de inúmeras formas, todas previstas no projeto de lei.

Referente ao êxito das parcerias público-privadas, alguns países indicam que um mercado de capitais maduro e a existência de um mercado secundário sofisticado e complexo seriam os principais fatores para o sucesso das PPPs. Já no Brasil, ambos os instrumentos citados não estão bem desenvolvidos, fazendo com que os estados brasileiros busquem alternativas para o sucesso de suas parcerias.

Em Minas Gerais, por exemplo, que possui uma lei própria, utilizou-se como estratégia a criação paralela de um fundo de incentivo ao programa de PPP. Trata-se de uma nova forma de estratégia que em 2005, ano no qual foi produzido o artigo em questão, só existia no Brasil e tinha como objetivo proporcionar maior garantia ao contrato.

Outra estratégia levantada, visando solucionar a imprecisão referente ao acesso aos recursos, foi a busca por fundos setoriais específicos para cada projeto de PPP. Pensou-se em tais fundos como uma forma de tornar mais brando o risco da PPP em arcar com possíveis despesas não descritas na remuneração do parceiro privado, na elaboração do projeto.

Périco e Rebelatto (2005) mostram que, desde que a negociação da prestação de serviços públicos passou a ser feita a partir de licitações, houve uma queda considerável da inadimplência da administração pública. Ao contrário de inadimplência, houve o aumento da realização dos pagamentos, o que resulta em aumento do déficit fiscal.

Contudo, quando se consideram os riscos do setor público, não haveria, no projeto de lei analisado pelas autoras, qualquer especificação a esse respeito, não sendo oferecidas garantias que assegurassem a predominância do interesse público frente ao interesse privado, nem ao menos, que ambos tivessem as mesmas possibilidades de respaldo.

Quando considerado o modelo público-administrativo para o desenvolvimento de projetos, a Lei da Responsabilidade Fiscal é citada como bastante benéfica, pois acaba por assegurar o equilíbrio dos gastos públicos e também controla o endividamento do Estado a longo prazo estabelecido em contrato.

Uma vez iniciado um contrato de PPP, o investimento inicial é feito pela iniciativa privada. Durante o período no qual a obra é implantada, não há pagamento por parte do Estado, que passará a pagar ao longo do prazo estabelecido em contrato, que pode ocorrer entre 15 e 35 anos. O valor referente ao investimento inicial é diluído em parcelas, as 
quais serão pagas neste período.

A fim de garantir a seleção da proposta mais vantajosa para o Estado, instauraramse as Leis de Licitações e Contratos e de Concessão. Tal lei estabelece normas gerais sobre licitações e contratos administrativos referentes a diversos serviços, tais como: obras, locações, serviços, compras e alienações no campo dos poderes do país, dos estados, dos municípios e do Distrito Federal. "A Lei de Licitações e Contratos, assim como a Lei de Concessões, apresenta princípios de moralidade e ética que, se cumpridos, tornam todo e qualquer contrato entre agente público e iniciativa privada íntegro, assegurando a prevalência do interesse público" (PÉRICO \& REBELATTO, 2005, p. 1043-1044).

Tais leis são reconhecidas por agências privadas e públicas no país, contudo, este reconhecimento não garante que sejam respeitadas, ou que todos os contratos estabelecidos sigam o previsto em lei.

Os processos de licitação são bem estruturados e objetivos. Teoricamente, devem seguir determinados critérios, sendo previamente estabelecidas características financeiras e técnicas a serem adotadas pelos interessados. Estas especificidades deveriam determinar as empresas participantes da disputa, contudo, os contratos estão sujeitos à discricionariedade do administrator público, o que abre brechas para outros critérios que não os previamente estabelecidos, tornando o processo suscetível à corrupção.

Tomando os pontos de atenção apresentados, Périco e Rebelatto (2005) entendem que, no momento em que foi escrito o artigo, o projeto de lei que institui as parcerias público-privadas apresentava pontos fracos que poderiam comprometer o êxito destas parcerias. $^{7}$

Considerando o cenário internacional, notam-se algumas diferenças nas associações entre os setores público e privado. Na Inglaterra, por exemplo, é possível identificar diferenças significativas. Lá, algo equivalente às PPPs é denominado private finance initiative (PFI). Diferentemente do Brasil, que não arca com nenhum valor quando realizado o investimento inicial, na Inglaterra, tal investimento é de responsabilidade das duas partes envolvidas. Outra grande diferença é que apenas $30 \%$ do valor total dos contratos de PFI é de responsabilidade da iniciativa privada.

Ao ser implantado tal modelo de parcerias na Inglaterra, surgiram inúmeros desafios, os quais foram observados e corrigidos de forma árdua. Houve a necessidade da

\footnotetext{
${ }^{7}$ Não é minha intenção neste capítulo desdobrar esse debate de feitio jurídico, apenas assinalar alguns dos contornos institucionais do campo etnográfico que percorri.
} 
regulamentação dos contratos, que passaram a ser auditados por uma instituição independente do governo. Foram realizadas autorias, avaliações e correções, a fim de tornar o contrato mais seguro para as partes envolvidas, refletindo em mais segurança para a sociedade.

A Confederação Nacional de Indústria lista alguns fatores determinantes para o sucesso de uma parceria público-privada, sendo eles: "compromisso político, legislação adequada, expertise, priorização dos projetos e a existência de um fluxo regular e previsível de provisão dos serviços e pagamentos" (PERICO \& REBELATTO, 2005, p. 1046). Para a confederação, uma vez seguidos tais fatores, podem ser descartadas quaisquer características individuais das partes envolvidas, como o contexto socioeconômico, por exemplo, pois os fatores listados seriam realmente determinantes para o êxito das parcerias.

Périco e Rebelatto (2005) citam outros exemplos internacionais de sucesso e insucesso. Percebe-se que não há um modelo único para que tais parcerias sejam realizadas de forma exitosa, contudo, quando considerado o insucesso das parcerias, os fatores são recorrentes: "falhas legais e regulatórias, inadequado processo de seleção das empresas privadas, má avaliação dos custos e investimentos, falta de adequados agentes regulatórios ou de controles das parcerias e menosprezo de possíveis desvantagens e riscos (por exemplo, ambientais e modificações unilaterais pelo concedente)" (PÉRICO \& REBELATTO, 2005, p. 1047).

As autoras concluem destacando que, ao comparar experiências internacionais, deve ser levado em consideração há quanto tempo esse novo modelo de parceria tem sido empregado. A Inglaterra, um dos países pioneiros dessa prática, apresentaria ótimos resultados, enquanto países que iniciaram a prática mais recentemente não possibilitam avaliação, uma vez que os projetos seguem sendo elaborados ou ainda necessitam ser finalizados.

Nota-se que, apesar de a experiência de sucesso em um país não garantir que o mesmo ocorra em outros países, o insucesso ocorre, de um modo geral, quando há falhas regulatórias e na definição de prioridades.

Deve ser ressaltado que as parcerias entre a iniciativa privada e agentes públicos têm por objetivo principal a prevalência do interesse público. No caso do Brasil, tal parceria se faz fundamental, principalmente em obras de infraestrutura. Contudo, os pontos de atenção levantados, como o marco regulatório das PPPs no país, por exemplo, podem dar margem a desvios, comprometendo esse tipo de parceria. 
Périco e Rebelatto (2005) reforçam que os contratos devem ser elaborados de forma cautelosa e fundamentada para que as parcerias público-privadas tenham o sucesso esperado. Outro fator importante refere-se à forma com a qual os contratos são gerenciados. Cabe à gestão pública o gerenciamento dos agentes privados e não o contrário, a fim de garantir a ordem e evitar possíveis desvios.

Por fim, é importante ressaltar que qualquer embaraço que surja desse tipo de contrato, é fundamental para que, a partir dos erros e acertos, possa ser moldado o modelo brasileiro de contrato de parceria entre os setores público e privado, considerando-se o contexto e a legislação brasileira.

A minha intenção aqui não é aprofundar reflexões sobre os usos das tecnologias de comunicação e informação e sobre as competências profissionais que se pressupõem que uma "boa" gestora escolar deva ter, tão pouco avançar neste capítulo com as questões referentes às PPPs. O foco aqui é olhar para essa conjuntura e analisar os encaixes e desencaixes que essas novas perspectivas aguçadas e promovidas por instituições privadas sobre a educação pública, principalmente em Laranjeiras, trazem de benefícios e de constrangimentos e analisar para quem cabe cada um, se para o público ou para o privado. 


\subsection{Mulher, Raça, Classe e Carreira: o que se faz, o que se sonha, o que se tem!}

Eu não queria ser professora, eu queria ser freira, mas meus pais me disseram que não tinha freira preta. Fiz letras quando o polo da UNIT chegou na cidade, mas ensino todas as disciplinas desde jovem. Eu cresci em Laranjeiras, amo minha cidade e espero que ela tenha uma mudança, uma cidade cheia de encantos culturais, apesar da pobreza. - Acotirene

A epígrafe acima foi uma escolha intencional. Acotirene foi a primeira interlocutora que, durante minhas entrevistas formais, queixou-se não de forma negativa ou ressentida sobre seu sonho ou sua intenção de ter outra profissão que não a do magistério. A princípio, pensei que essa questão, de uma forma geral, abarca muitas profissionais de diversas áreas. No entanto, chamaram-me a atenção dois pontos que foram repetidos por outras gestoras: 1 - a escolha da carreira docente foi muito mais por uma "imposição" social, devido às condições objetivas destas e 2- a escolha pela carreira dos seus sonhos foi impedida pela forma que as relações raciais são estruturadas no Brasil, influenciando, quase que automaticamente, o mercado de trabalho.

Eu queria ser aeromoça, mas minha família ria e dizia que não tinha aeromoça preta. Eu tentei, mas minha mãe não concordou, então eu fiz o curso regular e fui dar aula de tudo. Quando a faculdade chegou aqui, eu já era diretora de escola, não tinha opção de curso, então eu fiz letras (Esperança Garcia).

São muitos e diversos fatores que influenciam a desistências de mulheres negras por algumas carreiras. O não acesso a algumas profissões por essas mulheres são promovidas pelo racismo estrutural no mercado de trabalho. Esperança Garcia fala sobre seu desejo interrompido de ser comissária de bordo: não foi sua condição objetiva de classe que a impediu e sim, o sonho foi tolhido pela cor da sua pele. Podemos nos perguntar, por exemplo, quantas mulheres negras vemos trabalhando como comissárias de bordo? Minha experiência com viagens mostra que são bem poucas, pelo menos no Brasil. Procurei dados concretos sobre perfil racial das comissárias no Brasil e não encontrei. No entanto, há uma boa quantidade de reportagens em jornais relatando casos de racismo sofridos por comissárias negras por parte de passageiras e da tripulação. 
É preciso ressaltar que não é apenas esse ofício que deixa as mulheres negras apartadas de ter uma profissão desejada, volto a repetir que o problema é estrutural. $\mathrm{O}$ Retrato das Desigualdades: gênero e raça, de 2011, faz um levantamento estatístico apontando as evidências das desigualdades em vários setores: distribuição da população segundo sexo/gênero; número de famílias chefiadas por mulheres; média de anos de estudo da população ocupada com 16 anos de idade ou mais, segundo sexo e cor/raça; mulheres com 40 anos de idade ou mais, segundo realização de exame clínico de mamas e localização do domicílio; distribuição dos domicílios que recebem Bolsa Família, segundo cor/raça do/da chefe familiar; taxa de desemprego da população de 16 anos de idade ou mais, segundo sexo e cor/raça; proporção de trabalhadoras domésticas com carteira de trabalho assinada, segundo cor/raça; distribuição de domicílios urbanos em favelas, segundo sexo e cor/raça do/da chefe familiar.

Esses dados são importantes para compreendermos a situação da população em relação ao acesso aos principais veículos para a estabilidade social. Destaco aqui alguns que acredito serem importantes para nos ajudar a entender as falas das gestoras interlocutoras de Laranjeiras ao expressarem seus sonhos profissionais iniciais, os quais ainda não puderam realizar.

Em 2009, segundo o Retrato das Desigualdades: gênero e raça (2011), na região nordeste, $20,5 \%$ das pessoas negras estavam em situação de analfabetismo contra $14,2 \%$ de pessoas brancas. A média de estudo da população negra acima de 16 anos teve um aumento de 2,4 anos, no entanto, se compararmos negros e brancos, pessoas negras, em 2009, contavam com uma média de 6,7 anos, enquanto as brancas 8,4 anos, uma diferença ainda notável. Segundo o Retrato das Desigualdades “(...) há um fosso a ser superado que combina, gênero, raça e educação" (Ipea, 2011, p. 21).

Na Educação, o Retrato apresenta que a desigualdade começa na Educação Infantil. Em 2009, tínhamos 20,2\% de crianças brancas de 0 a 3 anos matriculadas em creches públicas contra $16,7 \%$ de crianças negras na mesma idade. Entretanto, é no Ensino Fundamental e Médio que ela se acentua, como, por exemplo, apontado na Distorção Idade-Série, que é um instrumento para medir a proporção de estudantes com atraso escolar de 2 anos:

Tanto no ensino fundamental como no ensino médio, observa-se a maior distorção idade-série entre crianças e jovens negros do sexo masculino. No ensino médio, a taxa de distorção idade-série atinge $41 \%$ dos jovens negros contra $26,9 \%$ dos jovens brancos. 
No entanto, atinge $38,2 \%$ de jovens negros contra $24 \%$ das mulheres brancas (Ipea, 2011, p.22).

No Ensino Superior, em 2009, a taxa de escolarização das mulheres brancas era de $25,8 \%$ e de mulheres negras, $9,9 \%$, visto que as políticas de ação afirmativa contribuíram para que houvesse um aumento. No mercado de trabalho não poderia ser diferente, dado que a educação/ensino formal é a porta de entrada, ou direciona os postos de trabalho e quem deve ocupá-los. Tendo já observado que mulheres negras estão em desvantagem de acesso, o Retrato mostra que, quando se trata do trabalho formal, aquele com registro em carteira, os brancos saem na frente com $43 \%$ e são apenas $25 \%$ de mulheres negras com carteira assinada.

A inserção no mercado de trabalho tanto de mulheres como de homens negros aumentou significativamente, no entanto, cerca de $34 \%$ das mulheres negras estão empregadas nos serviços sociais, aqueles que abarcam o cuidado, como os serviços domésticos, educação, saúde. Já 13\% dos homens negros, em 2009, estavam lotados na construção civil. Pesquisadores do Retrato indicam que:

Essas considerações preliminares permitem concluir que as mulheres têm consolidado, ao longo das últimas décadas, sua participação no mercado de trabalho no Brasil, que deixa, aos poucos, de ser percebida como secundária ou intermitente. A inserção das mulheres nesta realidade é, no entanto, marcada por diferenças de gênero e raça. Além de estarem menos presentes do que os homens no mercado de trabalho, ocupam espaços diferenciados, estando sobrerepresentadas nos trabalhos precários. Ademais, a trajetória feminina rumo ao mercado de trabalho não significou a redivisão dos cuidados entre homens e mulheres, mesmo quando se trata de atividades remuneradas, o que pode ser percebido pela concentração de mulheres, especialmente negras, nos serviços sociais e domésticos (Ipea, 2011, p.27).

As nossas conversas e entrevistas com as gestoras aconteceram no ambiente escolar e fora dele. Era início do semestre, momento de planejamento, e as aulas ainda não haviam iniciado. Foram momentos importantes, tanto para a minha pesquisa, quanto para elas, pois puderam relatar suas experiências de vida e profissional, fatos que, segundo elas, ninguém nunca havia perguntado:

Eu fiquei ansiosa para esta entrevista, não sabia o que você ia perguntar, mas tá sendo bom! Ninguém nunca perguntou sobre como eu me tornei professora e depois diretora de escola. A minha luta foi grande e nossa profissão não é valorizada (Maria Firmina dos Reis). 
As pessoas precisam saber como chegamos até aqui. É muito diferente das diretoras de São Paulo ou do Rio, por exemplo. A gente teve que aprender na raça, não é fácil comandar uma escola, ainda mais aqui em Laranjeiras (Esperança Garcia).

A formação que fui acompanhar em Laranjeiras, e que me deu a oportunidade de conhecer as gestoras do município, já havia me dado indícios da formação profissional de muitas delas, mas nesse momento da entrevista pude conhecer de maneira mais profunda a trajetória profissional de algumas, que não é muito diferente das trajetórias das outras gestoras, as quais eu não entrevistei.

Um ponto que me chamou a atenção é que, embora elas sejam diretoras dedicadas (sublinho que elas se autoclassificam como diretoras e não como gestoras, pois como vimos acima, a introdução do conceito de gestão ainda é recente no cotidiano escolar), a profissão de docente não era a primeira alternativa delas. Acotirene queria ser freira e Esperança Garcia, comissária de bordo. O que as impediu de seguir na profissão desejada foi a cor das suas peles, foi o racismo estrutural e estruturante da sociedade brasileira, ou seja, uma forma de tecnologia de poder que promove desigualdades e precariedades fazendo que isso se torne normal, uma espécie de naturalização vivenciada racional e subjetivamente (ALMEIDA, 2018). Essas são mulheres na faixa dos 50 anos de idade. As ideias de empoderamento e representatividade que atualmente tentam deslocar o racismo apontando que a população negra pode e deve estar onde ela quiser, apesar das tensões raciais existentes, não foi possível à época que elas iniciaram suas profissões.

O início da carreira como docentes se diferencia do que chamamos de comum, ou seja, para atuar como professora concursada, é preciso que se tenha uma graduação na área desejada. As gestoras de Laranjeiras começaram a lecionar após o término do chamado ensino regular, hoje Ensino Médio, e se graduaram ou licenciaram após anos na profissão e já como funcionárias públicas da Secretaria de Educação do município. Essa é uma questão educacional recorrente atualmente, principalmente em algumas regiões do país, isto porque, antes do processo de redemocratização, havia outros parâmetros para a carreira de docente da Educação Básica.

No final dos anos 90, com a proposta de universalização do acesso ao Ensino Fundamental, Médio e Educação Infantil e visando a melhoria da Educação Básica no intuito de responder às mudanças econômicas e tecnológicas advindas da 
redemocratização e da abertura econômica, o Conselho Nacional de Educação ${ }^{8}$ deu início a um processo de mudança nos parâmetros da Educação Básica, entre elas a formação de professores.

Por meio de estudos, consulta pública e grupos de trabalho com profissionais da educação de diferentes setores, pesquisadores e Secretarias de Educação de Estados e Municípios foram discutidas, e depois promulgadas em 2002, as Diretrizes Curriculares Nacionais para a Formação de Professores da Educação Básica em nível superior, curso de licenciatura e de graduação plena. O Parecer Técnico que formaliza essas diretrizes apresenta as inclinações e propósitos desses novos parâmetros:

A democratização do acesso e a melhoria da qualidade da educação básica vêm acontecendo num contexto marcado pela redemocratização do país e por profundas mudanças nas expectativas e demandas educacionais da sociedade brasileira. $\mathrm{O}$ avanço e a disseminação das tecnologias da informação e da comunicação está impactando as formas de convivência social, de organização do trabalho e do exercício da cidadania. A internacionalização da economia confronta o Brasil com a necessidade indispensável de dispor de profissionais qualificados. Quanto mais o Brasil consolida as instituições políticas democráticas, fortalece os direitos da cidadania e participa da economia mundializada, mais se amplia o reconhecimento da importância da educação para a promoção do desenvolvimento sustentável e para a superação das desigualdades sociais (Parecer CNE/CP 9/2001 HomologadoDespacho do Ministro em 17-1-2002, publicado no Diário Oficial da União de 18-1-2002, Seção 1, p.31).

Com as novas diretrizes, a licenciatura passou a ter uma nova legislação, constituindo um projeto específico com terminalidade e currículos próprios, diferentes do bacharelado e da antiga formação de professoras.

As novas diretrizes foram promulgadas há quase duas décadas e o Instituto Nacional de Estudos e Pesquisas Educacionais Anísio Teixeira (INEP) mostra que, em 2018, foram registrados 2,2 milhões de docentes na Educação Básica brasileira. A maior parte desses docentes, 62,9\%, atua no Ensino Fundamental. Do total de docentes que atuam nos anos iniciais do Ensino Fundamental, 78,5\% têm nível superior completo (77,3\% em grau acadêmico de licenciatura e 1,2\% bacharelado), 6,3\% estão cursando o Ensino Superior e 11,0\% têm Ensino Médio normal/magistério. Foram identificados ainda 4,3\% com nível médio ou inferior. O INEP também aponta que: "De forma geral, as regiões norte, nordeste e grande parte da região centro-oeste apresentam um menor

\footnotetext{
${ }^{8}$ Fonte: Parecer CNE/CP 9/2001 Homologado- Despacho do Ministro em 17-1-2002, publicado no Diário Oficial da União de 18-1-2002, Seção 1, p.31.
} 
percentual de disciplinas ministradas por professores com formação adequada" (INEP, 2018).

Com a expansão da demanda pelas licenciaturas, as instituições de Ensino Superior aproveitaram a onda e as exigência que as novas diretrizes delegavam e se multiplicaram em todo país, oferecendo cursos com baixo custo e em sua maioria voltados para a licenciatura. Esse fenômeno também trouxe outras questões: com a obrigatoriedade, muitas professoras e professores não tiverem possibilidade de escolher qual curso fazer. A escolha da nova profissão ficou rendida aos cursos que as universidades locais ofereciam.

Fiz magistério modular. Cada módulo dura 45 dias, parecido com um supletivo, tínhamos que concluir dentro de um ano. Aprende, mas aprende pouco. Tive muitas dificuldades, eu não gostava muito do curso. Era o que estava ofertado. Prestei concurso para professora e passei. Quando a UNIT chegou, eu queria fazer pedagogia, mas não consegui porque não completou a turma, aí cancelaram. Fiz história, não era meu sonho, mas... isso foi agora em 2014. E depois pós-graduação em gestão escolar. Emendei para assumir a direção (Anastácia).

A instalação de universidades que oferecem cursos de graduação-licenciatura e pós para docentes em cidades pequenas não é rara no Brasil. A universidade citada pelas gestoras está sediada em Aracaju, capital de Sergipe. Ela oferece formação inicial: bacharelado, licenciatura e formação de tecnólogos e formação continuada em nível de especialização. Essa universidade atende 12 munícipios da região e a maior parte dos seus cursos estão ligados às licenciaturas: letras, história, artes e geografia.

Eu também estudei na UNIT. Os cursos não era o que a população queria. Acabei fazendo letras, mas queria fazer artes plástica e depois pós em gestão na UNIT mesmo... não tinha nenhuma estrutura e funcionava na escola no período da noite. O curso começou a ficar caro, aí não formava turma e o polo daqui fechou (Esperança Garcia).

Quase todas na gestão escolar, diretoras e coordenadoras pedagógicas de Laranjeiras, passaram por esta faculdade e lá se graduaram. Ainda que algumas já tivessem assumido a gestão de uma escola, validadas pela experiência docente, as que 
fizeram pós em gestão escolar assumiram o cargo com a legitimidade do diploma e de acordo com a legislação educacional.

...o bom da UNIT é que todo mundo tem o mesmo aprendizado, pelo menos na graduação. Muitas diretoras e coordenadoras de Laranjeiras são professoras concursadas nos municípios vizinhos. Eu mesmo tô aqui e lá (Esperança Garcia).

Ter uma profissão por meio da educação formal, para população negra, principalmente para as mulheres negras, não foi (e podemos dizer que ainda não é) algo que faz parte do cotidiano das famílias, mesmo com as novas políticas de acesso. Mariléia dos Santos Cruz (2009), enuncia que, ainda nos anos 30 do século XIX, a educação servia, na prática, apenas para a autorreprodução do patriarcado e era um privilégio dos homens brancos. Mesmo que o Estado, à época, ansiasse em concretizar suas ideias e valores civilizatórios, a população negra e indígena, com raras exceções, foi deixada de fora. $\mathrm{O}$ que imperava no século XIX era a legitimação do conhecimento: ler, escrever e contar eram atributos essenciais para o exercício das funções públicas.

No Brasil escravista, negros, indígenas e pessoas com deficiência eram proibidos de frequentar escolas públicas. No entanto, houve leis para favorecer a integração de imigrantes europeus, como a Lei 381.30 de junho de 1955:

Em 8 de maio de 1855, o governo provincial firmou contrato com Casa Vergueiro \& Companhia, regulando as condições para o engajamento de, no mínimo, 150 colonos em famílias da Alemanha, Suíça ou Sardenha, sendo estes agricultores e artífices. Dentre as condições estabelecidas, ficou a cargo da província: o pagamento das passagens dos colonos; morada e sustento até que fossem empregados; socorro aos enfermos; data de terras de cem braças para os solteiros, de cento e cinqüenta para famílias de até três pessoas e duzentas braças a famílias mais numerosas. Além dos benefícios citados acima, no parágrafo $6^{\circ}$ ficou determinada a responsabilidade do governo provincial na oferta de instrução primária nas escolas de primeiras letras para os filhos dos colonos empregados nas obras públicas (Coleção de Leis, regulamentos e outros atos do governo, 1856, p. 150-152).

Após a abolição, o liberalismo, segundo Mariléia dos Santos Cruz (2009), também era um ideal exaltado. As competências individuais para romper a predestinação social eram bem vistas pela elite. Entretanto, essa ideia não combinava com o tempo vivido cotidianamente pela maioria da sociedade, ou seja, os descendentes da escravidão que ainda viviam sob o julgo racista que justificava a escravidão pela falta de capacidade 
intelectual da população negra e, estando libertos, a incapacidade biológica de inserir-se na "sociedade civilizada".

A ascendência da funcionalidade dos saberes elementares, objeto da escolarização fez parte do processo de modernização do Brasil, cuja idéia de civilidade estivera centrada no esforço de adequar a vida cultural do Brasil aos valores e costumes das nações européias, consideradas, numa perspectiva hierárquica, o ápice do desenvolvimento humano. Em contrapartida, almejava-se atingir o maior distanciamento possível da cultura das nações consideradas inferiores, as quais eram identificadas como detentoras de um nível baixo de desenvolvimento que se localizava entre a selvageria e a barbárie (CRUZ, 2009, p.112).

Podemos expandir esse contexto para outras realidades que viveram o sistema escravista. Angela Davis (2016), ao escrever sobre o contexto das mulheres neste sistema e após a emancipação, aponta as perspectivas das mulheres negras estadunidenses em relação a educação. A autora revela que, para a ideologia dominante, a população negra não teria supostamente capacidade de se desenvolver intelectualmente. Proprietários de escravizados, proclamavam que o "estudo iria estragar até o melhor preto do mundo". Entretanto, as mulheres pretas naquela sociedade estudavam escondidas, sorrateiramente:

Nenhuma de nós tinha permissão para pegar um livro ou tentar aprender. Diziam que ficaríamos mais espertas de que eles se aprendêssemos alguma coisa, mas nós circulávamos por ali, pegávamos aquela velha cartilha Webster de capa azul e a escondíamos até à noite e, então acendíamos uma pequena tocha e estudávamos aquela cartilha. Nós também decoramos o livro. Agora sei ler e escrever um pouco (DAVIS, 2016, p.108).

Davis aponta que o anseio em aprender sempre existiu, que a população negra sabia que somente "quarenta acres e uma mula" (foi o que receberam com a emancipação), não seria o suficiente. A luta seria bem mais longa e tensa: por terras, pelo poder político e, principalmente, pela educação. Essa foi a maior prioridade pós emancipação.

A trajetória educacional da população negra no Brasil foi marcada por uma imensa desigualdade. Inicialmente, encontramos casos isolados de ingresso de homens negros, somente homens negros livres maiores de 14 anos e saudáveis, em algumas escolas. Após anos de luta dos movimentos negros, com destaque desde a segunda metade do século $\mathrm{XX}$ ao Movimento Negro Unificado (MNU), aos poucos a população negra, incluindo as mulheres, tiveram acesso, embora ainda restrito, à escola formal e pública. 
Foram muitas questões que envolveram o diálogo com essas profissionais da educação, professoras/gestoras de Laranjeiras. Meu encontro com elas e minhas vivências no território se deram nas duas posições em que me inseri: primeiro como profissional de educação com um olhar antropológico para as atividades educacionais que estavam sendo desenvolvidas e, segundo, como antropóloga pesquisadora. Sigamos... 


\subsection{A Rota dos Povoados: pessoas, tempos, caminhos e paisagens}

Combinamos de nos encontrar na praça central de Laranjeiras às 6 da manhã. Era início do mês de janeiro e o céu estava azul claro, decorado pelo amarelo brilhante do sol. Em todas as manhãs era essa a paisagem. Por conta do calor, os moradores têm o hábito de acordar bem cedo e, aos poucos, eu fui entrando nesse ritmo também. Como eu me hospedava em Aracaju (Laranjeiras não possuía nenhum tipo de hospedarias), remarquei o horário para as 8 da manhã, por causa do meu deslocamento. Elas, as três gestoras, Acotirene, Adelina e Anastácia, que foram transitar comigo pelos povoados do município, acharam o horário impróprio, mas logo aceitaram e entenderam. Eu iria fazer a viagem de Aracaju até Laranjeiras de transporte público intermunicipal assim, para estar lá às 6 horas, demandaria um esforço.

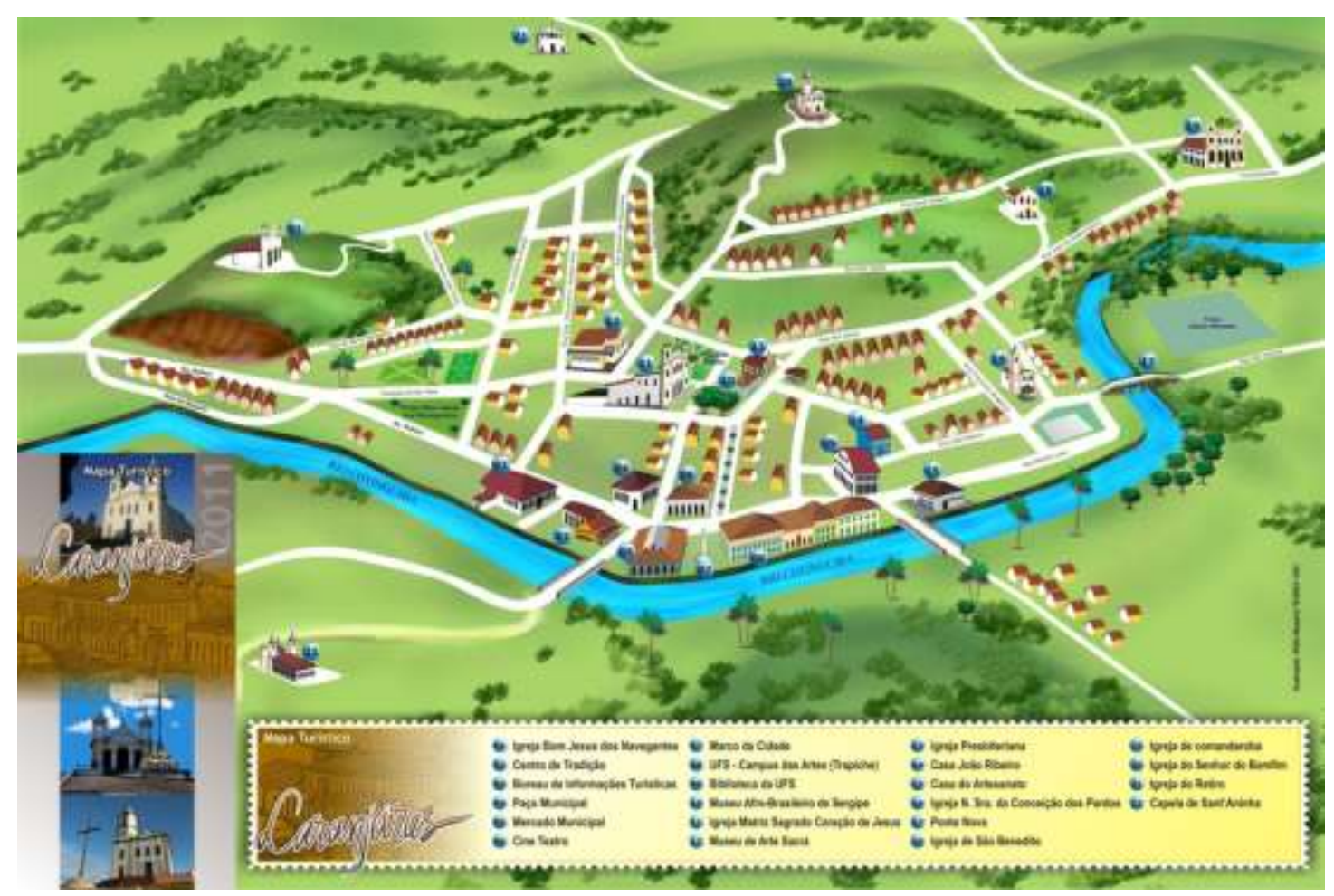

Mapa ilustrado de Laranjeiras. Fonte: http://rildobezerra.blogspot.com/, 2012.

Nosso encontro foi na praça da matriz em frente à Igreja Sagrado Coração de Jesus (a igreja dos brancos), umas das poucas igrejas que, tombada pelo IPHAN, mantem-se conservada e ativa, como relatado no capítulo anterior. Quando eu cheguei, elas já estavam lá sorridentes e dispostas. Planejaram uma rota e me disseram que foi "legal" 
fazer isso, pois conseguiram rever o quanto a cidade é bonita e interessante e, também, fazia tempo que elas não circulavam nos povoados a que iríamos.

Povoados são bairros/comunidades distantes do centro. Ficam geralmente nas zonas rurais. Em todos eles há escolas e muitas histórias. Não era apenas as escolas que me interessavam, mais que isso, era a vida, o cotidiano das e dos citadinos moradores da região. Em cada povoado um céu, uma história, um jeito de viver.

Meu interesse pelos povoados começou a partir do próprio nome "povoado". De início (e talvez até o momento), eu não entendia porque as gestoras chamavam esses bairros/comunidades/quilombos de povoado. Eu sempre ouvia: "fulana é diretora da escola do povoado", "os estudantes do povoado são os melhores" ou "ninguém quer ir trabalhar nos povoados”. Quando eu pedia uma explicação mais nítida do que eram os povoados, as respostas eram: "povoado é povoado", "se é povoado é porque não está no centro", ou ainda "lugar que tem mais famílias que vivem da roça e da pesca" e "são pessoas mais simples, mais pobres, também, mas muito acolhedores”.

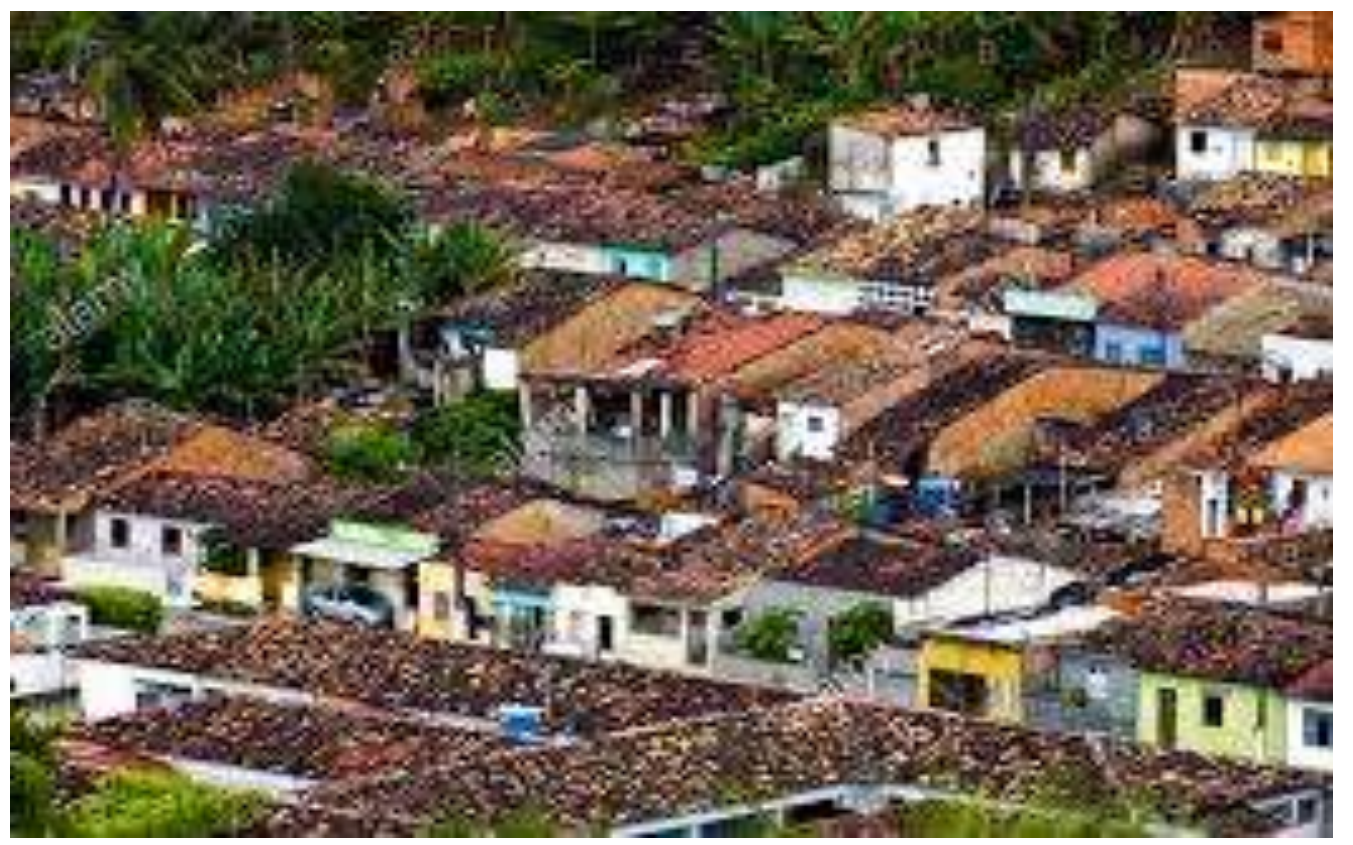

Imagem das moradias no Povoado de Camaratuba. Fonte: https://www.alamy.com.

Eu precisava conhecer os povoados, estar lá, ver as gentes. Outro ponto que me despertou a curiosidade sobre os povoados foi o fato deles não aparecerem no mapa do município e nem no mapa turístico. Era como se só existisse a região central de Laranjeiras, ou seja, um povoado urbano, talvez. No Capítulo 1, falamos sobre os pontos turísticos e as paisagens. Vamos ver agora que alguns povoados que, embora não 
apareçam no mapa, são os principais responsáveis pelo movimento artístico e cultural da cidade e grandes geradores de renda. São eles: Mussuca, comunidade quilombola já explorada acima; povoado Bom Jesus, povoado Pastora, povoado Camaratuba, povoado do Cedro, povoado Várzea e povoado Pedra Branca.

Nesse percurso, deparei-me com pessoas e paisagens deslumbrantes. Os povoados são habitados em sua maioria por descendentes de africanas e de indígenas. Um território afro-ameríndio com muitas histórias. As crianças andavam e brincavam nas ruas de terra, as pessoas mais velhas me ofereceram água, café e me contaram histórias da sua vida, dos seus antepassados e da escravidão. As escolas eram simples, com professoras dedicadas que atravessavam a cidade para ali estar.

Os sorrisos e as gargalhadas constantes daquelas pessoas quase esconderam da minha vista a situação de pobreza estrutural, sem saneamento básico adequado, sem coleta de lixo, alto desemprego, pescadores sem poder pescar por conta da poluição dos rios e/ou recebendo uma miséria dos atravessadores do mercado de peixe. Tinha muita alegria, mas muita tristeza e angústia.

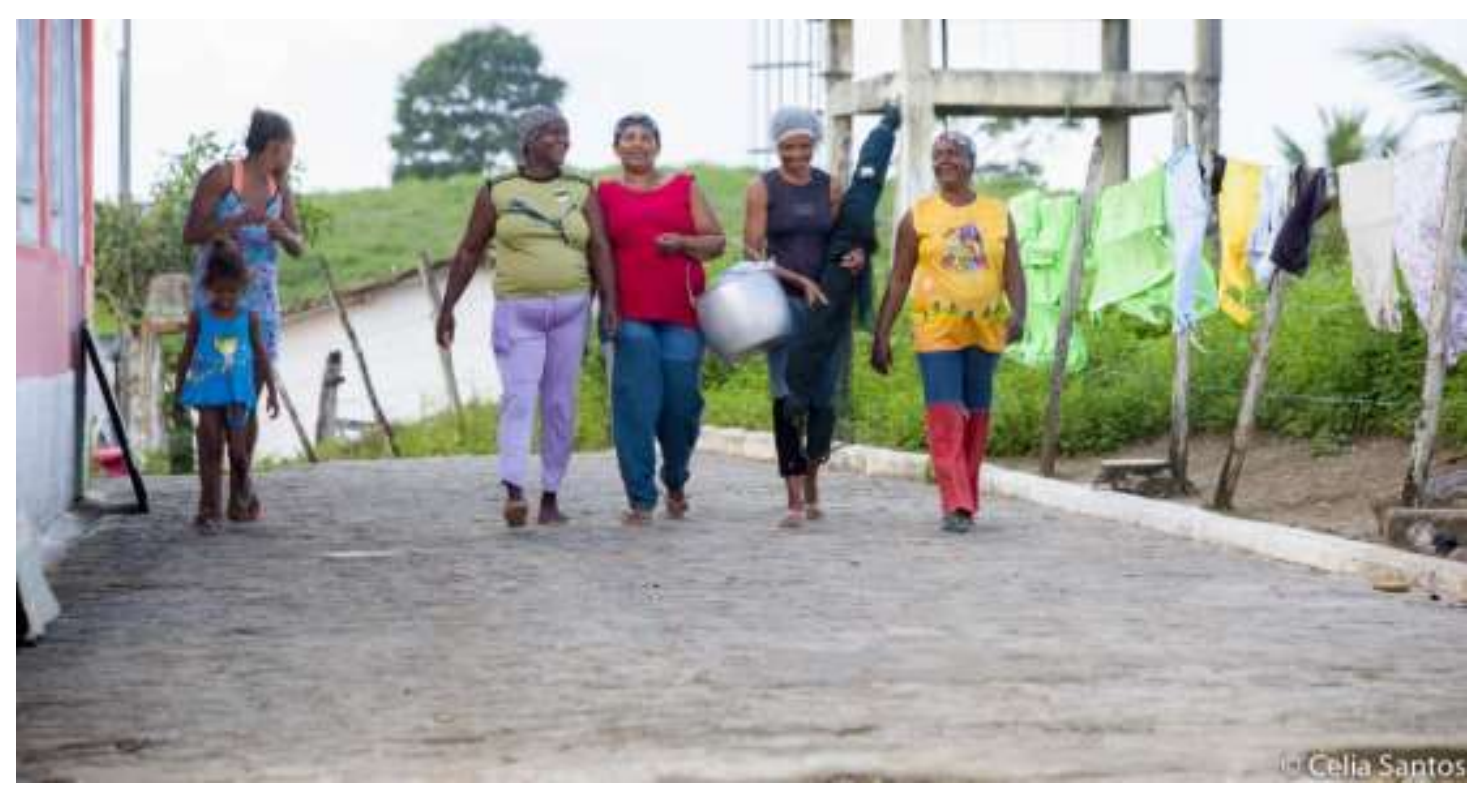

Mulheres marisqueiras do Mangue da Mussuca, foto de Celia Santos/Instituto Mpumalanga. Fonte: https://mpumalanga.com.br/identidade-brasileira-comunidadesquilombolas-tem-futuro-ameacado/.

De acordo com dados de 2017, a população ocupada no município de Laranjeiras era de $22.3 \%$ e o salário médio dos trabalhadores formais era de 3,25 salários mínimos. 
Em 2010, o Censo apontou que o saneamento sanitário adequado dos domicílios era de apenas $36,6 \%$.

Conheci mulheres, de todas as idades com histórias e vivências que dariam excelentes roteiros de filmes, belas poesias, promissoras novelas. Uma beleza de estética e de vida acinzentada pela luta diária da sobrevivência. A cultura é pulsante e são elas que atiçam essa pulsação. No povoado do Cedro, por exemplo, o Reisado (ou a folia de reis) é comandado, organizado e preservado por elas, com muito orgulho. Os valores religiosos, e posso dizer, a intersecção de diferentes concepções religiosas, foi uma característica observada por mim, nesses povoados em que transitei.

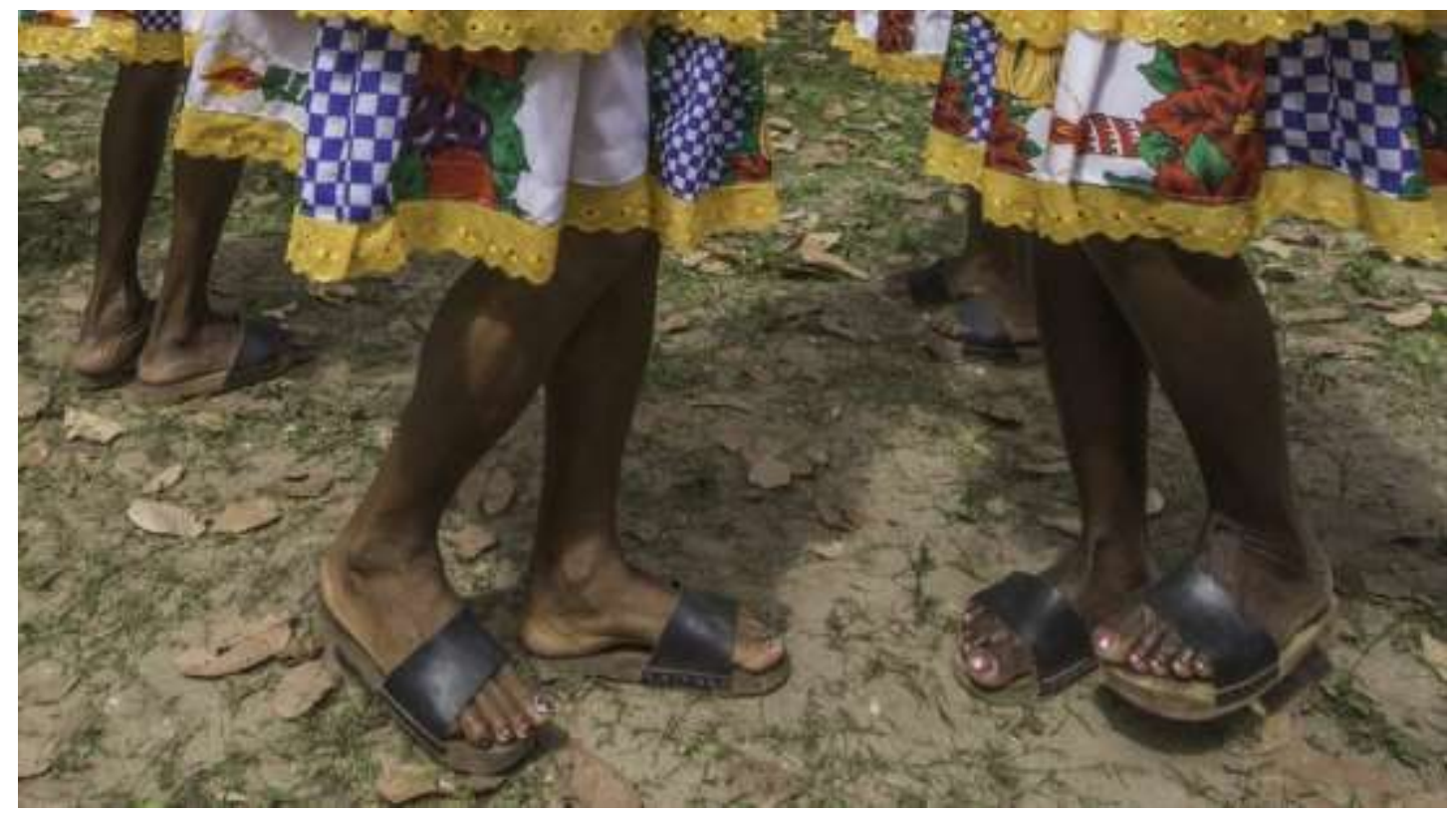

Samba de Pareia da Mussuca, foto de Artur Farias/Instituto Banese. Fonte: https://www.portal79.com.br/sergipe/o-samba-de-pareia-da-mussuca/.

Nas escolas rurais e quilombolas que eu conheci, embora fosse ofertado ali uma educação consistente, o currículo não estava alinhado com as novas propostas educacionais que dizem respeito às diversidades e, para além disso, de respeito às singularidades de cada território. 


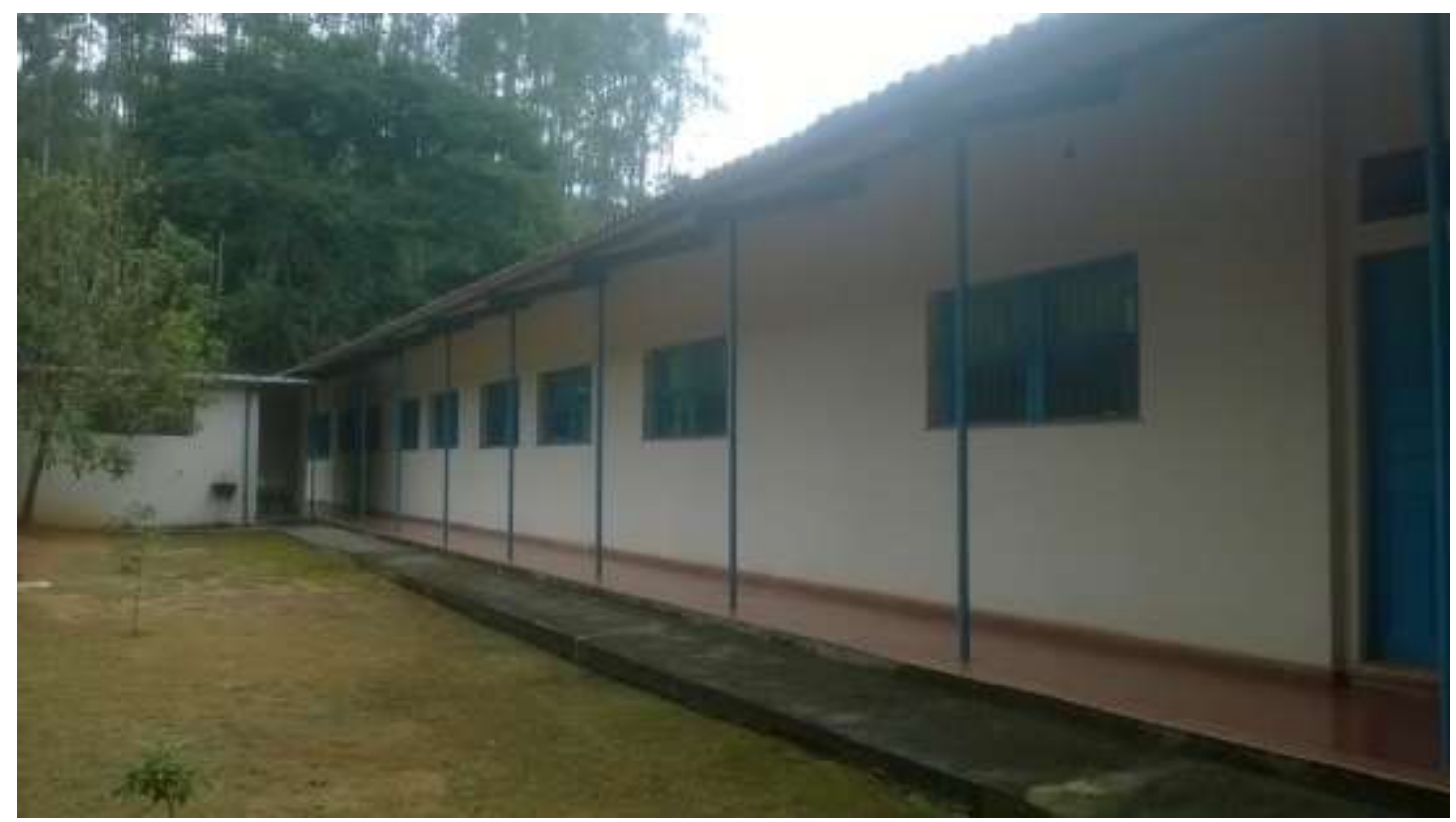

Escola de Mussuca. Fonte: Valéria Alves, 2017.

Chamou-me a atenção que, embora, as estudantes e as docentes das escolas fossem em sua maioria pessoas pertencentes à população negra, ou afro-indígena, os currículos estavam e ainda estão estruturados em uma perspectiva eurocêntrica onde negras e negros estão excluídos tanto nas relações vividas no ambiente escolar, quanto nos livros didáticos e nos diversos materiais utilizado.

Acerca desse assunto, é fundamental pontuar a importância da Lei 10.639/2003 que dispõe sobre a obrigatoriedade do ensino da história e cultura africana e afrobrasileira na educação básica de toda a rede educacional pública e privada do Brasil e da 11.645/2008 que prevê o ensino da cultura afro-brasileira e indígena, tanto no Ensino Fundamental quanto no Médio. É digno de nota que tal feito é resultado de luta, discussões e muitas ações, tanto da população negra de modo geral, quando de pesquisadores negros, principalmente ligados ao sistema educacional, que militaram e trabalharam para a implementação desta no âmbito educacional. A Lei 10.639/2003 que altera a LDB 9394/96 e torna-se obrigatória e essencial nos currículos.

Essa lei, que já tem dezesseis anos, vem sendo implementada a passos lentos, pois enfrenta grandes obstáculos: pela ideia ainda muito presente da existência de uma “democracia racial" no Brasil; pelos argumentos que dizem que falar em raça nas escolas pode suscitar um separatismo entre os estudantes; e pela frente de mais resistência à implementação da Lei, a comunidade evangélica, que argumenta que estudar a história 
dos povos africanos e da população afro-brasileira é obrigar as e os estudantes a aprender e praticar religiões afros, as quais essas educadoras abominam.

Agentes da sociedade civil organizada pela educação, militantes negros de diferentes segmentos, membros de Ministério Público, associações e entidades ligadas à educação fazem um duro enfrentamento a esses argumentos e obstáculos apontando a obrigatoriedade da implementação da Lei no sistema de ensino e nas escolas acionando, inclusive, o Ministério Público quando há denúncias de recusa de escolas e de municípios em trabalhar com a questão.

O que vemos são muitos esforços e poucos avanços. Num período em que a sociedade está passando por um processo de retrocesso, em um momento em que política e religião estão cada vez mais imbricadas, a laicidade na educação escolar (se é que algum dia existiu), está cada vez mais difícil de assegurar.

Retomando nosso percurso pelos povoados, meu diálogo com as gestoras/interlocutoras que me conduziam foi intenso e produtivo para esta pesquisa. Elas falavam sobre o município e sobre o trabalho nas escolas. Me contavam coisas sobre a vida escolar e me consultavam sobre como melhorar suas atividades no trabalho, como era o sistema educacional de São Paulo e, principalmente, relataram suas aflições com as parcerias da prefeitura em projetos que não atingiam, de fato, a comunidade escolar. Veremos esta questão no próximo capítulo. Em algum momento da conversa, Acotirene me disse:

Aqui é como se fosse outro tempo. Já tem internet e celular, mas é outro tempo. Se eles (parcerias e projetos) querem que a gente melhore de acordo com o tempo deles, então, precisam entender o nosso tempo também. Nem tudo está globalizado como passa na TV. Eu preferia que minha escola tivesse descarga no banheiro do que sala de informática e para quê computador se não tem internet.... ahhh, não é a gente que está fora do tempo, eles é que estão. 


\subsection{O Cotidiano: embates, cores e identidade}

Tem um aviso no meu coração: quem não dança conforme o ritmo da casa, não perca seu tempo tocando a campainha.

- Maria Bethânia, Show Drama, Luz da Noite

O cotidiano das gestoras de Laranjeiras circunscreve-se em três movimentos: a família, a escola e a cidade. Há uma intersecção desses movimentos, pois, um não está deslocado do outro no cotidiano. Quase sempre algum membro da família frequenta a escola que elas trabalham, como estudantes, professoras ou funcionárias.

Durante as entrevistas que realizei, parte delas nas escolas, pude perceber o quanto essa relação tríade já estava estabelecida. Por vezes, não se distinguia em qual momento era a gestora que estava ali falando, em qual era a "mãe de família" e em qual era uma citadina reclamando de algum tipo de infraestrutura que não estava funcionando na cidade.

Pelo fato de termos muitas interrupções, afinal, era horário de trabalho das profissionais, tive a oportunidade de ficar mais tempo na companhia de algumas delas e observá-las em seu ambiente de trabalho. Meu contato anterior à pesquisa foi o de "professora" e elas estudantes, contato esse no qual há, de alguma forma, uma hierarquia instalada. Lá nas escolas, no território delas, essa relação foi reposicionada.

$\mathrm{Na}$ primeira entrevista em uma das escolas de Ensino Fundamental I e II, tive a “oportunidade" de presenciar um conflito envolvendo uma situação de racismo. Uma mãe de aluna que estava no sétimo ano foi rematricular a filha fora do prazo estipulado. Ela obteve uma negativa da funcionária responsável, então foi falar com a diretora.

Impaciente e nervosa a mulher interrompeu nossa conversa, pois, segunda ela, não poderia esperar. Era uma mulher jovem, negra (heteroclassificação) que morava em Camandaroba, bairro que eu já havia visitado algumas vezes durante minhas idas ao município, por conta do meu interesse em ver a Igreja de São Benedito, a Igreja dos Pretos. Em minhas visitas a esse bairro, sempre fui alertada que lá era um lugar perigoso. Que havia muitos assaltos e assassinatos. Embora não me parecesse perigoso e sim uma região mais pobre em infraestrutura, fui prudente.

A mãe da estudante disse que demorou para fazer a matrícula porque a filha não queria estudar mais naquela escola, e como ela não conseguiu vaga em outra, voltou para rematricular a filha. A diretora quis saber o que tinha ocorrido e eu também! Então, a mãe da estudante relatou que havia um grupo de meninas e meninos na sala de aula dela que 
a xingavam de feia, fedida e riam do cabelo dela. Essa situação estava ocorrendo desde o ano anterior e, por mais que mãe já tivesse reclamado, nenhuma providência fora tomada. A mãe exclamava: “isso é racismo, é racismo!”.

A diretora, mulher negra (heteroclassificação), disse para a mãe que não tinha a ver com racismo pois quase todos os alunos ali eram negros. Enfatizou que a filha dela ficava muito isolada e, por isso, os outros alunos "mexiam" com ela. A mãe não se conformou com a resposta da diretora, mas conseguiu a autorização para fazer a rematrícula da filha.

Lembrei-me que eu já havia escrito em meu caderno de anotações uma situação de conflito racial na escola durante o ciclo formativo que acompanhei no município. Aqui está:

A palavra racismo apareceu de forma significativa nas falas das gestoras e das estudantes. Das dezessete escolas que participam do programa, quinze delas escolheram trabalhar com os indicadores das relações raciais na escola. Os argumentos utilizados para justificar a escolha foi que há muito racismo nas escolas de Laranjeiras entre as e os estudantes e entre as funcionárias e educadoras. Entretanto, esses argumentos só apareceram depois de um processo formativo e de convencimento de que era importante falar sobre as relações raciais nas escolas e consequentemente no município.

Neste primeiro encontro, eu não consegui capturar a acepção desse racismo que me apresentaram, elas também não conseguiram organizar em palavras como era esse racismo vivenciado nas escolas. Combinamos de fazer uma roda de conversa no próximo encontro para falarmos sobre isso.

(...) Nas oficinas com as e os adolescentes, em uma dinâmica, perguntei o que mais as deixava felizes na escola e o que mais deixava tristes. Sete adolescentes de diferentes escolas disseram que o que deixava mais triste era o racismo. Para mim, foi surpreendente, porque naquela turma, a meu ver, o número de estudantes brancas ou não negras era de uns $10 \%$, e os outros $90 \%$ negras e negros.

Quando perguntei como era o racismo que elas sofriam na escola, a resposta girou em torno da estética, cabelo, lábios, do local de moradia, em bairros mais afastados que eles chamam de povoados e pela dificuldade de aprendizagem.

"Professora eu fico triste porque os meninos não têm respeito, fica xingando a gente de neguinha”; “(...) as meninas do quinto ano puxa meu cabelo na hora do recreio e fala 
que é de Bombril, mas o dela é de chapinha”; "tudo elas falam que a gente mora na roça, no mato (...)"; "prô, tem muito racismo aqui".

Esse foi o meu primeiro panorama sobre as relações raciais em Laranjeiras. Com certeza, uma investigação mais profunda vai nos revelar questões preciosas sobre as ideias de raça, racismo, sobre as diferentes formas de constituição das relações raciais.

A autoclassificação de cor/raça era uma das perguntas que fazia para as gestoras. Durante a entrevista, perguntei a uma delas como ela se autoclassificava e ela respondeu: eu sou morena, meu pai era moreno claro e minha mãe preta, eu puxei meu pai, mas minha avó e meu avô, tanto por pai e por mãe era índio. Não pude deixar de me espantar, pois, na minha percepção, não havia nela nenhum traço de miscigenação. Ela continuou:

Acotirene - No fim, aqui todo mundo é negro, por causa dos escravos, e índio, por conta dos que viviam aqui, nas matas em torno do Vale do Contiguiba. Minha avó foi escrava, mesmo quando já tinha acabado a escravidão aqui na região. Escravidão ficou aqui ainda durante muito tempo. Só quem tinha instrução e dinheiro conseguia sair fora... Mas você mesmo vê, né? A cidade só tem gente preta e as festas quem faz é a cultura dos negros... As pessoas vêm pra cá procurando a cultura negra, então, às vezes, até os brancos querem ser negros, o problema que eles não iam aguentar o que a gente já passou e o que a gente passa. Você tá vendo aí o desemprego.

Valéria - você me disse que todo mundo aqui tem descendência negra e indígena, existe algum tipo de conflito entre as pessoas? Conflitos raciais?

Acotirene - Tem sim, mas tem pouco! No começo, no meu começo, quando eu me aproximei das lutas negras, falando mais politicamente, tinha muita confusão porque algumas pessoas, que já vinham de outros movimentos negros, não aceitavam quem se declaravam afro-indigena... Falavam que isso poderia enfraquecer o grupo e demorou um tempo, depois de muita briga, pra todo mundo entender que aqui em Laranjeiras é diferente... A gente é assim, negro e indígena, talvez menos o pessoal da Mussuca, lá acho que não teve mistura, ou teve bem pouca. Lá, pelo que eu sei, as pessoas se casam entre elas, não abrem muito pra quem é de fora. Agora, não sei antes, na época da escravidão, mas acho que não!

Valéria - Entendi.

Acotirene-Professora, a gente... Nem todo mundo, claro... Mas a gente entendeu que o nosso problema são os brancos, a branquitude que impera nessa cidade. Eles estão na 
política, são os donos das fazendas, já vem de geração pra geração e o nosso povo onde tá? Nos povoados, sofrendo sem esgoto, sem água descente, isso, também vem de geração.

Valéria - E o que as pessoas, de forma geral, pensam disso?

Acotirene - Há! Tem gente que vai pra cima, mas muita gente tem medo. Como a gente já comentou com você, o coronelismo aqui é vivo e bem presente. Para mim, é um novo tipo de escravidão, mas só que essa você recebe salário, mas tem que obedecer... Só vamos mudar isso no voto mesmo! Eles dominam tudo, você pode ver... Na Secretaria de Educação, os melhores postos estão com os brancos, todos os cargos de chefia, em outras secretarias também... A gente tem que mudar isso, a branquitude impera aqui desde a escravidão, uma hora tem que acabar.

Valéria - Você fala sobre branquitude, o que você quer dizer com branquitude, me fala mais sobre isso?

Acotirene - Bom, eu sei que tem várias formas de falar sobre branquitude, que tá na moda... Pra mim, branquitude são essas pessoas que são privilegiadas desde que nasceram. Por serem brancas, depois por serem de famílias brancas com condições financeiras estabelecidas e depois por ocuparem bons cargos. Para mim, o problema é que fica sempre tudo entre eles, para os pretos e pobres nada! Por isso é importante os movimentos, trazer mais gente pra conversar e enfrentar o racismo de frente, aqui em Laranjeiras tem muito racismo...

Os conflitos raciais em Laranjeiras aparecem com esses contornos em outras falas. Vejamos:

Acotirene, moradora de Laranjeiras, disse-me que é mulher afro-indígena “privilegiada”. Conta que sua mãe foi empregada doméstica na casa de uma família na capital, Aracaju. Morando com ela durante a semana no emprego, teve a oportunidade de estudar em bons colégios junto com as "filhas da patroa". Contou-me que ela vivia duas realidades distintas: "a vida dos brancos", durante a semana, e "a vida dos pretos", nos finais de semana, quando voltavam para casa. Segundo ela, essa convivência a adoeceu com o passar do tempo. Por conta do seu cabelo "liso”, causava dúvidas entre os pretos sobre sua negritude, mas, entre os brancos não tinha dúvidas que era negra e a tratavam como "a branquitude trata a população negra". Conta que mesmo assim conseguiu lidar com a situação vivida com o seu núcleo negro, de maneira bem 
diferente da experiência com o meio branco, com quem ela conviveu durante anos, principalmente no ambiente escolar:

"Eu era chamada de feia e beiçuda... não era convidada para as festas das minhas colegas de escola. Eu ficava triste, mas minha mãe me consolava dizendo que eu era a mais linda de todas, que elas tinham inveja de mim, tinham medo que eu me destacasse na festa mais do que elas... Por muitos anos, eu acreditei nessa história, até chegar minha fase de namorar e me deparar com mais violências baseadas nos estereótipos inventados pela branquitude. (...) Sofri todo tipo de maltrato que as mulheres negras, pelo menos as que eu conheço, sofrem... Pra você ver, dei meu primeiro beijo aos 17 anos, um homem branco mais velho, nem os pretos que eu conhecia queriam namorar comigo, tinham vergonha. (...) Então eu fui me virando, li bastante, entrei para o Movimento Negro, reconheci minha beleza e minha raiz afro-indígena, fui atrás de tudo isso, até mesmo para me empoderar frente aos meus colegas negros que questionavam o meu cabelo liso.(...) Mas eu venci, me formei, sou jornalista, e assumi um cargo em uma Secretaria Municipal de Laranjeiras. Pena que muitas amigas da minha idade, acho que a maioria, não conseguiu se livrar das garras da branquitude. Pra você ver, mesmo as que moram na Mussuca, que vivem toda a cultura de lá, que têm família que participa da tradição cultural desde sempre, elas alisam o cabelo, têm vergonha do nariz, se espelham no modelo de beleza das mulheres brancas .Com os homens é a mesma coisa e só não casam com as brancas, porque elas não querem eles. Isso tudo, professora, é legado da escravidão, da branquitude (...). A gente tem nossos movimentos, nossa negritude é forte no Brasil e aqui em Laranjeiras também, ganhamos muitas lutas nesse Brasil afora, mas precisamos fortalecer nossa negritude para acabar com a branquitude... Precisamos proteger nossas crianças..."

Este relato suscita e aponta para discussões importantes sobre as relações raciais. Por vezes, quando falamos em negritude, expressa-se algum sentimento ou adjetivo à população negra, por exemplo: “é lindo ver a negritude nas ruas com seus cabelos crespos" ou "essa negritude de hoje está bem organizada". Entretanto, negritude é um movimento importante para as lutas e reposicionamentos de ideias e perspectivas da população negra em todo mundo.

Jaqueline Lima Santos (2011) aponta que a Negritude é um movimento iniciado na França. O objetivo principal era a de contradizer a marginalidade e agenciar uma volta às origens, preocupando-se com a realidade da população africana na diáspora. 
A negritude nasce de um sentimento de frustração dos intelectuais negros por não terem encontrado no humanismo ocidental todas as dimensões de sua personalidade. Nesse sentido, é uma reação, uma defesa do perfil cultural do negro. Representa um protesto contra a atitude do europeu em querer ignorar outra realidade que não a dele, uma recusa da assimilação colonial, uma rejeição política, um conjunto de valores do mundo negro, que devem ser reencontrados, defendidos e mesmo repensados (MUNANGA, 2009, apud SANTOS, 2011, p. 63).

No Capítulo 4, teremos a oportunidade de debater com mais profundidade as adjacências que conferem as discussões estabelecidas no campo racial. Lá são retomados alguns contornos e as trajetórias conceituais que alinham e ajudam a interpretar as cenas aqui trazidas. 


\subsection{Coordenadas e Estratégias de Fora para Dentro: a educação no olho da globalização}

Minhas reflexões sobre o tempo e, principalmente, sobre os tempos da educação ficaram mais aguçadas a partir dos diálogos com essas mulheres. Veremos mais à frente como funcionam esses tempos da educação e como e por quem eles são coordenados.

Libâneo, Oliveira e Toschi (2012) apontam que existem questões atuais que interferem na educação escolar publica, são elas: o neoliberalismo, a globalização e as questões tecnológicas. A revolução tecnológica é um desafio para a educação pois não se trata apenas de equipar as escolas com computadores, por exemplo. Os autores colocam a sociedade atual como "técnico informacional, ou sociedade do conhecimento".

Neoliberalismo, segundo os autores, é um conjunto de políticas e ideias capitalistas que defendem o princípio do livre mercado e a pouca intervenção do governo nas políticas além da abertura da economia, ou seja, total liberação do comércio internacional, privatização das empresas estatais, abertura da economia para empresas multinacionais, diminuição do tamanho do Estado. A globalização caracteriza-se pelo processo de aproximação entre diferentes sociedades e nações, nos âmbitos culturais, sociais e econômicos, caracteriza-se, também, pela conexão de mercado entre países.

Esses três pontos, revolução tecnológica, globalização e neoliberalismo, aconteceram praticamente ao mesmo tempo, como isso, a educação, na concepção neoliberal, torna-se um problema econômico e uma questão central para o desenvolvimento dos países, tornando-se também, um fator de exclusão social. No processo produtivo neoliberal, profissionais considerados não qualificados ficam de fora. Surge, mais fortemente, a ideia de qualificação atrelada à educação. A nova profissional tem que ter alguns requisitos, como capacidades intelectuais e tecnológicas dentro dos parâmetros do mercado, ser multifuncional, versátil, flexível.

Com esses novos parâmetros, a qualidade da educação atrela-se também às tecnologias. A produtividade, eficiência e competividade, comandam esse sistema. Neste esquema, a educação passa do viés de formação cultural do ser humano e inclusão e promoção da cidadania e vira mercadoria com foco na competividade e no desempenho individual.

Neste novo modelo, as competências e habilidades passam a ser o foco da educação. Aos países periféricos, segundo Libâneo, Oliveira e Toschi (2012), é imposto o Estado mínimo nas áreas econômicas e sociais, assim, muda-se o rumo dos novos 
processos educativos. No entanto, este movimento aumenta a exclusão social, como o desemprego, baixos salários, sistema de saneamento básico precários. A lógica da exclusão via tecnologia e educação se assentam e o papel do Estado e seu poder de ação se perdem nesses meandros.

Para os autores, a questão central da educação a partir dos anos de 1980 passou a ser a qualidade, mas dentro do padrão capitalista neoliberal, ou seja, dentro dos padrões do mercado, principalmente o internacional. Um marco fundamental para a educação brasileira foi adotar a educação em 1990 como algo que deveria se ajustar às exigências do mercado, com isso, a qualidade educacional veste de vez a lógica economicista: deixa de ser um direito universal e passa a ser tratada como mercadoria. As estudantes passam a ser clientes da escola e não mais parte dela. Apesar disso, a escola não pode ser tratada como uma empresa, pois lida com culturas, tradições e tem a obrigação e o dever, por lei, de garantir a aprendizagem de todas, sem exceção, e promover a capacidade de questionar e transformar sua realidade e a sociedade (LIBÂNEO, OLIVEIRA \& TOSCHI, 2012).

As políticas públicas educacionais são um terreno móvel, assim como a legislação que as regem. São um conjunto de disposições, procedimentos e medidas reguladas pelo Estado. De forma geral, as políticas públicas têm uma direcionalidade e, no Brasil, o foco das políticas educacionais são as questões escolares. Entretanto, temos outras políticas que trazem impactos, como o Bolsa Família, que condiciona o recebimento da bolsa à permanência das crianças na escola.

Toda política é construída a partir de influências nacionais e internacionais que pressionam o fazer das políticas públicas. Podemos colocar neste grupo os movimentos sociais de diferentes tipos e os lobbies da iniciativa privada. Política nunca é algo estático, tem suas transformações e interpretações nas diferentes regiões e ao longo do tempo. As interpretações dependem das estruturas locais. É possível averiguar que a política tem uma tensão de cima pra baixo e de baixo para cima.

Neste jogo, temos que levar em consideração os organismos internacionais como a Unicef e o Banco Mundial. Este último busca padronizar as iniciativas educacionais por conta da sua ideologia neoliberal, ou seja, o Estado mínimo, que tem a missão apenas de gerenciar as políticas. Os financiamentos são uma característica deste organismo, que funciona em forma de empréstimo, desta forma, a educação toma o corpo de mercado. A ideia da crise é sempre reforçada para a entrada do Banco Mundial. 
No neoliberalismo costuma-se apontar que o Estado é o culpado pela crise, assim, para alcançar a expansão do sistema de ensino e o fim da crise tem que se permitir que as inciativas privadas interfiram na educação.

A universalização do ensino não é mais o problema no Brasil, mas a qualidade. Eficiência e eficácia são os motes do Banco Mundial e outros financiadores que atribuem uma incapacidade do Estado em administrar, dessa forma, a educação como direito humano passa a ser uma mercadoria.

Como indica Coelho (2012), a gestão pública no Brasil tem passado por transformações nos últimos 25 anos, a partir de um processo de redemocratização. Tal processo passa pela Constituição de 1988, ganhando força nos anos 1990, quando vigorava o plano de reforma do Estado. O autor percorre um conjunto de questões relacionadas a esse processo, que retomo a seguir. Antes disso, faço uma pontuação acerca de uma abordagem antropológica do Estado.

Veena Das e Debora Poole (2008) apresentam a concepção de antropologia da margem como uma perspectiva excepcional para entender o Estado. Elas discorrem sobre uma resistência na fronteira, onde as categorias do "Estado" são subvertidas e reconstruídas no cotidiano social de forma imprevisível. Para as autoras, a antropologia da margem fornece este ponto de vista porque sugere que as margens são implicações necessárias ao Estado, da mesma forma, elas acrescentam, que a exceção é componente da regra.

As autoras elucidam que a antropologia, por questões históricas, empenhou-se em estudar os "povos primitivos" como uma não organização ou como uma organização sem Estado. Neste sentido, o Estado aparecia como remoto nas práticas etnográficas que constituem o objeto da disciplina, por vezes concebida como uma disciplina que fala dos povos marginalizados pelas estruturas econômicas e políticas dos governos coloniais e pós-coloniais. Das e Poole ressaltam que a etnografia oferece uma perspectiva excepcional que parece desmantelar o Estado e suas margens territoriais e conceituais. A antropologia da margem sinaliza que o Estado não é um bloco monolítico, ele está em constante construção e que há uma criatividade dos atores e/ou grupos vistos como marginais. Estas são perspectivas teóricas que inspiram o olhar que aqui se está tecendo.

No Brasil, importantes transformações têm início nos anos 1980, contudo, uma agenda de transformações para o setor público-estatal só foi intensificada no pós-95. Tal agenda incluía a governança pública, a gestão fiscal, e a modernização institucionaladministrativa. Em 1995, no governo de Fernando Henrique Cardoso, o Plano Diretor da 
Reforma do Aparelho do Estado configura-se como um marco que intensifica as discussões acerca da Reforma do Estado, dando um norte aos projetos de reformas administrativas, acompanhado da estabilização monetária e do reordenamento fiscal do Plano Real. Este Plano Diretor discute, principalmente, a revisão da Emenda Constitucional $\mathrm{n}^{\circ}$ 19, a apresentação de uma nova estrutura organizacional, a utilização de novas estratégias gerenciais e a renovação da política de recursos humanos.

Como afirma Coelho (2012), essa agenda de reformas, que traz a ideia de uma Nova Administração Pública, iniciou a concepção de administração pública gerencial no Brasil. Esta gestão estabelece o desenvolvimento de políticas públicas, assim como a prestação dos serviços públicos.

De acordo com Abrucio (2005, apud COELHO, 2012), tanto a redemocratização, como a descentralização que ocorreram no Brasil a partir da década de 1980, proporcionaram maior importância aos governos subnacionais. Atualmente, os poderes locais são responsáveis pela manutenção das funções básicas atribuídas ao Estado, assim como pelas políticas sociais, sendo então referência estatal para os cidadãos. A partir desta modificação, a agenda primordial no Brasil passa a ser a modernização administrativa dos governos subnacionais.

Tendo em vista a instabilidade dos gastos públicos, considerando os estados brasileiros, fez-se necessário ajuste estrutural, além de mudanças no modelo de gestão, com o intuito da diminuição de custos e melhora na eficiência nas diversas áreas que gerenciam despesas, inclusive a educação. Além disso, as administrações públicas estatais passam a investir em tecnologia de gerenciamento:

Assim, ao sentido de eficiência econômica das reformas de primeira geração agregam-se as orientações de eficácia administrativa melhoria da qualidade dos serviços públicos, por exemplo, que caracterizam as reformas de segunda geração -, bem como, ainda que incipiente, observam-se inovações de terceira geração que introduzem os valores de uma gestão social (sobretudo, a democracia participativa) em processos decisórios das políticas públicas (COELHO, 2012, p.3).

A partir da Constituição de 1988 e a Lei de Responsabilidade Fiscal, que enfatizava um cenário de grande controle de gastos, tem-se buscado maior envolvimento dos governos subnacionais na construção de uma nova gestão pública, estando em desenvolvimento o aperfeiçoamento de um Estado administrativo.

Além das transformações citadas, Coelho (2012) indica que, no setor público estatal brasileiro, a administração pública nacional se transforma acompanhada por um 
crescimento do setor público não-estatal nas políticas públicas e das negociações entre iniciativa privada e a gestão pública, ampliando-se tais negociações entre Estado, terceiro setor e mercado, interligados pelo interesse público.

As organizações de terceiro setor têm crescido no Brasil de duas formas: empreendendo seus próprios projetos sociais ou estabelecendo parcerias com políticas governamentais. Já o mercado vem assumindo posições antes realizadas pelo Estado.

Cada país estabelece sua própria agenda de reforma do Estado, a qual é formulada a partir do processo político de cada um deles, de acordo com questões internas e externas do território em questão. No Brasil, muitos aspectos da reforma seguem em discussão, o papel de regulação do Estado, por exemplo. Outro ponto ainda a ser considerado é elaborar e colocar em prática uma gestão pública por resultados. Por outro lado, o pluralismo organizacional e a responsabilidade fiscal já foram institucionalizados. De qualquer forma, de acordo com Coelho (2012), a gestão pública no Brasil ainda apresenta um aspecto de administração pública patrimonialista. Segundo o autor, o país vive "um pró-ciclo de reformas e inovações, ensejadas politicamente, voltadas para o aperfeiçoamento da administração pública a partir de algumas orientações e princípios" (COELHO, 2012, p. 4).

Nesse novo modelo de administração pública é ressaltada a ideia de Estado-Rede, deslocando a administração pública para uma abordagem mais ampla, de sistema aberto. Um dos grandes desafios do Estado-Rede, refere-se a garantir a qualidade das políticas públicas, assim como o crescimento destas, tendo em vista as limitações pertinentes à ordenação da administração pública na sociedade contemporânea.

Como indica Coelho (2012), o atual modelo de gestão pública está divido em três diferentes grupos: a Orientação para a Eficiência, a qual está relacionada com a dimensão econômico-financeira; a Orientação para a Eficácia, a qual está relacionada com a dimensão administrativo-institucional; e a Orientação por Efetividade, a qual está relacionada com a dimensão sócio-política.

A Orientação para a Eficiência refere-se aos gastos públicos do Estado, o modo como tais gastos não estão padronizados. Relaciona-se ainda às falhas de intervenção do Estado, assim como sua incapacidade ou crise fiscal. Caracteriza-se por processos de privatização e apresenta o ideal de produtividade. Objetiva o estabelecimento de valores para a sociedade, relativos aos contribuintes, que visam o uso coerente dos recursos públicos.

Já a Orientação para a Eficácia apresenta como estímulo as falhas das 
organizações burocráticas que comprometem o retorno das organizações públicas e que acabam por impactar a satisfação da população. Busca qualidade, atuando do melhor modo possível, de acordo com as necessidades e desejos dos usuários finais dos serviços e políticas públicas. Objetiva o estabelecimento de valores direcionados aos usuários das políticas públicas, que almejam do Estado qualidade no serviço a eles prestado.

Por fim, a Orientação para a Efetividade é motivada pelas ausências da democracia participativa, a falta de equidade da gestão de políticas públicas, o não atendimento de direitos sociais, ou as falhas apresentadas quando o serviço é prestado. Busca a realização de um trabalho efetivo ao usuário do serviço, considerando seus direitos sociais como cidadão, apoia-se na ideia do desenvolvimento humano integrado. Estimula os tratos organizacionais, baseados em ações coletivas, norteadas pela autogestão, como economia solidária, cooperativismo e associativismo. Objetiva o estabelecimento de valores direcionados aos cidadãos que almejam a proteção da ação coletiva. Enfatizam que seja público o processo de tomada de decisão do Estado, e que as políticas públicas direcionadas a eles sejam efetivas quanto a transformação social.

As três orientações apresentadas se inter-relacionam por processos de reformas e inovações. As reformas geralmente são estruturais, evidenciam-se por processos decisórios e alianças favoráveis às reformas. Já as inovações, em geral, são pontuais e incrementais, evidenciam-se por processos decisórios e ímpeto favorável a inovações.

Nos últimos anos, tornaram-se rotineiros escândalos de corrupção e a oferta de serviços públicos de baixíssima qualidade. Tal situação vem sendo escancarada nas mídias em geral, estimulando a população a acreditar na ausência de competência política, assim como na falta de habilidade administrativa dos agentes do Estado. A população passa a enxergar o Estado como ineficiente, amoral, oferecendo serviços precários para a população.

Contudo, Coelho (2012) destaca que, no Brasil, há um repertório de ideias inovadoras de gestão pública na atualidade, voltadas a políticas privadas e para a qualidade das organizações. Tal repertório tem sido criado nos último 15 anos, surgindo de concursos realizados por órgão públicos, instituições de pesquisa e ensino e também de organizações do terceiro setor, estando envolvidos municípios, estados e governo federal, assim como os poderes executivo, legislativo e judiciário. Tem como foco a criação de projetos revolucionários, criados e executados pelos mandatários políticos, pelo Estado e pela sociedade civil.

Com isso, Coelho (2012), apresenta uma compilação das alterações na gestão 
pública brasileira, buscando fornecer alguns conceitos contemporâneos, apresentando também sua aplicação na realidade. Destaca que esse novo modelo de administração pública está constantemente em reinvenção, sem previsão de término, como um projeto inacabado.

Veremos no próximo capítulo como todo o repertório citado acima, juntamente com a pesquisa de campo e meu olhar etnográfico sobre o ciclo formativo na educação de Laranjeiras, proveniente de uma PPP, estão emaranhados numa perspectiva colonial de construção de uma nova nação. 


\section{Capítulo 3. Para o Público ou para o Privado? Arranjos e descompassos na educação pública do Brasil}

Minha porta de entrada para as pautas e projetos privados para a educação se deu a partir da minha experiência de trabalho com a educação. Aprofundei-me ainda mais no assunto por ocasião do acompanhamento que fiz do ciclo formativo de uma PPP em Laranjeiras e, depois, por ocasião desta pesquisa. O objetivo deste capítulo é, portanto, analisar as formas e os propósitos das parcerias público-privadas na Educação Básica e pública no Brasil e a recepção dessas parcerias, especificamente na rede municipal de ensino de Laranjeiras.

As atividades do ciclo formativo que acompanhei foram geridas por uma instituição sustentada por um grande e antigo grupo empresarial. Chamarei o grupo de Instituto Cameleão. Os camaleões são répteis pertencentes à família dos lagartos. São conhecidos por se transvestirem de diversas cores para não serem pegos por seus predadores e para enganarem suas presas. Com mais de 80 espécies, os camaleões têm em comum uma língua rápida, grande e forte e olhos que se movimentam para lados diferentes independentemente. Assim, enquanto um olha para sua presa, o outro olha o que acontece nas redondezas. Além de mudarem de cor conforme a situação vivida, os camaleões, assim como as serpentes, precisam mudar de pele de tempos em tempos. No caso deste instituto, ele se transveste para que sua real intenção não seja vista a olho nu e assim seguir com os seus planos. Digo plano, porque, como veremos mais adiante, financiar projetos para a Educação Básica é um plano empresarial com o intuito de “colonizar" as aprendizagens e pautas públicas com o viés corporativo, privado e conservador.

Contudo, o plano vai muito além, ele não está circunscrito apenas aos muros das escolas. Lá, de fato, é a sua base. Entretanto, as políticas nacionais e a ocupação de cargos públicos com influência e poder, penso, são suas metas principais, como acontece de alguns anos pra cá.

Meu percurso neste capítulo é conduzido a partir da minha experiência com o Instituto Camaleão, porém, também analisei outros dois: Instituto Papa-Léguas, que nomeei em referência ao galo-corredor dos desertos norte-americanos, um dos desenhos mais famosos da Looney Tunes, e a Fundação Tarântula. As tarântulas são aranhas venenosas, cujas principais características são sua exuberância e suas pernas longas com garras nas pontas. Junto dessas organizações, apresento também a organização Sapo- 
Cururu, que tem como associados todas as instituições e fundações que trabalham e pautam as políticas educacionais. Sapo-Cururu é o anfíbio mais fértil dessa cadeia animal, chega a botar 35 mil ovos de uma só vez. São venenosos e extremamente tóxicos quando ingeridos. Por conta do apetite voraz, o sapo-cururu foi usado durante muito tempo objetivando o controle de pragas. Atualmente, é considerado, ele próprio, uma praga, afetando os animais domésticos e de estimação. Apresento, por fim, as ONGs Saúvas. As saúvas fazem parte de uma espécie de formigas-cortadeiras, nativas do "Novo Mundo". São chamadas cortadeiras porque cortam pedaços de folhas que carregam para seus formigueiros a fim de criarem um fungo que constitui o seu alimento exclusivo. Elas são uma das mais importantes pragas agrícolas, sendo tão abundante nas lavouras que os primeiros "colonizadores" as denominavam de "o verdadeiro rei do Brasil" " Todas estas organizações têm objetivos parecidos.

Sugiro que, durante trajeto deste capítulo, tenhamos algumas perguntas em mente: 1 - Qual o intuito dos grandes grupos empresariais, que, por meio de seus institutos, oferecem projetos e cursos gratuitamente para centenas de municípios em todo o Brasil?; 2 - Quem de fato é favorecido com esses cursos, o público ou as iniciativas privadas? Como essas pautas ressoam no cotidiano da Educação Básica? Qual o papel do Estado?

\footnotetext{
${ }^{9}$ Fonte: Programa de Sanidade em Agricultura Familiar- Instituto Biológico-2009.
} 


\title{
3.1. Juntos pela Educação - pelos Pobres e Desvalidos: um projeto de nação determinado pela classe empresarial
}

\author{
Eu conheço uma pá de otário metido a malandro que anda gingando, \\ crente que tá abafando, e só aprendeu a falar: Como é que é? Como é \\ que tá? \\ - Bezerra da Silva
}

Em janeiro de 2019, a Instituição Sapo-Cururu realizou um grande congresso em que foram convidadas as principais organizações que trabalham em prol da educação pública brasileira. Foram muitos trabalhos e projetos apresentados. O congresso aconteceu no nordeste do país, em uma ilha frequentada por turistas estrangeiros e pela comunidade hipster, que procura ali um abrigo quando necessita se afastar da cena gentrificada das cidades onde mora. A ilha também é frequentada por pessoas e famílias com nome e sobrenome "influentes" no cenário nacional. As e os participantes do congresso chegaram dois dias antes para aproveitar todos os aspectos da natureza do nordeste brasileiro. Além da paisagem natural, comidas "interessantes" foram servidas, como acarajé, moqueca, carne de sol com queijo coalho, sarapatel e paçoca de carne-seca. A maioria das e dos participantes nunca tinha provado aquelas "iguarias", muitas de origem africana e que faziam parte do cotidiano dos nativos e nativas da ilha. Ficaram surpresos com o sabor e com a complexidade do preparo. Bebidas também foram servidas: cajuína, aluá, tiquira, cachaça local e refrigerante São Geraldo. Foi uma festa!

$\mathrm{Na}$ mesa de abertura, foram convidadas a falar as três grandes instituições que mais elaboram e colocam em prática programas e projetos educacionais com o intuito de melhorar a educação pública. O roteiro foi básico: apresentação da instituição, dos planos e projetos em andamento e mensagem de suas e seus presidentes. Cada instituição tinha um tempo em torno de 20 minutos, a única regra era que não haveria perguntas e debates das e dos ouvintes e participantes. O congresso começou com a apresentação do SapoCururu. Um dos seus gerentes de projetos fez a seguinte apresentação:

Desde 2006, tudo que o Sapo-Cururu deseja é uma educação de qualidade para toda população brasileira de baixa renda. Repetimos sempre em nossos meios de comunicação que: "Somos uma organização da sociedade civil, sem fins lucrativos, plural e suprapartidária. Nosso propósito é melhorar o Brasil, impulsionando a qualidade e equidade da Educação Básica no país. Com a atuação focada em contribuir 
para o avanço das políticas públicas educacionais, buscamos criar senso de urgência para a necessidade de mudança”.

Nós não vendemos produtos e nem recebemos dinheiro público e não somos acionistas de empresas, além disso, não temos projetos em escolas. Nós produzimos conhecimento, avaliamos as ações dos governos, monitoramos a implementação de políticas educacionais. Por meio de nossos projetos, fazemos a articulação da sociedade civil com o poder público. Pautamos questões no Congresso Nacional e participamos ativamente do Plano Nacional de Educação. Muitas famílias e empresas acreditam no nosso plano de melhorar a educação brasileira e contribuem apoiando e mantendo financeiramente nossa Instituição. São elas:

Família Kishimoto, Fundação Bradesco, Itaú Social, Fundação Lemann, Fundação Lucia e Perlerson Penido, Fundação Telefônica/VIVO, Instituto Natura, Instituto Unibanco, Instituto Península, Milú Villela, Scheffer, Antônio Carlos Pipponzi, Editora Moderna, Dpschoal, Fundação Roberto Marinho, Maria Cecília Souto Vidigal, Gol, Cyrela, Instituto Votorantim, Shoulder, além, claro, Instituto Cameleão, Fundação Tarântula e Instituto Papa-Léguas. E somos apoiados pela a maioria das Saúvas espelhadas pelo território nacional. Poderia citar pelo menos mais 15 mantenedores, mas acredito que com esses é possível vocês sentirem o poder da nossa instituição.

Todas essas pessoas, famílias, empresas e instituições têm projetos para a educação pública e lutam por um país mais justo e menos desigual! Nossa presidenta, herdeira de uma grande fortuna, mas que se dedica a melhorar a qualidade da educação pública e se preocupa com os menos favorecidos e com o Ensino Médio das escolas públicas brasileiras, enviou uma mensagem para esse congresso: “... é no Ensino Médio que precisamos aproximar os adolescentes do mercado de trabalho... a gente precisa de mudanças drásticas. Pode dar errado? Pode. De um lado, pode haver perdas. Mas também pode dar certo". Ela é favor do fim do Ensino Médio e apoia o Ensino Técnico para formar trabalhadores.

Durante a fala, refrigerante São Geraldo foi servido em taças com gelos, mini acarajés também foram servidos empratados.

O público do congresso aplaudiu com grande entusiasmo, afinal, todas as instituições ali presentes eram associadas à instituição Sapo-Cururu e sabiam que o trabalho não se realizaria sem a anuência dele. 
Em seguida, o mestre de cerimônias chamou ao palco a instituição que mais avançou em projetos para a educação pública: o Instituto Camaleão. A diretora de projetos fez uma apresentação rápida do instituto e dos programas e projetos. Segue um breve resumo:

O Instituto Cameleão tem um diferencial: nós não patrocinamos projetos de outras instituições e trabalhamos em parceria com as Saúvas. Somos sustentados e apoiados pelas empresas que compõem um grupo empresarial, um dos mais ricos do mundo! Nossos temas são geração de trabalho e renda; cadeia de valores e empreendedorismo, qualificação de ONGs, gestão pública, voluntariado, garantia de direitos, grupos de participação comunitária. Nosso maior programa de investimento é no nosso projeto para a educação pública! Investimos, até o momento, 123 milhões de reais. Nosso público alvo são gestores educacionais, gestores escolares e mobilizadores sociais para provocar a transformação de mentalidade sobre gestão e atingir positivamente professores $e$ alunos das redes públicas. Contamos com a metodologia e ferramentas do Sapo-Cururu. Nosso grande objetivo é desenvolver as competências dos profissionais da educação. Nosso líder enviou a seguinte mensagem sobre o nosso plano: "contribuir para a melhoria da educação pública nos municípios onde há operações do nosso grupo e atuar em parceria com as prefeituras e secretarias municipais de educação”. Nesse projeto, nossos números são expressivos: foram 105 municípios em 17 Estados; 1130 escolas atendidas, milhares de alunos impactados. 162 mil pessoas impactadas.

O Instituto Camaleão (IC) é um núcleo de inteligência social das empresas e trabalha com a geração de valor compartilhado: retorno sobre os investimentos e engajamento comunitário por meio de investidores e das empresas do grupo. O IC atua onde as empresas dos grupos estão estabelecidas, de maneira geral, em municípios de 2 até 300 mil habitantes, mas a grande parte são municípios pequenos, com até 30 mil habitantes. Nossa missão é qualificar a atuação social das empresas, contribuindo para a competitividade dos negócios e o desenvolvimento das comunidades. Empresas e comunidades evoluindo em sinergia!

$\mathrm{Na}$ nossa atuação, buscamos intensificar as alavancas de desenvolvimento socioeconômico das localidades em que as empresas do nosso grupo estão presentes, por meio de duas frentes: gestão social de negócios, que está diretamente ligada à estratégia da empresa, e desenvolvimento local, em que atuamos para fortalecer e qualificar os potenciais de desenvolvimento social do município. 
Durante a apresentação, as representantes das organizações Saúvas escutavam atentamente e balançavam a cabeça concordando com a fala do representante do IC. Logo após, elas e eles tiveram a oportunidade de vivenciar um momento cultural: crianças de uma escola local, cujo município que a abrigava também recebia projetos dessas instituições, fizeram uma linda apresentação. Declamaram poesias sobre a importância da educação, cantaram e dançaram um frevo. Em seguida a esse momento extasiante, o Instituto Papa-Léguas foi convidado a se apresentar. Vejamos:

Nós promovemos a educação integral para que as crianças e adolescentes construam um futuro melhor. Nossa família segue os desejos de proporcionar boas possibilidades para os estudantes das escolas públicas. Entendemos que a chave para preparar as novas gerações nesses tempos cada vez mais dinâmicos e complexos é a educação integral. Com ela, estamos agenciando as competências cognitivas e socioemocionais para que nossas crianças e jovens se desenvolvam de modo pleno no curso das suas escolhas e do bem coletivo. Acreditamos que, através do nosso trabalho, poderemos superar as dívidas educacionais do passado e seguirmos plenos para o futuro. A fundadora e presidenta do Papa-Léguas enviou a seguinte mensagem para os participantes desse congresso: "Acreditamos que as competências socioemocionais e cognitivas fortalecem os alunos para que continuem aprendendo, ingressem no mundo do trabalho e contribuam para o seu entorno social, sabendo resolver problemas, trabalhar em time, enfrentar situações adversas de maneira criativa e construtiva a longo da vida, na escola e fora dela. Tudo isso valorizando a diversidade e o projeto de vida de cada um”.

As gestoras escolares têm um espaço garantido e privilegiado em nosso projeto de construir um mundo melhor. Nosso projeto coloca gestores de 18 município brasileiros em rede. Nesta rede discutimos estratégias de boas práticas da gestão educacional e escolar. Também ajudamos os municípios a elaborarem o plano de educação. É tudo virtual, mas estamos conseguindo melhorar a qualidade da educação pública brasileira. Temos ações para reduzir o atraso escolar, para valorização dos profissionais da educação local, para planejamento e acompanhamento de resultados das aprendizagens e parar a formação continuada. Fazemos o acompanhamento dos indicadores educacionais e metas dos municípios participantes, produzimos e divulgamos conhecimentos e participamos dando destaques aos temas da Nova Base Comum Curricular (BNCC). 
Para tudo isso, usamos nosso centro de inovação, um laboratório que conecta os profissionais da educação com a finalidade de construir conhecimentos e apontar soluções. Nós mesmos que tocamos todo esse projeto, não contamos com as Saúvas e, mais, convocamos toda a população que acredita que a educação é importante para o progresso do país à participação através de doações, que podem ser em dinheiro, notas fiscais de bilheterias das 348 salas de cinema e dos checkouts de hotéis, nos objetos que levam a nossa marca e também contamos com empresas investidoras para o bem, além das redes de fastfood e pedágios espalhados por todo o Brasil. Sem contar que a nossa presidenta fundadora, que já ganhou muitos prêmios pelo seu trabalho em prol das crianças e jovens carentes, herdeira de umas das mais valiosas marcas do país e militante pela educação pública, enviou essa seguinte frase para nós congressistas: "A nossa elite é muito rasa e voltada para si mesma". Vejam, ela tem consciência que a elite brasileira é egoísta, por isso pensa nos desfavorecidos contribuindo com a educação pública brasileira.

Enfim, chegou a vez da organização que mais teve avanços em 2018. Ela que ousou fazer disputas em diferentes cenários políticos para garantir uma boa educação para as e os brasileiros: Fundação Tarântula. Sua representante, a diretora de projetos, uma mulher jovem, linda e saudável, inicia sua apresentação com um forte e meigo: "Namastê!". E segue:

Nossa missão é trabalhar para construir um Brasil mais justo, inclusivo e avançado.

Somos novos nesse território educacional, temos apenas 15 anos de trabalho, diferente das nossas coirmãs. Desenvolvemos tecnologias para uma educação pública de qualidade para todos e apoiamos pessoas e organizações que dedicam suas vidas a solucionar os principais desafios sociais do Brasil. Somos uma organização familiar, sem fins lucrativos, e atuamos sempre em parceria com o governo, com grupos empresariais e com as Saúvas, de maneira plural, inclusiva e buscando caminhos que funcionam na escala dos desafios. Trabalhamos para ajudar o Brasil a avançar. Nosso presidente é um bilionário que se preocupa com a educação dos pobres e pediu para dizer que: "Nós não vendemos nenhum produto educacional, não estamos associados a nenhuma organização privada e não apoiamos nenhum partido político, coligação ou campanha eleitoral. Somos independentes e o nosso foco é que todos tenham uma 
educação de qualidade! Nesses poucos anos de trabalho já impactamos quase 900 mil alunos, e apoiamos milhares de escolas e gestores com soluções inovadoras".

Porém, acreditamos ser importante contribuir com a política nacional, assim, ao longo dos últimos anos, estamos criando lideranças para assumir cargos políticos importantes. Nosso fundador, em algum momento e sem nenhum interesse próprio, sentiu essa necessidade.

Essas lideranças cursaram as melhores universidades do mundo, como Harvard, Oxford, e universidades federais brasileiras. Poderiam assumir qualquer grande cargo no mundo coorporativo, como CEO de grandes empresas, mas preferiram contribuir com a política nacional. Nas eleições de 2018, 7 profissionais da nossa Fundação Tarântula concorreram à cargos eletivos. A campanha eleitoral foi inovadora, eles a chamavam de startup. Nosso presidente fez a seguinte declaração: "Eles sabem que vai ser difícil serem eleitos, mas espero que alguns deles sejam e que isso crie uma corrente de gente boa no governo. Espero que alguns deles cheguem até à presidência do país”.

Não foi tão difícil assim, 6 deles se elegeram para deputadas e deputados federais e estaduais. Suas pautas estão ligadas diretamente à educação. A partir de agora, a política nacional terá novos rumos e a gestão da educação será mais eficiente! Para nós, não importa qual o partido político, o melhor é que estejamos em todos, mas ainda não conseguimos. O que permeia nossas pautas é a busca pela eficiência na gestão.

Ao final, a representante da Fundação Tarântula convidou as e os participantes para fazerem uma grande ciranda em prol da educação. Cirandaram e se emocionaram com a perspectiva de um novo Brasil, mais educado, mais empreendedor e pronto para novas disputas. Dessa forma, deu-se o final do primeiro dia do congresso.

O interessante nessas apresentações foi ver como as instituições, fundações e organizações estão se movimentando no cenário nacional e também conhecer suas pautas para a educação. Julgo necessário fazermos algumas perguntas: por que as famílias e pessoas mais ricas e influentes economicamente do país têm tanto interesse na educação pública? Quais são, de fato, os objetivos de tanta dedicação e dispêndio de dinheiro para os "desfavorecidos"? Essas instituições conhecem de fato a realidade dos municípios e a educação pública brasileira? Como eles veem a participação do Estado em seus planos e projetos? Por fim, qual o projeto de nação que essas instituições estão construindo até agora, e com sucesso? 
Um dos trabalhos mais relevantes que ilustra essa toada é o da pesquisadora Erika Moreira Martins. Em sua pesquisa de mestrado intitulada: Todos Pela Educação: como os empresários estão determinando a política educacional brasileira (2016), e em artigos oriundos dessa pesquisa, a autora enuncia que a entrada dos empresários na educação pública brasileira não é recente. Movidos por críticas ao papel do Estado na educação, o sistema educacional e escolar tem se tornando um importante e frutífero nicho mercadológico e ideológico para diferentes setores conservadores da sociedade. Ela observa as influências das organizações empresariais nas políticas educacionais brasileira e seu entrelaçamento político. A autora aponta que:

Paralelamente, a educação pública passou a sofrer também um processo silencioso - e às vezes não tão silencioso - de intervenção do setor privado nas decisões político-educacionais dos diferentes entes governamentais. Travestida de corresponsabilidade social, essa intervenção conta com mecanismos de cooptação da mídia e é amplamente amparado por ela (MARTINS, 2018, p. 4-20).

Ao examinar o movimento Todos Pela Educação (TPE), a pesquisadora apresenta a trajetória das empresas nas políticas educacionais. Martins mostra que a reorganização política dos anos de 1990, as reformas neoliberais e a lógica da modernização e das novas formas de fazer políticas públicas, na gestão Fernando Henrique Cardoso (1995-2002), marca o surgimento da incidência empresarial na educação pública. Aponta que, na contemporaneidade, a educação é recolocada como dimensão essencial para o desenvolvimento nacional e para a política econômica no que tange à competividade internacional: "Na descentralização para o mercado, o compartilhamento das responsabilidades por formular e implementar políticas implica uma articulação entre Estado, setores privados e organizações não governamentais" (MARTINS, 2016, p. 12).

Erika Martins (2016) indaga como o Todos Pela Educação se apresenta como um movimento complexo e contraditório nos âmbitos políticos, sociais, educacionais e culturais, alcançando o patamar de especialista em educação ao agenciar junto ao governo uma ampla reforma no sistema educacional. A pesquisadora busca entender como o projeto pretende reorganizar as políticas educacionais promovendo nova dinâmica da esfera pública.

Enfim, norteia toda essa pesquisa a tentativa de compreensão da construção de um projeto hegemônico, no qual a educação pública ocupa um lugar estratégico. Nesse processo, a investigação procura analisar como as propostas educacionais promovidas por frações da classe burguesa tornam-se parte de um projeto para toda a nação no 
século XXI, segundo o próprio TPE (Todos Pela Educação) (MARTINS, 2016, p.15).

A autora aponta que, no Brasil, alguns empresários se destacam por atuarem em esferas que extrapolam a econômica. Dessa forma, afirma que representantes de algumas frações da burguesia nacional não podem ser vistos apenas como "empresários desprovidos de interesses de classe" e, sim, como pessoas capazes de mobilizar redes, parceiros, lideranças políticas e econômicas, devido ao seu poder de influência (MARTINS, 2016). Esses atores, num pacto pela educação, tentam organizar a sociedade, agem como uma classe dirigente, pretendendo impor um direcionamento intelectual e moral a partir de sua visão do mundo.

Conforme recupera Martins, a entrada e incidência de empresários na educação pública começa um pouco antes do governo Fernando Henrique Cardoso (1995-2002). Houve iniciativas para estabelecer alianças entre o poder público e privado. O Jornal Gazeta Mercantil e o Instituto Herbert Levy (IHL) elaboraram um documento com o título "Educação fundamental \& competitividade empresarial: uma proposta para a ação do governo”. Em 1993, o Ministério da Ciência e Tecnologia, junto a Organização Mundial do Trabalho e uma associação de empresários, promoveu discussões sobre o sistema público de ensino (FOGAÇA, SHIROMA, GARCIA \& CAMPOS apud MARTINS, 2011, p. 230).

Surgiram outras iniciativas ao longo dos anos de 1990, tendo como bandeira melhorar a qualidade da educação pública por meio de alianças entre empresários, poder público e organizações internacionais, como o Banco Interamericano de Desenvolvimento (BID) e o Banco Mundial. Entretanto, esses foram empreendimentos regionais e pontuais que não se sustentaram por muito tempo. Além disso, um projeto de nação, como o TPE propõe, não estava no escopo dessas iniciativas.

O movimento Todos Pela Educação, que, no início, chamava-se Compromisso Todos Pela Educação, foi lançado em setembro de 2006 com a presença de empresários, poder público e representantes da sociedade civil organizada pela melhoria da educação, como a Undime (União dos Dirigentes Municipais de Educação). O Ministro da Educação à época, Fernando Haddad (2005-2012) também esteve presente confirmando a ligação entre o Poder Executivo e o setor privado:

(...) ao anunciar em entrevista veiculada em cadeia nacional que as metas lançadas deveriam ser assumidas pela sociedade (Jornal Nacional, 2006). Também participaram atores que trabalhavam na Rede 
globo, representantes de pais de alunos, além de estudantes do Ensino Básico" (MARTINS, 2016, p.43).

O lançamento do TPE, e os eventos e personalidades que giraram em torno dele, foi considerado um marco importante que favoreceu a entrada sistemática do meio empresarial na educação pública com o apoio e fortalecimento do poder público. Já em 2017, quando o Governo Federal lançava o Plano de Desenvolvimento da Educação (PDE), foi também consolidado, por meio do Decreto 6.094/07, o Plano de Metas do TPE, firmando de vez o alinhamento entre o Poder Executivo e o Todos Pela Educação.

Da sua fundação até 2010, o TPE se preocupou com sua autopromoção, divulgação de seus planos e metas e incorporar outros segmentos da sociedade. Sofreu muitas críticas, que diziam que seu propósito estava sendo apenas apresentar suas metas sem enunciar como fariam para alcançá-las. A partir disso, em 2010, a organização lançou um programa de atuação, denominado de "As 5 Bandeiras". São elas:

1. Currículo: o país precisa ter um currículo nacional, com as expectativas de aprendizagem dos alunos por série/ciclo.

2. Valorização dos professores: o magistério deve ter uma formação adequada, com foco na aprendizagem dos alunos, além de contar com uma carreira mais atraente.

3. Fortalecimento do papel das avaliações: as provas aplicadas para medir a qualidade da educação devem orientar as políticas públicas e as práticas pedagógicas. Por isso, é necessário que elas forneçam informações aos professores e gestores sobre o que os alunos aprenderam e deixaram de aprender.

4. Responsabilização dos gestores: os gestores brasileiros devem ser apoiados, mas também responsabilizados pelo desempenho dos alunos.

5. Melhora das condições para aprendizagem: o país deve ampliar a exposição dos alunos à aprendizagem por meio do cumprimento das quatro horas diárias obrigatórias e da ampliação do turno de ensino, com utilização de contraturno para reforço escolar e recuperação (MARTINS, 2016, p. 44).

Em documento oficial, o TPE apresenta elementos para a compreensão do programa em 2012, em relatório com os resultados obtidos. Acredito que não cabe aqui o detalhamento das ações e efetivações ou não das "bandeiras", mas vale destacar o posicionamento do TPE a respeito delas e o que a organização pretende. Outro ponto importante é a filiação do TPE com outras instituições internacionais. A esse respeito, escreve Erika Moreira Martins:

É interessante destacar que o estabelecimento de "bandeiras' foi fruto de troca de experiências entre o TPE e o grupo Mexicanos Primero, fato que demonstra a articulação entre grupos que procuram atuar na educação pública da América Latina, como se pode verificar no 
depoimento da diretora executiva do Todos Pela Educação (MARTINS, 2016, p. 45).

A Rede Latino-americana de Organização da Sociedade Civil para a Educação (Reduca) é uma organização fundada em 2011 que junta grupos da América Latina, incluindo o TPE e o Mexicanos Primero. São 15 países e organizações empresariais participantes da Rede. São eles: Argentina - Proyecto Educar 2050; Brasil - Todos Pela Educação; Colômbia - Empresarios por la Educación; Equador - Grupo Faro; El Salvador - Fundación Empresarial para el Desenrrollo Educativo (Fepade); Guatemala Empresarios por la Educación; Honduras - Fundación para la Educación Ernesto Maduro Andreu (Farema); México - Mexicanos Primero; Nicarágua - foro educativo nicaraguense "Eduquemos"; Panamá - Unidos por la Educación; Paraguai - Juntos por la Educación; República Dominicana - Acción por la Educación (Educa); UruguaiReachingu. ${ }^{10}$

Interessante perceber que a inclinação de grandes organizações e empresários para a educação pública não acontece somente no Brasil. Há uma rede internacional atuando nesses países com o propósito de elevar a qualidade da educação pública em cada um deles. Algumas perguntas não querem calar e, na realidade, continuam sendo basicamente as mesmas do início desta pesquisa: qual o verdadeiro interesse de empresas e empresários milionários na educação escolar da população pobre e periférica da América Latina? Qual o papel do Estado frente essas organizações?

Além dessas organizações que são formadas, pensadas e administradas por grandes empresários de diferentes setores, ONGs de grande e médio portes estão a elas ligadas. Mais de 40 instituições que trabalham com projetos voltados para a educação no Brasil, por exemplo, estão associadas ao Todos Pela Educação. Algumas delas, as maiores, geralmente pertencentes aos setores da indústria e bancário, têm seus diretores transitando ora na administração, ora na diretoria do TPE. Especialistas em educação e acadêmicos também se afiliam ao Todos Pela Educação e são chamados para proporem projetos, consultorias, programas nas mídias sociais. Érica Moreira Martins, realizou um magnífico trabalho montando um mapa das instituições e pessoas ligadas ao TPE que reproduzo a seguir:

\footnotetext{
${ }^{10}$ Fonte: site Todos Pela Educação e Reduca: https://www.todospelaeducacao.org.br/pag/iniciativa-reduca; https://www.reduca-al.net/pt/.
} 


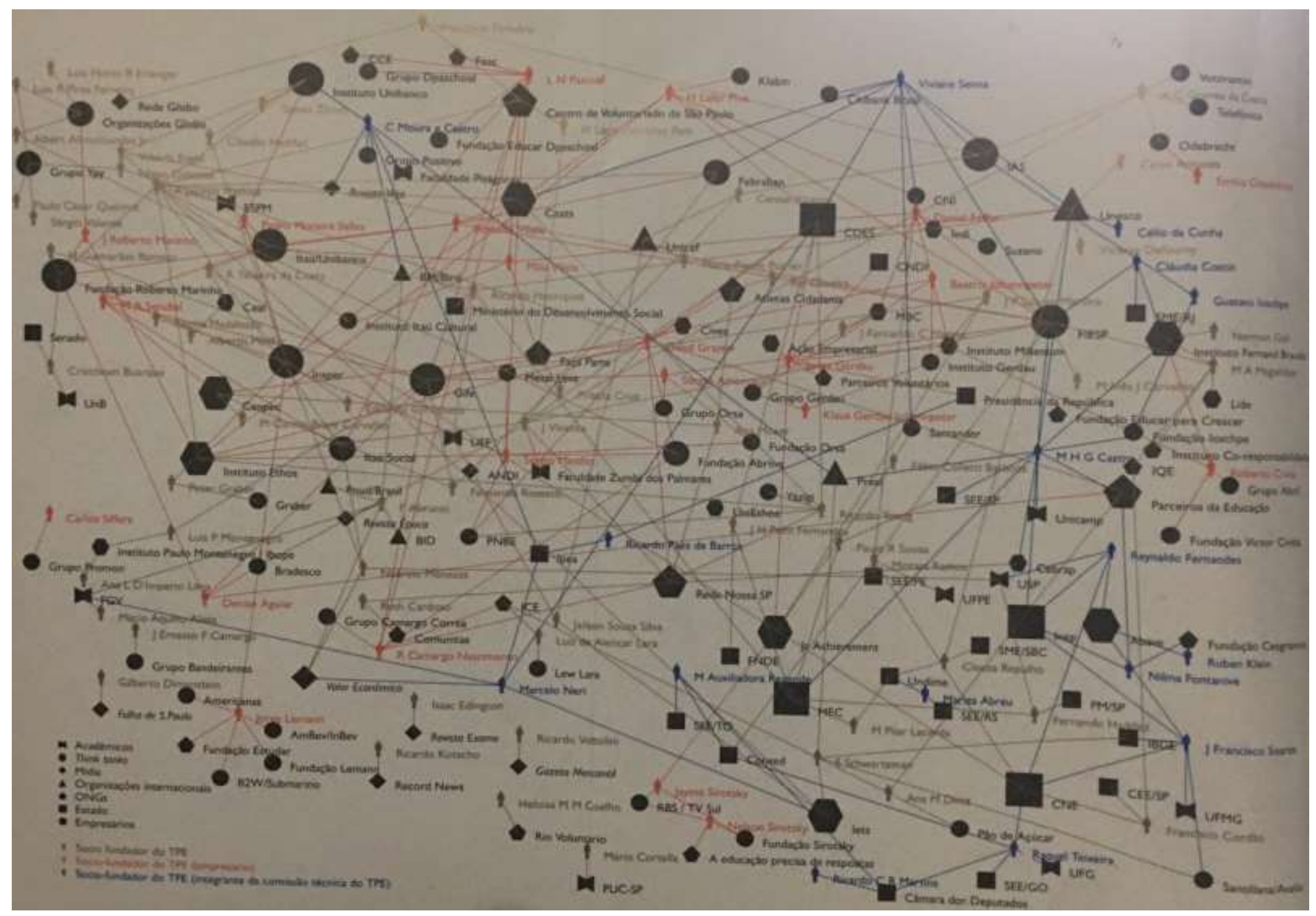

Mapa de instituições e atores da educação. Fonte: Martins, 2016. 
Destaco algumas das organizações e pessoas apresentadas neste mapa que, em sua legenda, têm as seguintes classificações: Acadêmicos, Think Tanks, Mídia, Organizações Internacionais, ONGs, Estado e Empresários. São eles: Grupo DPaschoal, Fundação Lemann, Votorantim, Unesco, Instituto Gerdau, Instituto Milenium, Instituto Unibanco, Citibank Brasil, Organizações Globo, Fundação Orsa, Telefônica, Odebrecht, Fundação Cesgranrio, Pão de Açúcar, Unicef, Fundação Abrink, Cebrap, Unicamp, USP, Grupo Abril, Parceiros da Educação, Ação Educativa, Cenpec, Atletas Cidadania, UFG, Faculdade Zumbi dos Palmares, Revista Época, Instituto Ethos, Valor Econômico, Gazeta Mercantil, Grupo Camargo Correia, Comunitas, Instituto Itaú Cultural, Jorge Lemann, Viviane Senna, Ruben Klein, Ricardo Paes de Barros, Cláudia Costin, Célio da Cunha, Lafer Piva, Presidência da República, IBGE, Ministério do Desenvolvimento Social, Ibope, Câmara dos Deputados, entre outros.

Acerca das ONGs, sua vinculação ao TPE, em grande parte das vezes, consiste na execução dos projetos das grandes instituições, por meio de um contrato chamado de parceria. Elas começaram a atuar no mesmo momento em que as grandes organizações. Veremos um breve histórico da formação dessas ONGs e suas inclinações. 


\subsection{Saberes Técnico-Burocráticos: o avanço e as contradições das ONGs no Brasil}

A década de 1990 foi realmente muito profícua para o surgimento e aumento expressivo das instituições não governamentais no Brasil. A abertura econômica promovida pelo governo Fernando Henrique Cardoso, de diferentes formas, propiciou a abertura e espraiamento dessas organizações, com diferentes objetivos e temáticas, atuando, na maioria das vezes, no campo social, mais especificamente nas favelas, comunidades e periferias do país.

Existem muitos trabalhos acadêmicos dando conta dessa temática, porém, um deles analisa a atuação das ONGs de uma forma que particularmente interessa aqui, qual seja: como "entes técnico-burocráticos". Vejamos os argumentos da autora.

Em sua tese de doutorado, defendida em 2010, Anna Catarina Morawska Vianna se propõe ao desafio de "etnografar emaranhados transnacionais de combate à pobreza"

A análise desses "emaranhados institucionais" é feita a partir de uma etnografia da parceria entre quatro atores distintos: CAFOD (Catholic Agency for Overseas Developement - ONG internacional católica sediada em Brixton, Inglaterra, cujas as origens remontam os anos de 1960, financiadora de "projetos sociais" em países em desenvolvimento); Galpão dos Meninos e Meninas de Santo Amaro; Grupo Comunidade Assumindo suas Crianças; e o Grupo Sobe e Desce de Olinda (três pequenas organizações comunitárias locais - grassroots - que realizam trabalhos pontuais com crianças e adolescentes em bairros periféricos de Recife e áreas da região central de Olinda). Esta parceria, batizada pelos próprios atores como Projeto Tarrafa, em homenagem a pequena rede usada pelos pescadores de Pernambuco, existe desde final dos anos 1980. "Todos os quatro constituíram-se, portanto", afirma Vianna (2010), "na relação com outros atores em circuitos internacionalizados", isto é, "canais institucionais que conectam organizações atuantes na área social" ao redor do mundo.

A fim de melhor analisar seus sujeitos etnográficos, a autora recupera a discussão sobre o "fenômeno da multiplicação de ONGs pelo mundo" desde os anos de 1970 e 1980, realizada tanto por estudiosos posicionados no âmbito do Banco Mundial em Washington, por exemplo, quanto por uma das pioneiras a realizar pesquisas sobre a presença das ONGs no Brasil, Leilah Landim (1993), do Instituto de Estudos da Religião (ISER), no Rio de Janeiro.

Acerca do fenômeno das ONGs no Brasil, Vianna (2010) destaca os seguintes 
elementos: a) o boom das associações civis nas últimas duas décadas; b) o direcionamento político de suas atividades e um esforço para se distinguirem de organizações assistencialistas; e c) o modelo de projeto que implica em parcerias com entidades financiadoras não governamentais internacionais, base de constituição de ONGs brasileiras nos anos 1980 e 1990.

Vianna realiza um interessante resgate histórico da mobilização de saberes técnico-burocráticos para o estabelecimento de parcerias de cooperação internacional, apontando continuidades desde a época colonial, particularmente acerca da atuação do Reino Unido. Acompanhar os argumentos da autora permite situar esta pesquisa em um processo mais abrangente, tanto do ponto de vista histórico quanto geopolítico.

Para corroborar um dos aspectos da contribuição desta ferramenta, qual seja, a de que a mobilização de saberes técnico-burocráticos para o estabelecimento de parcerias de cooperação internacional de combate à pobreza é uma exigência desde a época colonial, Vianna lança mão do livro intitulado People and the State: An Anthropology of Planned Development, em que o antropólogo Alexander Robertson (1984) relata uma sucessão de leis no Reino Unido, explicitamente voltadas a projetos de desenvolvimento, partindo da Colonial Developement Act (Lei de Desenvolvimento Colonial) de 1929. Em 1940, em consequência das rebeliões nas colônias britânicas das Índias Ocidentais que se seguiram à Depressão dos anos 30", uma nova lei foi introduzida: a Colonial Developement and Welfare Act (Lei de Bem-estar e Desenvolvimento Colonial), revisada cinco anos depois, em 1945. Inicialmente, havia o objetivo restrito de combater o desemprego e estimular o comércio e indústria no Reino Unido, mas, a partir de 1940, a legislação estende-se para incluir o bem-estar dos sujeitos nas colônias nos projetos de desenvolvimento.

Para ter acesso aos recursos de investimento, a lei de 1929 exigia que os funcionários coloniais tinham que enviar "propostas" ("esquemas de desenvolvimento") que "assemelhavam-se a listas de compras". Posteriormente, porém, a legislação britânica passa a exigir alguma "técnica de planejamento e gestão" das solicitações enviadas pelos funcionários coloniais.

Após a Segunda Guerra Mundial, dois conjuntos de saberes e práticas passam a regular os projetos de desenvolvimento. As técnicas de "administração científica" que visavam a "aumentar a eficiência" do setor produtivo, por um lado, e, por outro. os saberes a respeito de como "solucionar problemas de "regiões subdesenvolvidas", provenientes de uma literatura da "administração pública" produzida por instituições como a Organização Internacional do Trabalho e por funcionários coloniais. 
A partir desse período, a "massa de agências de cooperação internacional" e bilateral entre dois países que surge é chamada, por Arturo Escobar (1995), de aparato mundial de desenvolvimento. A criação da ONU e de seus organismos multilaterais dá início a esse movimento, que é acompanhado pela criação de outros órgãos governamentais de cooperação internacional e outras organizações multilaterais não ligados à ONU necessariamente. Um exemplo é o Grupo de Assistência ao Desenvolvimento (DAC), criado em 1960 no âmbito da Organização para Cooperação Econômica, por sua vez, criada em 1948 e formada pelos países receptores do Plano Marshall. Outro exemplo é a criação, pelo governo britânico, em 1961, do Departamento para a Cooperação Técnica, que foi o germe d Departamento para Desenvolvimento Internacional (DFID), órgão governamental do Reino Unido atualmente responsável pela cooperação internacional e que é parceiro da CAFOD.

Embora reconheça que o foco de Robertson era o planejamento estatal no século XX, Vianna estende e reformula seu argumento nos seguintes termos: saberes técnicoburocráticos de planejamento, monitoramento e avaliação de projetos de desenvolvimento, bem como a gestão e prestação de contas de recursos repassados, eram cada vez mais mobilizados por organizações governamentais e não-governamentais que formavam emaranhados institucionais de longo alcance com vista a promoção do "desenvolvimento".

Seguindo a caracterização feita por Nikolas Rose (1999), Vianna volta-se para a análise dos saberes e práticas da nova gestão pública que hoje marca o tipo de padrão das relações de cooperação internacional, cujo suporte da governabilidade passa a ser financeiro. Esse novo regime de regulação se dá com a disseminação do padrão de descentralização orçamentária, em que cada aparelho , governamental governamental, e em seu interior, departamento e secretaria, assim como cada organização nãogovernamental que com ele mantém relações, torna-se um nódulo orçamentário responsável pela boa implementação dos recursos que lhes são confiados, cujos objetivos, sejam eles quais forem, devem sermensurados por indicadores quantificáveis, dispostos pelos executores do projeto.

Segundo Vianna (2010), a noção de capacity-building (capacitação) disseminada por tal modelo é explicitada na Declaração de Paris sobre Eficácia e Ajuda ao Desenvolvimento (1995), a qual é reflexo de um processo lento que vinha ocorrendo nas relações de parceria nos anos de 1980 e 1990: "a capacidade de planificar, administrar, implementar e responder pelos resultados de políticas e programas é um elemento 
essencial para a realização dos objetivos de desenvolvimento, desde a análise e do diálogo até à implementação, monitoração e avaliação".

O novo modelo de gestão pública manteve-se intacto mesmo após 1997, com a saída do governo conservador no Reino Unido. Tais reformas atingiram tanto o departamento responsável pela cooperação internacional quanto quem com ele mantinha relações, como a CAFOD.

Foram três as transformações importantes que as reformas que passaram a ser implementadas a partir daí. Criado em 1997, o Departamento para Desenvolvimento Internacional (DFID) passa a medir o sucesso de suas atividades segundo indicadores específicos e planejados tendo as Metas do Milênio como horizonte mais amplo. A segunda mudança é que o DFID não mais apoiaria projetos isolados, mas "apenas programas mais amplos, considerados estratégicos". A terceira transformação é a intensificação da relação com organizações não-governamentais internacionais de origem britânica. A agenda de modernização do setor público inclui a noção de "governocongregado" (joined-up government): trabalho conjunto do governo central com os governos locais, e das agências públicas com as do setor privado e com o setor voluntário (voluntary sector), que inclui as instituições de caridade (charities), de atuação nacional e internacional.

Em 2000, o DFID firmou o Acordo de Programas em Parceria (PPA, sigla em inglês), que definiu novos termos para suas políticas: financiamento de programas maiores, elaboração de Country Strategy Papers, planejamento estratégico, objetivos de desenvolvimento claros, implantação de sistemas de gestão e sistemas de monitoramento. Essa reestruturação institucional das ONGs internacionais de combate à pobreza também "era repassado aos seus parceiros ao redor do mundo". ONGs internacionais que quisessem acessar recursos de agências bilaterais ou multilaterais de cooperação internacional através de acordos de parceria deveriam estar "capacitadas" a se "responsabilizar" pelos investimentos alocados em projetos de desenvolvimento. Aos parceiros dessas ONGs no "sul": o mesmo requisito.

Para fora do Reino Unido, os enormes volumes de recursos privados comparativamente aos recursos públicos, embora crescentes, provenientes de agências bilaterais e multilaterais, entre 1975 e 1985, denotavam a capilaridade das ONGs internacionais com seus parceiros dentro e fora da Europa, bem como "um adensamento dos emaranhados que tendia a uma aglomeração de organizações não-governamentais relacionadas entre si”, fator que também estimulava a adoção de “'boas práticas” em 
sistemas de planejamento, gestão, monitoramento e avaliação". Parte desse adensamento foi resultado da antiguidade da atuação de ONGs focadas em ajuda humanitária, como Save the Children (1919), Oxfam (1942), Catholic Relief Services (1943). Os "desastres naturais comunicados pela mídia" também tiveram seu papel nessa expansão. A partir dos anos de 1970 e 1980, apesar da origem distinta dessas organizações, elas multiplicam-se, conectam-se, tornam-se menos assistencialistas e passam a fortalecerem sua estrutura interna, conforme descrito por Cernea (1988). O interesse do Banco Mundial em estabelecer interlocuções com as ONGs internacionais nos anos de 1980, o aumento do fluxo de recursos e a expansão do mercado de trabalho na área de desenvolvimento nos anos 1990 são outros fatores explicativos desse adensamento de emaranhados institucionais de longo alcance, ou burocracias nacionais e internacionais ramificadas que se constituem a partir de relação mútua de organizações (entes técnico-burocráticos), através de uma massa amorfa de esquemas e projetos em expansão.

Todo este movimento de expansão e influências mútuas pode ser atestado pelo caso da CAFOD, estudada por Vianna (2010), que parte, em 1977, de uma estrutura de uma dezena de funcionários e chega a 2008 com uma estrutura técnica, sofisticada e com quatrocentos profissionais.

Nesses complexos processos Estado ainda mantém a função pública de destinatário das demandas popular, contudo, o que antes era tutelado exclusivamente pelo Estado, passou a ser compartilhado com instituições da sociedade civil, as ONGs. Com a desestabilização dos Estados e perda de parte da sua autonomia frente ao mercado, as ONGs ganharam legitimação para atuarem em diferentes áreas, como a da educação, meio ambiente, e outras questões referentes às situações de pobreza. Nesse cenário, as ONGs aparecem como um amparo para o Estado e mantém relações diretamente com ele (RODRIGUES, 2013).

Voltando o olhar ao cenário brasileiro, um ponto de vista importante é a análise de Maria Célia Paoli.

Paoli (2003) destaca alguns pontos importantes sobre a ambiguidade política da responsabilidade empresarial sobre a questão social. A chamada "fillantropia social cidadã" substitui o setor público como ponto de referência para reduzir as desigualdades, de modo que as decisões poderiam ter uma participação ampliada, pelo setor privado. As práticas de deliberação participativa no Brasil desde o princípio estiveram ligadas a atuação dos "novos movimentos sociais" da década de 1970-1980, movimentos que 
lutavam por participação popular e bandeiras plurais, e a substituição do setor público pelo setor privado dificulta a inclusão desses setores nos espaços de deliberação.

A autora argumenta que foram esses novos movimentos sociais que incluíram a palavra cidadania no vocabulário da sociedade, a partir da busca por participação nas decisões políticas, e modificaram a forma de exercício de poder, configurando um “modelo participativo" de negociação e deliberação pública e política.

A autonomia pública desses novos movimentos sociais ocasionou o surgimento de organizações públicas não estatais, modo como Paoli caracteriza as ONGs, nas quais se corporificariam uma noção de sociedade civil e um protagonismo popular.

O surgimento das ONGs, denominado pela autora de segundo movimento, coincidiu com o momento em que o Estado diminuía sua responsabilidade social. A partir daí, as ONGs passam a cumprir a responsabilidade com as políticas sociais que o governo abandonou, buscando recuperar a cidadania e combater a pobreza por diversos caminhos. Existem também as ONGs que, através das políticas sociais, ajudam na manutenção do sistema político e neoliberal, articulando responsabilidade social com a introdução da lógica dominante.

As organizações empresariais de investimento social institucionalizam-se como terceiro setor para, segundo Paoli, falar "veladamente sobre a própria modificação da ideia de troca mercantil que vem incluída em sua imagem virtuosa, através da ampliação de sua presença no social (...) o aumento do que chamei (...) de "poder social'”. Os serviços prestados por essas empresas retornam ao espaço de rentabilidade mercantil e agregam valores a seus produtos.

Paoli defende que os serviços sociais oferecidos mudam a visão sobre os produtos que a empresa produz, criando uma boa imagem deles, que não se refere às suas qualidades em si.

Esse caráter de empresa cidadã faz com que elas assumam uma feição ambígua, de empresa mercantil e não mercantil. Nas relações de trabalho, isso acabaria solucionando problemas internos quando a ação de solidariedade é dirigida aos trabalhadores da própria empresa, ajudando em negociações com os mesmos. Ao mesmo tempo em que a empresa pode estar realizando um bom trabalho social (ou não) com essa comunidade de trabalhadores, está exercendo uma política de empresa que ajuda a diminuir incertezas e o vínculo fundamental do contrato que define a relação de trabalhador assalariado e empregador. 
A filantropia empresarial tem sido utilizada como modelo para desmoralizar a capacidade do Estado em promover políticas públicas, tentando convencer a opinião pública de que a substituição das políticas de Estado pelas políticas privadas tem tido melhor serventia à população, o que ajuda a diminuir a credibilidade do Estado. Paoli (2003) argumenta que a responsabilização privada do social é despolitizada, pois parte em princípio da desqualificação do poder público e, portanto, desconhece a possibilidade aberta pelo conflito interno, no terreno das próprias políticas públicas, de criar compromisso e qualidade frente aos cidadãos

A noção e a implementação de um Estado mínimo, que vem suprimindo as políticas sociais, cria uma imagem negativa em relação ao servidor público, que é colocado como "preguiçoso", que não cumpre o seu trabalho. Essa imagem difundida é também responsável pela crescente responsabilização privada do social e pela descrença na renovação de um setor público comprometido.

Segundo Paoli (2003), a reestruturação produtiva das empresas reduziu a força de trabalho, gerando a crise do trabalho regulado e, consequentemente, a crise do sindicalismo. Isso fez com que os sindicatos dos trabalhadores buscassem novas formas de integração no mercado para os desempregados de suas categorias, criando assim experiências de solidariedade que se diferenciam da filantropia empresarial, pois não buscam resolver momentaneamente as situações de vulnerabilidade social, mas lutam pelos direitos dos trabalhadores e pela promoção do emprego. A autora cita como exemplo a Força Sindical e a CUT, dando mais ênfase à experiência desta última.

Paoli (2003) realiza uma reflexão sobre a concepção dos sindicatos quando trabalham com política públicas de inclusão e realocação do trabalhador, sobre o papel do Estado, pois, a partir destas ações, também estariam assumindo o papel que é do Estado na resolução do desemprego. Mas a diferença, segundo a autora, entre o papel das instituições sindicais e das empresas sociais nas ações de solidariedade, está na presença ou ausência de instituições contra hegemônicas

A ação do sindicato pode ser constituída como uma esfera pública não estatal, pois qualquer ação cujas práticas se articulam com o contexto político da sociedade e do Estado, e gere inovação de ideias e de experiências de participação democrática produz um espaço público. As empresas que exercem a filantropia falham por não incorporar o debate sobre as decisões governamentais, e por dialogar com o Estado somente para exercer pressões por seus interesses econômicos, suas demandas por serem intermediários dos recursos públicos. Erram também ao transformar os direitos dos cidadãos em 
caridades, ou seja, transformá-los em receptores de favores e generosidades daquilo que deveria ser, por obrigação política, papel do Estado, do qual eles recebem benefícios financeiros para desenvolver.

A noção de direito defendida por Paoli (2003) cria comunidades políticas falantes e reflexivas sobre si mesmas e não submissas à aleatoriedade das necessidades e conveniências que vêm de fora. Para a autora, somente essa sociedade reflexiva e atuante pode mudar a realidade atual através da participação e da busca por direitos para construir novas formas de resistência e sociabilidade.

As experiências de filantropia empresarial destacadas pela autora são importantes diante da carência da sociedade brasileira, mas teriam maior importância se, dentro dessas ações sociais, fossem também politicamente relevantes, reconhecendo o espaço público como construtor de cidadania no contexto em que vivemos de desregulamentação estatal.

Essas filantropias empresariais fortalecem a classe dominante ao se distanciarem da noção de cidadania e promovem a integração dos excluídos à sociedade sem direitos, construindo, por mais solidárias que possam ser, ações sociais que mantêm as estruturas de poder, por preservarem as hierarquias desiguais da sociedade, descapacitando os cidadãos, tornando-os dependentes de caridade do setor privado para inclusão social. 


\subsection{O Campo: burocratas de rua? O que dizem e o que pensam}

Eu, sinceramente penso que as parcerias que a prefeitura faz são super bem-vindas. Aqui, a prefeitura tem dinheiro, mas não sabe investir em nada. Não dá nenhum curso para nós, nem formação. Nos outros municípios tem. Eu trabalho em outros e sempre tem formação, então quando vem essas formações pra gente e de graça, aproveitamos mesmo (Laudelina de Campos).

Eu não gosto muito, tudo é muito burocrático. Já temos coisas demais para fazer, e esses cursos só demandam da gente e no fundo não servem para nada. Não dá para entender nada, porque o que a gente precisa de verdade, não temos e não adianta falar com a nossa supervisora [supervisora de ensino] ela também não tem poder para nada. Tudo isso que vocês querem que a gente faça, não vamos fazer porque não dá. Não cabe aqui no município, só algumas coisas (Anastácia).

Posso falar a verdade, professora, agora que você já conhece a gente, eu posso ser sincera? Quando a parceria chegou aqui nós nem fomos avisadas do que se tratava, disseram que era um curso do [Instituto Cameleão] e fomos. Fomos obrigadas, para falar a verdade. Essa empresa só quer fazer o nome em cima da gente. Não dá emprego para ninguém, sujou nosso rio e até hoje não limparam, passam pela gente com o queixo erguido e depois vem querer agradar a gente com projetinhos para educação. Essa história é antiga, professora. Tudo bem, fizemos o curso obrigadas, mas o que eu aprendi, vou trazer para minha prática só o que me interessa, o que eu acho legal e importante (Aqualtune).

Gente, espera, não é bem assim! A gente aproveita algumas coisas sim! Não dá para jogar tudo fora, tem coisas, temas legais e a gente só se encontra de verdade nesses momentos de formação. Não tô discordando do pensamento de vocês, mas não é tudo ruim (Laudelina de Campos).

Tá bom, mas sabemos que a empresa, sempre que quer alguma coisa, vem com esses cursos, projetos e sabemos bem que é só pra agradar. Se quer agradar, então, dá emprego para os nossos jovens! Sinceramente, é isso, e não é só com esse curso dessa 
parceria, professora, são com todos dessas parcerias que a prefeitura faz e traz para a gente. Só ponho na minha prática, na minha escola, o que acho importante (Aqualtune).

Ou então, coloca uma internet boa na cidade, ou, pelo menos, nas escolas, mas nem isso. E tudo deles é em plataforma digital, tudo, e já foi falado várias vezes que aqui em Laranjeiras o que menos temos é internet boa. Não funciona nem na prefeitura. Como eles pedem para fazermos acompanhamento das aprendizagens usando essas plataformas? É cada coisa... Não dá pra fazer quase nada que nos foi pedido e que aprendemos no curso e, vou dizer, o Secretário sabe disso, mas também, coitado, não pode opinar muito (Tereza de Benguela).

Nós que fazemos tudo girar por aqui. Ela [a empresa] deveria dar é dinheiro pra gente. Os projetos só funcionam porque, mesmo com tudo, a gente não deixa a bola cair. Vamos até o fim e fazemos bem feito (Maria Firmina).

Os diálogos acima aconteceram durante uma conversa que tive com as gestoras de Laranjeiras no momento do meu trabalho de campo. Já havia passado alguns meses que o ciclo formativo do Instituto Cameleão havia se encerrado. Convidei algumas delas para essa conversa. Expliquei que se tratava da minha pesquisa de doutorado e nada tinha a ver com o projeto/parceria. Disse, ainda, que elas poderiam ficar à vontade para falar, pois aquele momento era só nosso e eu não usaria o nome delas em nenhuma parte do trabalho. Naquela conversa, ao tratar do tema das parcerias, eu fiz apenas duas perguntas: o que vocês pensam sobre parcerias público-privadas na educação de Laranjeiras? Como é para vocês?

A conversa durou cerca de duas horas, num estilo bem livre. Houve concordâncias e discordâncias sobre a atuação das parcerias na educação do município, em especial àquela em vigência.

Essa parceria inicia-se com uma pactuação. Os Secretários dos municípios são convidados para um encontro financiado pela própria empresa. Nesse encontro, geralmente de três dias, as Secretárias e os Secretários conhecem o Programa e, ao aceitarem, fazem uma pactuação, ou seja, um compromisso de levar e fazer funcionar a parceria em seus municípios. Elas e eles trazem consigo um técnico ou uma técnica da Secretaria que recebe o codinome de Técnico Mobilizador. É esta pessoa quem vai mobilizar todo o pessoal da Secretaria, das escolas e do município para a parceria. Ela 
participa de todo o processo de pactuação e escolhe, junto com a Secretária ou Secretário, a temática que será trabalhada: Educação Inclusiva, Espaço como Ambiente de Aprendizagem, Avaliação Participativa para a Melhoria da Aprendizagem: Aplicação dos Indicadores de Qualidade na Educação. A escolha geralmente é feita com base no IDEB do município ou pelas necessidades formativas sugeridas pelas gestoras escolares e educacionais.

A avaliação participativa com a aplicação dos Indiques ${ }^{11}$ foi a temática escolhida por Laranjeiras. Isso se deveu ao foco do município naquele momento nos conselhos escolares: a cidade estava formando os seus conselhos naquele ano. A Meta 19 do Plano Nacional de Educação prevê (aponta para a obrigatoriedade) que os municípios tenham conselhos escolares. Sem eles, parte da verba para a educação vinda do Governo Federal é retida. No Plano Municipal de Educação de Laranjeiras, a Meta 19 foi mantida, por isso a necessidade de formar e fortalecer os conselhos escolares na cidade.

Os Indicadores da Qualidade da Educação são uma proposta metodológica de autoavaliação participativa que pretende envolver os diferentes atores da escola e da comunidade escolar. Essa metodologia foi desenvolvida por um conjunto de pessoas e instituições ligadas à educação. A proposta envolve avaliação, diagnóstico e plano de ação para dar conta das questões que não estão indo bem nas escolas. Trata-se de um processo avaliativo que analisa a escola e a gestão educacional (Secretaria da Educação), tendo três indicadores: Educação Infantil, Ensino Fundamental e Relações Raciais na Escola. Este último pode ser trabalhado juntamente com os outros dois. Veremos adiante como este processo avaliativo foi aplicado nas escolas do município.

Toda comunidade educacional e escolar de Laranjeiras teve que se reorganizar obrigatoriamente em torno dessa parceria, causando desconfortos e distanciamento das gestoras educacional e escolar em relação à proposta. Este distanciamento permeou vários pontos: não houve uma consulta com a rede de ensino sobre a parceria e como ela se daria antes da sua realização. As condições objetivas do município não comportavam o tipo de proposta oferecida, já que a parceria exigia o uso das Tecnologias de Informação e Comunicação (TICs), cujo acesso em Laranjeiras, como já vimos fartamente, é precário: não há internet na maioria das escolas e o sinal de telefonia não chega a muitas casas.

A questão que se coloca aqui é justamente avaliar o que uma política pública educacional, aparentemente homogeneizante e promovida por uma parceria público-

\footnotetext{
${ }^{11}$ Indiques é o termo utilizado para se referir aos Indicadores da Qualidade na Educação.
} 
privada que parece não levar em consideração as questões sociais, raciais, culturais e históricas do município, provoca no cotidiano educacional, na microesfera escolar. 


\subsection{A Parceria e suas Múltiplas Dimensões}

A gestão municipal (Secretarias de Educação), a gestão escolar (diretoras e coordenadoras pedagógicas) e a mobilização social em prol da educação são os focos desta parceria que acompanhei, no município de Laranjeiras.

A estrutura de operação acontece da seguinte forma: a coordenação geral é do Instituto que propôs a parceria, a execução local fica por conta das consultoras contratadas pela ONG responsável e por uma figura chamada de mobilizador. Este mobilizador é um funcionário ou funcionária que voluntariamente acompanha o programa. A função desta figura é mobilizar a população local para a parceria, por exemplo, ajudando as Secretarias Municipais de Educação a convidarem a população e as autoridades locais para os dias de encontro, organizando os materiais para as formações, preparando os lanches. Geralmente essa figura é moradora da cidade que vai receber o programa e é conhecida por muitas pessoas. Também é a pessoa que reporta para o Instituto como está caminhando a parceria.

A consultoria/formação acontece em quatro ciclos presenciais. A consultora/formadora vai a campo e fica cerca de 3 a 4 dias trabalhando com as gestões e com a mobilização social. O acompanhamento das atividades é feito por meio de uma plataforma digital. Nessa frente, a questão do acesso não é um problema apenas em Laranjeiras. Em muitos municípios que aderem a essa parceria, o acesso às tecnologias digitais e a internet é limitado e precário ${ }^{12}$, e as e os gestores não têm nenhuma familiaridade com as Tecnologias de Comunicação e Informação (TICs). A questão do acesso digital não é levada em conta pela parceria e isso propicia um desânimo e um constrangimento entre as e os participantes.

Em cada ciclo, as gestoras têm obrigatoriamente de entregar um produto, como um portfólio das atividades para os gestores escolares, e um documento orientador para a gestão educacional. O produto da mobilização social também é um portfólio e tudo tem de ser feito na plataforma digital disponibilizada.

Outra parte é a mobilização das crianças e adolescentes estudantes por meio de um prêmio. É feita uma oficina em que os estudantes são estimulados a pensar nos problemas da escola e do entorno dela. Também são estimulados a criarem projetos que elas e eles mesmos possam realizar, com o apoio da comunidade e sem auxílio financeiro.

\footnotetext{
12 Essa constatação foi feita com base nos relatos de consultores/formadores que trabalham para parceria em outros municípios.
} 
Ao colocar em prática esses projetos, as e os estudantes concorrem a um prêmio. A premiação acontece em nível municipal e nacional. Essa é uma iniciativa que os municípios que pactuaram com a parceria têm de cumprir.

É importante salientar que quem faz a parceria funcionar são as gestoras escolares, funcionárias públicas do município, com a ajuda de uma consultora/formadora, profissional contratada pela Saúva, que sustenta metodologicamente a parceria, no intuito de realizar o trabalho de formação e acompanhamento do projeto. Nesta ocasião, estivemos todas em situação de "burocratas de rua", elas compulsoriamente, eu deliberadamente.

No capítulo anterior, relatei um pouco da minha vivência com essas gestoras, os percursos percorridos com elas, algumas narrativas, pensamento e falas. Meu interesse nesta tese é, justamente, analisar como essas profissionais da educação analisam e vivem o projeto dessa parceria. Lembro, ainda, que este é um estudo de caso, entretanto, essa experiência pode ser observada em outros município, com outras parcerias e projetos dessa rede empresarial.

O subtítulo anterior, "Burocratas de rua?", tem fundamento teórico e metodológico em bibliografias fincadas, principalmente, no campo das ciências políticas e administração pública. Algumas vozes apresentadas indicam para essa literatura, uma corrente analítica que se dedica a pesquisar a implementação das políticas públicas, com foco nos atores que a implementam e a influenciam: os burocratas do nível de rua.

Nas políticas públicas, segundo Gabriela Lotta (2012), um assunto ainda elementar, a burocracia, embora esse campo de pesquisa tenha crescido na última década, assim, como a própria área ainda é, por conta da fragmentação na sua organização e da própria temática. Comenta a autora:

Há também limitações nesse campo quando observamos o pequeno e recente espaço que a literatura de políticas públicas tem dado para ampliar as formas de análise das ações do Estado, incluindo novos atores e novos modelos analíticos. Os estudos sobre a interação entre atores estatais e privados no processo de políticas públicas têm sofrido reformulações na últimas décadas (LOTTA, 2012, p. 1).

Lotta (2012), ao falar sobre os burocratas em nível de rua, recorda a trajetória teórica e empírica da burocracia. A autora aponta que Max Weber foi um dos pioneiros a analisar a questão. Para ele, a burocracia estava ligada diretamente aos tipos de autoridade: a carismática e a tradicional. Com o avanço da indústria e com a 
Modernidade, houve uma mudança na forma de administração do Estado, surgindo uma nova forma de autoridade, constituída por uma racionalidade-legal:

Para o autor, essa autoridade constitui-se sobre a crença da legalidade de padrões de regras normativas e na manutenção de um sistema de burocracias baseado em leis e regras. A burocratização, portanto, é vista como consequência do desenvolvimento de uma economia complexa e do sistema político (LOTTA, 2012, p. 4).

A autora enuncia que, devido à modernização da ação e do papel do Estado, estudos mostraram que a dicotomia entre burocratas e políticos não era mais tão nítida e o modelo weberiano perdeu sentido, dando lugar a outras percepções de arranjos institucionais e novas divisões. Nesse momento, começam a surgir novas pesquisas e teorias acerca do papel dos burocratas e suas complexidades.

Lotta (2012) utiliza-se, então, de uma definição de burocratas em nível de rua, baseada em Michael Lipsky (1980), que foi o pioneiro em estudar esse eixo analítico: "Para o autor, os burocratas de rua são funcionários que trabalham diretamente no contato com os usuários dos serviços públicos, como, por exemplo, policiais, professores, profissionais de saúde, entre outro" (LOTTA, 2012, p. 5).

Esses profissionais sofrem uma dupla pressão ao exercer suas funções: se, por um lado, precisam garantir a efetividade das políticas, por outro, são demandados pelos usuários a garantir uma maior eficiência no acesso aos serviços públicos. São eles que, ao interagirem diretamente com a população no fazer das suas funções, podem garantir, ou não, o acesso pelo público aos direitos e benefícios governamentais. Há duas discussões correntes sobre o papel desses burocratas, uma diz respeito ao seu escopo de atuação e as atividades exercidas por esses trabalhadores, e:

A segunda razão é que os agentes de rua tem grande impacto na vida das pessoas, na medida em que vivenciam as comunidades onde atuam; recebem e transmitem as expectativas dos usuários sobre os serviços públicos; determinam a elegibilidade dos cidadãos para acessarem os benefícios ou receberem sanções; dominam a forma de tratamento dos cidadãos e medeiam aspectos da relação institucional dos cidadãos com o Estado. Tornam-se, portanto, o locus da ação pública, na medida em que são responsáveis pela mediação das relações cotidianas com o Estado e os cidadãos (LOTTA, 2012, p.7).

Outra questão levantada diz respeito à interação entre os agentes públicos implementadores, ou seja, os burocratas em nível de rua e a população que demanda os serviços. A autora aponta que os burocratas são a personificação do Estado e que, quando os cidadãos - que são munidos de personalidades, necessidades e expectativas e de 
diferentes experiências da vida - os encontram, estes se tornam apenas clientes indiferenciados que serão alojados em algum padrão.

Os clientes pressupõem que seus problemas e demandas são individuais e requerem um tratamento individualizado para suas questões. Entretanto, os burocratas de rua acolhem suas demandas como requerimentos agregados, unificados e categorizados dentro do escopo de atuação dos serviços públicos que estão aptos a fornecer (LOTTA, 2012).

As discussões sobre os burocratas de rua são complexas, visto que a implementação das políticas passa por eles, que são o "braço do Estado" na medida em que ocupam parte considerável da burocracia estatal. Portanto, o Estado dispõe de um volume grande de recursos para contratá-los e, tendo influência direta sobre as pessoas de baixa-renda, são eles os responsáveis por garantir a essas pessoas o acesso aos serviços, sendo também fortalecidos pelos sindicatos. Essas são as principais discussões sobre os burocratas de rua, que revelam a importância de estudar esse "grupo social" (LIPSKY, 1980, apud LOTTA, 2012, p. 10).

A discricionariedade desses agentes públicos também é um foco de análise na literatura. Originalmente, ou formalmente, a discricionariedade "é a qualidade daquilo que depende da decisão de uma autoridade com poder discricionário. O poder da discricionariedade é dado à Administração Pública para que esta possa agir livremente com base nos limites da lei e em defesa da ordem pública, garantindo a autoridade do público sobre o particular"13.

Marta Arretche (2001), ao analisar as avaliações de políticas e programas institucionais, aponta que a implementação das políticas corresponde a uma outra "vida" de um programa. Elabora que, no cotidiano, são os agentes públicos encarregados pelas implementações e não os seus formuladores que ganham centralidade. Os programas, de forma geral, supõem agentes que tomam as decisões e executores que as implementam:

Um programa, é então, o resultado de uma combinação complexa de decisões de diversos agentes. É claro que, nessa cadeia de interação, a concepção original, tal como apresentada na formulação, é, sem dúvida, muito importante, porque as decisões tomadas nesta fase já excluíram diversas alternativas possíveis. Mas esta é apenas uma das dimensões da vida de um programa. Na realidade, a implementação efetiva, tal como se traduz para os diversos beneficiários, é sempre realizada com base nas referências que os implementadores de fato adotam para desempenhar suas funções (ARRETCHE, 2001, p. 47).

\footnotetext{
${ }^{13}$ Fonte: Dicionário Jurídico - Direito Administrativo - DireitoNet. Publicado em 03/12/2009.
} 
Portanto, a autora anuncia que, na prática, são os implementadores que de fato fazem a política acontecer, de modos variados. Essas variações na implementação ocorrem por diversos fatores: por conhecer de fato o programa, por falta de informações ou capacitação sobre o mesmo, por não concordarem com os objetivos e, assim, estabeleceram suas prioridades de acordo com sua atuação, ou então, outras razões que podem, como incapacidade fiscal e administrativa ou alguma ligação de ordem política.

Visto isso, podemos dizer que as decisões tomadas pelo implementadores podem ser consideradas como um ato de discricionariedade, já que eles, como mostra a literatura, provocam grande impactos nas políticas devido à sua autonomia no momento da prática.

A discricionariedade desses agentes está em determinar a natureza, a quantidade e a qualidade dos benefícios, além das sanções fornecidas por sua agência. Assim, mesmo que dimensões políticas oficiais moldem alguns padrões de decisão e normas comunitárias e administrativas, esses agentes ainda conseguem ter autonomia para decidir como aplicá-las e inseri-las nas práticas da implementação (LOTTA, 2012, p.10).

Além dos relatos das gestoras de Laranjeiras apresentarem aborrecimentos às maneiras pelas quais foram instituídos os cursos promovidos entre a parceria e a prefeitura do município, suas ações apontam para uma experiência de discricionariedade no momento de implementar as aprendizagens e metodologias do curso no cotidiano escolar. Nesta parceria, elas ocuparam e ainda ocupam (visto que a parceria ainda está em vigor no município), uma dupla jornada: a de aprender e apreender metodologias para "melhorar" suas competências profissionais e a de colocar em prática essas competências na cultura de cada escola. A efetivação da parceria passa por esses dois momentos.

Como podemos observar, tanto nas falas das interlocutoras quanto na bibliografia apresentada, a efetivação, eficiência e eficácia das políticas públicas dependem necessariamente dos agentes públicos para implementá-las e, neste caso, as gestoras têm razões legítimas para não o fazer, pelo menos, plenamente, ou como a parceria prevê.

Neste cenário, eu também me coloco como uma burocrata a nível de rua ocupando dois lugares preeminentes: o de apresentar a política pública e o de ensiná-las a colocá-la em prática, entretanto, assim como as gestoras, eu também vivenciei a discricionariedade. 


\subsection{O Público e o Privado: interesses e politicagem na toada dos privilégios}

Este corset é muito desconfortável, então podemos acabar com isso logo e ir pra casa?

-Shuri, no filme Pantera Negra ${ }^{14}$

O clima político em Laranjeiras não é diferente de outras cidades. Há uma tensão que permeia toda a vida social, principalmente, tratando-se das e dos funcionários públicos. Quem você apoia, deixa de apoiar e/ou desafia pode mudar radicalmente os rumos da sua vivência social, cultural, econômica e trabalhista. Minha chegada ao município aconteceu alguns meses após às eleições municipais. Vereadores e secretários ainda estavam tomando posse e, juntos deles, diretoras de escolas e coordenadoras pedagógicas nomeadas para seus cargos, após apoiarem e fazerem campanha para o prefeito que saiu vencedor nas urnas.

Encontrei um clima belicoso entre as e os profissionais da educação, tanto da Secretaria quanto das escolas. Algumas transferências de pessoas para outras secretarias foram realizadas, havia um desconforto entre quem ficava e quem entrava para trabalhar naquela repartição. À época, a vice-prefeita assumiu a Secretaria de Educação, acumulando dois cargos, de vice e de Secretária. Ela me relatou que, naquele momento, não haviam encontrado uma pessoa "capacitada", "modernizada" para assumir aquela função e que ela já tinha sido professora e possuía uma escola particular no município. Portanto, ela conhecia bem as burocracias educacionais do município e do Brasil.

Foi ela quem assinou a carta de compromisso com a parceria, com a anuência e "mando" do prefeito. Tive a oportunidade de ter várias conversas com ela sobre a política local, os conflitos existentes e sobre o cotidiano dos laranjeirenses.

Os funcionários da Secretaria de Educação faziam parte de dois grupos políticos rivais, entretanto, a maior parte era rival do prefeito eleito, portanto, igualmente rivais da vice-prefeita. Após seis meses de mandato, ela abandonou o cargo, depois de uma discussão com as funcionárias. Foi embora no meio do expediente sem se despedir e nunca mais voltou.

Em seu lugar, foi empossado outro Secretário que já havia sido Secretário de Educação outras duas vezes e secretário de outras secretarias. Mesmo não sendo tão

\footnotetext{
${ }^{14}$ Quando a realeza de Wakanda é questionada se aceitam T'Challa como rei ou se gostariam de desafiá-lo, sua irmã Shuri ergue a mão, assusta a todos presentes e ainda solta esta frase que é um embate direto a uma peça de vestimenta patriarcal.
} 
"modernizado" e com a saúde frágil, ele foi uma aposta do prefeito para tentar diminuir os conflitos, pois o novo Secretário já tinha sido professor de muitos funcionários, gestoras escolares, inclusive da própria vice-prefeita, agora ex-Secretária de Educação. Todos o respeitavam pela sua senioridade, pela gratidão ao seu ofício de professor e pelo seu conhecimento da educação e do município.

Com a saída da Secretária, alguns funcionários que eram de outras repartições pediram para voltar aos seus postos originários, conforme os concursos públicos em que haviam sido aprovados. Sabiam, segundo alguns deles, que não conseguiriam ficar muito tempo vestindo aquele corset. Assim, seguiu-se o curso: a Secretaria, os profissionais da educação municipal, a parceria e eu.

As gestoras escolares que foram destituídas dos seus cargos por conta do novo cenário político, voltaram para a "sala de aula", ocupando a função de professoras e professores das disciplinas nas quais se formaram e pelas quais ingressaram no serviço público. No cotidiano escolar, os conflitos políticos também estavam estabelecidos, no entanto, havia uma cautela do lado "perdedor" naquele momento.

Outros relatos envolvendo a política local me rondaram durante a minha estadia em Laranjeiras, como trabalhadora, burocrata de rua, e como pesquisadora doutoranda. Exponho aqui os relatos que marcaram e fazem parte da minha pesquisa, ou seja, relatos concernentes à parceria público-privada na educação do município.

Acotirene - Podemos falar de todos os projetos, ou só desse?

Valéria-Podemos falar de outros, mas vamos focar nos que são parceria, tudo bem? Acotirene - Sim, sobre as parcerias mesmo que eu quero falar... Então, aqui ninguém é boba, já fomos bastante, mas tem tempo que sabemos quais projetos são bons mesmo, que vão servir para a nossa carreira ou do pessoal da Secretaria. Sabe aqueles projetos que são focados mais no pessoal? Tipo os de pós-graduação ou alguma especialização que a gente vai poder usar para outros concursos, ou até mesmo para aumentar nossos "pontos", então, esses já são destinados para algumas pessoas e são quase sempre as mesmas...

Laudelina de Campos - Nossa! Muito bom você falar isso... São sempre os mesmos e não é uma pessoa que recebe tudo, são as mesmas famílias. Não vou dizer os nomes delas, mas professora, você já deve ter notado o perfil das pessoas, né?

Valéria-Me fala mais desse perfil. 
Laudelina de Campos - É tipo a C (referindo-se a uma funcionária da Secretaria e que é concursada como professora).

Valéria - Tipo como?

Laudelina de Campos - Bom, resumindo... Pessoas mais brancas, casadas com homens que têm um cargo bom na empresa, que mandam os filhos para estudar na capital e que já não moram mais no município, moram em Aracaju.

Acotirene - E assim, não é culpa da pessoa, não é de agora, isso já vem há anos, as mesmas famílias são beneficiadas com tudo, sempre! Por exemplo, quando têm cursos bons da parceria que é para a nossa juventude, quem é escolhido? Os filhos, sobrinhos, netos das mesmas famílias que teriam condições de pagar. Eles pegam tudo sem nenhum constrangimento. Na verdade, quando a gente fica sabendo das coisas, já foi, já pegaram tudo. A gente sabe disso, mesmo quando a empresa oferece estágio, já sabemos quem vai fazer. Isso não é só aqui na educação, é em todo o município. Eu me preocupo com isso, não estou pensando só nas pessoas da minha família, porque eu tenho um pouco mais de condições, penso nos nossos alunos e nas famílias que não têm oportunidade de nada.

Acotirene - Professora, o problema do nosso município são as famílias tradicionais, sabe?

Valéria - E o que é essa família tradicional?

Acotirene - Se a gente for pensar que família tradicional é a que está aqui há muito tempo, a minha, ou as nossas também são, não é Laudelina? Mas estou falando das famílias que fizeram alguma fortuna desde lá de trás, ou com a escravidão, ou com a política. Muitos dos filhos e netos nem moram mais aqui, eles acham que Laranjeiras é velha e nada tem a oferecer. Até concordo, mas temos um passado, e a nossa cultura é muito viva, mas não tem investimento nenhum, aí vem também a questão da violência, né? Mas, de modo geral, essas famílias que já estão mais prósperas têm ligação direta com a empresa, então, a empresa, para agradar, para conseguir coisas... E isso a gente sabe bem, não é segredo para ninguém, quando querem algo, vão até elas e pronto! Agora, nossa juventude fica aí, na praça, tomando essas pingas vagabundas, roubando... É difícil.

Laudelina de Campos - Então é isso, a gente já sabe para quem os projetos são destinados, e a gente finge que acredita que vai ser para todo mundo... Elas acham que a gente é boba, mas sabemos de tudo. Fazer o que, professora, já brigamos muito, agora é melhor ser sonsa mesmo. E outra, quando é curso para nós, como esse que fizemos com você, a intenção deles é sempre a mesma, fazer a gente trabalhar de graça para eles, com 
coisas que a gente não concorda, que não tem nada a ver com o ritmo, com a cultura das escolas daqui e do município. Não sei o que eles pensam, nem sei quem inventa isso. Se eles quisessem mesmo ajudar a alavancar a educação do município, teriam que perguntar para nós o que queremos e precisamos, perguntar para as famílias e para nossos alunos, mas não... Eles vêm com coisas nada a ver com a gente e querem que implementemos a qualquer custo, aff... Dá até nervoso de falar.

Os relatos acima, do meu ponto de vista, informam-nos sobre os ciclos das políticas públicas, que, de forma geral, são homogêneas. Mas é interessante notar que as gestoras têm plena consciência do que está acontecendo e criam estratégias para sobreviver no mundo dos seus trabalhos de maneira mais "confortável". Acredito que essa situação de Laranjeiras se repete em outros municípios, principalmente nos menores, onde famílias antigas com situação econômica favorável, com poder político e de influência, conseguem se manter e perpetuar seus privilégios, enquanto a população demanda serviços públicos de qualidade e não os têm.

As parcerias, como foi dito, aproveitam-se dessa situação para se estabelecer no município, trazendo consigo seus ideais, metodologias e projetos, que nada têm a ver com a cultura local e com os modos de vida. São por essas brechas que elas se mantêm: ligação com as famílias que têm influência econômica e política, estruturas públicas preconizadas, desemprego, poucas perspectivas de mudança social a médio prazo, corrupção e pobreza.

É interessante notar que, nos serviços públicos, inclusive em Laranjeiras, é na educação que se concentra o maior número de mulheres trabalhando: de 2,2 milhões de professores atuando no ensino básico, 1,8 são mulheres ${ }^{15}$. Gênero aqui é um fator de grande relevância e faz toda diferença para a implementação ou não das políticas públicas.

Entretanto, mesmo com poucas possibilidades de mobilização, as gestoras, e não só essas da conversa acima, sabem o que acontece: os jogos de poder, quem manda, quem obedece e porque obedece, quem são os privilegiados e quem fica de fora. Elas criam estratégias para sobreviver às demandas que julgam não colaborar com suas funções e com a população por quem elas são responsáveis. Como burocratas em nível de rua, elas também se utilizam da discricionariedade como uma forma de resistência. "Quando me

\footnotetext{
${ }^{15}$ Fonte: Censo Escolar de 2017.
} 
atrevo a ser poderosa, a usar minha força a serviço da minha visão, o medo que sinto se torna cada vez menos importante" (Audre Lorde)

O projeto de nação das instituições requer esse chão desfavorável para a população precarizada, com o objetivo de implementar seus ideias e metodologias, uma nova forma de colonização pela educação, tentando utilizar como força de trabalho as mulheres, no caso de Laranjeiras, mulheres negras. Entretanto, pelo caminhar da carruagem, como foi visto acima, essa tarefa não será fácil e não sem resistências, afinal, lembrando a formosa e popular frase de Angela Davis (2006): "Quando uma mulher negra se move, o mundo todo se move com ela".

No próximo capítulo, tocamos justamente no ponto nevrálgico desta tese, qual seja: pensar os mecanismos de construção de uma nova nação, como querem as instituições pela educação supracitadas, uma forma de neocolonização, tendo como neocolônia a educação básica e pública e como neocolonizados todas e todos que participam direta ou indiretamente dela. Nosso foco ainda se volta às gestoras escolares de Laranjeiras, mulheres negras que refletem sobre esses processos e que, em alguma medida, desestruturam o plano de um novo modelo de nação comandado por grandes grupos empresariais.

Acredito que são essas mulheres - que, marcadas por um passado escravocrata e por um presente que abre lacunas para diferentes formas de abusos, que, por conta de vivenciarem mais profundamente esse cenário, de serem partes fundamentais dessa engrenagem - vão fazer a roda girar, mas não a da moenda. 


\section{Capítulo 4. Um Projeto de Nação: perspectivas neocoloniais e as parcerias público-privadas na Educação}

Aqui em Laranjeiras, nós temos alguns coletivos e uma militância forte pela preservação da nossa cultura, ainda bem! Todo ano é uma luta para podermos colocar os grupos culturais na rua no Festival Cultural. (...) A empresa, além de ter poluído nosso rio anos atrás, manda e desmanda nas secretarias, nos secretários, no prefeito. Todo mundo tem o rabo preso, todo mundo quer alguma coisa, mas eu não! Sou da militância desde de a faculdade. (...) Acontece o seguinte, a empresa vem e oferece de graça as estruturas para o festival, tipo palcos, shows, iluminação e tal, mas tem duas coisas: primeiro, elas querem pautar o que será apresentado e onde vão acontecer os cortejos, isso a gente não aceita. Já temos uma rota, ela é histórica e tem sentido para as comunidades. Segundo, a empresa cada vez mais quer trazer artistas famosos para cá. Pagam um cachê altíssimo para eles e os grupos daqui recebem o mínimo da prefeitura para fazer tudo, as roupas, preparar os tambores e os outros instrumentos, toda a produção. (...) Então, o que acontece é o seguinte, professora, a gente tensiona, temos grupos organizados, a gente já criou GTs para discutir isso, a gente bate na porta da prefeitura e da Secretaria da Cultura. (...) Tem muitas pessoas que acham bom essa intromissão da empresa, não sabem direito o que eu isso pode significar a longo prazo, mas a gente tá contando com muita ajuda, inclusive dos estudantes de arte da UFS [Universidade Federal de Sergipe] daqui, é uma luta! Há anos que a empresa quer direcionar tudo aqui, ela tem gente e projetos, não só na Secretaria de Educação de Laranjeiras, tem também na Secretaria de Finanças, na Secretaria de Cultura e tudo tem que ser do jeito que eles querem. Tem gente que aceita e tudo bem! Faz tudo que eles mandam e vão seguindo, mas tem muita gente que só finge que aceita, fala que tá fazendo mas não tá. Acho justo porque as pessoas têm que garantir seus empregos, a maioria são de cargos comissionados, então... eu mesma, cá entre nós, já participei de reunião grande com a empresa, cafezinho, sucos, lanches, tudo organizadinho, ouvi, coloquei o que eu pensava, sem brigar, mas na prática, não fiz nada daquilo que eles estavam querendo. Eu sou assim! Não vou fazer nada que vá, de alguma forma, prejudicar a comunidade, os pescadores, eles já passam por muitas dificuldades, que a empresa mesmo criou. (...) Eles [os pescadores] sabem bem se organizar entre eles, sempre souberam (Chica da Silva). 
Este capítulo realiza um percurso teórico, apontando as diferentes nuances do neocolonialismo e como esta perspectiva se intersecta com o projeto de uma "nova" nação preconizada pelos grupos empresariais, por meio de instituições que trabalham com a educação pública e básica brasileira. O objetivo aqui foi conectar os percursos seguidos até esta altura da tese com questões mais abrangentes e centrais à bibliografia socioantropológica, sinalizando os enraizamentos e articulações do que fomos até aqui notando como um verdadeiro projeto de nação que orienta as ações etnografadas, projeto este que é firmemente contestado e disputado conforme pretende se instalar. Portanto, veremos, também, como a perspectiva interseccional se movimenta nesse campo proporcionando um chão sólido, tensionando esse projeto, provocando desafios para sua implementação e permanência. O capítulo, assim, estrutura-se a partir do contraste entre os debates teóricos e disciplinares e trechos mais alongados de falas das interlocutoras da pesquisa, como o que abre este subtítulo, propondo uma triangulação entre suas vozes, as das autoras e minha própria. 


\title{
4.1. A Interseccionalidade como Tecnologia de Linguagem e Enfrentamento: um chão firme e forte
}

\author{
A Mudança não virá se esperarmos por outra pessoa, ou outros tempos. \\ Nós somos aqueles por quem estávamos esperando. Nós somos a \\ mudança que procuramos. \\ - Lélia Gonzalez
}

A epígrafe acima é de Lélia Gonzalez, pioneira em analisar de forma articulada as questões raciais, de classe e gênero (sexo). Gonzalez foi historiadora, filósofa e geógrafa e uma das fundadoras do Movimento Negro Unificado (MNU) - movimento que, ao almejar uma perspectiva socialista, fazia o enfrentamento às desigualdades raciais. Lélia Gonzalez contribuiu de forma original para o debate do feminismo negro no Brasil. Sua perspectiva de análise foi fundamental para os debates sobre produção e reprodução social, numa realidade marcada pelo racismo e pelo sexismo.

No artigo "Mulher Negra”, Gonzalez (1985) faz uma intersecção de raça, gênero, classe e região. Ainda na década de 1980, a intelectual apontava, por meio de dados e entrevistas, os lugares, diferentes e desiguais, que a sociedade neocolonial reservava para as mulheres e homens, negros e brancos.

A autora assinala que existe uma "divisão racial do espaço", uma segregação que coloca em desvantagem a população negra, afastando-a das regiões mais desenvolvidas do país, logo, de condições mais adequadas de vida, promovendo a solidificação das desigualdades. "Desde a independência aos dias atuais, todo um pensamento e uma prática político-social preocupados com a chamada questão nacional, têm procurado excluir a população negra de seus projetos de construção de nação" (GONZALEZ, 1985, p. 1).

Essa lógica interna, que cristaliza as desigualdades, uma lógica capitalista que fez parte do desenvolvimento econômico do Brasil, Gonzalez nomeia "colonialismo interno", submetido aos ideais neocoloniais.

Lélia é considerada uma das primeiras intelectuais brasileiras a trabalhar com o que hoje se nomeia interseccionalidade, justamente, por trazer em seus escritos reflexões que colocam, principalmente, a população negra nos seus múltiplos contextos sociais e o racismo como uma articulação ideológica, com destaque à posição ocupada pelas mulheres negras. Nesse sentido, Lélia Gonzalez critica não somente as formas de reprodução do capitalismo, mas também o Movimento de Mulheres, que não levava em 
consideração as mulheres negras e pobres. No artigo "Mulheres Negras", a autora traz o seguinte relato:

Por ocasião da reunião em que seria tirado o nome daqueles que representaria o MM no comício das diretas do dia 21 e março no Rio, uma militante feminista branca, não aceitando a indicação de uma mulher negra favelada, declarou, com todas as letras que "mulher de bica d'água não pode representar as mulheres" (GARCIA, 1984).(...) por esses e outras é que se entende porque os grupos de mulheres negras se organizam e se organizam a partir do MN e não do MM. Aliás, as pouquíssimas negras que militam apenas no MM têm muita dificuldade no sentido de se aprofundar no que diz respeito à questão racial. Talvez porque achem que no Brasil não existe racismo (porque, como disse Millor Fernandes, "o negro sabe onde é seu lugar") (GONZALEZ, 1985, p. 10).

Para a autora, entre outras coisas, o Movimento de Mulheres reproduzia o "Imperialismo Cultural" que não estava somente no MM, mas em outros lugares de atuação dessas mulheres brancas, por exemplo, nas escolas, em que, se utilizando de uma "autoridade colonialista", reproduziam os privilégios de raça, gênero e classe por meio do saber.

O tema do imperialismo e seus contornos está presente em outras autoras igualmente atentas à questão das articulações de formas de desigualdade e diferença, ou interseccionalidade, principalmente quando o embate remete às questões de raça e gênero e classe. Anne McClintock (2010) é uma dessas autoras, como vimos no Prelúdio desta tese. Para ela, gênero é uma categoria constitutiva do imperialismo, no entanto, não é a única dinâmica e nem a predominante, assim, a autora apresenta outras categorias, como classe, sexualidade e raça, operando uma em relação à outra de modo sempre articulado - não há categoria predominante.

McClintock ponta que, no embate colonial, homens e mulheres colonizados tiveram experiências distintas. No caso das mulheres colonizadas, elas enfrentavam duas estruturas de desigualdade: na relação com os homens colonizados e com os homens e mulheres brancas do império. Aqui, raça e gênero são articuladores, tanto de um lado como de outro, marcam hierarquicamente todas as posições que as pessoas ocupam.

As mulheres brancas (coloniais) do império habitaram uma situação ambígua e também experimentaram as vantagens e as contradições sociais de maneiras diferentes da dos homens brancos (coloniais). Embora estando longe das arenas políticas e do poder formal, exerciam grande poder sobre as mulheres e homens colonizados. Fossem essas mulheres brancas locadas para a servidão doméstica, sexual ou primorosas esposas de 
oficiais, aqui é o privilégio da raça e não do gênero que sustenta a situação de poder. Anne McClintock observa que, "Como tais, as mulheres brancas não eram as infelizes passantes do império, mas cúmplices ambíguas, tanto como colonizadoras quanto como colonizadas, privilegiadas e restringidas, fossem passivas ou ativas" (McCLINTOCK, 2010, p. 22). Nos dois casos o desequilíbrio de poder permeia essas relações.

Para a autora, gênero não é sinônimo de mulher e raça não é sinônimo de negro ou colonizado. Ela está de acordo com a teoria feminista negra que analisa não ser possível estudar as mulheres isoladamente e que gênero é uma questão tanto para a masculinidade como para a feminilidade, assim como para a compreensão das relações raciais. Salienta que gênero no imperialismo assumiu diferentes formas nas diferentes colônias. Estas distinções influenciaram no modo de operação do racismo científico.

McClintock assinala que, com o racismo da mercadoria, o imperialismo articulase constitutivamente com a domesticidade. A mercadoria doméstica, em especial o sabão, demonstra o progresso imperial e do capitalismo. No quadro interpretativo da autora, para o colonizador, a civilização avançava através de seus quatro fetiches: o sabonete, o espelho, a luz e a roupa branca.

Nesse processo, por um lado, o lar vitoriano tornou-se um lugar de exposição do espetáculo imperial e da invenção da raça e, por outro, colônias africanas tornaram-se espaço de exibição do culto da domesticidade e da recriação do gênero. A autora ressalta que:

O imperialismo difundiu o culto vitoriano da domesticidade e a separação histórica entre o privado e o público, que tomou forma em torno do colonialismo e da ideia de raça. Ao mesmo tempo, o colonialismo se formou em torno da invenção vitoriana da domesticidade e da ideia do lar (McCLINTOCK, 2010, p.64).

A racialização do espaço doméstico e a domesticação do espaço colonial são pontos centras de análise da autora.

Vocês podem estar se perguntando o porquê de trazer para esta seara as temáticas referentes ao imperialismo, capitalismo, movimentos negros e de mulheres, os embates coloniais e interseccionalidade. Minha aposta é que, ao discorrer sobre estes temas, poderemos elaborar análises críticas e de enfrentamento ao que pode ser chamado de neocolonialismo, como veremos mais à frente. A perspectiva política da interseccionalidade é um dos chãos em que se firma essa crítica. 
Flavia Rios e Edilza Sotero (2019) destacam que a interseccionalidade recentemente se tornou um paradigma essencial para as ciências sociais. Uma das expoentes do conceito de interseccionalidade é a estadunidense Kimberlé Crenshaw (1991), que, no contexto de discriminação e luta por ações afirmativas no país, enuncia que, se as mulheres estão sujeitas ao fardo da discriminação de gênero, entretanto, há também outros fatores que incidem sobre o modo como diferentes grupos de mulheres experimentam a discriminação. Raça, classe, religião, região e sexualidade são alguns desses.

Crenshaw (1991) aponta que as mulheres negras estão localizadas de forma desigual entre os sistemas políticos, econômicos e sociais e, com isso, é provável que, se mulheres negras não tiverem políticas específicas, terão menor chance de alcançar seus objetivos se comparadas com mulheres brancas e homens.

\begin{abstract}
Mulheres pertencentes a minorias sofrem o efeito de múltiplas subordinações. Essas subordinações, aliadas a previsões institucionais que se baseiam indevidamente em contextos não interseccionais, acabam por construir cenários que limitam intervenções significativas a favor dessas mulheres. Quando consideramos as dinâmicas interseccionais, também conseguimos entender e explicar os altos índices de fracasso, frustração e desgaste vividos pelos profissionais que atendem às necessidades das vítimas oriundas de grupos minoritários (CRENSHAW, 1991, p 14).
\end{abstract}

Rios e Sotero (2019) apresentam as discussões recentes em torno do conceito de interseccionalidade. Apontam que, na América Latina, a interseccionalidade dialoga, em alguma medida, com as teorias decoloniais, propondo uma análise crítica das opressões provocadas pelos processos de produção do sistema colonial.

Há algumas colisões em torno da interseccionalidade e, principalmente, de como ela é manejada em algumas situações. Por exemplo, autoras como Ochy Curiel (TEIXEIRA, SILVA e FIGUEIREDO, 2017) e Carla Akotirene (2018) criticam a proposta de interseccionalidade de Crenshaw por, na visão delas, ter um viés neoliberal.

Para Curiel, a proposta de Crenshaw traduzida na interseccionalidade, estaria ancorada em uma perspectiva liberal, mais preocupada em produzir demandas por reconhecimento do que projeto de emancipação. Perdendo, assim, a capacidade de crítica substantiva ao processo de produção das opressões, antes as compreendendo como algo dado na conversão de diferenças em desigualdades (RIOS \& SOTERO, 2019, p.3). 
Guardados os devidos embates, no Brasil, segundo as autoras, o movimento feminista negro, junto com os estudos de gênero e raça já estabelecidos nas academias, e a tradução de intelectuais norte-americanas tem atuado no sentido de trazer para o debate seus conceitos, o que fez com que a interseccionalidade se tornasse uma perspectiva potente.

Seguindo na mesma linha, Laura Moutinho (2014), em seu artigo "Diferenças e desigualdades negociadas: raça, sexualidade e gênero em produção acadêmica recentes", faz uma reflexão sobre os debates que envolvem as políticas de reconhecimento e as novas possibilidades semânticas das noções de raça, gênero, sexualidade e nação, articuladas no campo da interseccionalidade. A autora aponta que, nos Estado Unidos, a interseccionalidade se configura como um campo de estudos singular.

Moutinho cita Kimberlé Crenshaw como uma das pioneiras da articulação desse campo, em que raça, gênero e classe são interseccionados em uma construção reflexiva, crítica e política sobre a exclusão de mulheres negras.

Kimberlé Crenshaw é uma acadêmica extremamente atuante, sendo cofundadora do African-América Policy Forum. O Forum está estruturado em três eixos: ações afirmativas, interseccionalidade e racismo estrutural. O objetivo é conectar acadêmicos, ativistas e formuladores de políticas no sentido de enfrentar as desigualdades estruturais que têm como base as intersecções entre gênero, raça e classe (MOUTINHO, 2014, p.5).

Laura Moutinho, ao refletir sobre os estudos, as pesquisas, as intelectuais e os movimentos que têm a interseccionalidade como uma medida essencial para lidar com o tema da exclusão e da desigualdade, aponta algumas questões sobre como o termo foi sendo utilizado em diferentes esferas do saber. Apresenta três argumentos para reflexão, entendimento e enfrentamento acerca do tema. São elas: há uma tendência em trabalhar a interseccionalidade como uma finalidade e não como ponto de partida; existe, de alguma maneira, uma justaposição de exclusões, os estudos não apresentam uma proposição concreta que articule os diferentes marcadores, raça, gênero, sexualidade, classe, região, etc.; e há uma inclusão ou aderência precária dos marcadores gênero e sexualidade nos estudos e movimentos que têm a perspectiva das relações raciais como central.

Laura Moutinho anuncia a importância da interseccionalidade nas pesquisas e nos debates acadêmicos no momento em que os marcadores sociais da diferença, raça, gênero, classe e sexualidade, estão sendo discutidos e avaliados a todo vapor. 
Parto da afirmação de que não é possível pensar em categorias funcionando isoladamente. Ainda que de modo desigual e contraditório, nenhum desses marcadores sociais, sejam quais forem os contextos, permanece invisível ao longo do tempo e do espaço. Eles operam como um paradoxo, como um desencaixe. Raça, gênero, classe, sexualidade, região, dinheiro e poder, não são apenas dispositivos de exclusão, mas categorias de experiências que constroem realidades.

Notamos esses entrecruzamentos de poder entre raça, gênero e classe na fala de Chica da Silva que, como ela mesma nota, tem muita leitura do mundo. Ocorre-me afirmar que, de fato, interseccionalidade é um conceito que emerge de relações vividas:

Eu agora estou estudando o Racismo Ambiental, já ouviu falar? Estou me empenhando, lendo bastante, participando de discussões na universidade. Sempre gostei de estudar raça, mas confesso que li pouco, fiquei um bom tempo na linha de frente da militância, mas sem muita leitura, tenho leitura do mundo, mas, estudar a fundo pessoas que pesquisam, que já têm um tempo de experiência em raça, está me fazendo abrir mais meus olhos. (...) Para mim, o racismo ambiental é muito perverso, principalmente para Laranjeiras. Na verdade, sempre existiu, mas agora ele está mais forte. Esses projetos ambientais das empresas, por exemplo, de proteção aos nossos rios, à mata, aos pescadores, que são quase todos pretos, enfim, os mais humildes do município, só servem para manter as pessoas no mesmo lugar, fazer elas acreditarem que elas são responsáveis pelo cuidado do rio, mas eu pergunto: e o saneamento básico? Não tem esgoto na maioria das casas... (...) Elas [empresas] fazem esses projetos, se fazem de boazinhas, que estão ajudando o município, mas não é verdade, pode acreditar, é tudo enrolação para as empresas ganharem mais prestígio, terem desconto nos impostos, se apropriarem das culturas locais. Querem dominar tudo, saber de tudo, interferir na vida das pessoas e manter o povo no mesmo lugar(...). No nosso município, a maioria da população é composta por mulheres pretas, muitas bem formadas, com nível superior, que não estão em situação de pobreza, de muita pobreza, mas a maioria está na roça, na pesca, recebendo um salário mínimo de subsídio do governo federal, passando muita necessidade. Os pescadores, um monte deles passa o dia inteiro no bar bebendo, não podem pescar porque não tá na época ou não podem porque, vira e mexe, uma parte do Contiguiba [rio que corta a região] está com o nível de poluição alto. E assim vamos levando. Mas não se assusta, tem muita coisa boa em Laranjeiras, eu amo esta cidade! (Chica da Silva). 


\subsection{Identidade e Desigualdade, entre Sociologia, Antropologia e os Debates sobre Colonialidade e Pós-Colonialismo: um percurso entre autores}

Em 1998, Pierre Bourdieu e Loïc Wacquant escreveram o texto "Sobre as Artimanhas da Razão Imperialista". Neste texto, os autores criticam a forma como elaborações acadêmicas de grandes centros do poder - expressões de um universo particular - são transpostas para analisar contextos completamente diferentes. Um dos pontos abordados no texto é o debate sobre raça na América Latina, onde este conceito é, para os autores, materializado de forma distinta do que acontece nos EUA. A grande crítica refere-se a estudos de pesquisadores dos Estados Unidos que, com foco nas desigualdades, apontam para uma divisão racial em sociedades da América Latina conforme a existente nos EUA. Bourdieu e Wacquant consideram que estes estudos, ao apontarem para um binarismo racial entre branco e negro, importam a lógica racial estadunidense para pensar experiências opostas a esta, desde que consideram a América Latina, mais especificamente o Brasil, um "contraexemplo do modelo americano".

Os estudos aos quais se referem os autores apontam que as desigualdades existentes entre negros e brancos na América Latina não diferem estes países dos EUA. O grande exemplo trazido no artigo é Michael Hanchard, autor do livro Orfeu e o Poder. Hanchard aponta que o racismo brasileiro é ainda mais perverso e dissimulado que o americano, o que, para Bourdieu e Wacquant, é uma leitura pautada na lógica das relações raciais norte-americanas.

Vale lembrar que Bourdieu e Wacquant desconsideram que as ciências sociais brasileiras sempre sofreram forte influência de produções europeias e norte-americanas em diferentes campos, não somente nos estudos sobre relações raciais, e que, muitas vozes, inclusive aquelas que tentavam produzir um posicionamento interno sobre as desigualdades entre negros e brancos no país, foram silenciadas por essas teorias gerais sobre cultura e sociedade (PINHO; FIGUEIREDO, 2002).

Para os autores, Hanchard não compreende a dinâmica racial brasileira dentro de sua própria ordem e tenta substituir o mito da democracia racial pelo mito da sociedade racista. Poderíamos considerar que Bourdieu e Wacquant têm um olhar muito influenciado pela antropologia brasileira, campo onde ganhou forma conceitual a ideia de encontro racial sem conflitos. 
A antropologia francesa - que tem grande influência na formação da antropologia no Brasil - se constitui, conforme Muchielli (1997), a partir do conceito de raça, este fundamental para definir a escala de civilização - onde a relação entre raça e cultura era uma relação de um para um. É na primeira metade do século XX que Gilberto Freyre, influenciado pela quebra de paradigmas provocada por Franz Boas - que rompe com as hierarquias raciais na antropologia ao separar raça de cultura -, escreve que o Brasil é uma "democracia racial" onde poderia haver um encontro harmonioso das "raças", e que a Casa Grande e a Senzala não refletiam apenas contradições. A "democracia racial" reduzia as contradições raciais no Brasil à ideia de que aqui ocorre "uma das uniões mais harmoniosas da cultura com a natureza e de uma cultura com a outra que as terras do hemisfério já conheceram" (ANDREWS, 1997, p. 98). Mesmo rejeitando a ideia do caráter degenerativo do mestiço, propagada pelo racismo científico, acreditando na capacidade destes, Gilberto Freyre mascarava os conflitos e ideologias racialistas que estavam sendo operacionalizados no país ao reforçar que no Brasil não existe fronteiras de cor entre os povos.

Hofbauer (2011), a partir de um panorama histórico dos estudos sobre raça e cultura no Brasil, afirma que os estudos sociológicos sobre as diferenças tenderam a enfatizar mais as desigualdades que as mesmas produzem, enquanto a antropologia preocupou-se historicamente com noções de autenticidade e tradição, tomando a diferença sinônimo de diversidade cultural. Este foco na diferença como diversidade teria distanciado a antropologia da discussão sobre relações e poder e dificultaria que esse campo se posicionasse frente às contradições sociais. Já a sociologia, ao longo do século $\mathrm{XX}$, teria revelado as grandes contradições produzidas pela noção de diferença na sociedade brasileira, sendo os estudos UNESCO um marco referencial.

A antropologia tem uma história marcada pela associação direta entre grupo racial, etnia e cultura. No século XIX se consolida como ciência com o objetivo de analisar sociedades que vinham sendo colonizadas pelo Ocidente. Sob a ótica de um determinismo evolucionista e racial-biológico, neste momento, ideias como "raça" e "cultura" eram tomadas como equivalentes. Foi Franz Boas que rompeu com essa relação de um para um ao "opor-se a que o mundo das culturas fosse subjugado a "leis naturais"”. A obra de Franz Boas possibilitou uma contraposição aos sistemas discriminatórios presentes em modelos como o evolucionismo, mas não deu conta de analisar "dinâmicas culturais internas" (HOFBAUER, 2011, p. 74-75). 
Fredrik Barth em “Os Grupos Étnicos e Suas Fronteiras” (2000) apresenta uma resposta para a análise das dinâmicas culturas internas e foi responsável por uma quebra de paradigmas, trazendo novas concepções para se pensar a questão da etnicidade e cultura.

Barth também se preocupa com o fazer antropológico e com as possibilidades de enfrentar novos desafios teóricos (BARTH, 2000). O autor aponta para o problema da definição de grupo étnico no que tange à aplicação de direitos e enuncia que esses grupos, ao assumir sua identidade étnica, reivindicam reconhecimento do Estado.

Barth (2000) suspende o conceito de cultura ao analisar os limites entre os grupos étnicos. Aponta que não são os conteúdos culturais que encerram e definem as diferenças entre os grupos, as diferenças consideradas objetivas não dependem mais de um observador externo que as contabilize e a classifique. Ao se abordar a contrastividade cultural, as diferenças são explicitadas pelos próprios atores, são eles, inclusive que vão apontar as diferenças que julgam significativas. Embora as diferenças possam mudar, permanece a dicotomia entre "nós e eles". o autor enfatiza:

Em primeiro lugar, enfatizamos o fato de que grupos étnicos são categorias atributivas e identificadoras empregadas pelos próprios atores: consequentemente, têm como característica organizar a interação entre as pessoas (BARTH, 2000, p.27).

É possível averiguar que, para o autor, a característica definidora de grupos étnicos é serem tipos organizacionais definidos por categorias como "nós e eles", e isso se deve, também, à situação de contato com grupos de diferentes culturas. As interações sociais selecionam e estabelecem traços físicos, culturais, valores, signos diacríticos para definir formas e padrões de relacionamento e comportamento. A partir disso, o surgimento e a manutenção das fronteiras étnicas se tornam compreensíveis.

Além de Fredrik Barth (2000), autoras e autores como Manuela Carneiro da Cunha (2009) e John e Jean Comaroff (2009), recentemente, analisam as maneiras pelas quais a identificação étnica se torna uma das principais fontes de ação e agência nas negociações comerciais e políticas. Por meio das pesquisas desses autores, realizadas em diferentes contextos, é possível observar como a etnicidade é elaborada e ativada em determinados embates sociais e políticos.

John e Jean Comaroff (2009), nas suas pesquisas, analisam a incorporação da identidade no mercado. Apontam a entrada no mercado de novos elementos da esfera da existência humana, como os rituais, as crenças religiosas, as práticas tradicionais de cura, 
os símbolos identitários de um grupo. Os autores elaboram o conceito de comodificação da cultura e definem etnicidade como a participação de um povo culturalmente constituído e ligado afetivamente por um variado conjunto de sinais culturais. Entretanto, apontam que a etnicidade passa a ser construída e explorada pelo neoliberalismo e, da mesma forma que as mercadorias estão se tornando culturais, a cultura está sendo comodificada.

Apesar de saberem que esse é um fenômeno de longa data, John e Jean Comaroff, argumentam que na atualidade houve uma ampliação econômica e política desse tipo de comércio. Para os antropólogos, a sobrevivência cultural tem dado lugar a uma sobrevivência através da cultura. No mercado, a etnicidade pode criar novos padrões de sociabilidade e fortificar a subjetividade cultural. Isso acontece porque a versão comodificada dos artefatos e das práticas culturais dos grupos tornam-se reconhecidas como autênticas.

Certos de que a comodificação da cultura acontece de maneiras diferentes ao redor do mundo, John e Jean Comaroff consideram que a pesquisa etnográfica em diferentes contextos é imprescindível, pois pode revelar quem se beneficia efetivamente desses processos. Ambos convidam os antropólogos a verificar como esses artifícios podem variar e revelar novas correlações.

Manuela Carneiro da Cunha (2009) por sua vez, recupera a cultura como um argumento político, instrumento de defesa da propriedade intelectual dos grupos. Os estudos sobre os grupos étnicos da diáspora e organizações indígenas trazem algumas ponderações sobre o uso da etnicidade. Para a autora, não se podem definir grupos étnico a partir de sua cultura, embora ela entre de modo essencial na etnicidade servindo como substrato. Isto porque cultura não é algo dado, ela é constantemente reinventada e investida de novos significados.

No processo de construção da identidade ética são extraídos da tradição elementos culturais como se eles fossem idênticos a si mesmo, ocultando o fato de que esses elementos que foram extraídos passaram por modificações. "Em outras palavras, a etnicidade faz da tradição ideologia, ao fazer passar o outro pelo mesmo: e faz da tradição um mito na medida em que os elementos culturais se tornaram 'outros"” (CARNEIRO DA CUNHA, 2009, p. 239). No entanto, a autora também questiona em que medida a etnicidade seria uma ideologia e, quem seria o mais verdadeiro, o outro ou o mesmo?

Ao marcar distinções étnicas, os grupos realçam traços diacríticos para balizar diferenças, como a religião, as vestimentas, a língua, os costumes, a arte, a ancestralidade, 
a culinária, de acordo com as categorias existentes na sociedade em que vivem. Utilizam, portanto, de um "acervo cultural" de onde são retirados esses traços diacríticos.

Ao compreender a etnicidade como forma de organização política, Manuela Carneiro da Cunha a aproxima de outras formas organizacionais como as religiosas ou de parentesco. A etnicidade é uma forma importante de interpelar políticas públicas e devemos considerá-la como uma categoria "nativa" usada por determinados agentes sociais na qual ela faz sentido.

Com isso, a autora mostra as formas situacionais e contrastivas que os processos de identidades são construídos fornecendo uma resposta política a uma determinada situação articulada com outras identidades em jogo. Os grupos sociais mobilizam identidades e os discursos identitários são causa e não consequência da cultura. Nesses discursos, o que importa não são as diferenças, mas a tomada de consciência das diferenças.

As ideias do século XIX contribuíram para formar uma concepção de cultura como algo homogêneo, fixo e não deslocada da identidade. Somente a partir dos anos 1970, através de contribuições de intelectuais como Pierre Bourdieu (1974) e Marshall Sahlins (1981), é que tem início uma valorização dos sujeitos sociais como agentes dentro da dinâmica cultural, deslocando a cultura de lugar estático para o de fenômeno que se dinamiza a partir da ação e interação dos indivíduos (HOFBAUER, 2009, p. 103).

Desde o final do século XX, a disciplina antropologia segue o caminho de desconstrução das noções de autenticidade e tradição cultural, alertando para as variações internas presentes em um mesmo grupo e, concomitantemente, se ateve às ideologias tradicionalistas como forma de resistir à modernização. A mudança levou a uma reconceitualização das noções de sociedade e cultura, valorizando, como método, a pesquisa sobre a ação, políticas de identidade e os artifícios simbólicos. A discussão sobre identidade neste campo passa também por um processo de mudança, ocasionado pelas reivindicações e mobilizações sociais de diversos grupos étnicos (ERIKSEN, 2001).

Para Eriksen (2001), este deslocamento do estudo de "culturas tradicionais fechadas" para políticas de identidade e agenciamento ocasionou uma quebra de paradigmas no campo antropológico: essencialismo e primordialismo passam a ser vistos como ideologias pré-darwinianas. Desse modo, abandona-se a noção de cultura estática, dando lugar a um fenômeno dinâmico e interativo.

Os antropólogos da chamada virada literária, que tem início com a antropologia interpretativa de Geertz, trazem uma crítica ao essencialismo e homogeneidade presentes 
nas leituras clássicas em antropologia e, posteriormente, as contribuições pós-modernas passam a questionar a autoridade etnográfica (autores como James Clifford, Lila AbuLughod etc.). Através da antropologia interpretativa e uma crítica aos textos etnográficos modernos, Geertz (1989) propõe uma análise hermenêutica da cultura. Assim sendo, esse autor abriu espaço para que, posteriormente, o projeto dos pós-modernos rompesse com a autoridade do etnógrafo presente aos trabalhos clássicos da disciplina. A estratégia usada para chegar a esse objetivo foi a valorização das múltiplas vozes (relação dialógica entre pesquisador e pesquisado) que dinamizam a vida em sociedade (HOFBAUER, 2009). É neste momento que a discussão sobre relações de poder no que se refere à cultura e a construção das diferenças entra em cena na teoria antropológica, florescendo os conceitos identidade e etnicidade.

A identidade seria um conceito que nos possibilita pensar as fronteiras grupais. Já a cultura, no contexto atual, não daria conta dessa discussão. Identidade étnica é um processo relacional de criação e recriação contínua em contextos específicos. As diferenças culturais atravessam fronteiras étnicas, ou seja, podem existir fronteiras étnicas sem correspondentes diferenças culturais (ERIKSEN, 2001).

Se a virada literária e as críticas pós-modernas marcaram a antropologia da segunda metade do século XX, um novo movimento ganha expressividade nos primeiros anos do século XXI: a virada ontológica. Se Franz Boas rompe com regimes de hierarquização ao separar raça de cultura para falar das diferenças humanas, ele não rompe com o paradigma hierarquizante ao dicotomizar natureza e cultura. De acordo com Amiria Henare, Martin Holbraad e Sari Wastel (2007), se os diversos grupos sociais pensam por meio das coisas, o antropólogo deveria tentar fazer o mesmo exercício. Quando a cultura é tratada como aparência da realidade, abre-se possibilidades para considerar de que modo essas representações se constroem. Se considerarmos que a busca por representações da realidade é um projeto da ciência moderna, a referência privilegiada sempre será a ocidental. Essa é uma herança positivista das ciências sociais, o antropólogo escolhe representações segundo seus próprios parâmetros e as privilegiadas seriam as mais "verdadeiras".

A partir disso Henare, Holbraad e Sari Wastel (2007) avançam em uma crítica ao relativismo cultural, que representaria também uma herança positivista. O postulado em questão é o seguinte: se o mundo é aprendido por meio de representações, então a realidade ou verdade seriam apenas propriedades nas quais nós investimos. Como, do ponto de vista lógico, os relativistas podem afirmar sem contradição que as nossas 
representações, que são também parciais em relação a outras, conseguem dar conta delas? A tradução transcultural pode se dar somente se existir um ponto de convergência ou de comparação; em contraposição a essa perspectiva, a visão ontológica implode esses pressupostos e, "humildemente", reconhece que nossos conceitos são inadequados para traduzir os dos outros. Esse é um importante ponto de partida para levar a sério a alteridade.

Nessa perspectiva, a natureza é um espelho onde diferentes grupos exprimem sua própria imagem, tudo que temos são "visões alternativas de mundo". Ao tentarem traduzir as nuances dos outros, não assumem uma posição parcial e suficiente para traduzi-los. Isto porque, qualquer tradução de outra cultura é mediada por algum ponto de comparação, ou seja, o antropólogo fala de um lugar. Quando os relativistas trazem o pressuposto de que os outros veem o mundo "de uma forma diferente do que fazemos", ignoram a potencialidade das coisas (HENARE, HOLBRAAD e WASTEL, 2007). Os autores também apontam que, mesmo nós, antropólogos, sendo capazes de conceber a coisa e o conceito, isso não nos coloca como superiores aos interlocutores. É preciso admitir quando nossos conceitos são inadequados e precisam ser transformados pelo que nos demonstra nossos informantes.

Em seus diferentes momentos de virada, a antropologia tem se detido nos temas identidade e diferença. No entanto, ao meu ver, por mais que se questione a autoridade do etnógrafo, que se afirme o quanto é importante levar em consideração as narrativas dos nativos e que se valorize uma abordagem contextualizada, pouco se fala sobre o papel da antropologia em se posicionar frente à realidade gerada por esses temas: as desigualdades.

Sabemos que a sociologia nasce com o objetivo de estudar os fenômenos e convenções sociais, sendo que, em sua gênese, a raça biológica não ganha a mesma centralidade dada no campo antropológico. Nos clássicos Marx, Weber e Durkheim há diferentes leituras no que tange à ideia de raça.

Este conceito também não ganha espaço da teoria marxista, para a qual, conforme Guimarães, "certas ideologias e certas hierarquias se assentavam na natureza, tais como os sexos ou as raças" e "a formação das classes centrais à reprodução e à eventual revolução das sociedades capitalistas estaria estritamente relacionada às suas formações sociais" (GUIMARÃES, 2014, p. 3). Para Marx (1970), a luta de classes é o motor da história e os modos de produção envolvem modos de apropriação, poder e exploração. $O$ 
que diferencia os sujeitos são as classes sociais, o lugar que ocupam na sociedade, tendo como perspectiva o dualismo proletariado-burguesia.

Dentre os clássicos é Weber quem passa a levar raça a sério como construção social. Em “Grupos Étnicos” (1994), baseando-se na experiência dos EUA, Weber inova conceitualmente ao romper com a biologização e demonstrar que, para a sociologia, o que importa é como questões sociais são impulsionadas pela crença nas raças, ou seja, como essa crença se reflete na distribuição do sistema econômico. Para Weber, nossa relação é mediada por objetos, ou seja, o mundo físico faz parte da explicação, mas não há determinismo material (WEBER, 1994; GUIMARÃES, 2014).

Ao longo do século XX a sociologia começa a redesenhar um caminho para a interpretação da ideia de raça. Se a princípio tínhamos o predomínio de um modelo mais duro, estruturalista, onde os sujeitos têm um papel reduzido no interior de uma ordem institucional e pouca atenção se dá aos seus enunciados, a partir da década de 1960 o neomarxismo - que emerge da Escola de Frankfurt - dá especial atenção à forma como os sujeitos coletivos têm importância na história e em como suas ações orientam a transformação da sociedade.

A luta pela dominação da "consciência de classe", proveniente do marxismo, é tomada por Bourdieu, autor que produz obras fundamentais para as ciências sociais entre os anos 1960 e 1980. Para ele, a dominação se exerce sempre por meio de violência, seja ela simbólica ou pela coação física, sobre as consciências ou sobre os corpos. Os agentes sociais agem e pensam de acordo com "constrangimentos estruturais". Bourdieu contraria o pensamento positivista ao levar em consideração que os objetos de estudos pensam e falam e, embora seja crítico à eliminação do sujeito do pensamento estruturalista, adota esta corrente como método ao buscar na interação entre os agentes e as instituições uma estrutura historicizada que se impõe aos pensamentos e ações. $O$ autor relaciona consciência e possibilidades de existência às práticas e às ideologias e os elementos que impactam de forma significativa sobre o indivíduo. Abre precedentes para pensar como o elemento simbólico atribui uma identidade para determinados grupos, naturaliza a dominação e alimenta a ação (BOURDIEU, 1974; 1989).

A teoria de Bourdieu traz mudanças sobre a percepção dos sujeitos e seus enunciados tanto para a sociologia como para a antropologia. A partir dos anos 1980 novos movimentos teóricos redesenham o campo da sociologia: pós-modernismo, teorias dos sistemas, construtivismo, pós-colonialismo, feminismo etc. O diálogo com essas 
novas disciplinas possibilita uma virada histórica no campo das ciências sociais, sendo que as primeiras também se alimentam das produções desta última (KUHN, 1996).

Conforme Guimarães (2014), raça aparece como conceito "mais maduro" na sociologia estadunidense, onde houve um exercício acadêmico para pensar a operacionalidade dessa categoria em cinco escolas: teoria das etnicidades; teoria das classes; teoria nacionalista; teoria da formação racial e teoria da racialização.

A primeira é a teoria da etnicidade, na qual a raça seria apenas uma das formas possíveis de constituição do grupo étnico, ou seja, de um grupo que se define a partir de marcadores de origem e de hereditariedade (...) A segunda teoria importante nos Estados Unidos, uma teoria de origem marxista, é na verdade uma teoria das classes, em que a raça apenas facilita, de certo modo, a distribuição desigual de recursos econômicos nos mercados (...) A terceira teoria, poderíamos dizer nacionalista, é aquela para qual as comunidades raciais são potencialmente nações. Nas Américas, a raça negra seria produto da colonização europeia, e viveria sob condição de colonialismo interno. (...) A quarta teoria é a da formação racial (Omi e Winant, 1986), que se centra na concepção de raça como um processo histórico de construção sociopolítica. (...) As raças, nessa teoria, seriam processos em constante construção. Por fim, mais recente, ocorre um desdobramento teórico muito interessante com a ideia de racialização, conceito que remete aos processos de atribuição de sentidos ou identidades raciais a relações que antes eram desprovidas de tal significação (...) (GUIMARÃES, 2014, p. 7-8).

O processo descrito até aqui se reflete na sociologia brasileira, onde as primeiras escolas procuravam dar ao conceito raça um lugar biológico, e aplicá-lo às explicações do social. Empregada no final do século XIX por teóricos como Nina Rodrigues, raça era lida em uma perspectiva naturalista. Em um segundo momento, é abandonada pela sociologia, mas não deixa de ser um operador ideológico que passa a ser esconder atrás da ideia de "cultura". Posteriormente, ainda de forma velada, raça aparece nos estudos sobre os modos de produção, ou seja, o sujeito negro proletário (GUIMARÃES, 2014).

Embora haja influência da teoria de Franz Boas em relação à separação de raça (natureza) e cultura em produções como as de Gilberto Freyre, o abandono da teoria das raças não acompanhado de um movimento crítico sobre as relações de dominação no país - veladas pela ideia de encontro harmonioso, ou miscigenação - faz com que cultura seja mobilizada quase que no mesmo sentido de "raça", ou seja, pelo viés hierárquico presente na fundação da antropologia: a relações entre raça e cultura como uma relação de um para um (HOFBAUER, 2009; GUIMARÃES, 2014).

É na segunda metade do século XX que raça no Brasil ganha outra centralidade. Um dos marcos é o projeto UNESCO, o qual gerou uma série de estudos que apontaram 
disparidades raciais entre negros e brancos no Brasil. Participaram do projeto UNESCO teóricos como Virginia Bicudo, Florestan Fernandes, Roger Bastide, Oracy Nogueira, entre outros. Roger Bastide deu importantes contribuições sobre a dinâmica das relações raciais ao projeto UNESCO, para as quais lançou mão de métodos sociológicos cunhados pela Escola de Chicago (HOFBAUER, 2011).

Foram os estudos da UNESCO que deram notoriedade às desigualdades raciais no Brasil e abriram espaço para pesquisas como as de Michael Hanchard, Nelson do Valle e Silva, Carlos Hasenbalg, entre outros (PINHO, 2008). As críticas de Wacquant e Bourdieu ao trabalho de Michael Hanchard e de outros pesquisadores que abordam relações raciais na América Latina e no Brasil, tomando este último caso por exemplo, são insuficientes quando consideramos esse contexto de produção e realidade.

Entre os anos de 1970 e 1980 destacam-se produções nos campos denominados “pós-coloniais" e "estudos culturais". De acordo com Sérgio Costa (2005), a diferença entre os estudos culturais e pós-coloniais é apenas temporal, pois ambos têm como foco as mesmas questões: identidade, diferença, cultura, racismo, etnicidade, gênero etc.

Os estudos pós-coloniais estabeleceram críticas aos paradigmas da modernidade, oferecendo uma crítica à ideia de identidade. O objetivo central dessa corrente teórica foi denunciar e desconstruir os modelos binários que opõem Ocidente ao resto do mundo e que sustentam a lógica colonial "dominador-dominado" (COSTA, 2005).

Orientalismo (1978) de Edward Said é considerada a obra fundadora dos estudos pós-coloniais. Neste livro, o autor apresenta como a noção/imagem de Oriente foi construída pelo Ocidente como o "Outro" e foi importante para a consolidação da imagem da sociedade ocidental para ela mesma, ou seja, seu "mito de superioridade". Para Said, é necessária a desconstrução das oposições binárias estabelecidas neste processo, considerando que sustentam relações de poder, aprisionaram o Oriente em estereótipos, estigmas e identidades fixas inferiorizadas. A saída não se dá pelo paradigma colonial, mas pelo rompimento com o mesmo.

Embora Said seja considerado o autor da obra que funda os estudos pós-coloniais, foi Frantz Fanon (1925-1961) quem deu origem à obra que marcaria os futuros estudos pós-coloniais, Pele Negra, Máscaras Brancas (1952).

Nesta obra, o autor afirma que, como consequência do colonialismo, o homem negro não é um homem, é um homem negro, pois este teve a sua humanidade roubada a favor de uma dita "superioridade dos homens brancos". O negro, além de ter que adotar aquilo que o branco lhe infligiu, é cercado de nos livros, filmes sobre aquilo que se vê 
como ser negro, estereótipos que alimentam o desejo de não ser negro, por terem seus corpos marcados pela cor a qual são atribuídos juízos depreciativos.

Tanto o negro como o branco, para o autor, são sujeitos alienados, sendo os primeiros mistificados nessa alienação e os segundos mistificados e mistificadores. Os negros são mistificados porque foi construída sobre eles uma imagem de subalterno, e os brancos são mistificadores porque eles, como colonizadores, construíram sobre si uma imagem de superioridade em relação ao negro e é mistificado enquanto tal. A alienação encontra-se na crença de que um grupo racializado é superior a outro grupo também racializado. Fanon acredita que a libertação do homem negro se dá pela compreensão das relações raciais entre branco e negro e na desconstrução desse imaginário colonial que não passa de uma "ideologia dos imbecis". Os que ele chama de "imbecis" são produto de uma estrutura econômico-psicológica.

Fanon aponta que o homem não é nada além de humano, e precisa acabar com o narcisismo que o faz se imaginar diferente dos outros. Provar a humanidade de todos os homens seria uma tarefa fácil, mas a preocupação central do autor "é ajudar o negro a se libertar do arsenal de complexos germinados no seio da situação colonial" (Fanon, 1952, p. 44). Há um esforço intelectual e político em busca da desalienação da humanidade defendida por Fanon, este considerado o herói da descolonização. A desalienação consiste na compreensão do homem pelo homem de que as diferenças não determinam superioridade ou inferioridade e que as amarras e impedimentos são construções sociais que precisam ser desmanteladas.

Para os autores pós-coloniais, as lutas anticoloniais clássicas, como o movimento da negritude e o pan-africanismo ocorreram dentro da episteme colonial, através da apropriação e atribuição de novos significados às categorias essenciais, reificando, de certa forma, a dicotomia colonizador-colonizado. Os pós-coloniais exigem outra atitude: a crítica aos operadores de exclusão para a descolonização de nossas mentes.

No entanto, entre os pós-coloniais encontramos um conceito que traz uma outra compreensão sobre os movimentos que buscam a libertação por uma via essencializante, o "essencialismo estratégico", cunhado por Gayatri Chakravorty Spivak e apresentado no livro In Other Worlds: Essays in Cultural Politics. Segundo Spivak (1989), as atitudes que são opostas ao essencialismo se devem a seu acordo com o universalismo, que coloca em primeira instância uma identidade hierarquicamente superior à outra. Aponta que para haver, uma ação política é indispensável mediar em favor de uma essência, observando de perto os artifícios do discurso entre o "eu" e o "outro", a autora aposta no 
"essencialismo estratégico" como uma junção de solidariedade breve que permite a ação de determinados grupos "dominados". Apelando aos estratagemas culturais e históricos comuns, no sentido de construir uma identidade política necessária para a intervenção diante de sua condição social, os grupos criam diferenças essenciais, uma estratégica crítica para não incorrer no erra de naturalizar as diferenças.

Já os estudos culturais, campo fundado por cientistas sociais, é uma corrente interessada no tema da cultura como um espaço de disputa, poder e conflito. A cultura, para esses autores, é entendida como lugar em que os significados e os processos de diferenciação são negociados. A corrente dos estudos culturais procura chamar a atenção para ausência de consensos no campo cultural. Esse grupo de autores pretende entender a formulação das diferenças e das fronteiras inerentes ao processo de globalização, tendo como foco analítico três conceitos básicos: cultura, poder e identidade (HOFBAUER, 2009).

Tomemos aqui dois exemplos dos estudos culturais citados constantemente nos estudos sobre relações raciais no Brasil, Stuart Hall e Paul Gilroy. Para Hall, "raça" é uma construção política e social presente no discurso que organiza um sistema socioeconômico de exploração e exclusão: o racismo. O racismo tem um efeito de naturalização para justificar as diferenças e as desigualdades (HALL, 2003).

Hall (2003) defende que o racismo biológico tem como marcador a cor da pele que acaba se estendendo como "etnicidade" para controlar diferenças culturais e sociais fixando-as como sinônimo de raça. Para o autor, nos anos 1980, houve um declínio do racismo de ordem biológica para a entrada de um racismo cultural. Embora ele se ressignifique, a base é a mesma: a naturalização e fixação de identidades a partir da cor, tradições e origem. A relação entre diferença e natureza, enraizada na ideia de "raça", é transportada para o discurso da etnia. Tanto o discurso de raça como o discurso de etnia acabam por estabelecer uma equivalência entre o natural e o sociocultural. Assim, o racismo biológico e a diferença cultural não compõem dois sistemas distintos, mas fazem parte do registro do racismo, e em muitas vezes os dois discursos estão em jogo simultaneamente. É preciso reconhecer que o "racismo biológico" e a "discriminação cultural" são fenômenos interligados que compartilham de um fundamento comum: a estigmatização do "outro" como mecanismo de inferiorização.

Segundo Gilroy (2007), o discurso sobre a existência de "raças" está saturado pelos avanços científicos e tecnológicos do século XX, e a humanidade ainda não se liberou deste conceito. "Essa revolução biotecnológica exige uma mudança em nosso 
entendimento de 'raça', espécie, corporificação e especificidade humana" (GILROY, 2007, p.39) ao comprovar que nossas diferenças não vão além dos fenótipos e que compomos um mesmo grupo.

Ao mesmo tempo em que os beneficiários da hierarquia racial não renunciam a seus privilégios, as pessoas violentadas por essa hierarquia vêm adotando categorias dos "dominantes" para denunciar e resistir aos lugares de exclusão social que lhe restaram. "Negros e brancos estão presos conjuntamente pelos mecanismos de 'raça' que alienam uns aos outros e amputam sua humanidade comum" (GILROY, 2007, p. 33)

Gilroy argumenta que o processo de exploração histórica e de inferiorização do colonizado geram sobreviventes "acossados pela culpa, vergonha e memórias incertas e dolorosas ao extremo", passado que não pode ser desprezado, porém, defende que temos que "nos livrar disso e encontrar a nós mesmos novamente sem o auxílio de categorias raciais, ou da tradição racial" (GILROY, 2007, p. 37).

Fazendo uma crítica à literatura ocidental sobre identidade, cultura e diferença, tanto os autores dos estudos culturais como os pós-coloniais desconstroem as dicotomias de representação do Ocidente e defendem a não essencialização da diversidade humana. As identidades, diante dessas perspectivas teóricas, são assim tratadas como influência do poder e, vistas sob esse aspecto, se apresentam como uma questão política, o que potencializa a crítica aos modelos binários.

Assim como os estudos culturais e pós-coloniais, os estudos decoloniais têm como foco as consequências do colonialismo e da expansão imperial europeia pelo resto do mundo, pensando categorias, lugares, sujeitos, relações de poder e dominação. No entanto, se as duas primeiras áreas problematizam as categorias e dicotomias apontando para o caminho de desconstrução, onde o processo de libertação não acontecerá dentro do paradigma colonial, a segunda desconstrói o lugar "subalterno" dos sujeitos locais elaborado na relação com o colonizador, ao mesmo tempo que reifica as dicotomias dominador-dominado ao apontar uma alternativa de superação.

Neste sentido, os estudos decoloniais, que emergem na América Latina, lançam mão de um olhar dual, ou seja, há na proposta um inimigo histórico definido, o mundo ocidental e suas formas de dominação e paradigmas. Esses trabalhos traçam criticamente como as relações de dominação têm consequências sobre os povos não ocidentais, mas pouco consideram a participação dos mesmos na dinamização dos Estados coloniais, ou seja, mesmo que os "dominados" estejam em condições desiguais de poder, a correlação de forças e influências quase nunca é abordada como uma via de mão dupla dentro do 
regime colonial. Alguns autores, como Aníbal Quijano, enfatizam as formas de resistência e agência elaboradas pelos povos locais contra regimes de opressão, mas continuam os abordando de forma isolada, como movimentos de fora e não de dentro do sistema.

Conforme Aníbal Quijano (2000), raça é um instrumento de dominação que dá sustentação ao modelo de poder e exploração do capitalismo. Para o autor, não haverá construção de um projeto real de Estado-nação sem pensar a descolonização das estruturas de poder, do imaginário e a democratização da sociedade e do Estado. Este modelo que vivemos, em contextos pós-coloniais onde desigualdades e privilégios do regime colonial se mantêm, é chamado pelo autor de "colonialidade do poder". Na “colonialidade do poder", raça opera como operador ideológico que naturaliza relações desiguais entre brancos e não-brancos, possibilita a dominação e impede $\mathrm{o}$ desenvolvimento de um projeto de Estado-nação que respeite o direito de todos que compõem a sociedade.

Em Global Coloniality and the Decolonial Option (2009), Walter Mignolo e Madlina Tlostanova apresentam uma discussão sobre como os paradigmas da modernidade impedem a superação da colonialidade. Conforme afirmam, a colonialidade perpassa diferentes períodos históricos e regimes políticos, sendo ela um fenômeno global e o lado escondido da modernidade. Essa modernidade, que tanto problematizam no texto, não se propõe a superar a colonialidade - fenômeno que justifica todas as formas de ação da primeira, incluindo as guerras, com o objetivo e eliminar a tradição.

Neste sentido, os autores apontam que o pensamento decolonial e a opção decolonial não podem acontecer dentro da modernidade. Estes são projetos criados por aqueles sujeitos trazidos por Franz Fanon em Os condenados da terra: humilhados, desvalorizados, desconsiderados etc., ou seja, aqueles que lidam com a ferida colonial. Esse pensamento assume os problemas trazidos por movimentos radicais que se organizam por meio do conhecimento que não é produzido na academia, mas a partir das experiências de vida que a produzem.

Para eles não existe proposta de mudança dentro da modernidade, diferente do que Paul Gilroy traz ao afirmar que os africanos retirados de sua terra natal para trabalhar nas Américas criam uma contracultura dentro do projeto de modernidade ocidental, o Atlântico Negro (GILROY, 2001). O Atlântico Negro é uma forma de demonstrar como africanos não foram passivos dentro do projeto de expansão imperial do ocidente, mas 
que dinamizaram esse projeto e colocavam suas questões, mesmo em condições desiguais de poder.

\section{Posicionando os saberes}

Dentre as áreas abordadas, temos uma antropologia que narra a diferença, mas pouco se posiciona sobre as desigualdades produzidas por elas. Temos uma sociologia que leva a ideia de raça social a sério a ponto de sair do campo descritivo e analisar, de forma crítica, os impactos da ideia de raça no contexto social. Temos os estudos culturais e pós-coloniais que, longe de fazer algum estudo focado, contribuem com uma leitura crítica mais ampla sobre como as dicotomias dominador-dominado reificam as estratégias de dominação, optando pelo caminho da desmistificação. Temos os estudos decoloniais que problematizam as relações de poder de forma similar ao que foi feito pela sociologia e estudos pós-coloniais, mas que pensam a mudança a partir daquilo que é produzido localmente e esquecem da participação de sujeitos locais, mesmo que de forma marginal, naquilo que foi construído globalmente.

Com todas as suas contribuições, no que pese a desconstrução de ideologias e sistemas hierarquizantes no plano analítico, a antropologia não pode ser o campo de conhecimento a serviço da deslegitimização de grupos que lutam contra as desigualdades frente às quais ela mesma, em muitos momentos, atua somente na chave nas problematizações e não se posiciona. Neste sentido, considero que a sociologia trouxe muito mais contribuições para o debate sobre as iniquidades sociais ao adotar a ideia de diferença não só para falar sobre diversidade, mas sobre as desigualdades por ela produzidas, e ao apontar formas de superá-las.

Já os estudos pós-coloniais e culturais, embora abordem culturas e identidades com especial preocupação sobre relações de poder e categorias que prendem sujeitos coletivos perpetuando diversas formas de dominação, pouco se debruçam em estudos locais que dialoguem com grupos específicos. Isso faz com que suas desconstruções sejam, em muitos momentos, utilizadas para deslegitimar as ressignificações de sujeitos e movimentos produzidas em diferentes contextos. Alguns intelectuais usariam esses campos de estudos para dizer que grupos locais que atuam contra as desigualdades estariam sendo "essencialistas" em suas reivindicações. A ideia de essencialismo estratégico, cunhada por Spivak e apresentada acima, poderia ser uma saída conceitual, mas ela existe porque Spivak é uma feminista que a elaborou falando do movimento de 
mulheres, lugar que a fez buscar uma compreensão não só epistemológica, mas também política. Neste sentido, como aponta Hofbauer (2011), os estudos culturais e pós-coloniais também têm algo para aprender com a antropologia, o estudo focalizado que possibilidade a escuta de narrativas locais.

Para Sérgio Costa (2005), a crítica dos estudos pós-coloniais e culturais tem como foco a teoria da modernização, o que os aproxima de alguns trabalhos que já vinham sendo desenvolvidos por cientistas sociais. No entanto, o autor nos chama a atenção para o fato de que esses estudos, ao parar na crítica e desconstrução de categorias essenciais, acabam por deslegitimar áreas que têm se debruçado sobre a ideia de desenvolvimento e desigualdades.

Já os estudos decoloniais poderiam ter uma proximidade com a sociologia se não negassem a participação dos "subalternizados" na modernidade. Domingues (2009) defende que há necessidade de avaliar as contradições e ambivalências dentro dos sistemas. Grupos fazem parte da modernidade e agem dentro dela sem deixar de perceber seu lugar marginal, por isso lutam contra as formas de exclusão de maneiras diversas. Há uma combinação dos termos ocidentais com as políticas se representação, ou seja, instituições modernas e comunidades tradicionais estão em conexão.

Conforme Domingues (2009), é preciso compreender as comunidades tradicionais - os "locais" - como sujeitos que agem e constroem na modernidade. Para o autor, quando Mignolo apresenta a modernidade como um projeto do Ocidente e nega a participação da periferia na mesma, reforça a lógica de tendências dominantes por ignorar os enunciados e movimentos que sujeitos subalternizados produzem dentro dela. Um exemplo disso, no que concerne à Revolução Francesa e à Revolução Haitiana, seria o fato de que nem os franceses aceitam que os haitianos fazem parte de uma modernidade, nem Mignolo.

Há novas identidades e movimentos em emergência na América Latina que produzem narrativas que, conforme o autor, devem ser consideradas na opção decolonial apresentada por Mignolo e Tlostanova, a exemplo dos movimentos de trabalhadores, meio ambiente, mulheres, raciais etc. São estes movimentos modernizantes que se desenvolvem a partir da modernidade. A opção decolonial de Mignolo nos ajuda a reorientar o pensamento, mas nós não podemos jogar todo o resto fora. Para ampliar a percepção sobre isso, Domingues propõe um diálogo necessário com as ciências sociais e os acúmulos da sociologia sobre o tema "modernidade". 


\subsection{Neocolonização: esquemas de interferências e as possibilidades de efetivação}

Para sustar a interferência estrangeira nos assuntos das nações em desenvolvimento é preciso estudar, compreender, revelar e combater ativamente o neocolonialismo sob qualquer disfarce que este possa usar. Pois os métodos dos neocoloniais são uteis e variados. Operam não apenas no campo econômico, mas também nas esferas públicas, religiosa, ideológica e cultural.

- Kwame N'Krumah (1967 p. 281)

Esta epígrafe é do presidente deposto de Gana, Kwame N'Krumah e autor do livro: Neocolonialismo: Último Estágio do Imperialismo. Ele faz uma radiografia do continente africano e também uma denúncia dos males causados pelo imperialismo em desenvolvimento. $\mathrm{O}$ autor mostra as faces e fases do neocolonialismo e aponta que é possível combatê-lo.

N'Krumah (1967) é considerado um dos primeiros autores a tratar do neocolonialismo. Ele foi deposto da presidência de Gana pelos militares, refugiou-se na República Árabe Unida juntamente com sua família e foram proibidos de regressarem ao seu país. As razões apresentadas pelo povo ganense foram três: ele foi considerado um ditador; foi acusado de corrupção; e foi acusado de fomentar a subversão da África. Na abertura do livro, N'Krumah faz uma denúncia do neocolonialismo e uma defesa de si quanto as acusações:

A primeira acusação fica bastante prejudicada em virtude de ser formulada por militares que acabavam de implantar um regime francamente ditatorial em Gana. Quanto às acusações de corrupção e de subversão, sabemos hoje muito bem que eles servem frequentemente a interesses antiprogressistas, às forças e alienação, que exploram o moralismo ingênuo e os anseios de ordem de certos setores minoritários, porém influentes das populações dos países subdesenvolvidos (N'KRUMAH, 1967, p.2).

Guardadas as devidas proporções de tempo, espaço e acusações, N'Krumah, por ser um dos pioneiros a escrever sobre o neocolonialismo, apresenta reflexões importantes para esta pesquisa, principalmente, para conjeturarmos sobre a ideia de construção de uma "nova" nação por meio da educação pública preconizada por grandes grupos empresariais do Brasil e fora dele, como vimos no capítulo anterior, e para ajustar o ponto nevrálgico desta tese, qual seja: indagar sobre as novas formas de colonização, aqui, via educação básica e pública. 
Para o autor, o neocolonialismo não é um sinal de força do imperialismo, mas seu último e abominável estertor. Não tem capacidade de dominar por muito tempo, pois seus métodos não permitem. Enuncia que o imperialismo dissimula que a independência é algo essencial e que ele respeita, no entanto, o que ele mais tenta é tomá-la de volta.

N'Krumah (1967) aponta alguns métodos que o neocolonialismo utiliza para dominar os países subdesenvolvidos, o foco do autor é pensar no continente africano, em alguns países asiáticos e na América Latina. Nessas análises, os Estados Unidos se comportam como o maior dos imperialistas.

$\mathrm{O}$ autor defende que o imperialismo, ao se deparar com os militantes das antigas colônias, principalmente da África, da América Latina e do território dos Caraíbas, muda de estratégia. Ele passa a se apresentar como um apoiador da "independência dos seus súditos", preza pela liberdade e lhes oferece ajuda para seu desenvolvimento, entretanto, cria inúmeras formas modernas para manter o controle como fazia no colonialismo. N'Krumah aponta, portanto, que essa soma de táticas veio a ser conhecida como neocolonialismo.

Uma delas é a que o autor chama de "Governo Invisível”, que é formada por pessoas de diferentes órgãos como os investidores bilionários de Wall Street, o Pentágono e outros serviços de informação. O “Governo Invisível” é um agrupamento amorfo constituído por indivíduos tirados do governo visível, como agentes da Segurança Nacional, membros da Comissão de Energia Atômica. "O Governo Invisível inclui também muitas outras unidades e agências, assim como indivíduos, que aparentam ser parte normal do governo convencional" (N'KRUMAH, 1967, p.282). Este conjunto de agências formam o parelho que orientam milhares de cidadãos norte-americanos fazendo com que eles apoiem as políticas externas dos Estados Unidos pela persuasão ou pela força.

Este governo teve início por conta de dois fatores: o fim da Segunda Guerra Mundial e a posição de potência mundial com os desafios que o comunismo soviético conferia. Com isso, o mecanismo neocolonialista passou a dirigir, segundo o autor, outras organizações ocidentais de informação. O objetivo central foi o de manter o colonialismo, pregando, ao mesmo tempo, a independência dos Estados nacionais. O favorecimento econômico, o monopólio do mercado mundial, as altas taxas de juros para as nações devedoras e seu empobrecimento: 
Outra armadilha neocolonial na frente econômica veio a ser conhecida como "ajuda multilateral" através de organizações internacionais: o Fundo Monetário Internacional, o Banco Internacional de Reconstrução e desenvolvimento (conhecido como Banco Mundial), Corporação Internacional de Finanças, são exemplos todos eles, significativamente, tendo o capital norte-americano como seu maior financiador (N'KRUMAH, 1967, p.285).

N’Krumah também fala de um "Comércio Invisível” aplicado na indústria, no comércio e na agricultura. Ele vem simulado de ajuda para os países subdesenvolvidos, no entanto, essa ajuda lhe propicia uma intromissão nas finanças internas destes países. Junto a isso, produção cultural também teve um papel importante para o neocolonialismo. As histórias do cinema de Hollywood embrenharam-se no imaginário dos indivíduos com uma propaganda incessante antissocialista, pessoas negras em papel de vilão e bancas como agentes federais da CIA, heróis brancos e bandidos latinos. A ficção de Hollywood se encarregou, em grande parte, da neocolonização cultural:

Mesmo as histórias de cinema da fabulosa Hollywood são viciadas. Basta ouvir os aplausos de uma audiência africana aos heróis de Hollywood massacrando índios peles-vermelhas ou asiáticos para compreender a eficiência dessa arma. Pois nos continentes em desenvolvimento, onde a herança colonialista deixou uma grande maioria ainda analfabeta, até a criança mais nova aprende a mensagem contida nas histórias de sangue e violência saídas da Califórnia (N'KRUMAH, 1967, p. 289).

Contudo, o autor enuncia que é possível enfrentar e destruir o neocolonialismo. Aponta que suas táticas são antigas, resumem-se me dividir e dominar, com isso, fica nítido que a unidade é a primeira condição para destruí-lo.

Para o autor, era preciso haver uma união geral entre os governos africanos. As organizações afro-asiáticas já estavam fortalecidas e era hora de buscar a adesão dos latino-americanos. Também, como estratégia, era preciso encorajar as poucas forças que estavam dentro do mundo imperialista, mas que, no entanto, apoiavam o anticolonialismo.

Para a execução desse projeto, era preciso apoiar todos os planos nacionais com o objetivo de fortalecer as noções independentes, necessariamente havendo alinhamento político e, fundamentalmente, era preciso promover um escurecimento ideológico a toda população, militantes, anti-imperialistas e anticoloniais, pois, segundo o autor, somente essa massa pode sustentar ou interromper revoluções: 
Com a maior rapidez, o neocolonialismo precisa ser analisado em termos simples e claros para o pleno entendimento da massa, pelas organizações nascentes dos povos africanos. A Federação dos Sindicatos de Toda a África (AATUF) já iniciou um movimento nesse sentido, enquanto o Movimento da Juventude Pan-Africano, as mulheres, jornalistas, fazendeiros e outros não estão muito atrás. Apoiadas em clareza ideológica, essas organizações, estreitamente ligadas aos partidos governantes onde as forças de libertação estão no poder, comprovarão que o neocolonialismo é o sintoma da fraqueza do imperialismo e que pode ser derrotado, pois no final das contas é o chamado homem comum, com as costas curvadas, explorado, mal nutrido, o ensanguentado lutador pela independência que decide. E Ele invariavelmente, decide a favor da liberdade (N'KRUMAH, 1967, p. 299).

Embora as críticas do autor estejam centradas no contexto norte-americano, ele nos apresenta uma visão adequada para pensarmos os possíveis mecanismos de manipulação do neocolonialismo frente às questões em foco nesta pesquisa. As empreitadas neocoloniais, penso aqui, advinda dos grandes grupos empresariais, tendo a educação como eixo principal, têm consonância com as questões trazidas nos capítulos anteriores e a forma que o sistema educacional vem se remodelando no Brasil. Conforme apresentei, temos grandes grupos corporativos que criam instituições que oferecem gratuitamente cursos e formações para as secretarias de educação de municípios brasileiros, com uma linguagem empresarial e homogênea. Esses grupos são constituídos e dirigidos pelas e pelos empresários mais ricos do país e detêm boa parte do poder econômico e político.

O sistema educacional, principalmente no que tange à Educação Básica, abriu portas e janelas para a globalização, aderindo aos pressupostos e regras que regem esse sistema, tornando-se, também, cúmplice dos projetos e ideias dos grandes grupos capitalistas nacionais e internacionais. Podemos perguntar: por que a educação pública e básica foi a escolhida para este pretenso projeto de uma "nova" nação? Minha hipótese é que, com a "universalização" do ensino, é nas escolas públicas que se concentra o maior número de pessoas, estudantes, e todas as profissionais da educação. O Instituto Nacional de Estudos e Pesquisas Educacionais Anísio Teixeira (INEP) divulgou que, em 2018, havia cerca de 5,1 milhões de alunos matriculados nas escolas municipais (42;8\%), 5 milhões na rede estadual (41,9\%), e apenas $15,1 \%$ dos alunos nas redes privadas, incluindo o ensino Fundamental I e II e o Ensino Médio. As escolas federais totalizaram apenas $0,2 \%$ e matrículas em 2018. 
Em entrevistas para jornais, revistas e em grandes reuniões corporativas/formativas, alguns membros dos grupos empresariais supracitados, declaram abertamente que o intuito das suas instituições é, por meio da educação, colaborar para que o Brasil se torne uma "nova" nação, que saia da precariedade e alcance os mesmos níveis que os países mais desenvolvidos.

Num dado momento da pesquisa, senti a necessidade de me certificar que as declarações dessas "lideranças", que eu li e ouvi tantas vezes por conta da minha inserção em projetos educacionais, eram apenas proforma, uma maneira despretensiosa de falar e pensar a nação. Na busca por sanar minhas dúvidas, conversei com uma pessoa que compunha um dos quadros mais altos de uma instituição, gerente de projetos, criada e financiada por uma das maiores mineradoras do Brasil. Nossa conversa, via áudios de WhatsApp, veio com seu consentimento de que eu poderia publicizar seu depoimento, mas de maneira alguma revelar seu nome. Minha principal pergunta foi: por que, na instituição que em que ela trabalhava, entre todos os projetos, o investimento maior de recursos era nos que incidem na educação pública e com quais pretensões? Segue a resposta.

Honestamente, eu acho bem importante os projetos que desenvolvemos aqui. A educação sempre foi nosso foco, a instituição foi criada para isso. No começo, nossa atenção estava toda voltada para os estudantes, principalmente do Ensino Médio. Tínhamos projetos para inseri-los de forma mais qualificada no mercado de trabalho, mas, com o passar do tempo, vimos que não estávamos tendo bons resultados, tem uma mentalidade primária dos jovens da escola pública que, infelizmente, não deixa que eles prosperem, se firmem em bons empregos. Falta postura, garra, entende? Mas a culpa ou responsabilidade não é deles, é da pobreza mesmo e do ensino precário. Não dá pra negar que a maioria das escolas públicas do Brasil não ensinam nada. Os analfabetos funcionais não são lenda, infelizmente. Bom, mais ou menos uns sete anos atrás, começamos os preparativos para reformular nossos projetos, mas não sabíamos ainda, qual o caminho que iríamos tomar. Então, começamos a promover reuniões com especialistas em educação e com outras instituições de ponta que trabalhavam com educação e com projetos inovadores. Nos filiamos ao [Sapo Cururu], lá nos encontramos. Entendemos, por exemplo, que, para haver uma mudança verdadeira no Brasil, precisamos cuidar da Educação Básica, com maior foco no Fundamental I e II. Aí, começamos a articular, viajar pelo Brasil conhecendo projetos e vimos que muitas instituições tinham seus projetos focados nos 
professores, na gestão escolar e educacional. Entendemos que, para atingir os alunos, precisamos, primeiro, formar os professores. Mudar a concepção deles, atualizá-los, incentivá-los, sabe? Então, resolvemos focar um dos nossos projetos na gestão escolar. Contratamos especialista em projetos, vimos várias experiências e criamos o nosso. Um dos nossos objetivos era sair dos grandes centros e olhar para as regiões mais isoladas, no sentido, de serem mais distantes, com menos recursos, enfim, as regiões que o poder público não olha. Ainda quando estávamos criando o primeiro projeto, vimos que as nossas ideias, as nossas intenções, que na verdade não eram só nossas, não saíram da nossa cabeça do nada, mas eram as intenções da direção geral e dos investidores, do instituto, ou seja, da empresa, que tudo estava em consonância com as outras instituições dessa rede maravilhosa que o [Sapo-Cururu] criou. (...) Nossa intensão é ajudar essa população, ajudar mesmo! Transformar a mentalidade não só das pessoas que só tem a educação pública, mas a mentalidade do brasileiro em geral. A gente sabe que a educação pública está falida há muito tempo. Na verdade, ela já começou falida, mas, com a ampliação do ensino, que foi muito boa, as coisas só pioraram, ladeira abaixo, um caos. Não adianta os municípios e estados terem dinheiro pra educação, se o investimento não está sendo feito de forma correta, mesmo em São Paulo, por exemplo, que o ensino ainda é considerado um dos melhores. A gente está num tempo e a educação paralisou, ficou lá na década de 70, quando tínhamos outra situação e eu falo, principalmente em relação às disciplinas obrigatórias, a forma que é ensinado, não só da precariedade das estruturas físicas das escolas, que não dá para negar, é um grande problema. Teve um grande programa do governo federal que construiu salas de informática em muitas escolas, mas, olha só, encheram as salas de computadores novos, mas com sistemas inadequados, ultrapassados. Largaram lá, sem manutenção, sem internet e sem professores qualificados para fazer um bom uso desse recurso. A máxima GLS (giz, louça e saliva) é o que ainda impera! Mas isso está mudando! Estamos empenhados em mudar essa situação. [perguntei qual era o caminho da mudança, o que eles pretendiam e por que os empresários que compõem o Sapo-Cururu assumiram essa tarefa, que é do poder público] (...) Bom, não tem outro caminho a não ser começar tudo de novo, praticamente do zero, pegar essa nova geração, dar uma boa educação para termos um outro país no futuro. Treinar os professores, e não adianta vir com a ideia de reciclagem, tem que começar do zero mesmo. Atualizar os currículos dos municípios de acordo com a nova BNCC [Base Nacional Comum Curricular], mas também com o mundo globalizado, trazer para dentro da escola a mesma gestão que temos nas 
empresas, por exemplo. Desenvolver as competências de cada ator que está na direção, incluindo os Secretários de Educação. Trazer disciplinas que, de fato, serão úteis para o mundo do trabalho, por exemplo, finanças e cursos técnicos para que os estudantes, assim que se formarem, ou até antes, já consigam bons empregos nas fábricas, nas indústrias. Essa é a nossa intenção, e o caminho é esse, atingir a gestão, mudar a mentalidade para que possamos com o apoio deles, mudar o ensino do Brasil. (..) Bom, o Brasil não deu certo! O Estado brasileiro não deu conta de promover coisas básicas que uma nação precisa, não só na educação, mas na saúde e na segurança. Olha como estamos! A Segurança Pública não dá conta da violência, o SUS muito menos. Há anos o Brasil fica dando um jeitinho. Entra e sai governo e as coisas só pioram. Os movimentos que se dizem sociais, com bastante aspas, só tumultuam e não levam a população para lugar nenhum! Entendemos que, agora, a obrigação de construir um país melhor é das pessoas que têm mais capacidade financeira, intelectual, que têm mais acesso ao que acontece no mundo. As parcerias público-privadas são isso, um desejo das empresas privadas em colaborar para formar uma nova nação. Por isso, Valéria, quando você me falou das entrevistas e tal, eu fiquei pensativa, mas é isso mesmo. Hoje, quem tem mais condições de melhorar o Brasil são os empresários mesmo e acho, de fato, que é uma obrigação deles. (...) temos que mudar o jogo, as mentalidades, ir pra cima, progredir, sabe? Temos que evoluir e deixar de ser, de uma vez por todas um Brasil Tupiniquim.

O trecho acima explicita as pretensões e ações da iniciativa privada no Brasil, para construir uma "nova" nação, baseada, de distintas maneiras, na linguagem e com tecnologias empresariais. Como vimos no Capítulo 3, dezenas de empresas e empresários estão pautando projetos para educação com a anuência dos governos estaduais, municipais e federais. A conversa acima e todas as sinuosidades apresentas até aqui, asseguram minha hipótese de que as parcerias público-privadas são um projeto político de nação, que finge ser despretensioso, no entanto, segue numa postura de retirar e de assumir o papel do Estado nas instituições mais importantes e essenciais para o desenvolvimento social de qualquer país. Adoto a teoria de N'Krumah quando ele diz que o imperialismo lançou sua última cartada, ou seja, o neocolonialismo que se transveste de maneiras distintas para dominar e colonizar corpos, mentes e as relações sociais. É uma restruturação das práticas coloniais disfarçadas de "ajuda", "apoio" para resolver as questões mais pungentes do Estado nacional. 
Ana Mônica Henrique Lopes (2011), ao tratar o neocolonialismo em África, nos provoca a pensar se o neo realmente significa algo novo, quem ele subjuga e a quem interessa. Ela aponta que é preciso pensarmos na intencionalidade dos signos, dos significados e definições discursivas para traçarmos caminhos seguros de interpretações:

O primeiro ponto a ser pensado para evitar desvios históricos e temporais é determinar que estamos falando do neocolonialismo da segunda metade do século XX, pois a mesma expressão é ou foi utilizada para definir as ações dos Estados europeus em África a partir das últimas décadas do XIX (LOPES, 2011, p.3).

Lopes enuncia que, à época, o conceito de imperialismo não dava conta das práticas utilizadas em países africanos, seus modus operandi, não sustentavam as novas formas de administração e exclusão das populações em outros territórios que não dos territórios da América que passaram por um sistema colonial singular. Foi necessário ressignificar o conceito.

A autora aponta ainda que o sistema capitalista submergiu sua identidade fixa, assim, as leituras reguladas na chave do neocolonialismo criaram outras expressões como colonialismo do século XIX, identificando o neocolonialismo como um sistema atualizado do capitalismo no século XX. Junto a isso, democracia virou sinônimo de Ocidente, sem nenhum respaldo geográfico ou cultural, criando e organizando imagens discursivas de oposições como Ocidente e Oriente, liberdade e opressão. O neocolonialismo cria condições objetivas para todo esse processo.

\footnotetext{
Enquanto o neocolonialismo passa a ser identificado com os processos decorrentes das atividades econômicas internacionais e dos acordos bilaterais que interferem na autonomia dos recém Estado independentes da África. Essas atividades têm sido desenvolvidas por organismos internacionais de regulação econômica ou financeira. FMI, BIRD, AID, CFI, MIGA. CIADI- por interferência da ONU e suas agências em questões humanitárias ou bélicas, por alianças políticas governamentais e organizações não governamentais (LOPES, 2011, p.13).
}

Aderindo às questões colocadas, inclino-me a pensar que, de fato, o neocolonialismo é uma forma de perpetuar o colonialismo com "novos colonizados" atuando com múltiplas facetas, a educação é uma delas. 


\subsection{Neocolonialismo e Educação: nomear é preciso, mas nem sempre é visível. O cotidiano escolar em Laranjeiras}

Todo amanhã se cria num ontem, através do hoje. Temos de saber o que fomos, para saber o que seremos.

- Paulo Freire

O cotidiano escolar de Laranjeiras não é muito diferente de outros que conheci. As regras, as normas, as impaciências das professoras, a bagunça e a desorganização organizada das e dos estudantes acontecem a todo vapor.

No período que frequentei as escolas, uma me chamou a atenção por ter uma rotina um pouco diferente. Foi a escola da Mussuca, da comunidade da Mussuca ou do Quilombo da Mussuca. Essa escola reservava horários em alguns dias da semana para que os alunos ensaiassem a Dança de São Gonçalo, expressão cultural prestigiada daquela comunidade. Esse tempo de ensaio era chamado de momento cultural. Quem dançava e tocava eram os "meninos", pois, como vimos, na Dança de São Gonçalo, os "homens" dançam vestidos de "mulheres", fazendo uma referência às prostitutas do cais do porto desde o século XVIII, quando os portugueses introduziram no Brasil os festejos em homenagem ao santo.

A comunidade escolar participava dos ensaios, as pessoas assistiam, davam palpites, riam dos mais novos, opinavam sobre a atuação das estudantes, cujo papel, era, além de ajudá-los com os preparativos, zombar da performatividade feminina ali encenada. Um ambiente escolar tumultuado, repleto de questões estruturais, porém, dava para perceber que aquela escola e todas as pessoas que ali frequentavam utilizavam-se do afeto como um expediente comum e de organização.

Durante as entrevistas com as gestoras, algumas frases me saltaram os ouvidos e olhos, dizendo respeito a como elas, apesar de todas as questões, lidavam com estudantes, professoras e funcionárias. Contavam sempre com o diálogo afetivo para dar conta do cotidiano que, em muitos momentos, era estressante. Isso, não era somente porque todos passavam parte de suas vidas junto naquele espaço, mas porque, além do ambiente escolar, das relações de trabalho, ensino e aprendizagem, as ligações de parentesco, de vizinhança e de trocas comerciais, envolviam essas laranjeirenses.

Eu estudei na Zizinha [referindo-se à Escola Estadual Professora Zizinha Guimarães, localizada no centro histórico da cidade, cujo o nome homenageia a primeira mulher 
negra de Laranjeiras a se tornar professora e dedicou a sua vida à educação]. Na época, era a única escola que tinha aqui. Tem algumas gestoras que vieram de fora, ou que não foram criadas aqui. Eu sim! Conheço todo mundo, tem pessoas que já foram meus alunos e hoje os filhos deles estudam na minha escola. A gente dá de cara com todo mundo, cidade pequena, a gente se conhece, mesmo que não converse, cumprimente (...), mas também tem muita fofoca. Se vocêfaz coisas boas, ninguém fala, só olham as coisas que a gente faz que não são, na opinião deles, boas. Por isso, a gente tem que ter muito cuidado com o que fala, como trata as pessoas e por aí vai (...). Eu sou da opinião que tem que tratar todo mundo bem, é aluno, professor, as merendeiras, a gente tá sempre junto, então... (Laudelina de Campos).

As gestoras prezam pela boa convivência e, como Laudelina de Campos, outras têm relatos parecidos quando o assunto é o cotidiano escolar: "a gente passa por poucas e boas aqui na cidade, não é fácil, tem alunos que vêm dos povoados, chegam cansados e com fome, tem que tratar bem, com carinho. São bagunceiros? Sim, são! Mas fazer o que?” (Anastácia).

Nas entrevistas que conduzi, perguntei a elas se os projetos da Secretaria de Educação, como aquele ciclo formativo, haviam provocado alguma mudança ou interferência do cotidiano das escolas. Obtive respostas diferentes a que, naquele momento, não dei a devida importância. No decorrer da escrita da tese, no entanto, recuperei nossos diálogos e percebi o quanto essas respostas eram significativas para as questões que ora venho apresentando. Vejamos:

Por enquanto ainda não! A gente ainda está num momento de rever tudo, entender direito pra colocar em prática de verdade. Então, na minha opinião, ainda vai demorar um pouco pra ter efeito nos alunos e mesmo nos professores (Laudelina de Campos).

Professora, não vai ter efeito nenhum, poxa! Como eu já havia comentado, esses projetos, principalmente esse último [o projeto que acompanhei] tão fora da nossa realidade! Somos duas gestoras na escola, como é que eles querem que a gente dê conta dessas competências profissionais, que agora tão moda? Pra dar certo, é a gente que tem que dizer o que queremos desenvolver, e não eles, que não conhecem nossa realidade, não conhecem nossas escolas, nosso cotidiano, como você mesma lembrou, a gente tem um cotidiano, uma rotina. Temos problemas, sim! Muitos. Nosso IDEB é baixo, temos 
questões com a aprendizagem, não conseguimos fazer um acompanhamento adequado (...). Eu acho que é isso que eles têm que ver, perguntar pra gente e não ficar ocupando nosso tempo com formações, que só devem dar certo em escolas particulares (Aqualtune).

Eles falam que temos que estar conectadas com as coisas que acontecem no mundo. Sim a gente tá sim! A gente sabe o que tá fazendo e tudo que tá acontecendo, inclusive, como uma das conselheiras falou na última reunião do Conselho Escolar, nós não sabemos qual a intensão deles, mas a gente suspeita! Ninguém dá dinheiro de graça, assim, do nada. Cursos gratuitos, material, (...) bota internet nas escolas e deixa que a gente mesmo, junto com todo mundo, pode decidir o que é melhor pra escola. Agora temos Conselho Escolar. Cada escola tem seu valor, sua cultura, o seu jeito de ser. É isso que eles não veem, ou não querem, não sei (Tereza de Benguela).

As falas das gestoras revelam um conflito entre seus afazeres cotidianos e a imposição de projetos advindos das parcerias público-privadas na educação do município. Já tínhamos visto esta contenda no capítulo anterior, entretanto, quero chamar a atenção para dois pontos de análise. (1) As gestoras apresentam críticas contundentes a esses projetos formativos. Desconfiam da intencionalidade das parcerias e percebem nitidamente que o que está sendo oferecido não encontra consonância com o cotidiano das escolas e nem com as precariedades que o município enfrenta, por exemplo, a insuficiência de tecnologias. Além disso, fica subentendido nos discursos, que elas percebem algum tipo de manipulação ou de interesses particulares das empresas para com o município. (2) Apesar das gestoras serem obrigadas a participar dos ciclos formativos, a implementação dos projetos na base encontra resistências. Elas estão no enfrentamento constante daquilo que julgam ser inconveniente e sem propósitos, em relação ao que elas acreditam ser importante para a educação do município.

Mesmo que não tenha sido nomeado, atento-me para essas críticas enquanto atualizações locais do neocolonialismo, suas formas de atuação e resistências a ele. Insisto na compreensão, a partir do estudo de caso em Laranjeiras, que os projetos das parcerias público-privadas na educação do município, são uma das formas de atuação neocolonial. Laranjeiras, assim como outras centenas de municípios, está na mira, na rota e construção de uma "nova" nação por meio da educação promovida por grandes grupos empresariais. 
Lutz e White (1986), ao analisar as políticas contemporâneas apontam que o discurso cria a experiência ao mesmo tempo em que é produzido em contextos específicos de relações de poder.

Deste modo, mais do que tratar um discurso como meio de expressão de diferentes sentimentos, ele deve ser analisado enquanto um conjunto de atos pragmáticos e performativos que comunicam tanto sobre as emoções como sobre outros aspectos variados, como as relações de gênero, raça, classe e nação.

"É na encruzilhada das contradições que as estratégias de mudanças podem ser encontradas" (McCLINTOCK, 2010, p.36). 


\section{Ponto de Chegada. Considerações Finais}

Nem sempre chegar significa finalizar. Acredito ser possível chegar e, logo em seguida, partir. Talvez seja isso que esta tese propõe: entrar na embarcação da chegada e da partida, a possibilidade de trilhar novos caminhos de pesquisa, análises e interpretações. As considerações finais se constituem, também, como um ponto de partida para o aprofundamento das questões expostas nesta tese.

Para abancar esse ponto de chegada, retomo aqui a hipótese e o objetivo deste trabalho. As parcerias público-privadas estão cada vez mais frequentes em diferentes setores públicos, inclusive na esfera educacional. O município de Laranjeiras em Sergipe, especificamente o sistema de ensino, estava e está vivenciando esse processo. Tratava-se, no caso que acompanhei, de um projeto que objetiva oferecer formações para a gestão escolar e educacional do município. O projeto foi organizado e implementado por uma instituição financiada por um dos grandes grupos empresariais dos Brasil, que tem como propósito manifesto melhorar a qualidade da educação por meio de formações que auxiliam as e os profissionais de educação a desenvolver suas competências profissionais. Uma intervenção sem consulta prévia e planejamento coletivo, que ocasionou conflitos, desconfortos e desconfianças em relação aos verdadeiros propósitos do projeto e a eficácia das formações. Objetivei nesta tese analisar se a intervenção de projetos da parceria público-privada na educação pública e básica de Laranjeiras estaria edificando um novo modelo de colonização pela educação. Por meio do trabalho de campo, pesquisei se haveria a probabilidade de concretização deste empreendimento.

Iniciei esta pesquisa trazendo uma reflexão sobre tempos e temporalidades, uma perspectiva que as interlocutoras do meu campo trouxeram ao longo do trabalho. Esse tempo, que é cronológico e linear, simultaneamente, se apresenta num espaço onde as temporalidades se confrontam, se conciliam e prosseguem.

Os caminhos percorridos trouxeram importantes questões, tanto sobre como as gestoras escolares percebem e analisam os projetos das parcerias, quanto as intencionalidades de grupos empresariais em relação à educação pública, com o consentimento, em alguma medida, do poder público.

A anuência do poder público, como vimos no Capítulo 2, vem da sua entrada e ligação com o sistema econômico global, ou seja, sua aderência à globalização e suas decorrências. Trata-se de uma nova forma de orientar o sistema de ensino brasileiro, utilizando de prerrogativas capitalistas e empresariais, que, em alguma medida, tomaram 
de assalto tanto as diretrizes educacionais como os currículos. Também foi possível averiguar que as instituições que se propõem a "colaborar" com a melhoria da educação pública são formadas e financiadas por uma parcela dos empresários, economicamente mais ricos do país.

No primeiro capítulo, apresentei alguns aspectos de Laranjeiras que julguei serem importantes para os contornos desta tese. Os movimentos culturais e de resistências, os festejos, a geografia, histórica e física, alguns aspectos da vida citadina. Essa Laranjeiras exposta não representa o seu todo, ela é muito mais! Tem outros aspectos admiráveis para apreender. A trilha que tracei foi, por um lado, guiada pelo campo e, por outro, pelas minhas escolhas sobre que Laranjeiras seria relevante apresentar.

Nesse meu percurso pelo campo, a vida profissional das gestoras escolares teve destaque e forneceu significativos contextos para a compreensão de como estão estruturados as escolas e o ensino do município. Os processos que as levaram a serem, primeiramente, professoras e, depois, diretoras e coordenadoras pedagógicas, estão intimamente ligados à maneira como o Brasil se constituiu e permanece estabelecendo as relações de classe, gênero, região e com o racismo estrutural.

Nos discursos das gestoras, mulheres negras, a docência não era a primeira opção de carreira. As escolhas iniciais apresentaram barreiras, quase intransponíveis à época: ser comissária de bordo, quando ainda não existia comissárias negras, ser freira, quando essa possibilidade era restringida a essas mulheres. As barreiras raciais fizeram com que essas mulheres optassem compulsoriamente pela docência, atividade realizada por elas com primor. Hoje, não guardam rancor ou decepção por não realizarem seu primeiro anseio, pelo contrário, o orgulho de serem profissionais da educação é o que impera.

Vimos no Capítulo 3, que, sob a proteção e o consentimento do poder público, principalmente o local, as parcerias público-privadas encontraram um campo fértil para realizar seus ideais, com linguagem, estrutura e tecnologias do modelo empresarial. São oferecidos gratuitamente formações e cursos para a educação dos municípios. Essa parceria se institui num modelo homogêneo, não respeitando as diversidades locais, os anseios da população que será atingida e, muito menos, o compartilhamento de seu desenho e como será colocado em prática, com agentes públicos que, ao mesmo tempo, são os alvos e os implementadores dos projetos.

Especificamente o projeto que acompanhei, ele e seus organizadores o apresentam como essencial para o desenvolvimento qualitativo da educação local. Aumentar o IDEB das escolas e do município foi a principal estratégia discursiva para que o projeto fosse 
aceito pela Prefeitura e pela Secretaria de Educação. No entanto, o tratamento que foi dado à comunidade escolar continha duas inclinações: 1) a população local e a gerência do ensino, inaudivelmente, eram vistas como fora do tempo, atrasadas e sem possibilidades de avanços concretos; 2) o avanço seria garantido por meio de formações, utilizando-se de tecnologias digitais e da linguagem empresarial sobre gestão.

O tempo panóptico, um paradigma visual criado para estimular os anseios do progresso de um determinado grupo social, e o espaço anacrônico, considerado como o lugar do arcaico e distante da modernidade, andaram de mãos dadas nos discursos e nas práticas dos organizadores desta parceria.

Tratou-se de um projeto homogêneo, posto em prática em mais de 100 município do Brasil em diferentes estados, da mesma forma e com a mesma linguagem. Distante da realidade local de Laranjeiras, ele apresentou várias contradições e impasses e se deparou com legítimas barreiras para a sua implementação. Ressalto dois desses impasses que apareceram de maneira mais belicosa nas falas das gestoras: 1) o uso das tecnologias digitais, visto que $60 \%$ do projeto previa a interação via plataforma digital, sendo que a internet no município era escassa e precária; e 2) por não fazer parte das necessidades reais de formação das gestoras, elas não se viam na obrigação e nem com o compromisso em colocar aquele aprendizado em prática no "chão da escola"16.

O objetivo desta tese foi anunciar que as parcerias público-privadas na educação eram, em alguma medida, uma nova forma de colonização. No Prelúdio deste trabalho, me associo às críticas aos estudos pós-coloniais de Anne McClintock. Vale lembrar que aprecio tantos os estudos como os autores considerados pós-coloniais, que são importantes e imprescindíveis para qualquer análise sobre a colonialidade. Usei alguns desses estudos e autores no decorrer dos capítulos. Minhas críticas estão focadas na questão dos tempos e das temporalidades e como, no limite, o pós-colonialismo é pensado, colocando, de certa maneira, o sistema colonial como ponto de início e fim dos da história dos países, entre aqueles que, de um lado, promoveram esse sistema e, de outro, foram subjugados a ele.

Os promotores do sistema colonial, como elucidado no quarto capitulo, não abriram mão da dominação das populações que consideram subdesenvolvidas e mesmo as pós-coloniais. O anseio colonial ainda está em voga, entretanto, não se trata da utilização dos mesmos mecanismos. Eles agora, acredito, estão mais sofisticados, na

\footnotetext{
16 "Chão da escola" é uma das formas como as gestoras se referem ao cotidiano escolar.
} 
medida que seus procedimentos são inaudíveis para uma grande parcela da população, porém, identificados por outra e incluo, aqui, os movimentos sociais e acadêmicos.

Seguindo nesta trilha, compreendo os projetos das parcerias, principalmente, daquele implementado em Laranjeiras, como uma estratégia neocolonial. Afim de obter mentes e corpos subjugados e explorados aos seus ideais, os discursos dos grupos empresariais de formação de uma nova nação por meio da educação não é uma simples evocação vazia, ela é recheada de intenções selecionadas, com propósitos concretos e operantes.

N'Krumah anuncia que o imperialismo não se conformou com a autonomia conquistada pelas ex-colônias. Desta forma, o neocolonialismo, disfarçado de "ajuda" despretensiosa, e lançado mão de diferentes artifícios, é o seu último suspiro. Sendo assim, subscrevo a compreensão de que a parceria público-privada na educação de Laranjeiras é uma estratégia neocolonial e aponto os grandes grupos empresariais que financiam os projetos como pertencentes à horda imperialista.

Entretanto, a concretização desta empreitada neocolonial não será simples ou sem contrastes. Encontrará grandes desafios, resistências e confrontos, assim, como o imperialismo sempre encontrou ao longo dos seus intentos.

Os movimentos sociais que pautam o fim das desigualdades, a inclusão e o respeito à diversidade representam a resistência e podem ser considerados um dos mais fortes inimigos das tecnologias de dominação neocolonial. Junto deles, como vimos, está a oposição das gestoras escolares, agentes do poder público e responsáveis por fazer essa empreitada acontecer. A insatisfação com a maneira compulsória e sem sentido prático com que o projeto da parceria se impôs a elas, além de não saberem, de fato, a sua real intenção, fez com que a gestão escolar de Laranjeiras não acionasse suas vontades, capacidades e poder para garantir a implementação integral do projeto, como previam as instituições promotoras.

A interseccionalidade, já mencionada neste trabalho, também se torna uma barreira considerável que essa estratégia neocolonial terá que ultrapassar. Como vimos, a entendimento em trabalhar marcadores sociais como raça, gênero, sexualidade, classe, região e geração de maneira interseccional, já se faz um ponto imutável e consensual para muitos pesquisadores, grupos de estudos e universidades.

Contudo, é sabido que, de forma geral, os campos de estudos se constituem a partir dos movimentos que a sociedade realiza. Assim, o que se estuda e como estuda, acontece, 
primordialmente, na prática, nas experiências vividas cotidianamente. As demandas por esses estudos, muitas vezes, vêm dos movimentos sociais de diferentes segmentações.

Finalizo proferindo que, embora os projetos das parcerias público-privadas, sejam, nestas medidas, uma estratégia importante do neocolonialismo no Brasil, analiso que esse processo, mesmo atuante, vai encontrar obstáculos graúdos, fortes e contundentes que, não sem luta, farão frente a esse processo. Enuncio que, nesta guerra, várias serão as batalhas e o revezamento nas trincheiras.

A mitologia Ioruba conta que a terra, Ilê Aiyê, era formada somente por água. Obatalá sentiu vontade de povoá-la, então, jogou um punhado de areia na terra e uma galinha se encarregou de espalhá-la, no entanto, quem deu o primeiro sopro de vida foi o grande deus Olodumaré, assim nasceu a humanidade. Nesta pesquisa, a Educação se apresentou com um barro em disputa a ser moldado constantemente, a depender da espécie da galinha, recebendo sopros de vida variados. A Educação se comportou como uma categoria teórica e prática fundamental de disputa de poder. Ela se intersecciona e movimenta os marcadores sociais raça, gênero, sexualidade, região, religião e geração. Assim, faz-se importante voltar a pergunta inicial: a quem essas parcerias interessam, para o público ou para o privado?

Axé! 


\section{Referências}

AKOTIRENE, Carla. O que é interseccionalidade?. Belo Horizonte: Letramento; Justificando, 2018.

ALMEIDA, Heloisa Buarque de. Mulher em campo: reflexões sobre a experiência etnográfica. In: ALMEIDA, Heloisa Buarque de; COSTA, Rosely Gome; RAMÍREZ, Martha Celia; e SOUZA Érica Renata de (Org.). Gênero em Matizes. Bragança Paulista: Editora da Universidade São Francisco, pp. 49-80, 2002.

ALMEIDA, Silvio Luiz. O que é racismo estrutural?. Belo Horizonte: Letramento, 2018. AMARAL, Sharyse Piroupo. Um pé calçado e outro no chão: liberdade e escravidão em Sergipe. Cotinguiba, 1860-1900. EDUFBA- Editora Diário Oficial, 2012 Salvador/Aracaju.

ANDREWS, George Reid. Democracia racial brasileira: 1900-1990: um contraponto americano. Estudos Avançados, nº 11, p. 95-115, 1997.

ARRUTI, José Maurício. Mocambo: antropologia e história do processo de formação quilombola. Bauru, SP: Edusc, 2006.

BAHBA, Homi. O local da Cultura. Belo Horizonte: Editora UFMG, 2007

BARTH, Frederik. Os grupos étnicos e suas fronteiras. In: O guru, o iniciador e outras variações antropológicas. Rio de Janeiro, Contracapa, 2000.

BERTONCELO, Edison. As Classes na Teoria Sociológica Contemporânea. BIB, 67, p. 25-49, 2009.

BEZERRA, Felte. Etnias Sergipanas (Estudos Sergipanos, IV). $1^{\text {a }}$ Reedição. Aracaju: Gráfica Editorial J. Andrade, 1984.

BOAS, Franz. Antropologia cultural. (Org. Celso Castro). Rio de Janeiro: Jorge Zahar, 2004.

BONFIM, Wellington de Jesus. Identidade, memória e narrativas na dança de São Gonçalo do povoado da Mussuca (SE). Dissertação (Mestrado em Antropologia Social), Universidade do Rio Grande do Norte, Natal, 2006.

BOURDIEU, Pierre. Economia das Trocas Simbólicas. Ed. Perspectiva: São Paulo, 1974. Social space and symbolic space. Sociological Theory, v. 7, n. 1, 14-25, 1989.

BOURDIEU, Pierre; WACQUANT, Loic. Prefácio: Sobre as Artimanhas da Razão Imperialista. In: BOURDIEU, Pierre. Escritos de Educação. Petrópolis, Editora Vozes, 1998.

CARNEIRO, Sueli. Gênero, Raça e Ascensão. Revista Estudos Feministas, São Paulo, v. 3, p. 301-596, 1995.

CARNEIRO DA CUNHA, Manuela. Cultura com aspas e outros ensaios. São Paulo: Cosac Naify, 2009.

CARONE, Iray. A distância subjetiva entre as classes, de acordo com Aléxis de Tocqueville. In: CARONE, Iray; BENTO. Maria Aparecida Silva (Org.) Psicologia social do racismo. Petrópolis: Vozes, 2002

CERNEA, Michael. Involuntary resettlement in development projects: policy guidelines in Word Bank financed projects. World Bank technical paper, no. WTP 80. Washington DC ; World Bank, 1988.

Social integration and population displacement: the contribution of social Science. UNESCO: Blackwefl Publishers, 1995a.

Social Organization and Development Anthropology. Human Organization, v. 54 , n. 3 , p. $340-52,1995$ b. 
COELHO, Fernando de Souza. Reformas e Inovações na Gestão Pública no Brasil Contemporâneo. In: José Mario Brasiliense Carneiro; Humberto Dantas. (Org.). Parceria Social Público-Privado - textos de referência. São Paulo: Oficina Municipal, 2012, p. 1-376.

COLARES, Marília Lília I. S.; PACÍFICO, Juracy Machado; ESTRELA, George Queiroga (Org.). Gestão Escolar: enfrentando os desafios cotidianos em escolas públicas. Curitiba: Editora CRV, 2009.

COMAROFF, Jean; COMAROFF, John L. Ethnicity, Inc. Chicago: University of Chicago Press, 2009.

COSTA, Áurea de Carvalho. Quatro questões sobre a noção de competência na formação de professores: o caso brasileiro. Revista de Educação, 12(2), p. 95-106, 2004.

COSTA, Sérgio. Muito além da diferença: (im)possibilidades de uma teoria social póscolonial.

Disponível

em: http://www.npms.ufsc.br/programas/poscolonialismo\%20Costa.pdf , 2005.

CRENSHAW, Kimberlé. Mapping the Margins: Intersectionality, Identity Politics, and Violence against Women of Color. Stanford Law Review. v. 32, n. 6, p. 12411299, 1991. (Tradução no prelo).

CRUZ, Mariléia dos Santos. A educação dos negros na sociedade escravista do Maranhão Provincial. Outros Tempos, v. 6, p. 110-126, 2009.

DANTAS, Beatriz Góis. Dança de São Gonçalo. Cadernos de Folclore, n. 14. Rio de Janeiro, MEC, 1976.

Vovó Nagô e papai branco: usos e abusos da África no Brasil. Rio de Janeiro. Graal, 1988.

DAS, Veena; POOLE, Deborah (Ogs.). Anthropology in the margins of the state. Santa Fe, New Mexico: School of American Research Press, 2004 (330p.).

. El Estado y sus márgens. Revista Académica de Relaciones Internacionales, núm. 8 junio de 2008 .

DAVIS, Angela. Mulheres, raça e classe. São Paulo: Ed. Boitempo, 2016.

DIAS, Isabel Simões. Competências em educação: conceito e significado pedagógico. Revista Semestral da Associação Brasileira de Psicologia Escolar e Educacional, v. 14, n. 1, p. 73-78, 2010.

DOMINGUES, José Maurício. Global Modernization, 'Coloniality' and a Critical Sociology for Comtemporary Latin America. Theory Culture Society, n. 16, 2009.

ESCOBAR, Arturo. El desarrollo sostenible: diálogos de discursos. Ecologia política, 1995.

ERIKSEN, Thomas Hylland. Ethnic identity, national identity and intergroup conflict: the significance of personal experiences. In: ASHMORE; JUSSIM; e WILDER (Orgs.). Social identity, intergroup conflict, and conflict reduction. Oxford, Oxford University Press, 2001. p. 1-4;12-17.

FALCÃO, Christiane Rocha. Reis de Congo na festa de Santa Cruz: Dança de São Gonzalo da Mussuca e suas influências afro. Congresso da Alaic. São Leopoldo, 2006.

FANON, Frantz Pele negra, máscaras brancas. $2^{\circ}$ ed. (trad. de Renato da Silveira). Salvador: EDUFBA, 2008 [1952].

FIGUEIREDO, Ângela; PINHO, Osmundo Araújo. Idéias Fora do Lugar e o Lugar do Negro nas Ciências Sociais Brasileiras. Estudos Afro-Asiáticos, Ano 24, nº 1, p. 189-210, 2002.

FORMAN, Shepard. Camponeses: sua participação no Brasil. Rio de Janeiro: Centro Edelstein de Pesquisas Sociais, 2009 [1979].

FOUCAULT, Michel. Vigiar e punir. Petrópolis: Vozes, 1977. 
GEERTZ, Clifford. A interpretação das culturas. Rio de Janeiro: Editora Guanabara Koogan, 1989.

GILROY, Paul. O Atlântico Negro: Modernidade e dupla consciência, São Paulo, Rio de Janeiro, 34/Universidade Cândido Mendes - Centro de Estudos Afro-Asiáticos, 2001. 2007.

GONZALEZ, Lélia. O movimento negro na última década. In: GONZALEZ, Lélia \& HASENBALG, Carlos. Lugar de negro. Rio de Janeiro: Marco Zero, 1982, p. 0966.

Racismo e sexismo na cultura brasileira. Ciências Sociais Hoje, São Paulo, ANPOCS, p. 223-244, 1984.

Mulher Negra. Afrodiáspora, v. 3, n. 6/7, p. 94-104, 1985.

. Por um feminismo afrolatinoamericano. Caderno de Formação Política do Círculo Palmarino, n. 1, Batalha de Ideias, Brasil, 2011[1988].

GUIMARÃES, Antônio Sérgio. Sociologia e natureza: classes, raças e sexos. Seminário internacional: Trabalho, cuidado e políticas sociais. Sessão "Intersecção de múltiplas desigualdades: gênero, raça e classe", 2014.

HALL, Stuart. Quem Precisa de Identidade? In: SILVA, Tomaz Tadeu (org.). Identidade e diferença. Petrópolis, Vozes, 2000.

. A identidade cultural na pós-modernidade. Rio de Janeiro, DP\&A, 2001.

. Da diáspora. Identidades e mediações culturais. São Paulo, Humanitas, 2003.

HARAWAY, Donna. Situated knowledges: The Science question in feminism and the privilege of partial perspective. Feminism Studies, vol. 14, n. 3, 1988.

HENARE, Amiria; HOLBRAAD, Martin; e WASTELL, Sari (Orgs.). Thinking through things. Theorising artefacts ethnographically, Routledge, Londres e Nova York, 2007.

HOFBAUER, Andreas. Entre olhares antropológicos e perspectivas dos estudos culturais e pós-coloniais: consensos e dissensos no trato das diferenças. Antropolítica (UFF), v.27, p.99 - 130, 2009.

Cultura, diferença e (des)igualdade. Contemporânea, n.1, p. 69-102, 2011.

. Dominação e contrapoder. O candomblé no fogo cruzado entre construções e desconstruções de diferença e significado. Revista Brasileira de Ciência Política, v.5, p.37-79, 2011.

IPEA (Instituto de Pesquisa Econômica Aplicada). Retrato das desigualdades de gênero e raça. $4^{\text {a }}$ ed. - Brasília: IPEA, 2011.

KUHN, Thomas. A estrutura das revoluções científicas. São Paulo: Perspectiva, 1996.

LANDIM, Leilah. A invenção das ONGS: do serviço invisível a profissão impossível. Rio de Janeiro, tese (Doutorado em Antropologia), Museu Nacional, UFRJ, 1993.

LEINER. Piero C. A formação do estado numa perspectiva antropológica. In: LIMA, Antonio Carlos de Souza (Org.). Gestar e gerir: estudos para uma antropologia da administração pública no Brasil. Rio de Janeiro, Relume-Dumará, 2002.

LEITE, José Roberto. Pintores Negros do oitocentos. Edição. Emanoel Araújo. São Paulo: MWF-IFK, 1988.

LEITE, Salvador Antonio Oliveira. As TIC na Gestão da Educação Básica: Um estudo de caso na percepção dos educadores. Porto, dissertação de mestrado, Universidade Fernando Pessoa, 2018.

LIBÂNEO, José Carlos; Oliveira, João Ferreira de; e TOSCHI, Mirza Seabra. Educação escolar: políticas, estrutura e organização. São Paulo: Cortez, 2012. 
LIPSKY, Michael. Street-level bureaucracy: dilemas of the individual in public services. Nova York: Russel Sage Foundation, 1980.

LOPES, Ana Mônica Henriques. Neocolonialismo na África. Sankofa. Ano IV, n. 8, 2011.

LOTTA, Gabriela. O papel das burocracias do nível da rua na implementação de políticas públicas: entre o controle e a discricionariedade. In: FARIA, C. A. (Org.). Implementação de Políticas Públicas. Teoria e Prática. Belo Horizonte: Editora PUCMINAS, 2012.

LOURO, Guacira L. Gênero, história e educação: construção e desconstrução. Educação \& Realidade, Porto Alegre, v.20, n. 2, 1995.

LUTZ, Catherine e WHITE, Geoffrey. The Anthropology of Emotions. Annual Review of Anthropology, 15, pp. 405-436, 1986.

MARTINS, Erika Moreira. Todos Pela Educação: como os empresários estão determinando a política educacional brasileira. Campinas, dissertação (Mestrado em Educação), Unicamp, 2013.

. Todos pela educação? Como os empresários estão determinando a política educacional brasileira. Rio de Janeiro, Editora Lamparina, 2016.

. Estratégia e incidência empresarial na atual política educacional brasileira: $\mathrm{O}$ caso do movimento Todos pela Educação. Revista Portuguesa de Educação, vol. 31, n. 1, 2018.

MARX, Karl. Classes, Cap. LII. O Capital, Livro III. Rio de Janeiro: Editora Civilização Brasileira, 1974. O 18 Brumário de Luis Bonaparte. São Paulo: Editora Abril, 1970.

McCLINTOCK, Anne. Couro Imperial: Raça, Gênero e Sexualidade no Embate Colonial. Campinas: Editora da Unicamp, 2010.

MIGNOLO, Walter e TLOSTANOVA, Madina. Global Coloniality and the Decolonial Option. Kult 6. Special Issue: Epistemologies of Transformation: The Latin American Decolonial Option and its Ramifications. Department of Culture and Identity, Roskilde University, 2009.

MOUTINHO, Laura. Diferenças e desigualdades negociadas: raça, sexualidade e gênero em produções acadêmicas recentes. Cadernos Pagu, n.42, p.201-248, 2014.

MOTT, Luiz. Sergipe del rey: população economia e sociedade. Aracaju: Fundesc, 1986.

MUCCHIELLI, Laurent. Sociologie versus anthropologie raciale. L'engagement décisive des durkheimiens dans le contexte 'fin de siècle'. Gradhiva, 21, 1997.

MUNANGA, Kabengele. Negritude - Usos e sentidos. Belo Horizonte: Autêntica, 2009.

N'KRUMAH, Kwame. Neocolonialismo: Último Estágio do Imperialismo. Rio de Janeiro: Civilização Brasileira, 1967.

NUNES, Maria Thetis. Horácio Hora: o esquecido pintor romântico sergipano. Revista acadêmica Sergipana, $\mathrm{n}^{\circ}$ Especial, p.222-226, 1999.

OLIVEIRA, João Paulo Gama. Vestígios "dos jovens anos escolares" de uma intelectual brasileira: itinerários da aluna Maria Thetis Nunes. Revista de História e Historiografia da Educação, Curitiba, v. 1, n. 1, p. 174-192, 2017

PALMEIRA, Moacir. Política e Tempo: nota exploratória. In: PEIRANO, Mariza. (Org.). O Dito e o Feito: Ensaio de Antropologia dos Rituais. Rio de Janeiro: Relume Dumará, 2001, p. 171-177.

PAOLI, Maria Célia. Empresas e responsabilidade social: os enredamentos da cidadania no Brasil. In: SANTOS, Boaventura de Souza (Org.). Democratizar a democracia: os caminhos da democracia participativa. $2^{\mathrm{a}}$ ed. Rio de Janeiro: Civilização Brasileira, 2003. 
PARO, Vitor Henrique. Formação de Gestores escolares: a atualidade de José Querino Ribeiro. Educação e Sociedade, v. 30, n. 107, p. 453-467, 2009. . Administração Escolar: introdução crítica. 17. ed. São Paulo: Cortez, 2012. . Gestão escolar, democracia e qualidade do ensino. São Paulo: Ática, 2007.

PASSOS, Lucas Santos. Tombamentos de templos religiosos em Laranjeiras/Sergipe. Aracaju, dissertação (mestrado em sociologia), Universidade Federal de Sergipe, 2015.

PÉRICO, Ana Elisa Périco e REBELATTO, Daisy Aparecida do Nascimento. Desafios das parcerias público-privadas (PPPs). Revista de Administração Pública, v. 39, p. 1031-1052, 2005.

PINHO, Osmundo. A Antropologia no Espelho da Raça. Anais da $26^{a}$ Reunião Brasileira de Antropologia. Porto Seguro, BA, ABA, 2008.

PINHO, Osmundo de Araújo e FIGUEIREDO, Angela. Idéias fora do lugar e o lugar do negro nas ciências sociais brasileiras. Estudos Afro-Asiáticos, vol.24, n.1, pp.189210, 2002.

QUIJANO, Aníbal. Colonialidad del poder, eurocentrismo y América Latina. In: LANDER, Edgardo (Org.). La colonialidad del saber: eurocentrismo y ciencias sociales. Perspectivas latino-americanas. Buenos Aires: CLACSO/UNESCO, 2000.

REZENDE, Flávia. As novas tecnologias na prática pedagógica sob a perspectiva construtivista. Ensaio Pesquisa em Educação em Ciências, v. 2, n. 1, p. 75-98, 2008

RIOS, Flávia e SOTERO, Edilza. Gênero em perspectiva interseccional. Plural, Revista do Programa de Pós-Graduação em Sociologia da USP, São Paulo, v. 26, n. 1, pp.1-10, 2019.

RODRIGUES, Noeli. ONGs: A sociedade civil e o papel do Estado. Curitiba: UFPR, 2013.

ROSE, Nikolas. Inventiveness in politcs. Economy and Society, vol.28, n³, 1999.

SAID. Edward. Orientalismo: o Oriente como invenção do Ocidente. Trad. Tomás Rosa Bueno. São Paulo: Companhia das Letras, 1978.

SAHLINS, Marshall. Metáforas históricas e realidades míticas: estrutura nos primórdios da história do reino das ilhas Sandwich. Rio de Janeiro: Jorge Zahar Editor, 2008 [1981].

SANTOS, Mesalas Ferreira. Performance e escárnio na festa do Lambe Sujo de Laranjeiras. Aracaju, dissertação (Mestrado em Sociologia), Núcleo de PósGraduação em Ciências Sociais, Universidade Federal de Sergipe, 2009.

SANTOS, Jaqueline Lima. Negro, jovem e hip hopper: história, narrativa e identidade em Sorocaba. Marília, dissertação de mestrado, Universidade Estadual Paulista, 2011.

SILVA, Claudio Gomes da. A Importância do Uso das TICS na Educação. Revista Científica Multidisciplinar Núcleo do Conhecimento, ano 3, ed. 8, vol. 16, p. 4959, 2018.

SILVA, Eunice Maria Ferreira. Gestão Escolar: novas abordagens, novos olhares e novas propostas. Pesquisa realizada para a dissertação de mestrado. Intranet. UFSJ. Disponível

em: http://intranet.ufsj.edu.br/rep_sysweb/File/vertentes/Vertentes_29/eunice_silva.p $\underline{\mathrm{d}}$

SOUZĀ, Valéria Alves de. Os tambores das 'yabás': raça, sexualidade, gênero e cultura no Bloco Afro Ilú Obá De Min. São Paulo, dissertação de mestrado, Universidade de São Paulo, 2014. 
SPIVAK, Gayatri Chakravorty. In Other Worlds: Essays in Cultural Politics. Londres: Methuen, 1989.

STRATHERN, Marilyn. Partial connections. Oxford: Altamira Press, 2004.

SUBRINHO, José Modesto Passos. Reordenamento do trabalho: trabalho escravo e trabalho livre no nordeste açucareiro - Sergipe 1850/1930. Aracaju: FUCAJU, 2000.

TEIXEIRA, Analba Brazão; SILVA, Ariana Mara da; e FIGUEIREDO, Angela. Um diálogo decolonial na colonial cidade de Cachoeira/BA: entrevista com Ochy Curiel. Cadernos de Gênero e Diversidade, v. 03, n. 04, p. 106-120, 2017.

THOMAZ, Omar; NASCIMENTO, Sebastião. Raça e Nação. In: SANSONE, Lívio e PINHO, Osmundo Araújo (Orgs.). Raça: novas perspectivas antropológicas. Salvador: Associação Brasileira de Antropologia, EDUFBA, 2008.

VIANNA, Anna Morawska. Os Enleios da Tarrafa: etnografia de uma parceria transnacional entre ONGs através de emaranhados institucionais de combate à pobreza. São Paulo, tese (Doutorado em Antropologia), USP, 2010.

VIEIRA, Eloisa Maia e VIDAL, Sofia Lerche. Perfil e formação de gestores escolares no Brasil. Dialogia, São Paulo, n. 19, p. 47-66, 2014.

WARE, Vron (Org.). Branquidade: identidade branca e multiculturalismo. Rio de Janeiro: Garamond, 2004.

WEBER, Max. "Grupos Étnicos”. In: Economia e Sociedade. São Paulo: Imprensa Oficial, 1994. 